\title{
2. SITE 447: EAST SIDE OF THE WEST PHILIPPINE BASIN
}

\author{
Shipboard Scientific Party ${ }^{1}$
}

\section{HOLES 447, 447A}

Date occupied: 6 February 1978

Date departed: 12 February 1978

Time on hole (hrs): 1.5 (Hole 447), 137.5 (Hole 447A)

Position: $18^{\circ} 00.88^{\prime} \mathrm{N} ; 133^{\circ} 17.37^{\prime} \mathrm{E}$

Water depth (sea level; corrected m, echo-sounding): 6022

Water depth (rig floor; corrected m, echo-sounding): 6032

Penetration (m): 296.5

Number of cores: 1 (Hole 447), 37 (Hole 447A)

Total length of cored section (m): 9 (Hole 447), 296.5 (Hole 447A)

Total core recovered (m): 0.4 (Hole 447), 155 (Hole 447A)

Core recovery (\%): 4.4 (Hole 447), 52.3 (Hole 447A)

Oldest sediment cored:

Depth sub-bottom (m): 113

Nature: Volcaniclastic breccia

Age: Middle Oligocene (NP 24)

Measured velocity $(\mathrm{km} / \mathrm{s}): 3.6-4.6$

Basement:

Depth sub-bottom (m): 113

Nature: Tholeiitic basalts

Velocity range $(\mathrm{km} / \mathrm{s}): 4.7-5.2$

Principal results: Site 447 is located on the eastern side of the West Philippine Basin between the Central Basin Ridge and the PalauKyushu Ridge. Two holes were drilled at the site, the first of which was abandoned when only a core-catcher sample was recovered from the first core. The sample contained manganese nodules, fragments of manganiferous crust, and traces of brown pelagic clay. Ichthyoliths, tentatively ascribed to the early Miocene, were also present. A second hole (447A) was successfully drilled at the site to a sub-bottom depth of 296.5 meters; the upper 113 meters consist of sediments and the lower 182.5 meters consist of extrusive phyric and aphyric tholeiitic basalts.

The sedimentary section is divisible into five units. From the top downward they are: Unit $1,37.5$ meters of brown pelagic clay possibly deposited in the early Miocene; Unit 2, 9.5 meters of calcareous pelagic clay deposited in the late middle to early late Oligocene; Unit 3, 38 meters of polymictic conglomerate and breccia; Unit 4, 2.1 meters of altered variegated fine tuff; and Unit 5, 25.9

1Loren Kroenke (Co-Chief Scientist), Hawaii Institute of Geophysics, University of Hawai, Honolulu, Hawaii; Robert Scott (Co-Chief Scientist), Department of Geology, Texas A\&M University, College Station, Texas; Kathy Balshaw, Department of Geology, Rice University, Houston, Texas; Simon Brassell, School of Chemistry, University of Bristol, Bristol, United Kingdom; Pierre Chotin, Laboratoire de Géologie Structurale, Université Pierre et Marie Curie, Paris, France (now at: Département de Géologie, Université Mohammed V, Rabat, Morocco); Mary E. Heiman, Stratigraphy Laboratory, Mobil Oil Company, Dallas, Texas (now at: F and H Biostratigraphic Associates, Laramie, Wyoming): Teruaki Dallas, Texas (now at: F and H Blostratigraphic Associates, Laramie, Wyoming); Teruak Ishi, Ocean Research Fnstitute, University of Tokyo, Tokyo, Japan, Barbara H. Keating, Hawaii Institute of Geophysics, University of Hawail, Honolulu, Hawaii; Erlend Martini, Geologisch-Paläontologisches Institut, Johann-Wolfgang-Goethe-Universität, Frankfurt am Main, Federal Republic of Germany; David P. Mattey, Department of Geology, Bedford College, University of London, London, United Kingdom (now at: Department of Geological Sciences, University of Birmingham, Birmingham, England); Kelvin Rodolfo, Department of Geological Sciences, University of Illinois, Chicago, Illinois; Renzo Sartori, Laboratorio di Geologia Marina del C.N.R., Bologna, Italy; Fritz Theyer, Hawaii Institute of Geophysics, University of Hawaii, Honolulu, Hawaii; John L. Uther, Deep Sea Drilling Project, Scripps Instituity of Geology, Georgian Academy of Sciences, Tbilisi, U.S.S.R. (now at: V. I. Vernadsky Inst. of Geochem. and Analyt. Chem., U.S.S.R. Acad. of Sciences, Vorobyewskoe chaussee 47A. 117334 Moscow, U.S.S.R.). meters which can be further divided into two volcaniclastic breccia sub-units separated by a tuff sub-unit. Nannofossils throughout the interval encompassed by Units 3 through 5 indicate an age range of early late to middle Oligocene. The upper part of the sedimentary sequence was deposited well below the carbonate compensation depth (CCD), whereas the lower part was deposited close to the CCD. Because Site 447 is situated on the sedimentary apron west of the Palau-Kyushu Ridge, tuffs within the lower 47 meters of the middle Oligocene sedimentary sequence probably were derived from that source. Within volcaniclastic breccias, however, basaltic clasts occur with increasing size, abundance, and freshness down-section and appear to have been derived locally from the igneous basement.

The underlying tholeiitic basalts consist of six major petrographic units, several of which are subdivisible into individual cooling units that commonly have pillow lava tops and massive flow bottoms. From the top downward the units are: Unit 6, 18.5 meters of plagioclase-phyric flows and pillow lavas; Unit 7, 9.5 meters of plagioclase-phyric pillow lavas; Unit 8, 44.0 meters of plagioclase-clinopyroxene-olivine-phyric pillow lavas (the bases of massive flows of these lavas are doleritic); Unit 9, a 9.0-meter aphyric to olivine-spinel-phyric flow; Unit 10, 15.0 meters of olivine-plagioclase-clinopyroxene-phyric pillow lavas; Unit 11, 87.5 meters of plagioclase-olivine-spinel-phyric pillow lavas. The lower 14.5 meters of Unit 11 contain plagioclase and spinel megacrysts and anorthositic cumulate xenoliths.

\section{BACKGROUND AND OBJECTIVES}

Because both the age and origin of the West Philippine Basin are in question, the principal objectives at Site 447 were to drill through a thin sediment cover as far as possible into basement to seek evidence regarding the age and origin of this marginal basin.

Magnetic lineation patterns are often the best indicators of the timing of ocean-crust generation. However, within marginal basins, identification of magnetic lineation patterns and correlation of these lineations with the geomagnetic reversal time scale has proven to be difficult, even though the general age of these basins is commonly indicated by data from nearby DSDP sites and evidence from adjacent islands.

Previous deep-sea drilling suggests, for example, that the West Philippine Basin (Fig. 1) was formed during the early Tertiary. Two holes had previously been drilled at Site 290 in the West Philippine Basin during DSDP Leg 31 . The deeper of the two, Hole 290, was positioned at $17^{\circ} 44.85^{\prime} \mathrm{N}, 133^{\circ} 28.08^{\prime} \mathrm{E}$, about $35 \mathrm{~km}$ south and east of Site 447 (Fig. 1). The units as described down-hole in Hole 290 include 90 meters of Quaternary to upper Pliocene brown silt-rich clays; 49 meters of upper Oligocene nannofossil ooze (the juxtaposition of these two units suggests subsidence of the West Philippine Basin below the CCD); 80 meters of lower Oligocene or upper Eocene volcanic silts; and an upper Eocene or lower Oligocene basal volcanic breccia. The two basal volcanic units are thought to have been derived from the Palau-Kyushu Ridge. The basal 


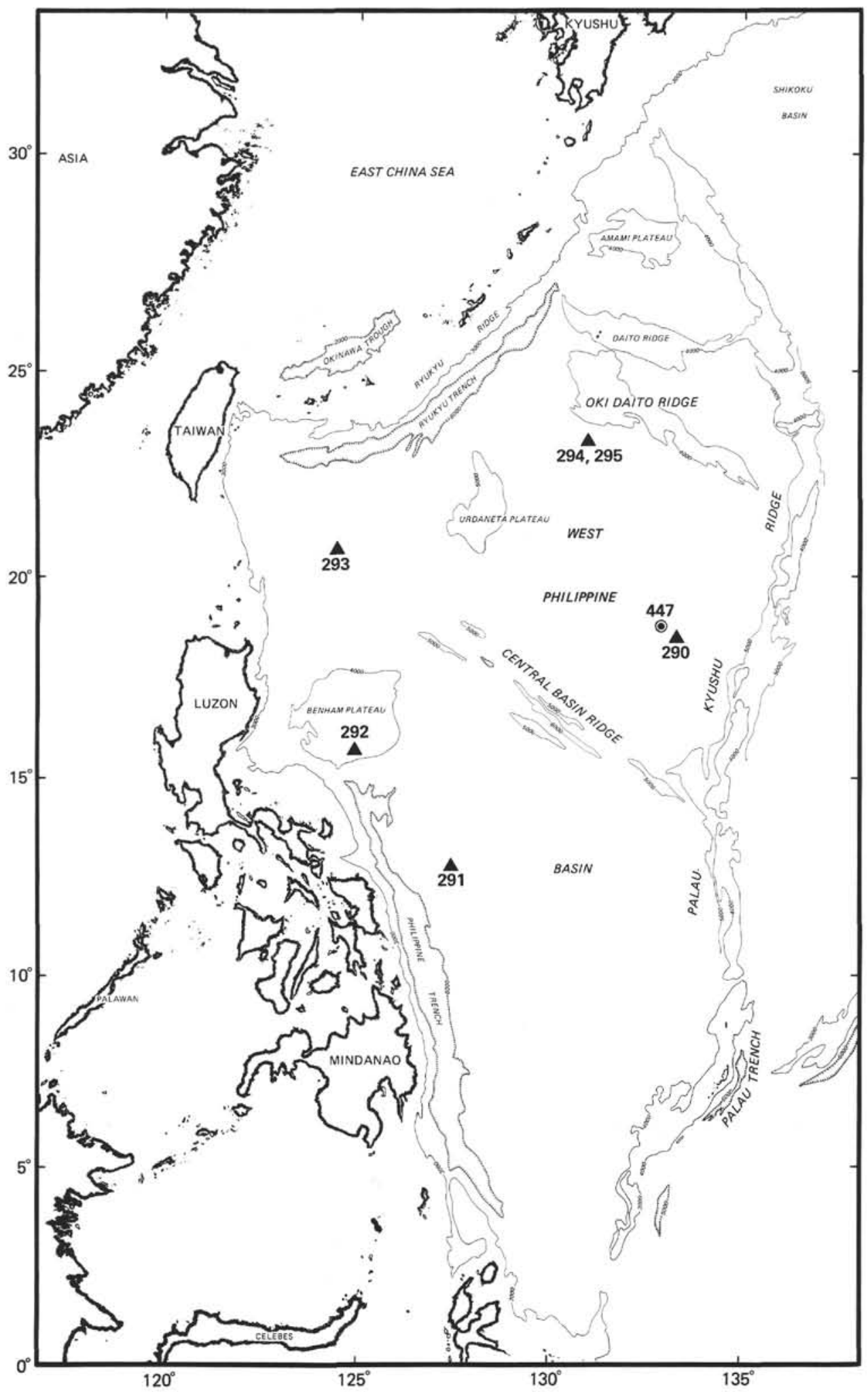

Figure 1. Location of Site 447 and geographic features of the West Philippine Basin and vicinity that are discussed in the text. (The concentric point locates Site 447 and the triangles locate other DSDP Sites.)

breccia, possibly formed by slumping from a local topographic high, contains basalt clasts in a nannofossil-bearing matrix that indicates a minimum age of late Eocene for the basement, which itself was not actually reached (Karig, 1975).
In accord with these data, the results of recent magnetic surveys also suggest an early Tertiary origin, probably by spreading from the Central Basin Ridge. Louden (1976) has mapped west-northwest trending magnetic lineations south of the Central Basin Ridge, 
which he identified as Anomalies 18 through $21(\sim-45$ to -52 m.y.). Magnetic lineations trending westnorthwest recently mapped north of the Central Basin Ridge (Watts et al., 1977, Fig. 6), appear oblique to the strike of the Palau-Kyushu Ridge and the active Mariana arc-trench system (Fig. 1).

Site surveys undertaken by Lamont-Doherty Geological Observatory (L-DGO) and Scripps Institution of Oceanography (SIO) indicate that water depths average about 6000 meters in the Site 447 area. A general increase in water depth, a lessening of basement relief, and a slight increase in sediment thickness in a northnortheast direction suggest an increase of basement age in this direction (Fig. 2). The magnetic lineations reported by Watts et al. (1977) are parallel to bathymetric trends striking west-northwest; such magnetic and bathymetric orientations suggest spreading in a northnortheast direction, perhaps from a spreading center to the south-southwest. L-DGO Site Survey magnetic profiles also clearly parallel the trend of local topography (Fig. 3).

Because depth to basement in the West Philippine Basin is much greater than to the accreted sea floor of similar age in the main ocean basins, it has been suggested that the geomagnetic data might be interpreted better in terms of the Mesozoic geomagnetic time scale (Ben-Avraham et al., 1972). Thus, the lineations previously mapped both north and south of the Central Basin Ridge could be variously interpreted as representing either one or both limbs of a Mesozoic or Early Tertiary spreading system.

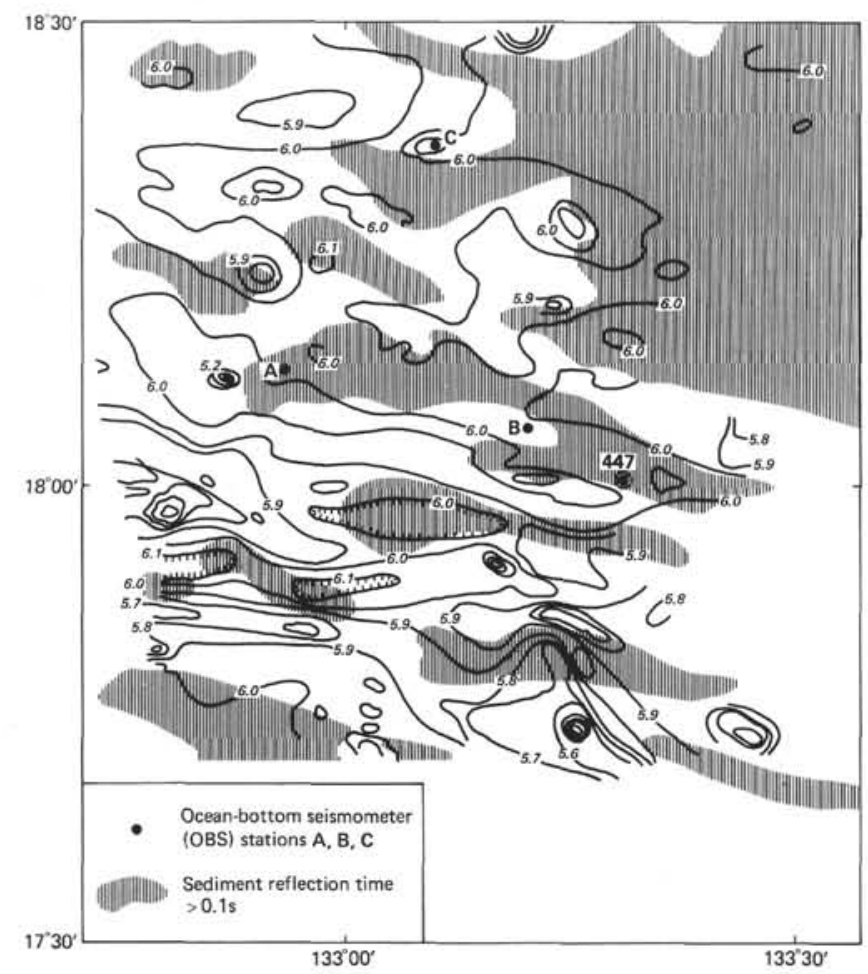

Figure 2. Bathymetry and sediment thickness near Site 447 (L-DGO Site Survey data). (Water depth is contoured in intervals of 0.1 $\mathrm{km}$; shaded sections indicate areas underlain by greater than $0.1 \mathrm{~s}$ reflection time of sediment.)

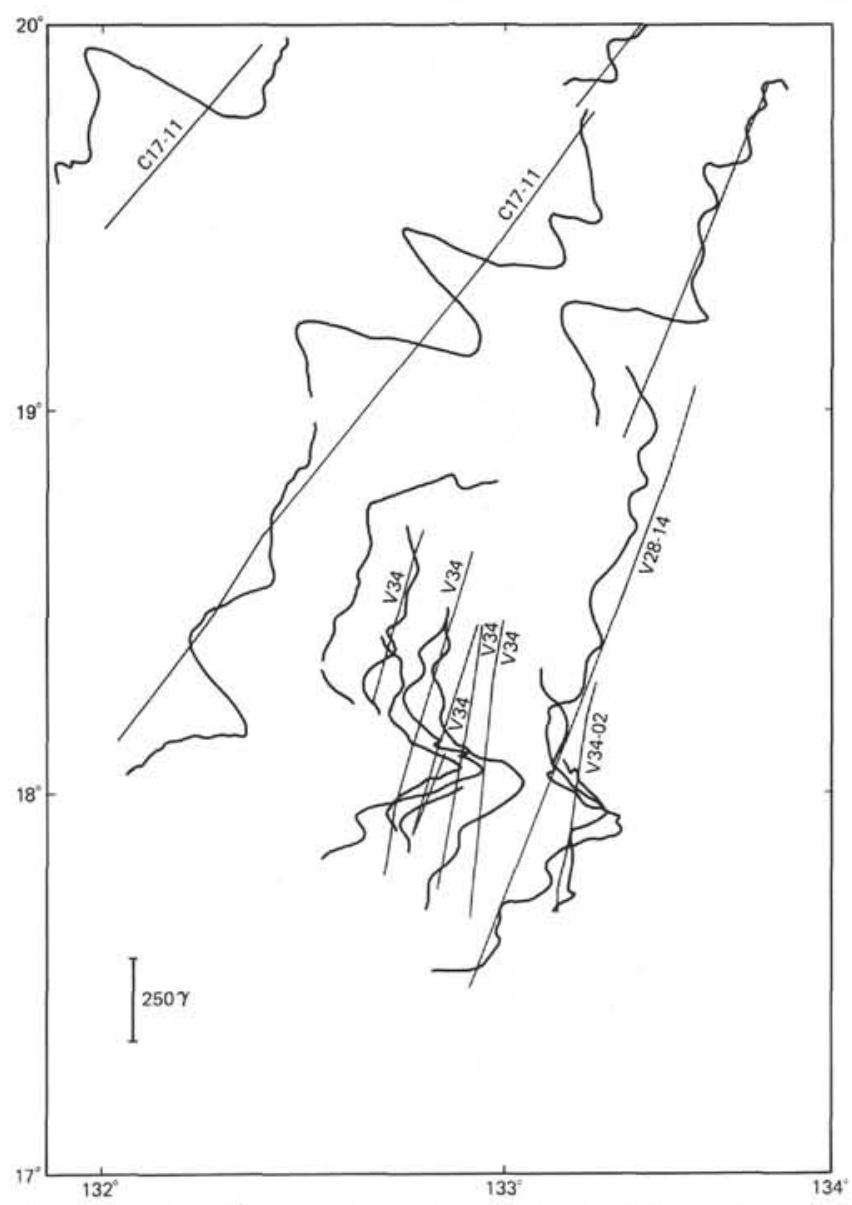

Figure 3. Magnetic-anomaly profiles in the vicinity of Site 447 (L-DGO Site Survey data).

To complicate matters further, reconnaissance seismic-refraction studies in the Philippine Sea have indicated that most of the basin floor is underlain by a $3.5-\mathrm{km} / \mathrm{s}$ acoustic basement layer, possibly Early Tertiary flows, capping a much older oceanic crust. The numerous intrusive basaltic units encountered in the sedimentary column at Holes $442-444$ of the Northern Philippine transect (Leg 58, Klein, Kobayashi et al., in press) emphasize the need for caution in making indirect interpretations of basement age within marginal basins.

Site 447 , therefore, was intentionally located in the eastern part of the West Philippine Basin where the $3.5-\mathrm{km} / \mathrm{s}$ capping layer is either very thin or absent. L-DGO Site Survey data also confirm the absence of the $3.5-\mathrm{km} / \mathrm{s}$ basement layer at this site (Langseth and Mrozowski, this volume).

In order to encounter fewer drilling difficulties, Site 447 was also located farther from the volcanic-debris source of the Palau-Kyushu Ridge than was Site 290. The seismic-reflection profile recorded during the L-DGO 447 Site Survey (Fig. 4) shows an irregular sediment thickness that exceeds 0.3 -s reflection time in structural depressions in a block-faulted basement.

Taking all these factors into account, a single-bit hole was planned to penetrate the 200 meters of surface sediment (Fig. 2) and to drill as far as possible into the $5.2-\mathrm{km} / \mathrm{s}$ basement to test for entrapment of old crust of unknown origin. 


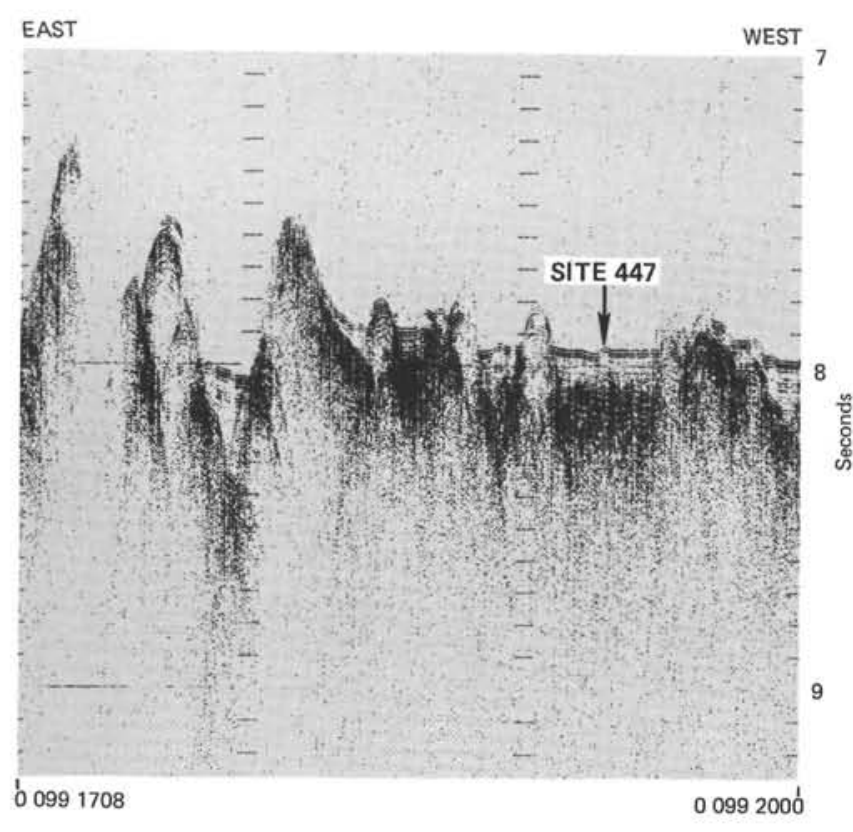

Figure 4. Seismic-reflection profile recorded during preliminary site surveys for Site 447 (L-DGO Site Survey data: Vema cruise 34-02, JD 099, 1977; note the profile is from east [left] to west [right]).

\section{OPERATIONS}

At 0818 Local Time (L), 3 February 1978, the Glomar Challenger departed Naha, Okinawa bound for Site 447 in the West Philippine Sea. After leaving the harbor entrance and crossing the 200-meter contour, the Challenger slowed to deploy the underway geophysical equipment. At $1045 \mathrm{~L}$, with all equipment streamed, speed was increased to 9.2 knots and a course of $147^{\circ}$ was set for Site 447.

Situated in the eastern sector of the West Philippine Basin, Site 447 had been selected on the basis of geophysical site survey data (L-DGO) collected earlier on the Vema and the Conrad. Three days out of Okinawa the Challenger approached the site from the northwest, on a course of $127^{\circ}$ (Fig. 5). The reflection profile being taken by the Challenger so closely resembled the profile obtained earlier by the Vema that a decision was made to drop the beacon on the initial pass over the site. At 0948, 6 February a $13.5-\mathrm{kHz}$ doublelife beacon was dropped as the ship crossed Site 447.

Between $1130 \mathrm{~L}$ and $1315 \mathrm{~L}$, underway survey equipment was retrieved and the vessel was positioned over the site. A standard F94CK drill bit was selected and a standard bottom-hole assembly was rigged. From 1315 L, 6 February, to 0145 L, 7 February, the bottom-hole assembly and drill string were run to the sea floor, strapping the pipe in the process. Sea floor was felt at 6021 meters below sea level compared to 6022 meters determined by the $12-\mathrm{kHz}$ PDR. The hole was spudded in at $0145 \mathrm{~L}$, and a mud-line punch core was recovered. Because the core catcher was jammed with manganese nodules, only a trace of sediment was recovered. In order to resample the same interval, a new hole was begun, designated 447A.

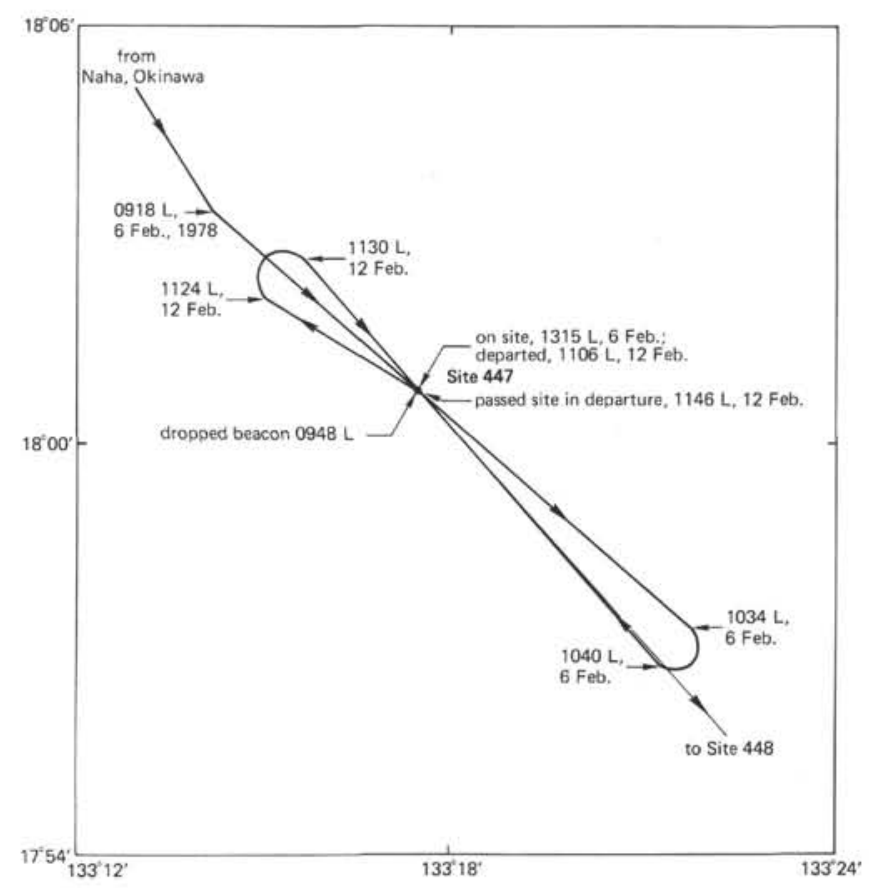

Figure 5. Track of the Glomar Challenger during approach and departure from Site 477. (The black circle marks the position of the beacon.)

After recovery of the punch core from Hole 447A, the core catchers of Cores 2 and 3 were fouled with the sand line protective coating, resulting in a lack of recovery in Core 2 and a low recovery in Core 3. A total of five cores were cut in soft sediment before more indurated sediments were encountered in Cores 6 through 11. In Core 12, the sediment was well indurated, and at the bottom of Core 13 basalt basement was recovered from 113 meters sub-bottom.

From 113.0 meters to 270.5 meters sub-bottom, 20 cores were cut in basalt (Cores 14 through 33). Between Cores 17 and 18 , the bit was briefly plugged, which necessitated pumping down the core barrel with the center bit attached in order to dislodge the obstruction. Torquing-up occurred and circulation was lost toward the end of cutting of Core 33. Little core was recovered, which was essentially jammed in the core catcher, and several sections were filled with coarse, sand-sized cuttings thought to have caved from above (which apparently caused the torquing-up and loss of circulation). After pulling out nine joints of pipe, circulation was recovered; the pipe was run back and the hole cleaned out to total depth and flushed with drilling mud.

Cores 34 to 36 were cut between 270.5 and 293.0 meters sub-bottom (Table 1). Progressive reduction of core diameter in Cores 35 and 36 indicated progressive bit failure, and after repeated torquing-up during the cutting of Core 37, drilling was terminated at 296.5 meters sub-bottom in tholeiitic basalt.

During the drilling operations, a short, wide-angle reflection sonobouy profile was obtained to aid in correlation of seismic-reflection profiles with the drilling 
Table 1. Coring summary, Holes 447 and 447A.

\begin{tabular}{|c|c|c|c|c|c|c|c|}
\hline $\begin{array}{l}\text { Core } \\
\text { No. }\end{array}$ & $\begin{array}{c}\text { Date } \\
\text { (February, } \\
\text { 1978) }\end{array}$ & $\begin{array}{l}\text { Local } \\
\text { Time } \\
\text { (L) }\end{array}$ & $\begin{array}{c}\text { Depth from } \\
\text { Drill Floor } \\
\text { (m; top-bottom) }\end{array}$ & $\begin{array}{c}\text { Depth below } \\
\text { Sea Floor } \\
\text { (m; top-bottom) }\end{array}$ & $\begin{array}{l}\text { Length } \\
\text { Cored } \\
\text { (m) }\end{array}$ & $\begin{array}{l}\text { Length } \\
\text { Recovered } \\
\text { (m) }\end{array}$ & $\begin{array}{c}\text { Recovery } \\
(\%)\end{array}$ \\
\hline \multicolumn{8}{|l|}{ Hole 447} \\
\hline 1 & 7 & 0305 & $6031.0-6040.0$ & $0.0-9.0$ & 9.0 & 0.4 & 4.4 \\
\hline \multicolumn{8}{|c|}{ Hole $447 \mathrm{~A}$} \\
\hline 1 & 7 & 0447 & $6031.0-6040.0$ & $0.0-9.0$ & 9.0 & 8.0 & 88.3 \\
\hline 2 & 7 & 0634 & $6040.0-6049.5$ & $9.0-18.5$ & 9.5 & 0.0 & 0.0 \\
\hline 3 & 7 & 0824 & $6049.5-6059.0$ & $18.5-28.0$ & 9.5 & 1.0 & 10.7 \\
\hline 4 & 7 & 1009 & $6059.0-6068.5$ & $28.0-37.5$ & 9.5 & 6.7 & 70.2 \\
\hline 5 & 7 & 1204 & $6068.5-6078.0$ & $37.0-47.5$ & 9.5 & 9.6 & 104.0 \\
\hline 6 & 7 & 1405 & $6078.0-6087.5$ & $47.0-56.5$ & 9.5 & 9.7 & 101.7 \\
\hline 7 & 7 & 1625 & $6087.5-6097.0$ & $56.0-66.0$ & 9.5 & 9.6 & 100.8 \\
\hline 8 & 7 & 1823 & $6097.0-6106.5$ & $66.0-75.5$ & 9.5 & 1.8 & 19.5 \\
\hline 9 & 7 & 2025 & $6106.5-6116.0$ & $75.5-85.0$ & 9.5 & 3.2 & 33.3 \\
\hline 10 & 7 & 2210 & $6116.0-6125.5$ & $85.0-94.5$ & 9.5 & 3.1 & 32.9 \\
\hline 11 & 8 & 0008 & $6125.5-6129.0$ & $94.5-98.0$ & 3.5 & 0.9 & 25.7 \\
\hline 12 & 8 & 0225 & $6129.0-6135.0$ & $98.0-104.0$ & 6.0 & 3.5 & 58.3 \\
\hline 13 & 8 & 0512 & $6135.0-6144.0$ & $104.0-113.0$ & 9.0 & 0.8 & 8.9 \\
\hline 14 & 8 & 0750 & $6144.0-6153.0$ & $113.0-122.0$ & 9.0 & 4.6 & 51.1 \\
\hline 15 & 8 & 1052 & $6153.0-6162.0$ & $122.0-131.0$ & 9.0 & 4.4 & 48.9 \\
\hline 16 & 8 & 1404 & $6162.0-6171.0$ & $131.0-140.0$ & 9.0 & 1.9 & 21.2 \\
\hline 17 & 8 & 1652 & $6171.0-6180.0$ & $140.0-149.0$ & 9.0 & 3.9 & 43.3 \\
\hline 18 & 8 & 2340 & $6180.0-6183.0$ & $149.0-152.0$ & 3.0 & 3.0 & 100.0 \\
\hline 19 & 9 & 0244 & $6183.0-6189.0$ & $152.0-158.0$ & 6.0 & 3.2 & 53.3 \\
\hline 20 & 9 & 0605 & $6189.0-6198.0$ & $158.0-167.0$ & 9.0 & 4.0 & 44.4 \\
\hline 21 & 9 & 0928 & $6198.0-6207.0$ & $167.0-176.0$ & 9.0 & 5.9 & 65.6 \\
\hline 22 & 9 & 1218 & $6207.0-6211.0$ & $176.0-180.0$ & 4.0 & 3.3 & 82.5 \\
\hline 23 & 9 & 1610 & $6211.0-6216.0$ & $180.0-185.0$ & 5.0 & 4.4 & 88.0 \\
\hline 24 & 9 & 2014 & $6216.0-6222.0$ & $185.0-191.0$ & 6.0 & 3.3 & 55.0 \\
\hline 25 & 10 & 0155 & $6222.5-6229.5$ & $191.0-198.5$ & 7.5 & 4.7 & 62.7 \\
\hline 26 & 10 & 0528 & $6229.5-6238.5$ & $198.5-207.5$ & 9.0 & 5.1 & 56.7 \\
\hline 27 & 10 & 0845 & $6238.5-6247.5$ & $207.5-216.5$ & 9.0 & 2.8 & 31.1 \\
\hline 28 & 10 & 1214 & $6247.5-6256.5$ & $216.5-225.5$ & 9.0 & 3.4 & 37.8 \\
\hline 29 & 10 & 1622 & $6256.5-6265.5$ & $225.5-234.5$ & 9.0 & 5.8 & 64.4 \\
\hline 30 & 10 & 2020 & $6265.5-6274.5$ & $234.5-243.5$ & 9.0 & 7.0 & 77.8 \\
\hline 31 & 10 & 2345 & $2674.5-6283.5$ & $243.5-252.5$ & 9.0 & 4.5 & 50.0 \\
\hline 32 & 11 & 0338 & $6283.5-6292.5$ & $252.5-261.5$ & 9.0 & 4.2 & 46.7 \\
\hline 33 & 11 & 0658 & $6292.5-6301.5$ & $261.5-270.5$ & 9.0 & 0.3 & 3.3 \\
\hline 34 & 11 & 1124 & $6301.5-6306.0$ & $270.5-275.0$ & 4.5 & 2.7 & 60.0 \\
\hline 35 & 11 & 1509 & $6306.0-6315.0$ & $275.0-284.0$ & 9.0 & 8.0 & 88.9 \\
\hline 36 & 11 & 2022 & $6315.0-6324.0$ & $284.0-293.0$ & 9.0 & 5.7 & 63.3 \\
\hline 37 & 12 & 1015 & $6324.0-6327.5$ & $293.0-296.5$ & 3.5 & 0.9 & 25.7 \\
\hline Total & & & & & 296.5 & 155.0 & 52.3 \\
\hline
\end{tabular}

results. At 1103 L, 12 February 1978, the ship departed Site 447 , and a short seismic-reflection survey was completed across the beacon en route to Site 448 .

\section{SEDIMENTARY LITHOLOGY}

Lying above the basaltic basement at Site 447 are 113 meters of lower Miocene to middle Oligocene sedimentary and volcaniclastic rocks separable into five lithologically distinct units (see Fig. 6).

Unit 1 is 37.5 meters thick and consists of pelagic clay. Dark brown in Core 1, Section 1, the clay grades downward to dark reddish brown in Core 3 . The clay appears as alternating brown and yellowish red layers 40 to $95 \mathrm{~cm}$ thick in Core 4 . These color changes probably are caused by variations in the content of micronodules and amorphous iron-oxide aggregates, neither component of which exceeds $10 \%$ in smear slides. The zeolite content systematically increases down-core, from traces at the top to $10 \%$ at the base of the unit. The entire core is structureless except for rare, scattered lumps and patches of slightly more indurated, yellowish, presumably less iron-rich material a few $\mathrm{mm}$ across. Unit 1 is almost devoid of fossils except for fish teeth, which indicate that the unit is lower Miocene.

Unit 2, 9.5 meters thick, occurs only in Core 5; contacts with overlying and underlying units were not recovered. The unit is a calcareous pelagic clay, dark yellow-brown at the top and grading down-core through yellow-brown to light yellow-brown at its base. This color change probably reflects a subtle decrease in micronodule and amorphous iron content. The sediment in Section 1 contains 2\% micronodules and 3\% amorphous iron oxides; these constituents decrease downhole to $1 \%$ and a trace, respectively, in Section 6. 


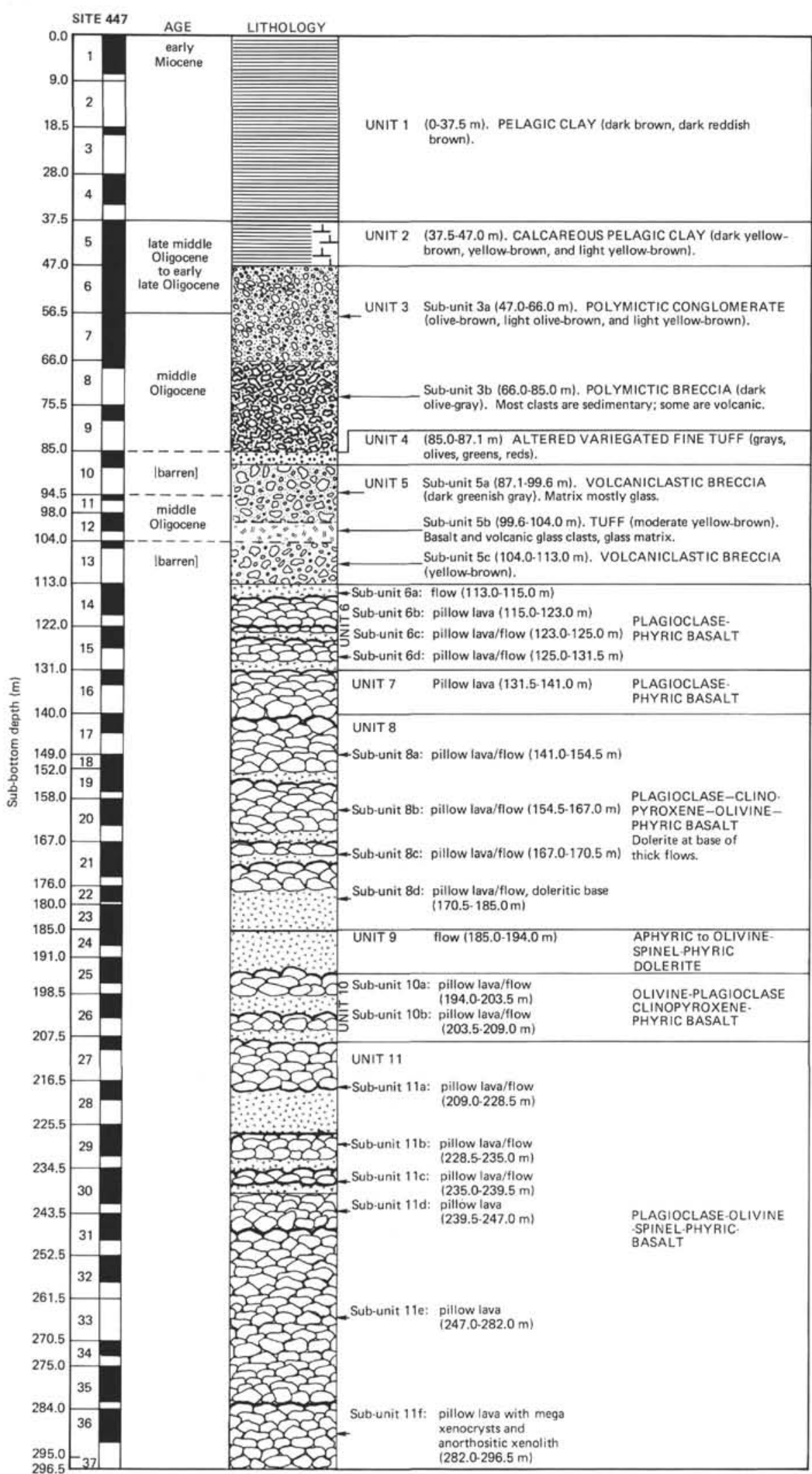

Figure 6. Lithology, age, and core recovery at Site 447. (Heavier lines on pillow tops indicate top of a pillow lava unit or sub-unit. Pillowed massive flows are abbreviated as "pillow lava/flow." Dashed lines in the age column indicate borders of barren intervals. Core recovery is indicated by the solid symbol. Lithologic symbols are summarized in the Introduction [this volume].) 
However, the basal 3 meters of the unit are marked at 10 - to $20-\mathrm{cm}$ intervals by $0.5-$ to $1-\mathrm{cm}$ round, dark blebs containing about $10 \%$ micronodules and about $40 \%$ amorphous iron oxides.

Unit 3, 38 meters thick, includes a polymictic conglomerate and a polymictic breccia recovered from Cores 6 through 9. As in Unit 2, the upper and lower contacts were not recovered.

Sub-unit 3a, the uppermost 19 meters of Unit 3, is a polymictic conglomerate, olive-brown in color, grading down through light olive-brown to light yellowish brown. The matrix and some of the clasts are composed of semilithified calcareous pelagic clay. Clasts of pumice and brown, deeply weathered basalt also occur. The clasts are predominantly rounded and increase in average size down-core from 0.2 to $0.5 \mathrm{~cm}$ to about 1 to 2 $\mathrm{cm}$. The clast:matrix ratio varies from about $1: 7$ in the top 2 meters of the sub-unit to about 1:1 in the rest of the core. Compositionally, the matrix is dominated by clay minerals with small amounts of volcanic glass and fine carbonate. Deeply etched coccoliths are present throughout the sub-unit; nannofossils are less common in its lower part and most of the carbonate is recrystallized.

In the upper part of the sub-unit, drilling disturbance was moderate to intense, disaggregating most of the conglomerate except for a few 2-cm-thick pieces. In the lower part of the sub-unit, where an increase in lithification occurs, some of the conglomerate consists of coherent pieces up to $10 \mathrm{~cm}$ thick. The coherent pieces contain manganiferous patches and dendrites, and the tops of some of the pieces are marked by thin manganiferous films. There is therefore some suggestion that drilling deformation was controlled partly by lithification processes involving manganiferous sediments.

Sub-unit 3b, the lowermost 19 meters of Unit 3, is a polymictic breccia recovered from Cores 8 and 9 . Its contacts with overlying and underlying units were not recovered; its top is placed at the top of Core 8 and its bottom in the core catcher of Core 9. The breccia is dark olive-gray to dark greenish gray. The clast:matrix ratio ranges between about $3: 2$ and $3: 1$, tending to increase down-core. Clasts range in size from 0.1 to $5.5 \mathrm{~cm}$, averaging about $1 \mathrm{~cm}$ in diameter. Mudstone fragments dominate the clasts, although volcanic clasts become more important down-core. The sedimentary clasts are moderately rounded to well rounded, whereas the igneous fragments typically are more angular. The matrix is a calcareous pelagic clay.

Unit 4 is the top 2.1 meters of Core 10 . The lower contact with Unit 5 is sharp. Unit 4 is an altered fine tuff, variegated in shades of gray, brown, olive, olivegray, and grayish green, in layers 8 to $40 \mathrm{~cm}$ thick. Light and dark mottling varies from slight to intense. The sediment contains smectite, phillipsite, and potassium feldspar. The alteration paragenesis is dealt with by Sartori and Tomadin (this volume).

Unit 5, 25.9 meters thick (Cores 10 through 13), is divided into three sub-units: in the upper part, Sub-unit $5 \mathrm{a}$ is a grayish green volcaniclastic breccia with a tuff layer near its top; in the middle, Sub-unit $5 \mathrm{~b}$ is a light yellowish brown tuff; and in the lower part, Sub-unit 5c is a light yellowish brown volcaniclastic breccia.

Sub-unit 5a, 12.5 meters thick, has a greenish black tuff layer $59 \mathrm{~cm}$ thick near its top. Elsewhere the subunit consists of angular clasts of fresh and weathered basalt in a matrix of amorphous, very fine volcanic glass with minor recrystallized carbonate and coccolith remnants. The clast:matrix ratio is about 3:1. This sub-unit has a disturbed contact with Sub-unit $5 \mathrm{~b}$.

Sub-unit 5 b consists of 4.4 meters of tuff. Near the top, the tuff contains mostly very coarse sand-size clasts, grading down-core through coarse sand into coarse and medium sand at the base of the sub-unit. The clasts are angular, irregularly shaped, and rarely larger than $2 \mathrm{~mm}$ in diameter, although fragments as coarse as $7 \mathrm{~cm}$ are present. Almost all the clasts are of volcanic origin; weathered reddish brown basalt comprises from 40 to $75 \%$ of the clasts, volcanic glass and pumice from 25 to $60 \%$, and vesicular basalt with zeolite-filled amygdules typically about $10 \%$. In places the clasts display moderate sorting, and the platy or prismatic grains are oriented parallel to bedding. The clast:matrix ratio is about $7: 3$. The matrix is mainly clay- and silt-sized glass fragments. Rare ghosts of coccoliths and other carbonate grains comprise less than $5 \%$ of the matrix. About $10 \%$ is authigenic zeolite, which outlines cavities with acicular, radiating clear crystals and is also rarely associated with carbonate particles.

Sub-unit 5c, 9.0 meters thick, is a light yellow-brown volcaniclastic breccia containing massive and zeolitized vesicular basalt fragments, mostly consisting of reddish brown weathered spherulitic glass. The clasts are angular and irregularly shaped, with average diameters of about $1 \mathrm{~cm}$, although some fragments are larger than the 6.6-cm diameter of the core. The clast:matrix ratio is about $3: 1$; the matrix is a carbonate-rich volcanic glass with some clay. Approximately 5\% of the intergranular spaces are filled with clear zeolites mainly bordering the margins of some glass clasts.

The contact between basal Sub-unit $5 \mathrm{c}$ and the underlying basalt was sampled in the core catcher of Core 13 . Unfortunately, during recovery of the core most of the core-catcher contents fell out on deck, so the pieces may be out of sequence. As reconstructed, the upper $10 \mathrm{~cm}$ of the core catcher contain a plagioclase-phyric basalt cobble; the next $7 \mathrm{~cm}$ (the volcaniclastic breccia of Subunit $5 \mathrm{c}$ and the lower part of the core catcher) contain basalt from igneous basement.

Variations in the texture of the sedimentary units recovered from Hole 447A provide clues to the tectonic history of the site. Unit 5 is primarily a clastic suite of volcanic lithologies. Sub-unit $5 \mathrm{c}$, overlying the basalt, is essentially a basal conglomerate, except that the clasts are predominantly angular rather than rounded. Subunit $5 \mathrm{~b}$ and the lower part of Sub-unit $5 \mathrm{a}$ constitute an upward-coarsening trend indicating a tectonic rise of volcanic provenance during the middle Oligocene. Culmination of this coarsening trend is represented by the sample from the core catcher of Core 11. Subsequently, another middle Oligocene pulse of tectonism resulted in both uplift of the site as well as deposition of the brec- 
cias of Unit 3. This time, however, provenance consisted of both volcanic and sedimentary carbonate rocks. With advancing time, the breccia clasts became dominated almost entirely by chalk lithologies. Culmination of this second tectonic event reasonably can be assumed to have occurred before the site had finished accumulating its coarse clastics. Because the tuffs of Unit 4 may have been deposited over a very short period by a sudden pulse of volcanic activity from the PalauKyushu Ridge, deposition of coarse clastics of Units 5 and 3 may be related to the same tectonic events, interrupted briefly by an influx of fresh volcaniclastic debris. In either case, the uplifted site accumulated nannofossil ooze above the CCD in the late Oligocene before subsiding through the CCD in the early Miocene, after which subsidence continued until modern depths were attained. During this latter subsidence the uppermost 37.5 meters of pelagic clay were deposited (Unit 1). The lack of volcanic components in this unit is notable and indicates that the Palau-Kyushu Ridge has remained volcanically inactive since the early Miocene.

\section{BIOSTRATIGRAPHY}

In Hole 447A 113 meters of sediments, believed to be a continuous sequence, were cored (Fig. 6). However, the continuity of the sequence in Unit 1 can be debated; this is discussed in detail in the Accumulation Rates section of this report. Lithologic Unit $1(0-37.5 \mathrm{~m})$, a noncalcareous, dark brown to dark reddish brown, pelagic clay, contains only ichthyoliths (Samples 447-1,CC and 447A-1,CC). On the basis of these fossils, this particular level is tentatively assigned to the lower Miocene. Lithologic Unit $2(37.5-47.0 \mathrm{~m})$ consists of calcareous pelagic clay that grades downward into coarser sediments of Units 3 to $5(47.0-113.0 \mathrm{~m})$, including polymictic conglomerates and volcaniclastic breccias with interbedded tuff. With the exception of Core 10 (85.0-94.5 m), nannofossils occur throughout this sequence and indicate an interval from the middle Oligocene to the early late Oligocene. Radiolarians and foraminifers are extremely rare, the former giving no clues as to age and the latter indicating the Eocene-Oligocene (displaced ?) in Core 7. Diatoms and silicoflagellates were not found.

The upper part of the sedimentary column in Hole 447A is closely similar to that at Hole 290 , cored during DSDP Leg 31. In both holes unfossiliferous brown zeolitic clays, which are twice as thick at Hole 290 as at Hole 447A, are underlain by calcareous sediments with the calcareous nannoplankton Zone NP 24 (Sphenolithus distentus Zone) at the top, grading downward into Zone NP 23 (S. predistentus Zone). Core 12 of Hole 447A may actually be equivalent to part of Core 6 in Hole 290. At Hole 290 the oldest fossil occurrence seems to indicate the late Eocene or early Oligocene, but there is a discrepancy between the nannoplankton and radiolarian age determinations (Karig, Ingle, et al., 1975). In Hole 447A, displaced lower Oligocene nannofossils are noted throughout the middle Oligocene section, suggesting a continuous input of eroded material from lower Oligocene sediments. This might well apply also to Hole 290, where continuous mixing with upper-
Eocene radiolarian clays displaced from a nearby source is suspected.

\section{Foraminifers}

All samples from Site 447 are barren or nearly barren of foraminifers. One specimen of the benthic species, Cassidulina subglobosa, and one arenaceous tube-like foraminifer were observed in the core-catcher material from Core 6. In Sample 447A-7,CC three poorly preserved planktonic specimens (Pseudohastigerina micra? [1], Globigerina spp. [2]) were found. The presence of $P$. micra (if in place) suggests that this is an Oligocene or Eocene sample. The core-catcher material from Core 11 contained one specimen of Globigerina sp.

\section{Calcareous Nannoplankton}

Lithologic Unit 1 (Cores 1-4) is barren of calcareous nannoplankton, but calcareous nannofossils are present from the top of Core 5 down to Core 12 (37.5-104.0 m), with the exception of Core $10(85.0-94.5 \mathrm{~m})$. The assemblages in most cases are poorly preserved and the specimens heavily etched. In Cores 5 and 6 Sphenolithus ciperoensis is present together with $S$. distentus, $S$. predistentus, Coccolithus abisectus, and Dictyococcites dictyodus, indicating the Oligocene calcareous nannoplankton Zone NP 24 (S. distentus Zone). The same assemblage is present in Cores 7 to 12 , except for $S$. ciperoensis, and consequently is placed in calcareous nannoplankton Zone NP 23 (S. predistentus Zone). $C$. abisectus, which first occurs at about the same level as $S$. ciperoensis elsewhere, and which is taken as a substitute species for defining the base of Zone NP 24 in high latitude areas (Müller, 1970), was found in all samples down to Sample 12,CC. A similar occurrence of these two species was noted by Ellis (1975) at the nearby Site 290 as well as at Site 296 . The use of $C$. abisectus as a substitute species has to be reinvestigated. In several samples, with maxima in Samples 447A-5, CC and $-9, \mathrm{CC}$, Reticulofenestra umbilica as well as rare Cyclococcolithus formosus and Braarudosphaera bigelowi, probably displaced from lower Oligocene deposits, have been found. This indicates continuous erosion in an adjacent area during this time.

\section{Radiolarians}

Radiolarians are extremely rare in the sedimentary units recovered from Hole 447A. The few specimens (all are Cenozoic spumellarians) found in the core catchers of Cores 6,7 , and 9 are either nondiagnostic or too fragmentary for positive identification.

\section{Ichthyoliths}

Because of the lack of traditional planktonic fossils in the brown pelagic clays of Unit 1 of Holes 447 and $447 \mathrm{~A}$, we made an on-board attempt to determine ages by means of fish teeth, which were present in quantities sufficient for study in the core catchers of Cores 1 of Holes 447 and 447A. Owing to the lack of expertise of the shipboard scientists, the identifications were preliminary; nevertheless, using the compilation of Doyle et al. (1974), we identified specimens of ten different 
subtypes. Five of the forms range throughout much of the Cenozoic, but three forms range from the Eocene to the Miocene (Curved triangle pointed margin, Flexed triangle 102-112, Flexed narrow triangle 120-128), and the other two (Triangle short wing and Triangle medium wing), restrict the ages even further, as they have not been recorded in earlier reports (Dengler et al., 1975; Doyle et al., 1974) in sediments younger than the early Miocene.

Given the present state of knowledge of fish debris, the stratigraphic resolution that can be achieved using such data is certainly less precise than that possible with more traditional fossils. On the basis of the above findings, however, it is reasonable to suggest an age of at least the early Miocene for the bottoms of Cores 1 of Holes 447 and 447A.

\section{PALEOENVIRONMENT}

Core 1 of Hole 447, and Cores 1 through 4 of Hole $447 \mathrm{~A}$ are barren of calcareous nannofossils and foraminifers, suggesting deposition possibly near the present-day water depth of about 6000 meters and certainly below the CCD. The CCD in the Philippine Sea today seems to lie somewhere between 4000 and 4500 meters (Ujiie, 1975). Poorly preserved calcareous nannofossils are present from the top of Core 5 to Core 12 of Hole 447A. Rare, often poorly preserved foraminifers occur sporadically throughout this interval (noted in Cores 6, 7, and 11). The data thus indicate that Cores 5 to 12 were deposited at depths shallower than Cores 1 through 4 , probably near to the CCD.

\section{ACCUMULATION RATES}

Five depositional units (ranging from nearly barren brown pelagic clay to coarse volcaniclastic breccia) were identified in the sedimentary sequence recovered from Hole 447A above the basalt. In such a section, markedly different accumulation rates are to be expected, but unfortunately, close estimates of these rates cannot be provided because of indefinite biostratigraphic boundaries or datum planes. At 9.0 meters sub-bottom in Hole 447A the sediments may be as old as the early Miocene (based on ichthyoliths). In contrast, the lower 104.0 meters of sediment range in age, at most, from about 29 to $33 \mathrm{~m} . \mathrm{y}$.

The typical pelagic brown clay of Unit 1 must have accumulated at a fairly uniform, slow rate. A minimum accumulation rate for Unit 1 is $2 \mathrm{~m} / \mathrm{m}$.y., assuming that it is as old as $15 \mathrm{~m} . \mathrm{y}$. at a horizon 9.0 meters down-hole (Core 1,CC) and that Unit 2 (37.5-47.0 m) ends at about $29 \mathrm{~m}$.y. (early late Oligocene). This sedimentation rate is in accordance with rates registered elsewhere for such barren, deep-sea clays. Yet extrapolation of this rate to the surface of the sediment layer leads to untenable results. Thus if a complete middle Miocene to Quaternary section was indeed recovered in Core 1 (Hole $447 \mathrm{~A}$ ), then a considerably lower rate is required to account for these 9.0 meters. Alternatively, parts of this younger section must be missing or the Miocene fish teeth in the core catcher of Core 1 are reworked. If the latter is true, and if a complete lower upper Oligocene to
Quaternary sequence was recovered in Cores 1 through 4 , an average sediment accumulation rate of $1.3 \mathrm{~m} / \mathrm{m} . \mathrm{y}$. results, which is still comparable to rates determined in other areas of similar depositional environments.

Whereas Unit 1 is at least of sufficient uniformity to warrant one average sedimentation rate, the other six units - all deposited during a probable maximum of 4 m.y.-definitely cannot have been accumulated at the same sedimentation rate. It is probably safe to assume that most if not virtually all of these $4 \mathrm{~m}$.y. may have elapsed during deposition of the 9.5-meter-thick Unit 2, because it represents typical, slow, deep-sea sedimentation. The tuffs of Unit 4 probably represent a rapid deposition of volcanic pyroclastic debris, interrupting coarse sedimentation of Units 5 and 3, which presumably typify rapid accumulations caused by a sudden influx of sediment resulting from tectonic events.

\section{REGIONAL STRATIGRAPHIC SYNTHESIS}

Four DSDP holes have been drilled in the Western Philippine Basin between the Oki Daito Ridge, to the north, and the Central Basin Ridge, to the south (Fig. 1). Three of the holes, 290,294 , and 295 , were drilled on Leg 31 (Karig, Ingle, et al., 1975); the fourth, 447, was drilled on the present Leg 59 (Fig. 7).

At Hole 447, we penetrated 113 meters of sediment before encountering basaltic basement. The first 25.9 meters of sedimentation consist of middle Oligocene volcaniclastic breccia interbedded with tuff. The volcaniclastic breccia is overlain by a variegated altered fine tuff, in turn overlain by a middle Oligocene polymictic breccia and a middle to lower upper Oligocene polymictic conglomerate, which are situated below a calcareous pelagic clay (totaling $49.6 \mathrm{~m}$ ). Following deposition of the calcareous pelagic clay, carbonate sedimentation ceased, and 37.5 meters of dark-brown pelagic clay were deposited, in part, during the early Miocene.

The altered fine tuff, the upper 7.4 meters of the volcaniclastic breccia, and the basal 9 meters of breccia above the basaltic basement are barren of microfossils. The breccia and tuff between these barren zones contain nannofossils of the middle Oligocene (see Fig. 7).

The presence of two sedimentary layers containing nannofossils separated by a barren sub-unit cannot be attributed to either tectonic uplifts through the CCD or fluctuations of the CCD itself, because nearly instantaneous influxes of ashes or volcaniclastic breccias may so dilute the fossil record that the sediments appear barren. Also the pore waters created during low-temperature reactions of sea water with fresh igneous rocks may cause solution of calcareous fossils.

At Site 290, approximately $35 \mathrm{~km}$ to the south and east of Site 447, 255 meters of sediment were penetrated but basement was not contacted. The oldest sediment at this site is a lower-Oligocene or upper Eocene volcanic conglomerate $(33 \mathrm{~m})$, very similar to the volcaniclastic breccia at Site 447 . Overlying the conglomerate are 83 meters of lower-Oligocene ash-rich variegated clay, similar to the unit of altered tuff found at Site 447 . The succeeding 49 meters are upper-Oligocene ash- and radi- 

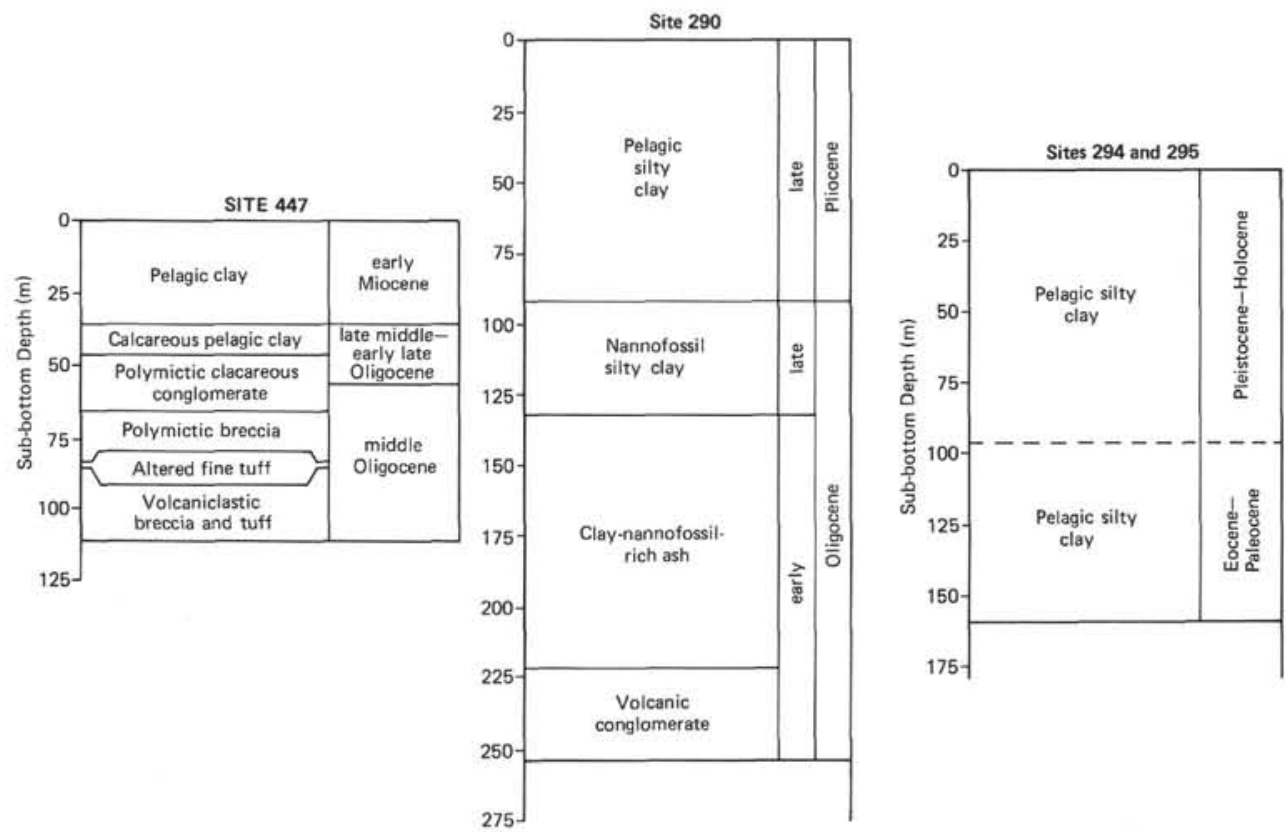

Figure 7. Summaries of stratigraphic sections encountered at Sites 447, 290, 294, and 295 within the northern part of the West Philippine Basin. (Thicknesses are in meters sub-bottom.)

olarian-bearing silty clay that is rich in nannofossils. Carbonate sediments are absent above this level, which is overlain by 90 meters of upper-Pliocene dark yellowbrown silty clay.

The combined Holes 294 and 295 had a maximum penetration of 158 meters in sediment. Initial deposition at this site consists of approximately 60.5 meters of dark reddish brown (ferruginous) silty clay with a minimum age of Paleocene-Eocene. This is capped by approximately 97.5 meters of Pleistocene-Holocene moderate brown silty clay.

The sediments from Sites 290 and 447 can be expected to reflect similar depositional histories because they are both situated on the sedimentary apron of the western flank of the Palau-Kyushu Ridge in nearly identical water depths (Site 447 at $6019 \mathrm{~m}$, Site 290 at $6071 \mathrm{~m}$ ). However, their distance from the ridge varies; Site 447 is slightly farther from the provenance (PalauKyushu Ridge) than is Site 290 . A volcaniclastic breccia was deposited over both locations in the early to middle Oligocene. Both sites were near or above the CCD through the late Oligocene; after this period, sedimentation changed from carbonates to pelagic clay (early Miocene at Site 447) and to pelagic silty clay (late Pliocene at Site 290) when both sites fell below the CCD.

The appearance of lower Oligocene volcaniclastic breccias at Sites 290 and 447 may be related to tectonic events associated with the initiation of subduction along the Palau-Kyushu Ridge. Vertical movement associated with subduction tectonics apparently persisted throughout the Oligocene, with the exception of minor fluctuations, maintaining the sites above the CCD. After this time the sites fell below the CCD, either because of subsidence of the back-arc region following cessation of subduction or normal basin subsidence with age. The lack of Miocene sediments at Site 290 could indicate nondeposition or erosion due either to bottom currents or local tectonic adjustments.

The Oki Daito Ridge is the primary provenance for Sites 294 and 295 sedimentation and is not affected by the same tectonic processes that controlled sedimentation at Sites 290 and 447 . Sites 294 and 295 remained below the CCD during their entire sedimentary history, accumulating pelagic clays and tephra. Their basal Eocene or Paleocene pelagic silty clay may represent the initial sediment type deposited at Sites 290 and 447 before disruption by tectonism.

\section{ORGANIC GEOCHEMISTRY}

Four gas shows observed in Site 447 cores (Sections $5-3,6-3,6-4$, and 7-4) were sampled and analyzed by procedures described in the Introduction (this volume). In each gas-chromatograph analysis, hydrocarbon bases were absent, although minor amounts of $\mathrm{CO}_{2}$ were detected. The absence of methane suggests that biogenic gaseous hydrocarbons have not been generated or preserved in significant quantities in this sedimentary environment and that the sediments themselves are of low thermal maturity and/or low in organic matter.

Twenty samples were investigated for organic carbon and nitrogen contents (see the Introduction to this volume for the procedures used). The results of these investigations are given in Table 2 and are plotted against depth in Figure 8. Only minor amounts of organic carbon were found in each of the sedimentary units, with mean values between 0.1 and 0.3 wt. $\%$ of the carbonate-free sediment. No depth trend is discernible within any of the lithologic units or the sedimentary sequence as a whole. These low values probably reflect 
Table 2. Organic carbon and nitrogen contents (after carbonate dissolution).

\begin{tabular}{|c|c|c|c|c|}
\hline $\begin{array}{l}\text { Lithologic Unit } \\
\text { or Sub-unit }\end{array}$ & $\begin{array}{c}\text { Sample } \\
\text { (intervals in } \mathrm{cm} \text { ) }\end{array}$ & $\begin{array}{l}\text { Organic } \\
\text { Carbon } \\
\text { (wt. \%) }\end{array}$ & $\begin{array}{l}\text { Nitrogen } \\
\text { (wt. \%) }\end{array}$ & $\begin{array}{c}\mathrm{C}: \mathrm{N} \\
\text { (atomic ratio) }\end{array}$ \\
\hline \multirow[t]{3}{*}{1} & \multirow[t]{3}{*}{$1-1,50-51$} & 0.13 & 0.017 & 8.9 \\
\hline & & 0.18 & 0.037 & 5.7 \\
\hline & & 0.15 & 0.028 & 6.3 \\
\hline \multirow[t]{3}{*}{1} & \multirow[t]{3}{*}{$1-1,51-52$} & 0.21 & 0.033 & 7.5 \\
\hline & & 0.16 & 0.031 & 6.1 \\
\hline & & 0.15 & 0.028 & 6.3 \\
\hline \multirow[t]{3}{*}{1} & \multirow[t]{3}{*}{$1-2,58-59$} & 0.25 & 0.032 & 9.1 \\
\hline & & 0.20 & 0.025 & 9.4 \\
\hline & & 0.20 & 0.030 & 7.8 \\
\hline \multirow[t]{3}{*}{1} & \multirow[t]{3}{*}{$1-3,50-51$} & 0.12 & 0.023 & 6.1 \\
\hline & & 0.12 & 0.023 & 6.1 \\
\hline & & 0.12 & 0.021 & 6.1 \\
\hline \multirow[t]{3}{*}{1} & \multirow[t]{3}{*}{$1-4,50-51$} & 0.10 & 0.020 & 5.9 \\
\hline & & 0.11 & 0.023 & 5.6 \\
\hline & & 0.10 & 0.015 & 7.8 \\
\hline \multirow[t]{3}{*}{1} & \multirow[t]{3}{*}{$1-5,50-51$} & 0.13 & 0.017 & 8.9 \\
\hline & & 0.17 & 0.024 & 8.3 \\
\hline & & 0.10 & 0.012 & 9.7 \\
\hline \multirow[t]{3}{*}{1} & \multirow[t]{3}{*}{$4-1,80-81$} & 0.12 & 0.027 & 5.1 \\
\hline & & 0.12 & 0.031 & 4.6 \\
\hline & & 0.13 & 0.031 & 4.9 \\
\hline \multirow[t]{3}{*}{1} & \multirow[t]{3}{*}{$4-2,68-69$} & 0.22 & 0.022 & 11.7 \\
\hline & & 0.25 & 0.024 & 11.7 \\
\hline & & 0.21 & 0.021 & 11.7 \\
\hline 1 & $4-3,73-74$ & 0.12 & 0.014 & 10.1 \\
\hline & & 0.11 & 0.017 & 7.6 \\
\hline & & 0.09 & 0.012 & 8.8 \\
\hline 1 & $4-4,51-52$ & 0.24 & 0.028 & 10.1 \\
\hline & & 0.26 & 0.031 & 9.8 \\
\hline & & 0.32 & 0.030 & 12.5 \\
\hline 1 & $4-5,46-47$ & 0.15 & 0.028 & 6.3 \\
\hline & & 0.16 & 0.027 & 6.9 \\
\hline & & 0.11 & 0.021 & 6.1 \\
\hline 2 & $5-2,48-49$ & 0.13 & 0.009 & 16.8 \\
\hline & & 0.15 & 0.012 & 14.6 \\
\hline & & 0.10 & 0.009 & 13.0 \\
\hline 2 & $5-3,64-65$ & 0.13 & 0.007 & 21.8 \\
\hline & & 0.13 & 0.008 & 19.1 \\
\hline & & 0.11 & 0.004 & 32.2 \\
\hline 2 & $5-5,33-34$ & 0.30 & 0.011 & 31.8 \\
\hline & & 0.28 & 0.017 & 19.2 \\
\hline & & 0.35 & 0.015 & 27.3 \\
\hline 2 & $5-5,34-35$ & 0.23 & 0.009 & 29.8 \\
\hline & & 0.20 & 0.007 & 33.5 \\
\hline & & 0.36 & 0.017 & 24.8 \\
\hline $3 a$ & $6-1,102-103$ & 0.11 & 0.005 & 25.7 \\
\hline & & 0.10 & 0.004 & 29.3 \\
\hline & & 0.15 & 0.007 & 19.2 \\
\hline $3 a$ & $7-3,138-139$ & 0.22 & 0.009 & 28.5 \\
\hline & & 0.15 & 0.005 & 35.1 \\
\hline & & 0.26 & 0.009 & 33.7 \\
\hline 4 & $10-1,28-31$ & 0.15 & 0.009 & 19.5 \\
\hline & & 0.16 & 0.010 & 18.7 \\
\hline & & 0.18 & 0.012 & 17.6 \\
\hline 4 & $10-2,31-33$ & 0.19 & 0.012 & 18.5 \\
\hline & & 0.15 & 0.012 & 14.6 \\
\hline & & 0.14 & 0.009 & 18.3 \\
\hline $5 a$ & $10-2,103-104$ & 0.25 & 0.007 & 41.8 \\
\hline & & 0.27 & 0.005 & 63.2 \\
\hline & & 0.18 & 0.004 & 52.7 \\
\hline
\end{tabular}

depositional conditions not conducive to the preservation of organic matter, such as oxic sedimentation and very low sediment accumulation rates, low productivity, or the sudden influx of volcanic debris. The nitrogen content of the pelagic clays of Unit 1 is higher (average $0.02 \%$ ) than those of the underlying calcareous pelagic clays, polymictic conglomerates and breccias, altered tuffs, and volcaniclastic breccias of Units 2, 3, 4, and 5 (average $0.01 \%$ ); this possibly reflects particle-size dif- ferences between these lithologies, because nitrogen is often concentrated in sediments of finer grain size. No uniform depth or diagenetic trend is observed for the $\mathrm{C}: \mathrm{N}$ ratio, whose mean values range from 5 to 52 .

Methods used for the 20 Rock Eval analyses are given in the Introduction (this volume). A summary of the results from the Rock Eval analyses is given in Table 3 . In qualitative terms two significant aspects regarding the state of the organic matter are shown by these analyses. First, anomalously large and irregular $S_{2}$ responses for samples from Units 1 and 4 , maximizing at $550^{\circ} \mathrm{C}$, cannot be attributed to highly mature organic matter or to pipe-dope contamination. In contrast, pipe-dope sampled from the Core 2 core-catcher sample has a broad $S_{1}$ peak and only a minor $S_{2}$ response. The appearance of similar anomalous $S_{2}$ peaks from analyses of analogous clay-rich lithologies at Sites 449 and 450 suggests that this $S_{2}$ response may arise from an as yet undefined interaction of unconsolidated clay with organic matter or from the clay itself. Second, the calcareous lithologies of Unit 1 and Sub-unit 3a give minimal $S_{1}$ and $S_{2}$ responses, indicating their lack of pyrolyzable organic matter. The high value of the $S_{3}$ peak for Unit 2 samples can be attributed to a contribution from inorganic $\mathrm{CO}_{2}$ not wholly excluded in such carbonate-rich lithologies.

The low amounts of organic carbon throughout Site 447 have limited the possible scope of the organic geochemical analyses. In addition, the presence of pipedope contamination in several cores (notably, the core catcher of Core 2) complicates interpretation of the hydrocarbon analysis.

\section{INORGANIC CHEMISTRY OF INTERSTITIAL WATER}

Samples for interstitial-water studies were taken from Sections $447 \mathrm{~A}-4-3$ and $-6-5$. Analytical techniques are given in the Introduction (this volume). Figure 9 presents data for inorganic parameters measured. (IAPSO standard and a surface sea-water sample are shown for comparison.) The collection and investigation of only two samples precluded detailed evaluation of diagenetic trends.

\section{IGNEOUS PETROGRAPHY}

Basaltic basement was encountered at a depth of 133 meters sub-bottom; after penetrating 183.5 meters of tholeiitic flows and pillow basalts, the maximum depth of 296.5 meters was reached. As a result of good drilling conditions ( $60 \%$ basalt core recovery), long uninterrupted cores were obtained. Observations of preserved glassy margins of pillows and flows made it possible to measure accurately flow and pillow dimensions. About 28 meters of middle-Oligocene volcaniclastic breccias and tuffs overlie this basement section. The basalts are subdivided into six major units based on hand-specimen lithology and thin-section petrography (see Fig. 6). Many of these major petrographic units are composed of several well-defined eruptive cooling units.

Three categories of eruptive cooling units exist: single lava flows composed of massive basalt, sometimes with ophitic textures in the center; pillow lava flows; and pil- 

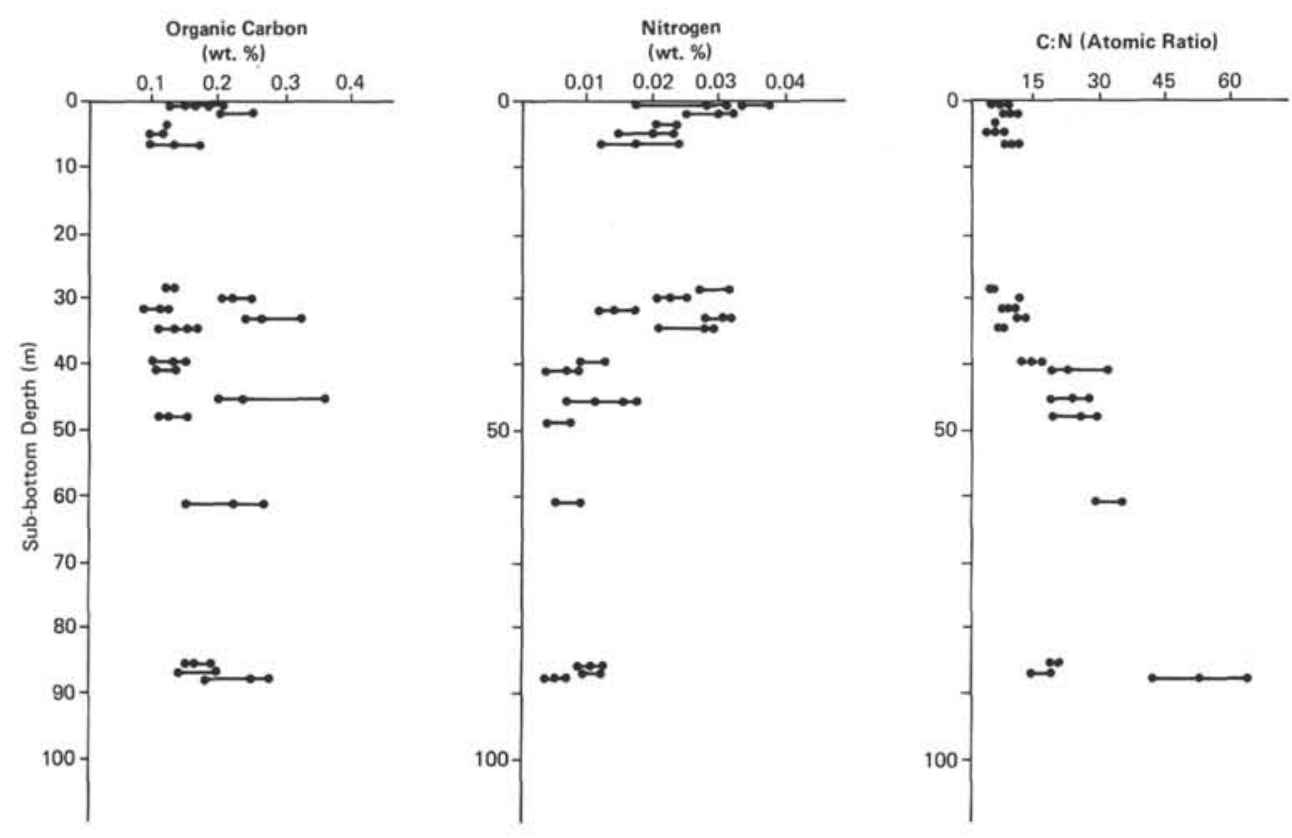

Figure 8. Results of organic carbon and nitrogen analyses of sediment samples versus depth in sub-bottom meters.

Table 3. Qualitative estimate of the relative amounts of free hydrocarbon, bound hydrocarbon, and $\mathrm{CO}_{2}$ from kerogen (and carbonate-rich sediments) based upon sizes of $S_{1}, S_{2}$, and $S_{3}$ peaks, respectively, from Rock Eval analyses.

\begin{tabular}{ccccc}
\hline $\begin{array}{c}\text { Lithologic Unit } \\
\text { or Sub-unit }\end{array}$ & $\begin{array}{c}\text { No. of } \\
\text { Samples }\end{array}$ & $\begin{array}{c}\text { Free } \\
\text { Hydrocarbon } \\
\left(S_{1}\right)\end{array}$ & $\begin{array}{c}\text { Bound } \\
\text { Hydrocarbon } \\
\left(S_{2}\right)\end{array}$ & $\begin{array}{c}\mathrm{CO}_{2} \text { from } \\
\text { Kerogen } \\
\left(S_{3}\right)\end{array}$ \\
\hline 1 & 11 & + & +++ & + \\
2 & 4 & + & - & ++ \\
$3 \mathrm{a}$ & 2 & + & + & + \\
4 & 2 & + & +++ & + \\
$5 \mathrm{a}$ & 1 & + & + & + \\
\hline
\end{tabular}

Note: $-=$ undetectable, $+=$ minor, $++=$ moderate, and $+++=$ major relative amounts.

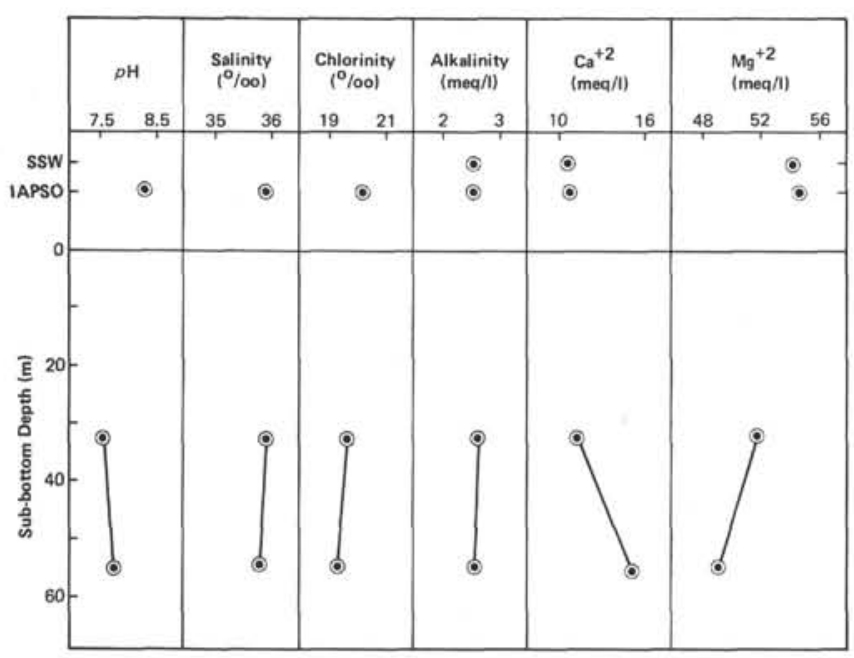

Figure 9. Results of analyses of interstitial water samples versus depth in sub-bottom meters. Values for $p \mathrm{H}$, salinity, chorinity, alkalinity, and $\mathrm{Ca}$ - and $\mathrm{Mg}$-ion concentrations in millimoles per liter are plotted. (IAPSO standard and a surface sea water sample are shown for comparison.) lowed massive flows composed of upper pillow lavas underlain by a massive flow. Two eruptive units of the single lava flow type are distinguished (Sub-unit 6a and Unit 9). Sub-unit $6 \mathrm{a}$ is a massive basalt flow 2 meters thick, and Unit 9 is a massive basalt flow 9.5 meters thick with doleritic affinities in its interior.

There are five units of pillow lava flows from 7 to 35 meters thick. These cooling units may be composed of smaller cooling units, but further subdivision cannot be made with available evidence. The pillows themselves range in diameter from 0.25 meters to 1.5 meters and average 0.5 meters.

Many eruptive units composed of an upper layer of pillow lava (1.0-12.0 m thick, averaging $5.2 \mathrm{~m}$ ) that grades into a lower massive flow base (1.0-7.5 m thick, averaging $3.6 \mathrm{~m}$ ) have been identified as pillowed massive flows. These compound flows are from 2 to 19 meters thick, and the pillowed portion comprises an average of $60 \%$ of each unit. The rhythmic sequence of pillow lava-massive flow is a striking feature of the lithology of Hole 447A. Of the 18 probable cooling units, 11 are of this compound type. We consider each pillowed unit and the underlying massive flow to constitute a single eruptive unit, rather than two separate flows, in much the same manner that autobreccia is part of an underlying massive subaerial flow.

An area of intense brecciation occurs within the lava pile at a sub-basement depth of 114 meters $(227 \mathrm{~m}$ subbottom). The zone of brecciation cuts the core at an angle of approximately $65^{\circ}$ and is about 0.6 meters thick (true). The occurrence of this brecciated zone is interpreted as a minor fault with rather limited movement $(<1 \mathrm{~m})$.

The deepest basalts recovered (Sub-unit 11f) contain xenoliths of anorthositic cumulates and xenocrysts of resorbed gabbroic plagioclase and spinel, both of which are clearly out of equilibrium with the melt. Seismic 
data have shown that Layer 2 is abnormally thin in the region of Hole $447 \mathrm{~A}$. The appearance of cumulate inclusions and xenocrysts suggests that the basalts of Sub-unit $11 \mathrm{f}$ may contain phases carried from cumulate magma chambers from Layer 3.

As discussed in the petrology chapters (this volume), the basalts are chemically and mineralogically indistinguishable from mid-ocean ridge (MOR) tholeiitic basalts. The basalts are subdivided on the basis of phenocryst content as follows:

1) aphyric to olivine-spinel-phyric-Unit 9

2) plagioclase-phyric-Units 6,7

3) plagioclase-olivine-spinel-phyric-Unit 11

4) plagioclase-clinopyroxene-olivine-phyric-Unit 8

5) olivine-plagioclase-clinopyroxene-phyric-Unit 10.

The majority of the pillow lavas have prominent, usually fresh, glassy rims. The glassy rims vary from 1 $\mathrm{mm}$ to $2 \mathrm{~cm}$ in width and grade through hyalopilitic into variolitic basalt toward the pillow interior. The cores of the pillows are fine-grained, intersertal to ophitic in texture, but are rarely more than $75 \%$ crystalline except in the largest pillows. Pillows composed of porphyritic basalt commonly show gravity settling of phenocrysts, notably olivine.

Interpillow glass breccias are common. These glass breccias are composed of shards and fragments, which may be fresh or altered to either palagonite or green, concentrically banded smectites. The breccias are cemented and commonly veined with secondary carbonate and zeolite minerals.

The massive basalt flows, usually between 75 and $100 \%$ crystalline, have textures that range from intersertal, through pilotaxitic, to strongly ophitic. Grain size varies from fine to medium-grained.

Most of the basalts from Hole 447A show extensive low-temperature alteration. Only very rarely is fresh olivine observed and only as relict cores. Olivine alters chiefly to a rusty-brown acicular aggregate of smectite and $\mathrm{Fe}$ oxides, readily visible in hand specimen. Interstitial glass alters to a similar aggregate of brown smectites; however, pillow margin glass is commonly altered to green smectites. Plagioclase is only rarely altered, and, except in cases of extreme alteration, pyroxene remains fresh.

Vesicles within the basalts are rare (in most cases less than a few per cent of the rock) and commonly are partially or completely filled with brown smectites, green smectites, carbonates, and, in some cases, with zeolites.

Pillowed basalts show the greatest contrast in degree of alteration. Usually at least some of the glass remains fresh, whereas the hyalopilitic or variolitic material adjacent to the margin is commonly oxidized to an extremely altered, mottled pale-brown basalt. The cores of the pillows contain the freshest basalts except for remnants of quenched basaltic glass on the margins. Veins and cavities of calcite, zeolites (phillipsite), sulfides, and rare quartz are present, especially as filling of radial cooling fractures within the pillow basalts. Brown zones of oxidized basalts have formed adjacent to these veins. Least-altered crystalline basalts are found in fracture- free parts of the coarsest zones of massive flows. No high-temperature alteration minerals (e.g., chlorite, epidote, or actinolite) have been observed, and all the alteration and veining described are considered to be of low-temperature origin.

In the following petrographic descriptions, the abundance of phenocrysts and groundmass constituents are given as percentages of the whole rock (for example, the rock consists of $10 \%$ phenocrysts, $5 \%$ vesicles, and $85 \%$ groundmass), whereas the abundance of individual phenocrysts or groundmass constituents are given as percentages of the total phenocrysts or total groundmass constituents (for example, the phenocrysts consist of plagioclase $[60 \%, 0.8 \mathrm{~mm}]$ and olivine $[40 \%, 0.4$ $\mathrm{mm}$, altered to green smectite]; the groundmass consists of plagioclase [50\%], both pyroxenes [20\%], opaques [5\%], and glass [25\%]).

Unit 6 (113.0-131.5 m sub-bottom) is composed of 18.5 meters of plagioclase-phyric tholeiitic basalts and can be divided into four sub-units.

Sub-unit $6 \mathrm{a}$ is a massive plagioclase-phyric basalt flow about 2 meters thick, gray, fine-grained, with sparse spherical vesicles $(5 \%, 0.5-5 \mathrm{~mm})$ filled with carbonates, sometimes rimmed with yellowish green smectite. Two per cent plagioclase phenocrysts $(2 \mathrm{~mm}$, $\sim \mathrm{An}_{75}$ ) and less than $2 \%$ plagioclase glomerocrysts are present in the rock. The subophitic to almost holocrystalline ophitic groundmass is composed of plagioclase laths $\left(50 \%, \sim 0.5 \mathrm{~mm}\right.$ long, $\left.\sim \mathrm{An}_{68}\right)$, granular plumose clinopyroxene $(45 \%, 0.2 \mathrm{~mm})$ between plagioclase laths, and magnetite $(5 \%, 0.01 \mathrm{~mm}$ granular crystals). Small grains of olivine $(0.1 \mathrm{~mm})$ may have been replaced completely by smectite and carbonate minerals. The flow is crisscrossed by several generations of veins (1-2 mm thick) filled mainly with carbonate minerals.

Sub-unit $6 \mathrm{~b}$ consists of 8 meters of plagioclase-phyric pillow basalt similar in petrography to Sub-unit $6 \mathrm{a}$. The rock varies in texture from almost glassy on the margins of pillows to holocrystalline ophitic in the interior. Pillows are crossed by rare, small $(1-2 \mathrm{~mm})$, finegrained dikes of the same mineralogic composition as the host pillow; these may be segregation veins filter pressed out of crushed pillows. The pillows are also cut by veins $(0.5-1 \mathrm{~mm})$ filled mainly by carbonates. Scattered vesicles, which are mostly spherical, range in size from 0.05 to $0.1 \mathrm{~mm}$ and make up only $3 \%$ of the rock; these are partially or completely infilled with carbonates rimmed by smectite. Sparse glomerocrysts of plagioclase $(1 \mathrm{~mm})$ occur. The inner parts of pillows show a subophitic groundmass. The groundmass consists of plagioclase laths $(45 \%, \sim 0.8 \mathrm{~mm}$ in length), clinopyroxene $(45 \%)$, olivine $(3 \%$, completely replaced with clays and carbonates), magnetite euhedra (2\%), and alteration products $(5 \%)$. The latter mainly consist of carbonates, clays (after olivine and some clinopyroxene), and hematite (after magnetite).

Sub-units $6 \mathrm{c}$ and $6 \mathrm{~d}$ are petrographically similar and consist of pillowed massive flows of plagioclase-phyric basalts ( $2 \mathrm{~m}$ and $6.5 \mathrm{~m}$ thick, respectively). Massive basaltic flows and the interior of pillows are approx- 
imately 80 to $85 \%$ crystalline, gray in color, finegrained, with frequent pale-brown mottling and brown patches along cracks (due mainly to alteration of groundmass). Only about $3 \%$ blocky plagioclase glomerocrysts are present in both sub-units. Thin veins $(0.5$ mm-1 mm) are filled with carbonates and zeolites. Vesicles $(3 \%, 0.1 \mathrm{~mm})$ appear to be largely empty or partially infilled with carbonates, zeolites, and smectites. Scattered irregular vugs are lined with zeolites. The groundmass is characterized by a subophitic texture and consists of plagioclase laths $(50 \%, 0.8 \mathrm{~m})$, granular clinopyroxene $(44 \%, 0.2$ to $0.4 \mathrm{~mm})$, olivine ( $3 \%$, completely replaced with clays), magnetite $(3 \%, 0.02 \mathrm{~mm})$, and alteration products (carbonate, clays, and smectite-which replaces olivine-intergranular glass, and some pyroxene and plagioclase).

Unit 7 (131.5-141.0 m sub-bottom) consists of 9.5 meters of plagioclase-phyric tholeiitic pillow basalt. As in the basalts of the previous unit, the inner parts of the pillows are about $80 \%$ crystalline, fine-grained, and characterized by subophitic texture and low vesicularity $(3 \%)$. Only sparse plagioclase phenocrysts exist. Vesicles are filled with smectite and carbonate. Rarely, the basalt becomes somewhat coarse and approaches dolerite; otherwise, it is very uniform. The groundmass consists of plagioclase laths $\left(50 \%, 1 \mathrm{~mm}, \sim \mathrm{An}_{68}\right)$, euhedral clinopyroxene $(35 \%)$, pseudomorphs of olivine $(10 \%$, $0.25 \mathrm{~mm})$, and magnetite and alteration products $(5 \%)$. Olivine and glass are replaced completely with aggregates of clay, carbonate, and smectite. Pyroxene and plagioclase have undergone relatively slight alteration.

Unit 8 (141.0-185.0 m sub-bottom) is divided into four pillowed massive flow cooling units. The basalts belonging to this unit are plagioclase-clinopyroxeneolivine-phyric tholeiites.

Sub-unit $8 \mathrm{a}, 13.5$ meters thick, is composed of a 1.4-meter-thick massive flow overlain by 12.1 meters of pillow basalt. The basalts contain up to $20 \%$ phenocrysts consisting of euhedral to subhedral olivine ( $\sim 50 \%, 0.9-1.0 \mathrm{~mm}$, pseudomorphed by brown smectite and sometimes carbonate and zeolite), and glomerocrysts of plagioclase $\left(\sim 50 \%, 1-2 \mathrm{~mm}, \mathrm{An}_{70-85}\right)$. The groundmass is hyalopilitic and variolitic to subophitic with up to $80 \%$ glass, depending on the position within the pillowed massive flow. Plagioclase, clinopyroxene, and glass are the dominant groundmass minerals with subordinant magnetite. Vesicles are usually less than $1 \%$ of the groundmass and lined with either calcite and zeolites or dark olive smectite.

Sub-unit $8 \mathrm{~b}$ is 12.5 meters thick and consists of a 2.5-meter thick massive flow overlain by 10.0 meters of pillow basalt. The groundmass is hyalopilitic to subophitic and contains only slightly more than $5 \%$ phenocrysts consisting of glomerocrysts of plagioclase $(\sim 80 \%, 1.5 \mathrm{~mm})$ and olivine $(\sim 20 \%, 0.6 \mathrm{~mm}$, altered to carbonate and smectite).

Sub-unit $8 \mathrm{c}$ is 3.5 meters thick and consists of a 1.5-meter massive flow overlain by 2.0 meters of pillow basalts, which are similar to those described above, except that they contain less than $10 \%$ phenocrysts, consisting of plagioclase $(<50 \%,<1 \mathrm{~mm})$ and olivine $(50 \%, 1-2 \mathrm{~mm}$, replaced by iddingsite), and have a groundmass very rich in glass. Figure 10A shows variolitic nucleation around microphenocrysts in the glass of a pillow margin.

Sub-unit $8 \mathrm{~d}$ is 14.5 meters thick and consists of an 8.0-meter-thick massive doleritic flow that grades upward into 6.5 meters of pillow basalts. The latter contains about $2 \%$ phenocrysts of olivine and plagioclase $\left(\mathrm{An}_{74}\right)$, similar to those in Sub-units $8 \mathrm{a}$ to $8 \mathrm{c}$. Groundmass textures range from hyalopilitic through variolitic to pilotaxitic (Fig. 10B). The dolerite contains less than $5 \%$ phenocrysts consisting of plagioclase $\left(60 \%, \mathrm{An}_{64-73}\right.$, 1 -cm-long glomerocrysts) and olivine $(<40 \%,<0.5 \mathrm{~mm}$, pseudomorphed by carbonate, smectite, or zeolite). The groundmass is subophitic (grain size about $1 \mathrm{~mm}$ ); dominant minerals are plagioclase $\left(\mathrm{An}_{65}\right)$, clinopyroxene, and titanomagnetite. There is slight alteration of pyroxene to smectite.

Unit 9 (185.0 to 194.0 meters sub-bottom) is 9.0 meters thick and consists of aphyric to sparsely olivinespinel-phyric, fine- to medium-grained, gray, almost holocrystalline dolerite. The texture is ophitic to subophitic (near the base) as shown in Figure 10C. The vesicularity is low and ranges from $0-2 \%$ with vesicles $(0.05 \mathrm{~mm})$ partially filled with green smectite. Veins are absent except near the base of the unit. Thin sections indicate a groundmass composition of plagioclase $(50 \%$, $\left.A n_{72}\right)$, clinopyroxene $(45 \%)$, and magnetite $(5 \%)$. The dolerites are fresh and have undergone only slight secondary alteration. Near the base of Unit 9, olivine phenocrysts appear and gradually increase in quantity downward toward the boundary with Unit 10 .

Unit 10 (194.0-209.0 m sub-bottom) is 15.0 meters thick and consists of olivine-plagioclase-clinopyroxenephyric tholeiitic basalts. It can be divided into two subunits.

Sub-unit $10 \mathrm{a}$ is 9.5 meters thick and is a pillowed massive basalt flow. These pillows have fine-grained, extremely altered tops and bottoms rimmed with completely altered glass. The glass is mainly replaced with yellowish green smectite. Inner parts of the pillows are coarser and consist of crystallized basalt with phenocrysts and microphenocrysts of olivine, plagioclase, and clinopyroxene. Scattered vesicles $(2 \%, 0.05 \mathrm{~mm})$ are filled with brown smectite. Pillows are veined by finegrained aggregates of carbonates and zeolites. A thin section from a pillow core indicates sparse phenocrysts and microphenocrysts of olivine, plagioclase, clinopyroxene $(50 \%)$, magnetite, and products of groundmass alteration $(5 \%)$.

Sub-unit $10 \mathrm{~b}$ is 5.5 meters thick and consists of a pillowed massive olivine-plagioclase-clinopyroxenephyric basalt, with an ophitic to subophitic groundmass. The latter is composed of plagioclase $(50 \%)$, clinopyroxene $(50 \%)$, and opaques and alteration products $(5 \%)$.

Unit 11 (209.0-296.5 m sub-bottom) is 87.5 meters thick and consists of plagioclase-olivine-phyric tholeiitic basalts. It is subdivided into five pillowed massive flow units and one basalt pillow lava unit.

Sub-unit $11 \mathrm{a}$ is 19.5 meters thick and comprises a 9.0-meter basal flow overlain by 10.5 meters of pillowed massive basalts, which contain $5 \%$ phenocrysts con- 

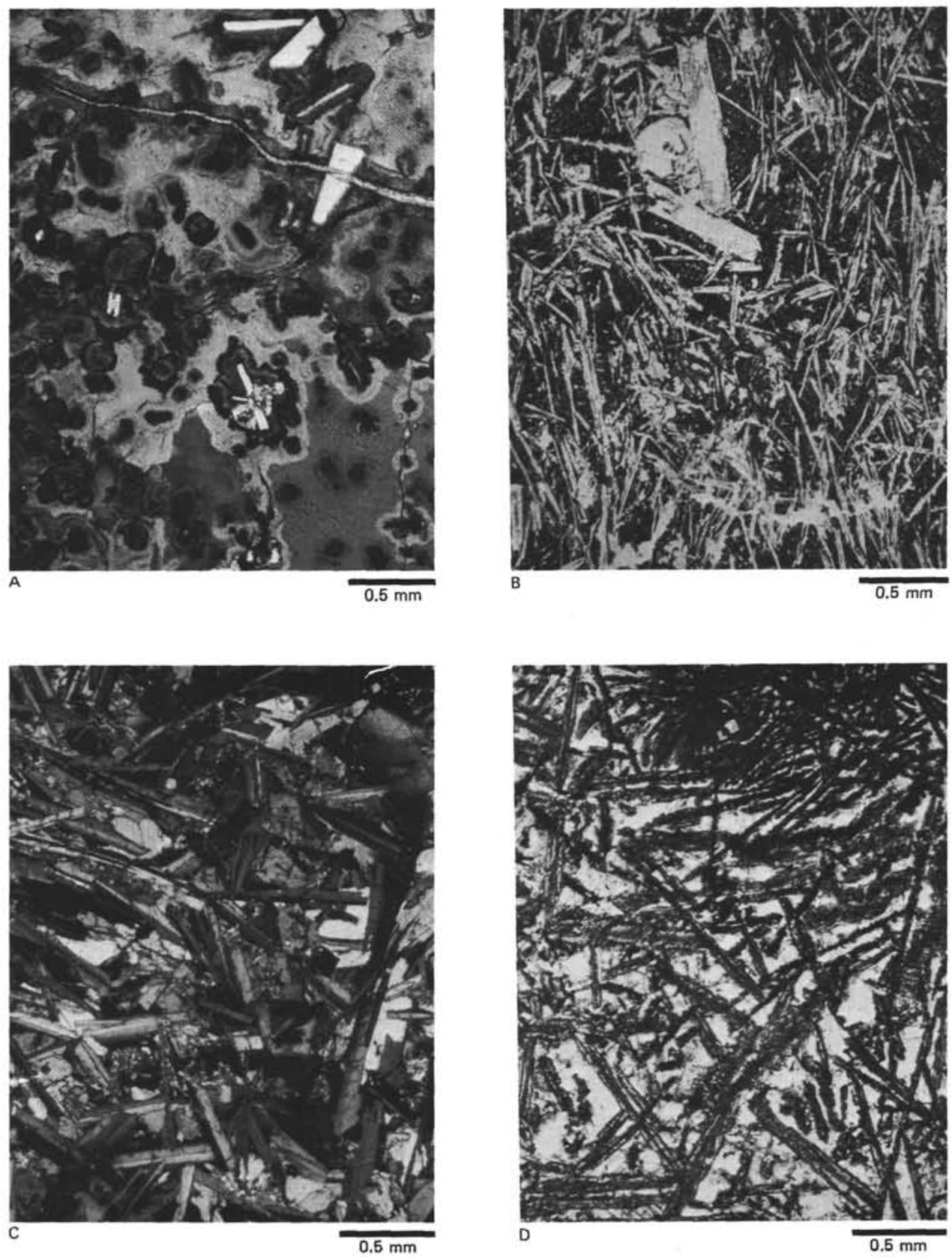

Figure 10. A. Variolitic growths nucleating around microphenocrysts during the initial stages of devitrification of fresh glass from a pillow margin of Sub-unit 8c. (A thin radial fracture is filled with calciteSection 447A-21-1, [Piece 11]; plane polarized light; bar is $0.5 \mathrm{~mm}$ long.) B. Plagioclase phenocrysts in a flow-banded hyalopilitic groundmass composed of plagioclase microlites and altered glass. (Center of pillow from near the top of Sub-unit 8d-Section 447A-21-4, [Piece 3]; plane polarized light; bar is $0.5 \mathrm{~mm}$ long.) C. Ophitic dolerite from massive flow base of Unit 9. (Section 447A-24-2 [Piece 2e]; cross polarized light; bar is $0.5 \mathrm{~mm}$ long.) D. "Anti-ophitic" texture from a clast of hyalopilitic basalt contained in a zone of brecciation in Unit 11a. (This texture is characterized by the occurrence of lathlike or plumose clinopyroxene crystals that are commonly slightly curved. These crystals are subpoikilophitically enclosed by plagioclase, creating the antithesis of ophitic texture-Section 447A-29-1, [Piece 2a]; plane polarized light; bar is $0.5 \mathrm{~mm}$ long.)

sisting of euhedral olivine $(50 \%$, microphenocrysts to $1.5 \mathrm{~mm}$, pseudomorphed by green and gray smectite), subhedral plagioclase $(50 \%, 0.5$ to $2 \mathrm{~mm}$, partly or wholly altered to zeolites and pale-green smectite), and rare clinopyroxene $(0.5 \mathrm{~mm}$, altered). A few translucent brown chrome spinel microphenocrysts occur. The groundmass displays a complete range of textures, depending on the degree of quenching (glassy, hyalopilitic, variolitic, intersertal, subophitic, and pilotaxitic). Groundmass minerals include plagioclase $\left(\sim \mathrm{An}_{67}\right)$, 
clinopyroxene, and titanomagnetite. Vesicles make up less than $5 \%$ of the total rock and are infilled with carbonate and smectite.

Within this cooling unit is a 0.6-meter-wide breccia, which may represent a fault zone as previously discussed. The breccia clasts display a very wide range in texture, including the inverse of an ophitic texture, or an "anti-ophitic" texture, characterized by thin laths of clinopyroxene set in a plagioclase matrix (Fig. 10D). This texture occurs at the edge of a normal glassy zone adjacent to a vein of calcite. It is doubtful that it is related to the calcite vein, because no evidence of hightemperature alteration exists.

Sub-unit $11 \mathrm{~b}$ is 6.5 meters thick and consists of a 5.0-meter massive flow overlain by 1.5 meters of pillow basalt similar to those described from Sub-unit 11a. These basalts of Sub-unit $11 \mathrm{~b}$ contain phenocrysts of olivine, plagioclase, rare clinopyroxene, and chrome spinel set in a variolitic groundmass.

Sub-unit $11 \mathrm{c}$ is 4.5 meters thick and consists of a 1.5-meter massive flow overlain by 3.0 meters of pillow basalt. In hand specimen, it is similar to Sub-units 11a and $11 \mathrm{~b}$, containing $10 \%$ phenocrysts of altered olivine and plagioclase set in an ophitic or fine-grained ophitic groundmass.

Sub-unit $11 \mathrm{~d}$ is 7.5 meters thick and is composed entirely of pillow basalts containing $7 \%$ phenocrysts of anhedral olivine $(30 \%, 1 \mathrm{~mm}$, completely altered) and subhedral plagioclase $(70 \%, 0.5-0.7 \mathrm{~mm}$, partially altered) set in an intersertal to pilotaxitic groundmass composed of plagioclase $\left(\mathrm{An}_{70}\right)$ and plumose clinopyroxene. Rare octohedra of chrome spinel occur in the glass. Spherical vesicles lined with zeolite and smectite form $3 \%$ of the rock.

Sub-unit $11 \mathrm{e}$ is 35.0 meters thick, is generally rather uniform, and consists of plagioclase-olivine-phyric pillow basalts. The inner parts of the pillows have phenocrysts of olivine and plagioclase with sparse glomerocrysts in a fine-grained matrix. Olivine is observed only as pseudomorphs replaced with smectite, calcite, clay, and zeolites. The groundmass is subophitic and is composed of plagioclase laths $\left(45 \%, 0.5 \mathrm{~mm}, \sim \mathrm{An}_{69}\right)$, plumose clinopyroxene $(35 \%, 0.02 \mathrm{~mm})$ crystallized between the plagioclase laths, completely altered olivine $(10 \%, 0.1-0.2 \mathrm{~mm})$, opaques $(5 \%)$, and glass and alteration products $(5 \%)$. Pillows enriched with either plagioclase or olivine phenocrysts are commonly observed. It is noteworthy that basalts of the lower part of the unit contain small $(0.2 \mathrm{~mm})$ resorbed, euhedral xenocrysts of spinel; these spinels are included in olivine and in the glassy matrix (the spinels are almost completely absent in the middle and upper parts of the unit). Peripheral zones of pillows are characterized by hyalopilitic to variolitic textures. The groundmass contains phenocrysts of plagioclase and olivine and microphenocrysts of clinopyroxene and plagioclase. Most of the marginal glassy rims of pillows are completely altered and replaced with green smectite. Examples of local interpillow autobrecciation of glassy rims are common. Fragments of glass and fine-grained basalts on pillow peripheries are cemented with a fine-grained mass of zeolites and carbonates. Pillows contain rare, scattered, spherical vesicles $(1-2 \%, 0.2-0.3 \mathrm{~mm})$, most of which are completely filled zeolites, carbonates, and smectites.

Sub-unit $11 \mathrm{f}$ is at least 14.5 meters thick and is the deepest penetration in Hole 447A (total depth $=296.5$ $\mathrm{m}$ sub-bottom). It is a plagioclase-olivine-tholeiitic basalt that appears identical to Sub-unit 11e except for the occurrence of an anorthositic cumulate xenolith and plagioclase and spinel xenocrysts. The basalts contain about $10 \%$ phenocrysts of anhedral olivine $(10 \%, 1-$ $2 \mathrm{~mm}$, pseudomorphed by brown smectite and zeolite), euhedral plagioclase $(<90 \%, 1.2 \mathrm{~mm})$, and translucent, brown octahedra of chrome spinel $(0.2 \mathrm{~mm})$. The chrome spinel occurs as microphenocryst inclusions both in glass and olivine pseudomorphs. The groundmass is 80 to $100 \%$ crystalline, subophitic, often with plumose clinopyroxene.

The xenocrysts of anhedral gabbroic plagioclase $(0.5-2 \mathrm{~cm}$ in diameter) are extremely well rounded, probably because of magmatic corrosion. They also have large anhedral inclusions of brown chrome spinel (0.5-3 mm diameter), suggesting the gabbroic origin. Isolated xenocrysts of spinel show strong disequilibrium with the host basalt (strongly corroded outline with deep embayments). The small xenolith of a fine-grained $(\sim 5 \mathrm{~mm})$ anorthositic cumulate occurs near the base of the unit. The cumulate texture of the plagioclase probably suggests that this xenolith was part of the cumulate portion of a gabbroic magma chamber.

\section{METAMORPHIC PETROGRAPHY}

Although extensive alteration of basaltic flows and pillow lavas occurs at glassy boundaries and within brecciated portions of the units, only low-temperature alteration phases exist; unambiguous petrographic evidence of either hydrothermal metamorphism of the rocks or high-temperature hydrothermal vein formation is not found. The presence of phillipsite in veins with calcite cannot be taken as an indicator of zeolite-grade metamorphism, because authigenic phillipsite forms at sediment-column ambient temperatures during sediment diagenesis.

\section{CONTACT RELATIONS AND STRATIGRAPHY}

\section{The Igneous/Sedimentary Contact}

Igneous/sedimentary contacts and stratigraphic relations in Hole 447A are difficult to interpret. Within the lower 47 meters of the middle Oligocene sedimentary sequence (Sub-unit 3b-Unit 5), basaltic clasts occur with increasing abundance, size, and freshness down-section. In the lower 26 meters of this sequence (Unit 5), volcanic glass is abundant in the matrix of sedimentary rocks. In the lowest meter above the igneous contact, 5 -cm-diameter clasts similar to the uppermost basalt flow are found. Because these clasts are brecciated, highly angular pieces of basalt, they were probably derived as talus associated with local fault scarps. Two interpretations are possible. The first is that the basalt basement is only slightly older than the overlying middle Oligocene sediments. This hypothesis suggests that shortly after extrusion of basalts along the spreading-center axis, local tectonic activity, associated 
with the accreting plate margin or transform faulting, shed fault-scarp debris on the basalt flow. This interpretation necessitates that the basaltic basement is of the middle Oligocene (about $32 \mathrm{~m} . \mathrm{y}$.); such a hypothesis is in conflict with the plate-tectonic reconstruction of Hilde et al. (1976) and with the magnetic-age estimates of Louden (1976), both of which posit that the age of the basement at Hole $447 \mathrm{~A}$ is roughly $50 \mathrm{~m} . \mathrm{y}$. Still another objection to basaltic basement being only slightly older than the overlying middle Oligocene sediments is the absence of a source of numerous sedimentary clasts in the overlying polymicitic breccia of Unit $3 \mathrm{~b}$. Note the discussion on Accumulation Rates in this report in which the breccias are thought to accumulate over a very short peroid of time.

The second interpretation of the contact resolves inconsistencies in the first but creates new problems: If basaltic basement is approximately $50 \mathrm{~m}$.y. old, then a mechanism is required first to strip off sediments that accumulated between 50 and $30 \mathrm{~m} . \mathrm{y}$. ago and then to deposit a tectonic igneous breccia on that resulting erosion surface. These tectonic events must occur in old ocean crust. Resolution of this problem may be found by superimposing back-arc tectonics on the West Philippine Basin when the Palau-Kyushu Ridge became a subduction zone in the late Eocene (Hilde et al., 1976). Although the effects of arc formation on the edge of a trapped marginal basin are unknown, it is probable that enough vertical tectonism was felt close to the PalauKyushu Ridge to strip off older sediments and subsequently to deposit middle-Oligocene breccias on the older basement by local fault movements. Distinction between these two interpretations has not been established by radiometric dating of the basement rocks, because alteration effects could not be removed (see Sutter and Snee, this volume). Perhaps more definitive magnetic-anomaly identification may resolve the age of the West Philippine Basin.

\section{The Distinction between Extrusive Units}

Identification of extrusive cooling units within a volcanic sequence is difficult when the units include pillow lavas, even if the glassy margins of the cooling units are preserved. The glassy margins between two pillows within a pillow-lava cooling unit have the same physical characteristics as do the glassy margins between two massive flow cooling units and the glassy margins between two pillow lava cooling units. Apparently, alteration by sea-water migration along glassy boundaries affects pillow contacts within a cooling unit in the same manner as it affects exterior contacts of the entire cooling unit. A logical boundary to use as stratigraphic marker between extrusive cooling units is the glassy base of a massive flow unit. If this stratigraphic marker is used, three types of extrusive cooling units are recognized: (1) a single massive flow unit (for example, Unit 9); (2) a pillow lava flow sequence with no apparent lithologic breaks (for example, Sub-unit 11e); and (3) a sequence of pillows that are so lithologically similar to an underlying flow that they appear to have formed as one extrusive cooling unit (for example, Sub-units 8a-8d). These are called pillowed massive flows.

No major problems are associated with recognition of single massive-flow units as long as the glassy contact is preserved. A problem does exist with the second category of extrusive cooling unit. A pillow lava flow sequence of similar lithologies cannot be subdivided into individual igneous extrusive events, and thus only a minimum number of cooling units are recognized. Problems also exist in recognition of the third type of extrusive cooling unit, the pillowed massive flow. The pillowed massive flow in a subaqueous environment is somewhat analogous to the autobrecciated flow in the subaerial environment. If this analogy holds, then a problem exists in the subaqueous case because some of the autobrecciated rind of subaerial flows is overrun by the flow itself in a "tractor-tread" fashion, which creates a thin layer of autobreccia at the flow base in addition to the thick autobreccia at the flow top. Thus, a subaqueous flow may also incorporate some of its pillow lava top under the advancing flow front. Obviously, a distinction between pillows of this "tractortread" origin and pillows from an underlying, petrographically similar cooling unit cannot be made in the drill core. For this reason, the base of a pillowed massive flow cooling unit is arbitrarily defined at the glassy base of the flow. Notwithstanding, this definition of a flow boundary still allows intelligent petrologic sampling of major extrusive cooling units and therefore justifies use of this arbitrary demarcation between units.

Fortunately, recovery of basalt core in Hole 447A was unusually high, preserving many of the critical glass contacts; of 183.5 meters cored, over 100 meters (nearly $60 \%$ ) were recovered. Therefore, thick massive flow units (for example, Unit 9) can be distinguished by glassy bases as extrusive cooling units rather than as sills or dikes, even though the centers of these flows have a doleritic character (crystals greater than $1 \mathrm{~mm}$ in diameter with ophitic textures). In contrast, an intrusive cooling unit would not have glassy tops and bottoms.

\section{PILLOW LAVAS}

The pillows within the lavas of Hole 447A show the following zones from their outer crust to their interiors: a black to dark-green glass zone commonly $5 \mathrm{~cm}$ thick; a brownish gray to gray variolitic zone, 5 to $10 \mathrm{~cm}$ thick; a pale-brown to dark-brown transition zone up to $20 \mathrm{~cm}$ thick; and a dark-gray to dark-green crystalline interior. Glass zones are indicators of pillow boundaries and may be present on the tops of the pillows (upper glass zones), on the bottoms (lower glass zones), or on both, depending upon core recovery and mode of pillow formation (Table 4). We recognize more pillows with upper glass zones than those with lower glass zones. With rare exception, pillow lavas break into drill-core pieces at glass junctions; thus, it is not clear whether the absence of lower glass zones is a function of (1) drilling physics or (2) pillow lava formation. During drilling, the tops and bottoms of core pieces usually form, respectively, ball and socket joints; the tops are convex up and the bot- 
Table 4. Number of pillows found in core recovered in Hole 447A.

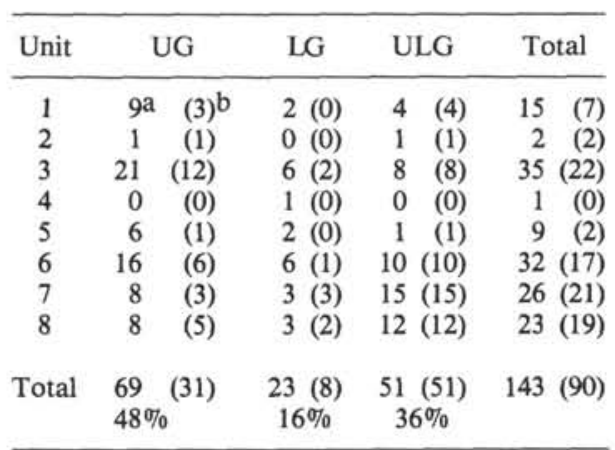

Note: $\mathrm{UG}=$ upper glass zone; $\mathrm{LG}=$ lower glass a $\mathrm{cm}$

zone; and ULG = upper and lower glass zone.

$\mathrm{b}$ The number in parentheses is the number of pillows used for size estimation.

toms are concave down. The concave-down pieces of core have probably lost bottom chips, resulting in fewer glass bottoms relative to glass tops. If drilling physics is not responsible for the bias toward more glassy tops than bottoms, then perhaps the phenomenon is caused by a difference between formation of pillow tops and bottoms. The observed ratio of upper glass to lower glass zones is 3:1. In well-preserved cores, three types of boundary relationships between neighboring pillows can be observed: upper pillow glass in contact with lower pillow glass; upper pillow glass in contact with lower pillow variolitic zone or marginal transition zone; and upper pillow variolitic zone or transition zone in contact with lower pillow glass. The reason for the absence of the lower glass zone on some pillows is uncertain, but perhaps either the lower pillow was still hot when the upper pillow formed or exposure to sea-water cooling was insufficient to chill the pillow bottoms adequately and preserve glass.

We measured the distance between both the horizontal and inclined upper and lower pillow margins in wellpreserved cores recovered from Hole 447A. Many glass margins, however, were found to be inclined to the drillcore axis. If it is assumed that recovered fragments are correctly oriented, these inclined margins can be used in the size estimates. Assuming the pillows possessed parallel upper and lower surfaces and assuming the drill core penetrated the pillow off center and thus the true thickness $D$ in Figure 11 was not recovered, the measured distance $L$ represents an apparent thickness less than the true thickness of the pillow. The total of 90 measured pillows (Table 5) gives a mean minimum thickness of $44 \mathrm{~cm}$; the modal thickness is $30 \mathrm{~cm}$, with a total range in thickness of from 10 to $140 \mathrm{~cm}$ (Fig. 12). Assuming the pillow to be the two half spheres of diameter $D$ and to have flat upper and lower surfaces as drawn in Figure 11, the attitude of the glassy layers can be used to solve the equation $D=L / \cos \theta$, in which $L$ is the distance between the chilled margins and $\theta$ the angle of dip relative to the drill-core axis.

We measured several pillows in well-recovered cores $(<80 \%)$ for the parameters $L$ and $\theta$, and the results

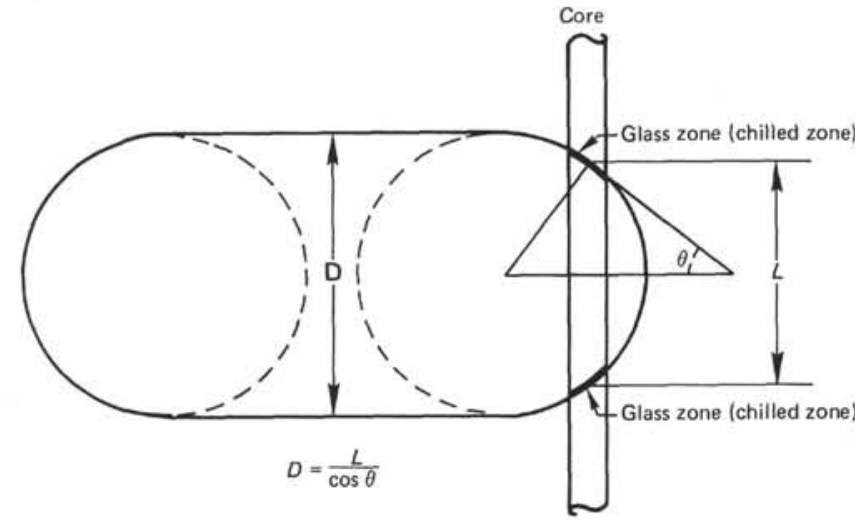

Figure 11. The assumed relative dimensions of pillows. (Estimates of the diameters $[D]$ of pillows are based upon the measured distance $[L]$ between the chilled zones in the drill core and the angle $[\theta]$ formed by the tangent to the chilled zone and the horizontal. The angle $\theta$ is the measured dip of the glassy margins.)

Table 5. Mean minimum diameter of pillows.

\begin{tabular}{|c|c|c|c|c|c|c|c|}
\hline \multirow{2}{*}{$\frac{\text { Unit }}{1}$} & \multicolumn{2}{|c|}{ UG } & \multicolumn{2}{|c|}{ LG } & \multicolumn{2}{|c|}{ ULG } & Mean \\
\hline & $38^{\mathrm{a}}$ & $(3)^{b}$ & & & 42.5 & (4) & $40.5 \quad$ (7) \\
\hline 2 & 45 & (1) & & & & (1) & $42.5 \quad$ (2) \\
\hline 3 & 36 & (12) & 25 & (2) & 58 & (8) & 40.5 (22) \\
\hline 4 & & - & & & - & & - \\
\hline 5 & 45 & (1) & & & 25 & (1) & $35.0 \quad$ (2) \\
\hline 6 & 41 & (6) & 60 & (1) & 66.5 & (10) & 56.5 (17) \\
\hline 7 & 68 & (3) & 60 & (3) & 45.4 & (15) & $51.0(21)$ \\
\hline 8 & 29 & (5) & 65 & (2) & 30 & (12) & 30.0 (19) \\
\hline Mean & 39.7 & (31) & 44.4 & (8) & 47.1 & (51) & $44.0(90)$ \\
\hline
\end{tabular}

Note: $\mathrm{UG}=$ upper glass zone; $\mathrm{LG}=$ lower glass zone; a $\mathrm{cm}$ and $\mathrm{ULG}=$ upper and lower glass zone.

$\mathrm{b}$ The

The number in parentheses indicates the number of pillows used for size estimation.

(Table 6) show that the mean diameter was increased by an average of $25 \%$ over the minimum thickness reported in Table 5. These data suggest that the average diameter of the pillows in Hole 447A is $55 \mathrm{~cm}$.

A similar study was made at Hole 417A, where mean minimum thicknesses were estimated using the assumptions already outlined. The diameters of pillows in Hole $417 \mathrm{~A}$, however, were calculated from measurements of the radial fractures preserved in the pillow margins, a feature more characteristic of the pillows from Hole 417A than from Hole 447A. The pillows at 417A have a mean minimum thickness of $66 \mathrm{~cm}$ and a mean diameter of $92 \mathrm{~cm}$, which is significantly greater than the results obtained from Hole 447A (Donnelly, Francheteau, et al., in press).

\section{PALEOMAGNETISM}

A seafloor magnetic-anomaly study of the Southern Philippine Sea by Louden (1976) suggests that the ocean crust in the vicinity of Site 447 was formed on the northern flank of an east-west oriented north-south spreading center during Cenozoic times. Figure 13 is a summary of regional magnetic studies in the Philippine Sea (Watts et al., 1977; Louden, 1976; Tomoda et al., 1975; 


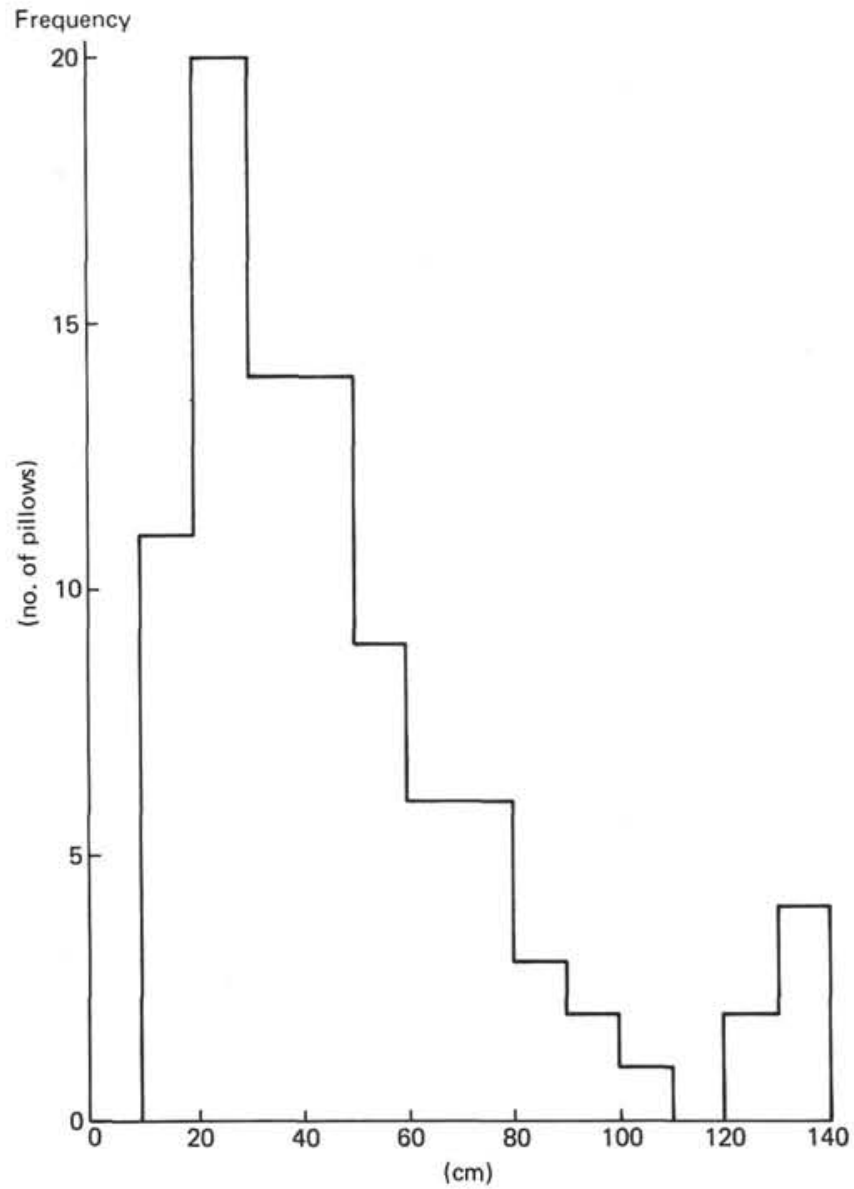

Figure 12. Frequency distribution of the measured minimum diameter of pillows.
Mrozowski and Hayes, 1979). Based upon these studies, we should expect low or equatorial paleolatitudes (inclinations) from samples at the site. This indeed is what we observed.

Only five paleomagnetic samples were collected from the sediment column at the site, owing to poor consolidation and/or drilling disturbance of the sediments. The samples consisted of $2.5 \times 2.5-\mathrm{cm}$ cylindrical cores on which the natural remanent magnetization (NRM) was measured on board ship using a Digico magnetometer and later remeasured on a cryogenic magnetometer. Samples were collected from brown clays (447A-5-2, 76), a lithology characterized by unstable paleomagnetic results (Foster, 1972), and from altered variegated fine tuffs $(447 \mathrm{~A}-10-1,105)$. However, the sample from Core 5 appeared to display stable magnetization and give reliable inclination data; the sample from Core 10 gave anomalously high inclinations $\left(45-47^{\circ}\right)$. A coarsegrained conglomerate with clasts up to $1 \mathrm{~cm}$ (Sample $447 \mathrm{~A}-6-7,39)$, chosen to conduct a sedimentary-conglomerate test for stable magnetization, proved unusual. A conglomerate consists of randomly oriented clasts; thus total magnetization of the sample should reflect the random orientation of its constituent parts, resulting in an anomalous magnetic direction (reflected by the inclination). In this particular case, the results displayed the expected field inclination, suggesting that the conglomerate had been remagnetized subsequent to deposition.

The NRM of 50 basalt samples was also measured on board the Glomar Challenger. The samples consisted of $2.5 \times 2.5 \mathrm{~cm}$ oriented minicores. Alternating field demagnetization studies were also conducted and details of these studies are discussed elsewhere (see Keating and Herrero, this volume). In general, the experiments showed that these samples are directionally stable after cleaning to $1000 \mathrm{Oe}$. Intensities, however, drop to roughly $20 \%$ after demagnetization to 1000 Oe.

The results of NRM measurements are given in Table 7. In general, the paleoinclinations are shallow and appear to be consistent with the seafloor magnetic studies of Louden (1976). Sub-units 11a through 11d appear to be an exception, showing steeper inclinations (mean inclination $=51.5^{\circ}$ ). The mean inclination for all other basalt cooling units is $13.8^{\circ}$. The paleolatitude calculated for this site (all samples) based upon the mean is $10.5^{\circ}$.

No attempt has been made to determine polarity histories for these rocks. The pillow basalts cooled in low paleolatitudes, and if a normal secular variation is considered, it would be sufficient to scatter inclinations, giving the appearance of multiple field reversals. Because the apparent reversals cannot be separated from the true field reversals, it becomes impossible to determine an accurate polarity sequence.

\section{PHYSICAL PROPERTIES}

Measurements of physical properties of pelagic clay, ooze, chalks, volcaniclastic rocks, and basalts cored at Site 447 include sonic velocity (horizontal and vertical), wet-bulk density, water content, porosity, and acoustic
Note: See Figure 11 for explanation of dimensions $\theta, D$, and $L$ of pillows. 


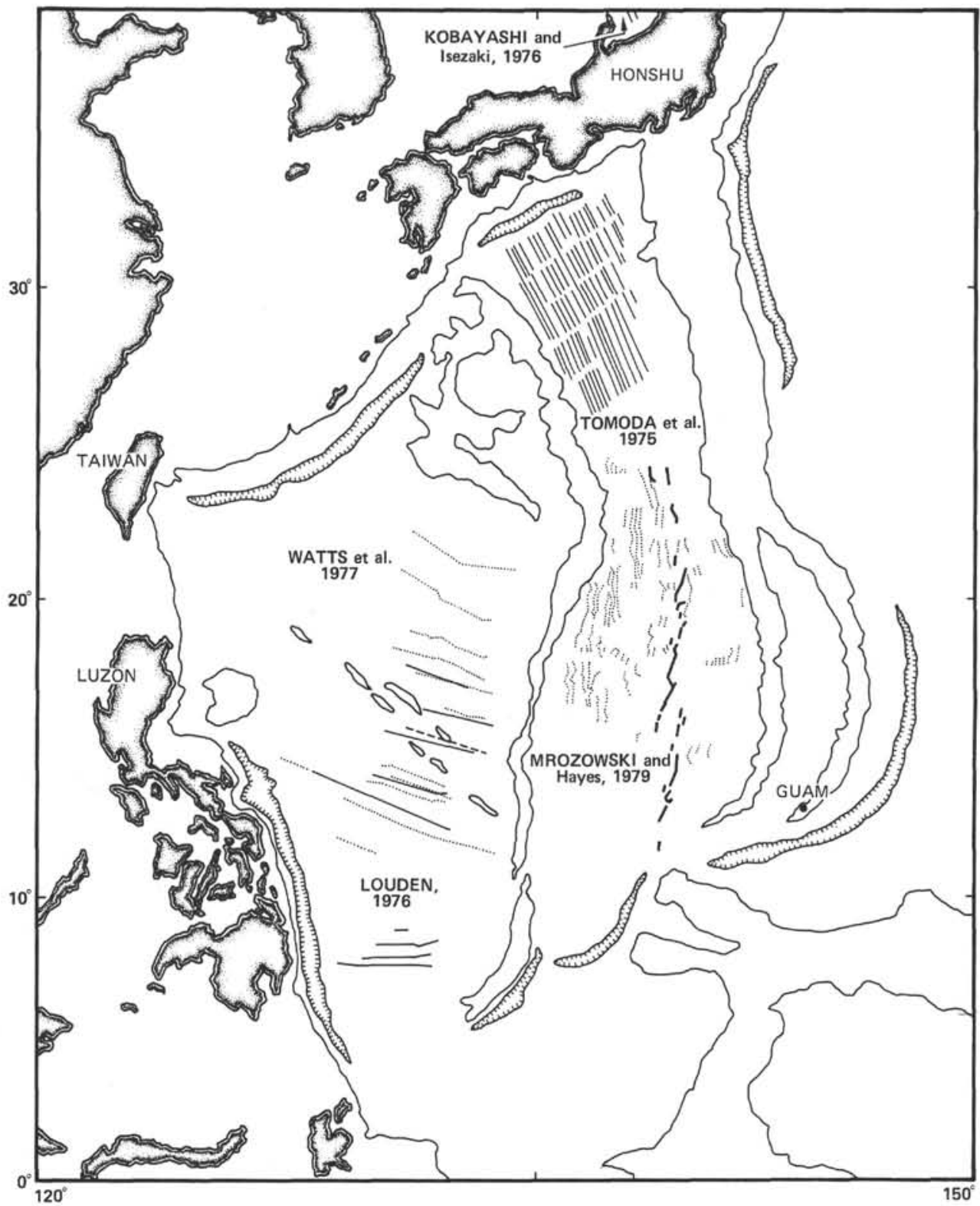

Figure 13. Magnetic-anomaly patterns in the West Philippine Basin (Watts et al., 1977; Louden, 1976), the Shikoku Basin (Tomoda et al., 1975), and the Parece Vela Basin (Mrozowski and Hayes, 1979).

impedance. Methods and procedures for the measurement and determination of physical properties on board the Glomar Challenger have been previously described by Boyce (1976) and are briefly summarized in the Introduction (this volume). The results are listed in Table 8 and shown graphically in Figure 14.

Whereas drilling disturbances in the first 47 meters (Cores 1-5) precluded reliable sonic-velocity measurements, velocities were measured on selected samples between 47 and 295 meters sub-bottom (Cores 6-36). Between 0 and approximately 110 meters sub-bottom, apparent wet-bulk density was obtained by the continuous analog GRAPE method; from 110 to 295 meters, special 2-minute GRAPE measurements had to be obtained from individual samples. In order to facilitate comparison, in Figure 14, densities determined by the GRAPE method (using a grain density of $2.75 \mathrm{~g} / \mathrm{cm}^{3}$ ) are plotted along with those determined by the gravimetric method. Water content and porosity were determined for only a few samples between 47 and 104 meters sub-bottom (Cores 6-12).

Sonic velocities increase with depth and lithification, ranging from $1.95 \mathrm{~km} / \mathrm{s}$ to $2.52 \mathrm{~km} / \mathrm{s}$ in Cores 6 through 10. A slight anistropy between vertical velocities (measured perpendicular to bedding) and horizontal velocities (measured parallel to bedding) was also observed. A large increase in sonic velocity occurs between the bottom of Core 10 and the top of Core 14 (94.5-113 m, sub-bottom). Velocities of 4.59 and 3.59 $\mathrm{km} / \mathrm{s}$ characterized the volcaniclastic breccia and tuff, respectively. In the basalt encountered below Core 13, sonic velocities range from $<4$ to $>6 \mathrm{~km} / \mathrm{s}$. The lowest velocities are associated with pillow basalt layers and intensely fractured and weathered zones: the highest 
Table 7. NRM results for Hole 447A.

\begin{tabular}{|c|c|c|c|c|c|}
\hline $\begin{array}{l}\text { Lithologic Unit } \\
\text { or Sub-unit } \\
\text { (mean inclination } \\
\text { in }{ }^{\circ} \text { ) }\end{array}$ & $\begin{array}{c}\text { Sample } \\
\text { (core-section, } \\
\text { depth in } \\
\text { interval in } \mathrm{cm} \text { ) }\end{array}$ & $\begin{array}{l}\text { Depth } \\
\text { (m) }\end{array}$ & $\begin{array}{l}\text { Inclination } \\
\left({ }^{\circ}\right)\end{array}$ & $\begin{array}{c}\text { Declination } \\
\left({ }^{\circ}\right)\end{array}$ & $\begin{array}{l}\text { Intensity } \\
\left(\mathrm{emu} / \mathrm{cm}^{3}\right)\end{array}$ \\
\hline & $\begin{array}{l}5-2,76 \\
6-7,39 \\
10-1,105 \\
10-2,49 \\
10-2,121\end{array}$ & $\begin{array}{l}39.26 \\
56.39 \\
86.05 \\
86.99 \\
87.71\end{array}$ & $\begin{array}{r}-13.88 \\
-0.83 \\
45.66 \\
53.92 \\
-73.60\end{array}$ & $\begin{array}{r}210.78 \\
296.87 \\
37.08 \\
229.86 \\
164.80\end{array}$ & $\begin{array}{l}0.1041 \times 10^{-3} \\
0.1337 \times 10^{-3} \\
0.1126 \times 10^{-3} \\
0.1648 \times 10^{-3} \\
0.3420 \times 10^{-4}\end{array}$ \\
\hline \multirow{3}{*}{$\begin{array}{c}6 \\
(9.5)\end{array}$} & $\begin{array}{l}14-1,39 \\
14-1,90 \\
14-2,53 \\
14-2,107 \\
14-2,123\end{array}$ & $\begin{array}{l}113.39 \\
113.90 \\
115.03 \\
115.57 \\
113.73\end{array}$ & $\begin{array}{r}-13.00 \\
6.16 \\
14.10 \\
-14.60 \\
-3.19\end{array}$ & $\begin{array}{r}39.50 \\
71.29 \\
264.60 \\
87.40 \\
94.11\end{array}$ & $\begin{array}{l}0.3573 \times 10^{-4} \\
0.3146 \times 10^{-3} \\
0.1721 \times 10^{-3} \\
0.1424 \times 10^{-3} \\
0.2736 \times 10^{-1}\end{array}$ \\
\hline & $\begin{array}{l}14-3,29 \\
14-3,64 \\
14-3,88 \\
15-1,58 \\
15-2,72\end{array}$ & $\begin{array}{l}116.29 \\
116.64 \\
116.88 \\
122.58 \\
124.22\end{array}$ & $\begin{array}{r}-13.80 \\
-1.20 \\
-8.10 \\
2.00 \\
6.00\end{array}$ & $\begin{array}{r}39.80 \\
286.10 \\
89.80 \\
146.80 \\
182.80\end{array}$ & $\begin{array}{l}0.2384 \times 10^{-4} \\
0.5216 \times 10^{-4} \\
0.1736 \times 10^{-4} \\
0.2024 \times 10^{-4} \\
0.3912 \times 10^{-4}\end{array}$ \\
\hline & $\begin{array}{l}15-2,130 \\
15-4,5 \\
16-1,11\end{array}$ & $\begin{array}{l}124.80 \\
126.55 \\
131.11\end{array}$ & $\begin{array}{r}-4.13 \\
-9.5 \\
-28.70\end{array}$ & $\begin{array}{r}157.76 \\
89.90 \\
359.00\end{array}$ & $\begin{array}{l}0.3936 \times 10^{-2} \\
0.2023 \times 10^{-3} \\
0.2500 \times 10^{-4}\end{array}$ \\
\hline $7(10.2)$ & $\begin{array}{l}16-2,24 \\
17-1,31\end{array}$ & $\begin{array}{l}132.74 \\
140.31\end{array}$ & $\begin{array}{r}10.90 \\
-9.50\end{array}$ & $\begin{array}{r}147.40 \\
83.20\end{array}$ & $\begin{array}{l}0.7672 \times 10^{-3} \\
0.3911 \times 10^{-3}\end{array}$ \\
\hline \multirow{4}{*}{$\begin{array}{c}8 \\
(14.5)\end{array}$} & $\begin{array}{l}17-3,89 \\
18-2,98 \\
18-3,20 \\
19-2,113 \\
19-3,40\end{array}$ & $\begin{array}{l}143.89 \\
151.48 \\
152.20 \\
154.63 \\
155.40\end{array}$ & $\begin{array}{r}-5.30 \\
-5.11 \\
-76.00 \\
-1.69 \\
-4.07\end{array}$ & $\begin{array}{r}87.10 \\
254.54 \\
248.30 \\
351.67 \\
255.76\end{array}$ & $\begin{array}{l}0.3228 \times 10^{-1} \\
0.1004 \times 10^{-2} \\
0.5320 \times 10^{-4} \\
0.2203 \times 10^{-2} \\
0.3240 \times 10^{-2}\end{array}$ \\
\hline & $\begin{array}{l}19-3,122 \\
20-1,76 \\
20-2,115 \\
20-3,48 \\
21-1,10\end{array}$ & $\begin{array}{l}156.22 \\
158.76 \\
160.65 \\
161.48 \\
167.10\end{array}$ & $\begin{array}{r}-0.16 \\
-15.04 \\
-7.06 \\
59.00 \\
-8.14\end{array}$ & $\begin{array}{r}53.86 \\
72.90 \\
55.91 \\
290.10 \\
115.37\end{array}$ & $\begin{array}{l}0.2018 \times 10^{-2} \\
0.3054 \times 10^{-2} \\
0.2989 \times 10^{-2} \\
0.3840 \times 10^{-3} \\
0.2602 \times 10^{-2}\end{array}$ \\
\hline & $\begin{array}{l}21-1,73 \\
21-2,109 \\
21-4,110 \\
21-5,71 \\
22-1,83\end{array}$ & $\begin{array}{l}167.73 \\
169.59 \\
172.60 \\
173.71 \\
176.83\end{array}$ & $\begin{array}{r}-15.58 \\
-8.60 \\
-11.37 \\
-2.73 \\
-9.51\end{array}$ & $\begin{array}{r}176.81 \\
342.10 \\
48.20 \\
160.89 \\
55.46\end{array}$ & $\begin{array}{l}0.2738 \times 10^{-2} \\
0.2546 \times 10^{-2} \\
0.2844 \times 10^{-2} \\
0.2117 \times 10^{-2} \\
0.3172 \times 10^{-2}\end{array}$ \\
\hline & $\begin{array}{l}22-3,19 \\
23-1,5 \\
24-2,76\end{array}$ & $\begin{array}{l}179.19 \\
180.05 \\
187.26\end{array}$ & $\begin{array}{r}-8.07 \\
-11.11 \\
13.19\end{array}$ & $\begin{array}{r}264.85 \\
138.50 \\
19.26\end{array}$ & $\begin{array}{l}0.7064 \times 10^{-2} \\
0.3080 \times 10^{-2} \\
0.6052 \times 10^{-2}\end{array}$ \\
\hline $9(14.8)$ & $\begin{array}{l}25-1,92 \\
25-3,8\end{array}$ & $\begin{array}{l}191.92 \\
194.08\end{array}$ & $\begin{array}{r}16.62 \\
-2.00\end{array}$ & $\begin{array}{r}203.61 \\
0.10\end{array}$ & $\begin{array}{l}0.3367 \times 10^{-2} \\
0.4230 \times 10^{-2}\end{array}$ \\
\hline $\begin{array}{c}10 \\
(17.6)\end{array}$ & $\begin{array}{l}26-1,67 \\
26-3,50 \\
26-3,78 \\
27-1,76 \\
28-1,76\end{array}$ & $\begin{array}{l}199.17 \\
202.00 \\
202.28 \\
208.26 \\
217.26\end{array}$ & $\begin{array}{r}14.68 \\
0.65 \\
5.84 \\
-65.20 \\
53.16\end{array}$ & $\begin{array}{l}121.02 \\
348.22 \\
114.13 \\
194.00 \\
206.36\end{array}$ & $\begin{array}{l}0.3479 \times 10^{-2} \\
0.2035 \times 10^{-2} \\
0.2239 \\
0.2319 \times 10^{-1} \\
0.1730 \times 10^{-2}\end{array}$ \\
\hline $\begin{array}{c}11 \mathrm{a}-11 \mathrm{~d} \\
(51.5)\end{array}$ & $\begin{array}{l}29-2,74 \\
29-4,93 \\
29-5,8 \\
30-1,53 \\
30-4,70\end{array}$ & $\begin{array}{l}227.74 \\
230.93 \\
231.58 \\
235.03 \\
239.70\end{array}$ & $\begin{array}{r}48.36 \\
48.06 \\
46.06 \\
-64.40 \\
49.31\end{array}$ & $\begin{array}{r}233.64 \\
93.14 \\
72.57 \\
308.80 \\
315.67\end{array}$ & $\begin{array}{l}0.1734 \times 10^{-2} \\
0.2425 \times 10^{-2} \\
0.8849 \times 10^{-3} \\
0.6267 \times 10^{-3} \\
0.2382 \times 10^{-2}\end{array}$ \\
\hline $\begin{array}{c}11 \mathrm{e} \\
(18.5)\end{array}$ & $\begin{array}{l}31-3,142 \\
31-4,17 \\
32-1,103 \\
32-3,5 \\
34-1,59 \\
34-2,109\end{array}$ & $\begin{array}{l}247.92 \\
248.17 \\
253.53 \\
255.55 \\
271.09 \\
273.09\end{array}$ & $\begin{array}{r}19.70 \\
25.20 \\
20.62 \\
19.32 \\
-15.34 \\
-11.17\end{array}$ & $\begin{array}{l}205.80 \\
128.17 \\
153.25 \\
328.41 \\
135.87 \\
248.27\end{array}$ & $\begin{array}{l}0.2975 \times 10^{-3} \\
0.4388 \times 10^{-2} \\
0.3095 \times 10^{-2} \\
0.3585 \times 10^{-2} \\
0.3795 \times 10^{-2} \\
0.2842 \times 10^{-2}\end{array}$ \\
\hline
\end{tabular}

velocities are correlated with dense basalt flows and fresh basalt. The highest values of $>6.0 \mathrm{~km} / \mathrm{s}$ were measured in a coarse-grained basalt (dolerite) flow in Sections 24-3 and 25-1.

Down-core in the poorly lithified polymictic breccia conglomerate, water content ranges from $48 \%$ to $31 \%$, whereas porosity ranges from $70 \%$ to $53 \%$. A large increase in wet-bulk densities occurs between Cores 10 and 14 in the volcaniclastic breccia and tuff. In the basalts, the values range from around $2.6 \mathrm{~g} / \mathrm{cm}^{3}$ in altered areas to more than $2.9 \mathrm{~g} / \mathrm{cm}^{3}$ in fresh zones.

\section{GEOPHYSICS}

Although much has been written on the origin of the seafloor in the South Philippine Sea, the geophysical data that have provided the basis for much of the past speculation have been, in reality, very sparse. Recently, some researchers have proposed an early Tertiary or older age for the formation of the West Philippine Basin by seafloor spreading, based on the magnetic-anomaly pattern (Louden, 1976; Watts et al., 1977). Although Watanabe et al. (1977) note that sample size and distribution are not ideal, they report that average heatflow values appear to be significantly higher than that predicted for a basin this age (as young as $41 \mathrm{~m}$.y. [Louden, 1976] or older than 50 m.y. [Karig, 1975]). Likewise, the reported heat flow is significantly higher than would be expected for the great depth of the West Philippine Basin, approximately $6000 \mathrm{~m}$ below sea level (Sclater et al., 1976). And finally, Seekins and Teng (1977) have concluded, based on surface-wave analysis, that the lithosphere under the entire South Philippine Sea is thin, "on the order of $30 \mathrm{~km}$," and is underlain by a low-velocity mantle.

Karig (1974) has also suggested that the crust in the West Philippine Basin is thin. Seismic-refraction measurements reported by Murauchi et al. (1968), however, do not seem to suggest abnormally thin crust in the South Philippine Sea region. Reversed refraction lines in the South Philippine Sea are rare and, in particular, those located in the West Philippine Basin are not as suggestive of thin crust as those from other parts of the South Philippine Sea. The seismic-refraction data do indicate, however, a widespread, almost ubiquitous 3.5$\mathrm{km} / \mathrm{s}$, low-velocity Layer 2a. In fact, the apparent absence of this layer in one area ultimately determined the location of Site 447 (see Background and Objectives, this chapter).

As was mentioned earlier, the close resemblance of the reflection profile recorded on board the Glomar Challenger (during the approach to the drill site) to the profile taken during the L-DGO Site Survey enabled deployment of the beacon on the Challenger's initial pass over the drill site. That profile (shown in Fig. 4) reveals a somewhat nonuniform or variable sediment distribution, with transparent sediments ranging in thickness from less than $0.1 \mathrm{~s}$ to more than $0.3 \mathrm{~s}$ reflection time, effectively attenuating the relief of a blockfaulted basement through infilling of fault valleys. The sediment thus appears to be accumulating or ponding in elongated basement lows trending west-northwest (Fig. 2).

Correlation of drilling results with the reflection profile taken across Site 447 is shown in Figure 15. Sediment thickness of slightly more than $0.1 \mathrm{~s}$ reflection time is observed in the vicinity of the site. Although several weak reflectors may be present above acoustic basement, the only reflection that can be identified with any certainty and correlated with the drilling results is the strong low-frequency reflection occurring at $0.12 \mathrm{~s}$ reflection time, thought to be caused by basaltic basement. This interpretation gives an average velocity of $1.8 \mathrm{~km} / \mathrm{s}$ for the sediment, which seems reasonable, based on estimated velocities for the upper half of the sedimentary column and the measured velocities in the lower half of the column at Site 447. 
Table 8. Physical properties of sediments and igneous rocks from Hole 447A.

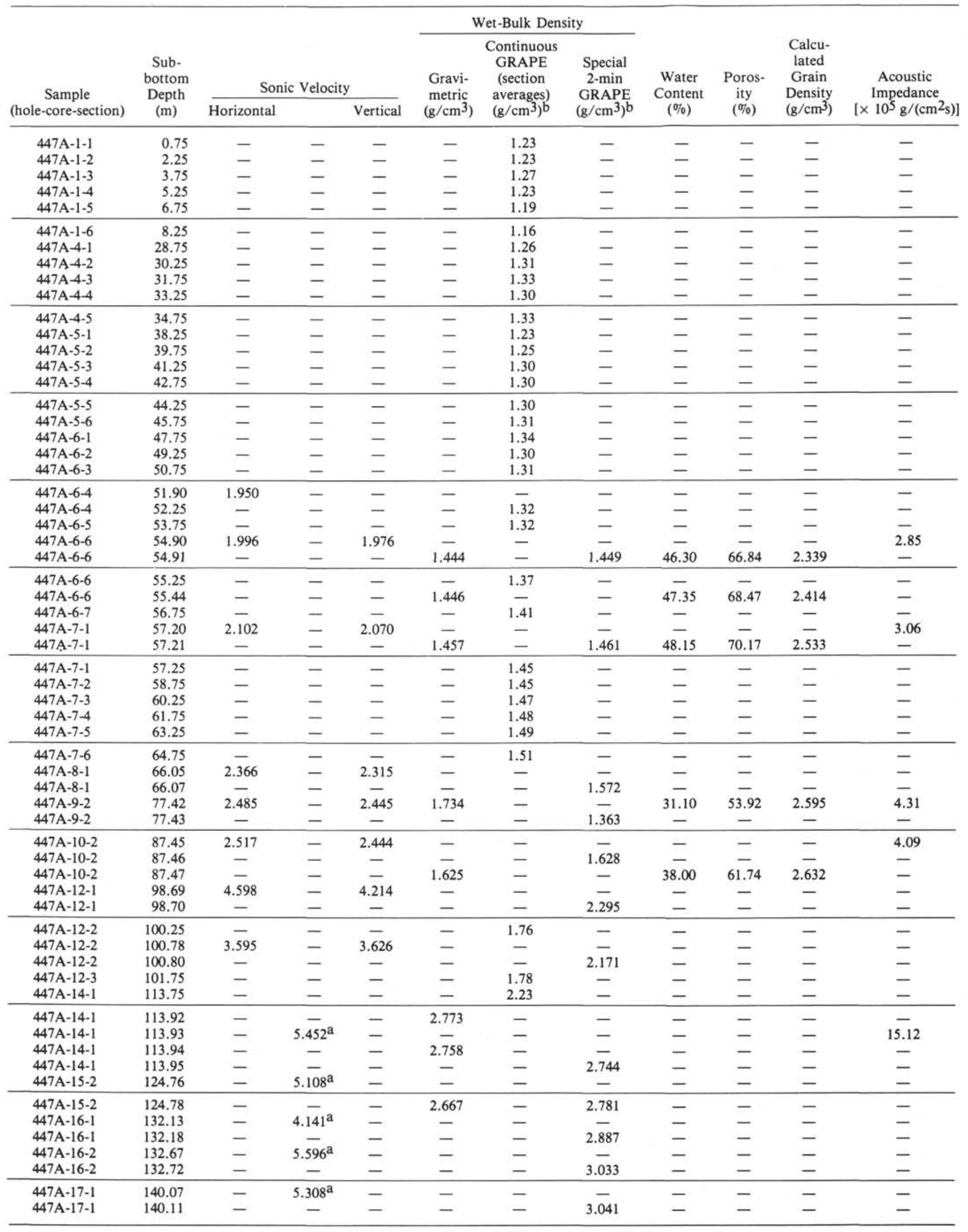


Table 8. (Continued).

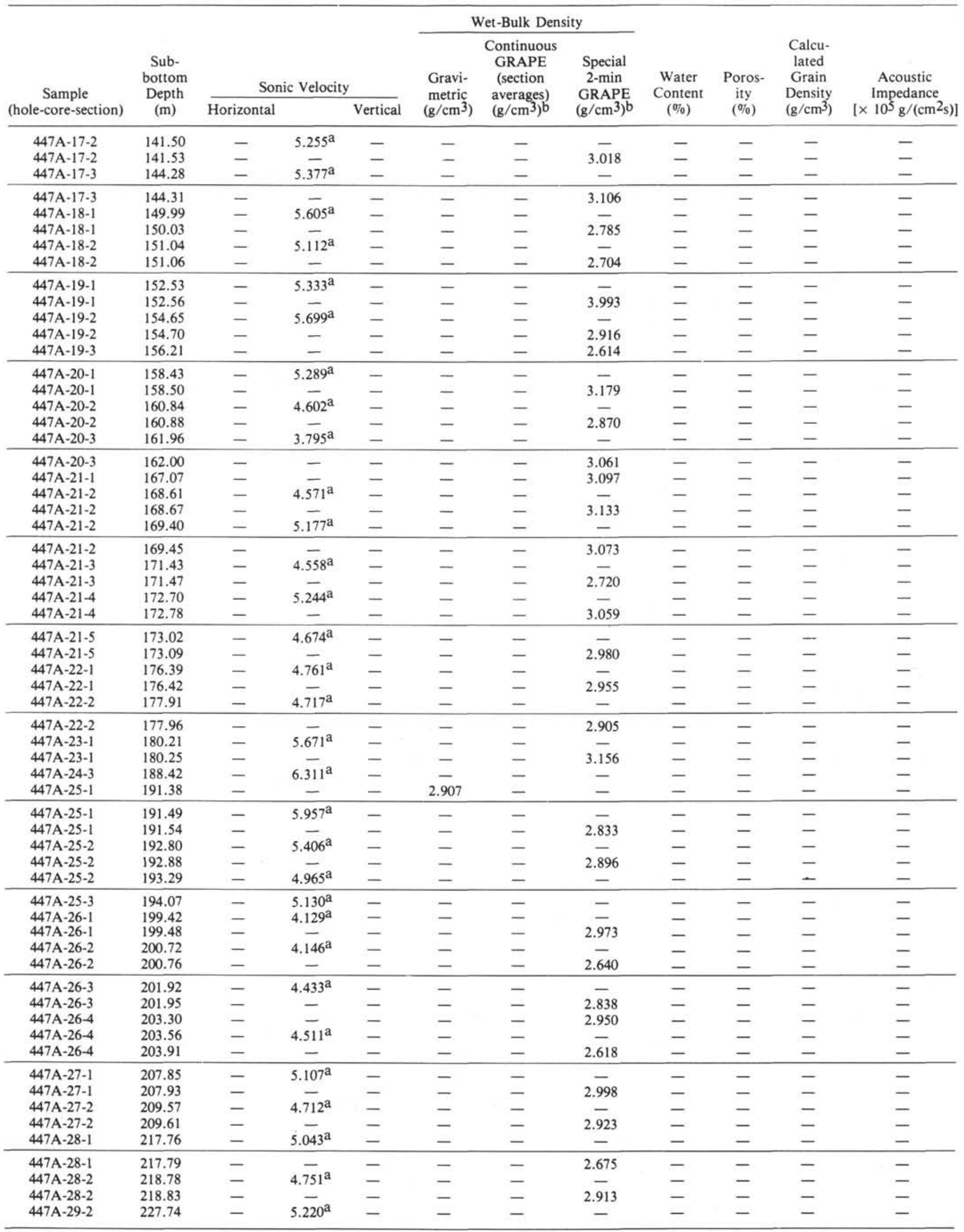


Table 8. (Continued).

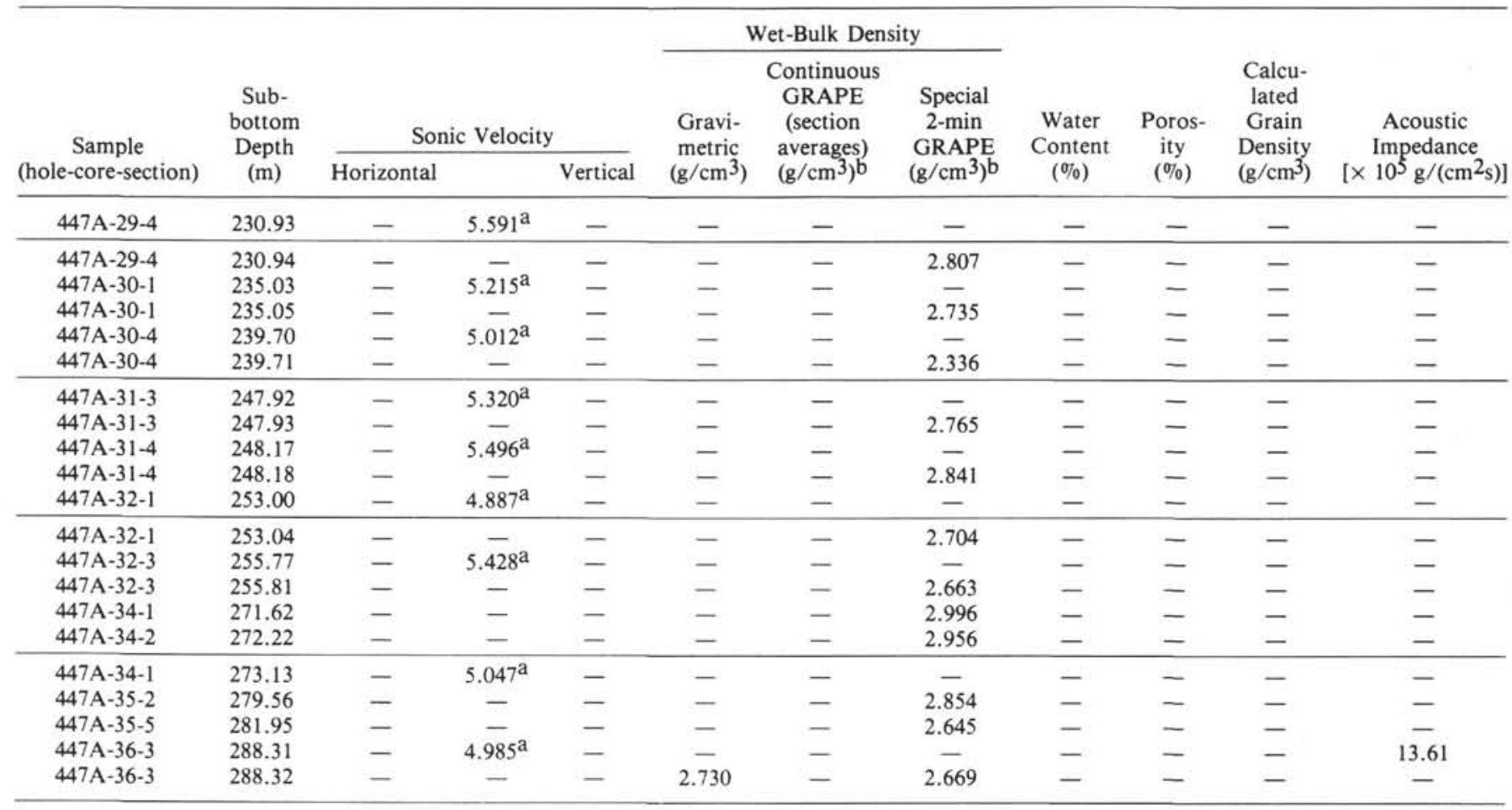

a Basalt average velocity.

b Based on an assumed grain density of $2.75 \mathrm{~g} / \mathrm{cm}^{3}$.

Acoustic Impedance Sonic Velocity

Wet-Bulk Density

Porosity

Grain Density

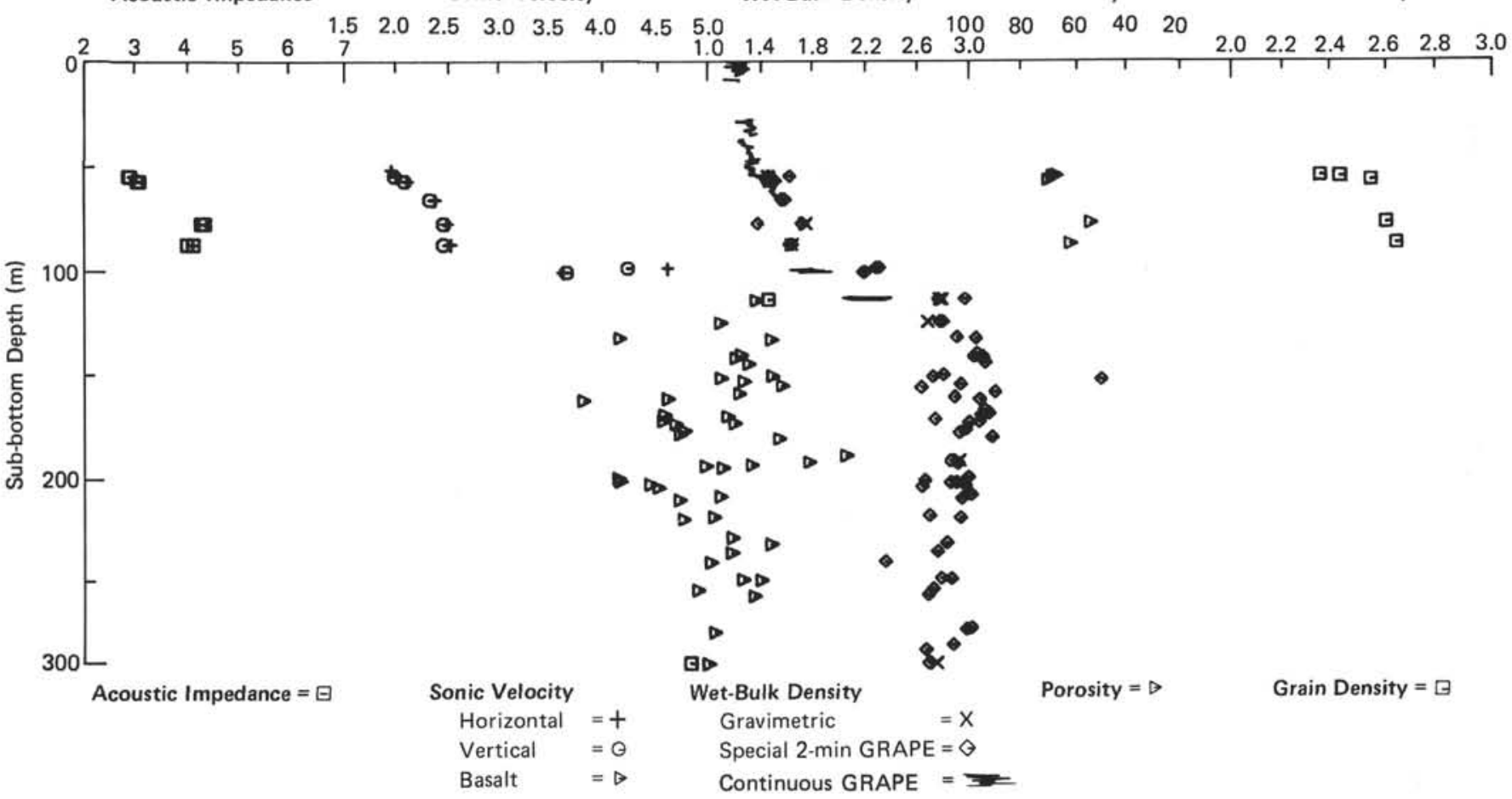

Figure 14. Physical properties of sedimentary and igneous rocks from Hole 447A plotted versus sub-bottom depth in meters. Acoustic impedance is the product of velocity and bulk density. Sonic-velocity measurements include horizontal and vertical velocity of sediments and average velocity of basalts. Gravimetric determinations of wet-bulk density are shown. Special 2-minute and continuous GRAPE determinations of wet-bulk density are also shown, based on an assumed grain density of $2.75 \mathrm{~g} / \mathrm{cm}^{3}$. Porosity was determined gravimetrically, and grain density was calculated from porosity and bulk density. 


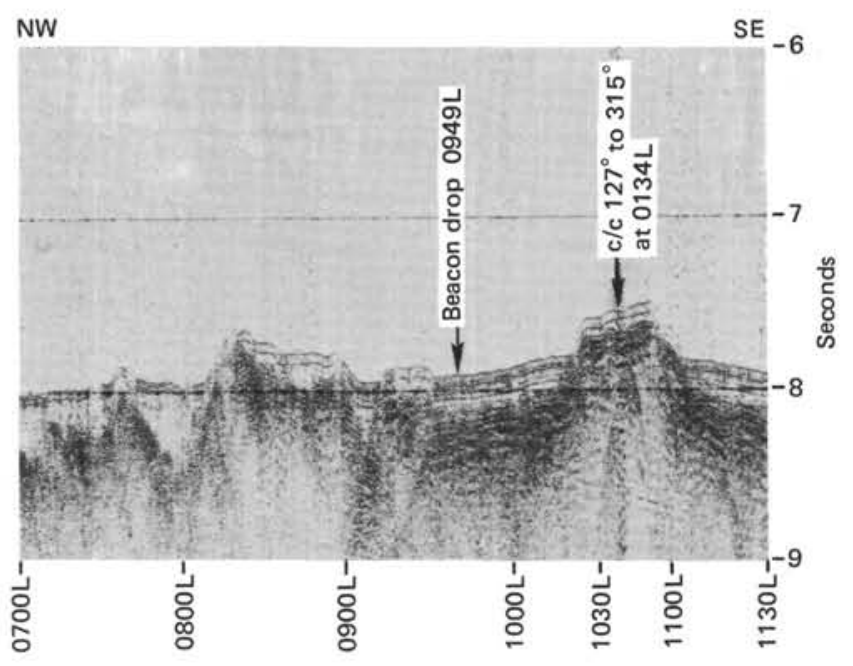

Figure 15. Seismic-reflection profile across Site 447 recorded on board the Glomar Challenger during approach to the site.

\section{SUMMARY AND CONCLUSIONS}

Site 447 at $18^{\circ} 00.88^{\prime} \mathrm{N}$ and $133^{\circ} 17.37^{\prime} \mathrm{E}$ was chosen with the objective of determining the nature and age of the West Philippine Basin basement. Continuous coring resulted in a total recovery of 155 meters out of 296.5 meters drilled. Sediments were cored to a depth of 113 meters, at which point igneous basement was encountered. Basement was penetrated and cored another 183.5 meters to a total depth of 296.5 meters subbottom. The sedimentary section is lithologically divided into five lithologic units that range from the early Miocene to the middle Oligocene. The basement section is divided into six extrusive units based upon phenocryst assemblages.

The sedimentary section consists of:

Unit $1(0-37.5 \mathrm{~m})$, lower Miocene, dark-brown pelagic clay.

Unit $2(37.5-47.0 \mathrm{~m})$, upper middle to lower upper Oligocene, yellow-brown calcareous pelagic clay.

Unit $3(47.0-85.0 \mathrm{~m})$, incorporating two sub-units:

Sub-unit 3a (47.0-66.0 m), middle to lower upper Oligocene, olive-brown to light yellow-brown polymictic conglomerate; and

Sub-unit 3b (66.0-85.0 m), middle Oligocene, dark olive-gray polymictic breccia.

Unit $4(85.0-87.1 \mathrm{~m})$, barren, variegated gray, brown, and olive altered fine tuff.

Unit 5 (87.1-113.0 m), incorporating three sub-units:

Sub-unit 5a (87.1-99.6 m), middle Oligocene, grayish green volcaniclastic breccia with a tuff layer near its top;

Sub-unit 5b (99.6-104.0 m), middle Oligocene, yellowish brown tuff; and

Sub-unit 5c (104.0-113.0 m), barren, yellow-brown volcaniclastic breccia.

The basement consists of:

Unit $6(113.0-131.0 \mathrm{~m})$, plagioclase-phyric tholeiitic basalts incorporating four sub-units representing individual cooling units:

Sub-unit 6a (113.0-115.0 m), massive basalt flow;
Sub-unit 6b (115.0-123.0 m), pillow lava basalt flow; Sub-unit 6c (123.0-125.0 m), pillowed massive basalt flow; and

Sub-unit 6d (125.0-131.5 m), pillowed massive basalt flow.

Unit 7 (131.5-141.0 m), plagioclase-phyric pillow lava basalt flow

Unit $8(141.0-185.0 \mathrm{~m})$, plagioclase-clinopyroxeneolivine-phyric tholeiitic basalt incorporating four subunits representing individual cooling units:

Sub-unit 8a (141.0-154.5 m), pillowed massive basalt flow;

Sub-unit 8b (154.5-167.0 m), pillowed massive basalt flow;

Sub-unit 8c (167.0-170.5 m), pillowed massive basalt flow; and

Sub-unit 8d (170.5-185.0 m), pillowed massive basalt flow with a doleritic base.

Unit 9 (185.0-194.0 m), aphyric to olivine-spinelphyric massive doleritic flow.

Unit $10(194.0-209.0 \mathrm{~m})$, plagioclase-olivine-clinopyroxene-phyric tholeiitic basalt incorporating two subunits representing individual cooling units:

Sub-unit 10a (194-203.5 m), pillowed massive basalt flow; and

Sub-unit 10b (203.5-209.0 m), pillowed massive basalt flow with a doleritic base.

Unit 11 (209.0-296.5 m), plagioclase-olivine-spinelphyric tholeiitic basalt incorporating six sub-units representing individual cooling units:

Sub-unit 11a (209.0-228.5 m), pillowed massive basalt flow;

Sub-unit 11b (228.5-235.0 m), pillowed massive basalt flow;

Sub-unit 11c (235.0-239.5 m), pillowed massive basalt flow;

Sub-unit 11d (239.5-247.0 m), pillow lava basalt flow;

Sub-unit 11e (247.0-282.0 m), pillow lava basalt flow; and

Sub-unit 11f (282.0-296.5 m), pillow lava basalt flow with large gabbroic xenocrysts and an anorthositic cumulate xenolith.

Based on ichthyoliths (fish teeth), sediments in the core catchers of Core 1 in both Holes 447 and 447A have been identified as dating from the early Miocene. Although they are fairly abundant and well preserved in Core 1 of $447 \mathrm{~A}$, ichthyoliths are rare lower in the dark brown pelagic clay of Unit 1 . Unit 2 is assigned to the late middle to early late Oligocene based upon nannoplanktons of Zone NP 24. Sub-unit 3a is assigned to the middle to early late Oligocene based upon nannoplanktons of both Zones NP 23 and NP 24. Sub-unit $3 \mathrm{~b}$ through Unit 5 are assigned to the middle Oligocene based only upon nannoplanktons of Zone NP 23. Except for the barren intervals between 85.0 and 94.5 meters (Unit 4 and upper Sub-unit 5a) and between 104.0 and 113.0 meters (Sub-unit 5c), the specimens are poorly preserved and heavily etched. No diatoms or silicoflagellates were found in Hole 447A samples. Extremely rare radiolarians were found but were too non- 
diagnostic or too fragmentary for positive identification. In core-catcher samples collected at the bases of Units 5 and 2, displaced, rare, lower Oligocene nannoplankton were identified within middle to lower upper Oligocene strata, indicating probable erosion of older deposits. Because nannoplanktons can readily be retransported great distances after erosion, the provenance of eroded older deposits is speculative.

Accumulation rates during deposition of the 37.5 meters of the brown pelagic clay were low; if the early Miocene estimation is correct, then a minimum rate of about $2 \mathrm{~m} / \mathrm{m}$.y. is reasonable for Unit 1 . Between 37.5 meters and 113.0 meters sub-bottom, obviously one continuous rate of deposition cannot be derived within clays, conglomerates, breccias, and tuffs, particularly with only one nannoplankton zone boundary (NP $23 / 24$ ). In fact, some of these units may have been deposited essentially instantaneously relative to geologic rates. It is probable that the rates of accumulation for the breccias and tuffs of Units 3, 4, and 5 were far greater than those for the calcareous pelagic clays of Unit 2. Furthermore, it is possible that one or more stratigraphic breaks exist in Site 447 even though no positive evidence for a hiatus was found. Because the age of the upper portion of Core 1 has not been established with any degree of certainty, it is possible that one or more unidentified stratigraphic breaks may exist in the section. Likewise, a hiatus may exist at the igneous basement/sedimentary contact.

Because the core catcher of Core 1 in Hole 447 contained abundant ferromanganese nodules and crusts and the tops of cores in Hole 447A commonly had ferromanganese nodules that probably had fallen from the surface during drilling, a ferromanganese-nodule pavement is inferred for this area. Down-core in the dark brown pelagic clay of Unit 1, the zeolite content increases systematically from traces to $10 \%$. Color changes are mainly the result of variations in abundance (up to 10\%) of ferromanganese micronodules and ironoxide aggregates. A decrease (5\% to trace) of ferromanganese micronodules and iron-oxide down-core in Unit 2 also results in color changes (from dark yellow-brown at the top to light yellow-brown at the base). Although the top of Sub-unit $3 \mathrm{a}$ contains the uppermost volcanic debris, consisting of highly altered pumice or basalt clasts and glass fragments mixed with roughly equal parts of nannofossil chalk and clay minerals, the bottom of Sub-unit 3b contains only rare volcanic debris and is composed of more than $50 \%$ clay. Within the polymictic breccia of Sub-unit $3 \mathrm{~b}$, an increase in volcanic and sedimentary clasts occurs down-core, with rounded sedimentary clasts dominating near the base of the unit. In the highly altered, variegated fine tuffs of Unit 4, ferromanganese micronodules comprise $10 \%$ of the unit, and clay minerals, zeolite, and potassium feldspar comprise the rest of the material. In Unit 5, the uppermost sub-unit (5a) has a greenish black tuff near its top, whereas its lower part consists of angular, fresh to weathered basalt clasts in a fine-grained matrix of glass $(73 \%)$ and carbonate $(27 \%)$. The middle sub-unit (5b) shows an upward coarsening from medium-grained sands at the base to coarser sands to angular gravel at the top. The lowermost sub-unit $(5 \mathrm{c})$ consists of very angular basaltic clasts, some greater than the $6.6-\mathrm{cm}$ core diameter. A weathered zone was absent from the top of the igneous basement. The basalt at the contact between igneous basement and the overlying Sub-unit 5c breccias does not contain evidence of distinctive weathering.

Excellent core recovery of the basalts, including glassy margins, makes it possible to recognize three types of flows or cooling units: (1) single massive flows; (2) pillow lava flows, which may consist of one or more cooling units; and (3) pillowed massive flows with pillow lava tops and massive flow bases. Massive flows are between 2 and 9.5 meters thick, and average 6 meters thick. Individual pillows vary between 0.1 and 1.4 meters thick and average 0.55 meters thick.

Both the phenocryst mineralogy and the X-ray fluorescence (XRF) data indicate that these basalts are all indistinguishable from tholeiitic mid-ocean ridge basalts. The presence of gabbroic xenocrysts and the anorthositic cumulate xenolith in the basal unit cored suggests that these inclusions were removed from a lower cumulate magma chamber by repeated pulses of fresh magma injection.

No evidence for hydrothermal metamorphism or hydrothermal vein formation exists in the basalts. However, low-temperature alteration of basaltic rocks is common. Radial cooling fractures are filled with veins of brown and green smectites, carbonates, and zeolites. Vesicles are also filled with these minerals, and the altered groundmass and phenocrysts exhibit this mineral suite.

Structural deformation at Site 447 is indicated by a 1.5-meter-thick fault zone that cuts through Unit 9 at approximately a $60^{\circ}$ dip. Although the central part of the zone consists of rubble, the margins show distinct high-angle fracture patterns suggestive of extensional faulting, which is in turn suggestive of block faulting of basement rocks.

The average paleolatitude calculated for this site is $10.5^{\circ}$; thus either a $7.5^{\circ}$ or a $28.5^{\circ}$ northward migration is suggested, depending upon whether a north or south paleolatitude position for the West Philippine Basin is proposed. No polarity histories can be attempted at these low latitudes because apparent reversals (due to normal secular variations) and true reversals cannot be distinguished.

As would be expected, seismic velocities increase with depth and lithification. Velocities increase from 1.95 $\mathrm{km} / \mathrm{s}$ to $2.52 \mathrm{~km} / \mathrm{s}$ between Cores 6 and 10. Below Core 10 , velocities reach values of 3.59 and $4.59 \mathrm{~km} / \mathrm{s}$ in the tuffs and volcaniclastic breccias. Within the basement, velocities range from $<4$ to $>6.0 \mathrm{~km} / \mathrm{s}$, with lower values characterizing pillow basalts, fractured zones, and weathered horizons and higher values characterizing doleritic bases of fresh massive flows. 
From the relationships discussed earlier, the sequence of events at Site 447 from oldest to youngest can be summarized as follows:

1) Tholeiitic flows and pillow lavas formed the basement of the West Philippine Basin at Site 447 in or prior to the middle Oligocene.

2) Between the time of accumulation of the lavas and the present, the region migrated from either $10.5^{\circ}$ south or $10.5^{\circ}$ north to $18^{\circ}$ north.

3) Coarse volcaniclastic breccias and tuffs of Subunits $5 \mathrm{c}$ and $5 \mathrm{~b}$ were deposited below or close to the CCD. Local tectonism is indicated by the deposition of angular basaltic clasts of Sub-unit 5c, which are very similar to the underlying basalts; these breccias are similar to those observed in talus from fault scarps along modern mid-ocean ridge rift-valley walls. An upward coarsening began in the tuffs of Sub-unit $5 b$ and ended in the volcaniclastic breccias of the lower part of Sub-unit 5a; this may indicate a renewal or second period of tectonic uplift.

4) Sediments of the upper part of Sub-unit 5a became finer upward and were interrupted by the deposition of the fine altered tuffs of Unit 4. A possible interpretation may be a temporary slackening in local tectonism coinciding with a pulse of arc volcanism.

5) A coarsening of sediments occurred again during deposition of Sub-unit 3b. At this time, rounded sedimentary clasts began to appear and gradually became dominant over angular volcanic clasts. Also at this time, reworked lower-Oligocene nannoplankton were mixed with middle-Oligocene fauna. This suggests that more distant and older sedimentary rocks were being eroded. Apparently the site of deposition was at this point above the $C C D$ and remained above the $C C D$ throughout deposition of Sub-unit $3 \mathrm{a}$ and Unit 2.

6) Volcanic contribution from the arc to the sediments of Site 447 decreased during deposition of Subunit $3 \mathrm{a}$. Thus by the late middle Oligocene to the early late Oligocene, both volcanic influence on and tectonic control of sedimentation ceased.

7) A quiescent period of deep-water accumulation of calcareous pelagic clay took place during the late Oligocene deposition of Unit 2.

8) In the Miocene, submergence of the region again below the $C C D$, restricted sediment accumulation to a zeolitic brown pelagic clay.

9) Further restriction occurred sometime between early Miocene and Recent, as is indicated by the development of the ferromanganese-nodule pavement near the top of Unit 1.

After the completion of drilling at Site 447, new constraints on the type and timing of the geodynamic processes involved in the formation of the West Philippine Basin were evident. For example, a continuous sequence of uninterrupted normal oceanic tholeiitic basalt flows and pillow lavas with no intervening sediments is consonant with development of a normal oceanic type of basement. No evidence for the occurrence of any sills, dikes, or subsediment flows within the sedimentary sequence was observed. If no significant hiatus exists between formation and sediment accumulation, then the age of the igneous basement beneath the middle Oligocene sediments would be close to middle Oligocene. On the other hand, if a significant hiatus exists, then igneous basement could be much older. The presence of lower Oligocene reworked fossils, possibly derived from a distant source, requires that older sediment existed somewhere in the region prior to the deposition of the middle-Oligocene breccias. Similarly, Eocene reworked fossils were reported to have been derived from a source nearby DSDP Site 290 (Karig, Ingle, et al., 1975). The presence of locally derived middle Oligocene volcaniclastic breccias and polymictic sedimentary conglomerates and breccias containing reworked fossils requires a nearby source of sediment during several periods of tectonism. The presence of volcanic-arc type of debris deposited during the middle to early late Oligocene requires active arc volcanism in the vicinity.

\section{REFERENCES}

Ben-Avraham, Z., Bowin, C., and Segawa, J., 1972. An extinct spreading center in the Philippine Sea. Nature, 240:453-455.

Boyce, R. E., 1976. Definition and laboratory techniques of compressional sound velocity parameters and wet water content, wetbulk density, and porosity parameters by gravimetric and gammaray attenuation techniques. In Schlanger, S. O., Jackson, E. D., et al., Init. Repts. DSDP, 33: Washington (U.S. Govt. Printing Office), 931-958.

Dengler, A. T., Doyle, P. S., and Riedel, W. R., 1975. Ichthyoliths in some samples from the Philippine Sea, Deep Sea Drilling Project Leg 31. In Karig, D. E., Ingle, J. C., Jr., et al., Init. Repts. DSDP, 31: Washington (U.S. Govt. Printing Office), 821-833.

Donnelly, T. W., Francheteau J., Bryan, W., Robinson, P., Flower, M., Salisbury, M., et al., in press. Init. Repts. DSDP, 51, 52, 53: Washington (U.S. Govt. Printing Office).

Doyle, P. S., Kennedy, G. G., and Riedel, W. R., 1974. Stratigraphy. In Davies, T. A., Luyendyk, B. P., et al., Init. Repts. DSDP, 26: Washington, (U.S. Govt. Printing Office), 825-905.

Ellis, C. H., 1975. Calcareous nannofossil biostratigraphy, Leg 31 Deep Sea Drilling Project. In Karig, D. E., Ingle, J. C., Jr., et al., Init. Repts. DSDP, 31: Washington (U.S. Govt. Printing Office), 655-676.

Foster, J., 1972. Paleomagnetism of deep sea sediments [Ph.D. thesis]. Columbia University, New York, New York.

Hilde, T. W. C., Uyeda, S., and Kroenke, L., 1976. Evolution of the Western Pacific and its margin. Tectonophysics, 38:145-165.

Karig, D. E., 1974. Evolution of arc systems in the Western Pacific. Ann. Rev. Earth Planet. Sci., 2:51-75.

1975. Basin genesis in the Philippine Sea. In Karig, D. E., Ingle, J. C., Jr., et al., Init. Repts. DSDP, 31: Washington (U.S. Govt. Printing Office), 857-879.

Karig, D. E., Ingle, J. C., Jr., et al., 1975. Init. Repts. DSDP, 31: Washington (U.S. Govt. Printing Office).

Klein, G. deV., Kobayashi, K., et al., in press. Init Repts. DSDP, 58: Washington (U.S. Govt. Printing Office).

Louden, K. E., 1976. Magnetic anomalies in the West Philippine Basin. In Sutton, G. H., Manghnani, M. H., Moberly, R. (Eds.), The Geophysics of the Pacific Ocean Basin and Its Margin, Geophys. Monogr. Ser. (Vol. 19): Washington (Am. Geophys. Union), 253-267.

1977. Paleomagnetism of DSDP sediments, phase shifting of magnetic anomalies, and rotations of the West Philippine Basin. J. Geophys. Res., 82:2989-3002.

Mrozowski, C. L., and Hayes, D. E., 1979. The evolution of the Parece Vela Basin, Eastern Philippine Sea. Earth Planet. Sci. Lett., 46:49-67.

Müller, C. L., 1970. Nannoplankton aus dem Mittel-Oligozän von Norddeutschland und Belgien. Neues Jahrb. Geol. Palaeontol. Abh., 135:82-101. 
Murauchi, S., Den, N., Asano, S., et al., 1968. Crustal structure of the Philippine Sea. J. Geophys. Res., 73:3143-3171.

Sclater, J. G., Karig, D., Lawver, L. A., et al., 1976. Heat flow, depth, and crustal thickness of the marginal basins of the South Philippine Sea. J. Geophys. Res., 81:309-318.

Seekins, L. C., and Teng, T. L., 1977. Lateral variations in the structure of the Philippine Sea Plate. J. Geophys. Res., 82:317-324.

Tomoda, Y., Kobayashi, K., Segawa, J., et al., 1975. Linear magnetic anomalies in the Shikoku Basin. J. Geomagnet. Geoelec., 28:47-56.
Ujiie, H., 1975. Planktonic foraminiferal biostratigraphy in the Western Philippine Sea, Leg 31 of the Deep Sea Drilling Project. In Karig, D. E., Ingle, J. C., Jr., et al., Init. Repts. DSDP, 31: Washington (U.S. Govt. Printing Office), 677-691.

Watanabe, T., Langseth, M. G., Anderson, R. N., 1977. Heat flow in back-arc basins of the Western Pacific. In Talwani, M., and Pitman, W. C., III (Eds.), Island Arcs, Deep Sea Trenches, and Back-Arc Basins: Washington (Am. Geophys. Union), pp. 137161.

Watts, A. B., Weissel, J. K., Larson, R. L., 1977. Seafloor spreading in basins of the Western Pacific. Tectonophysics, 37:167-181. 


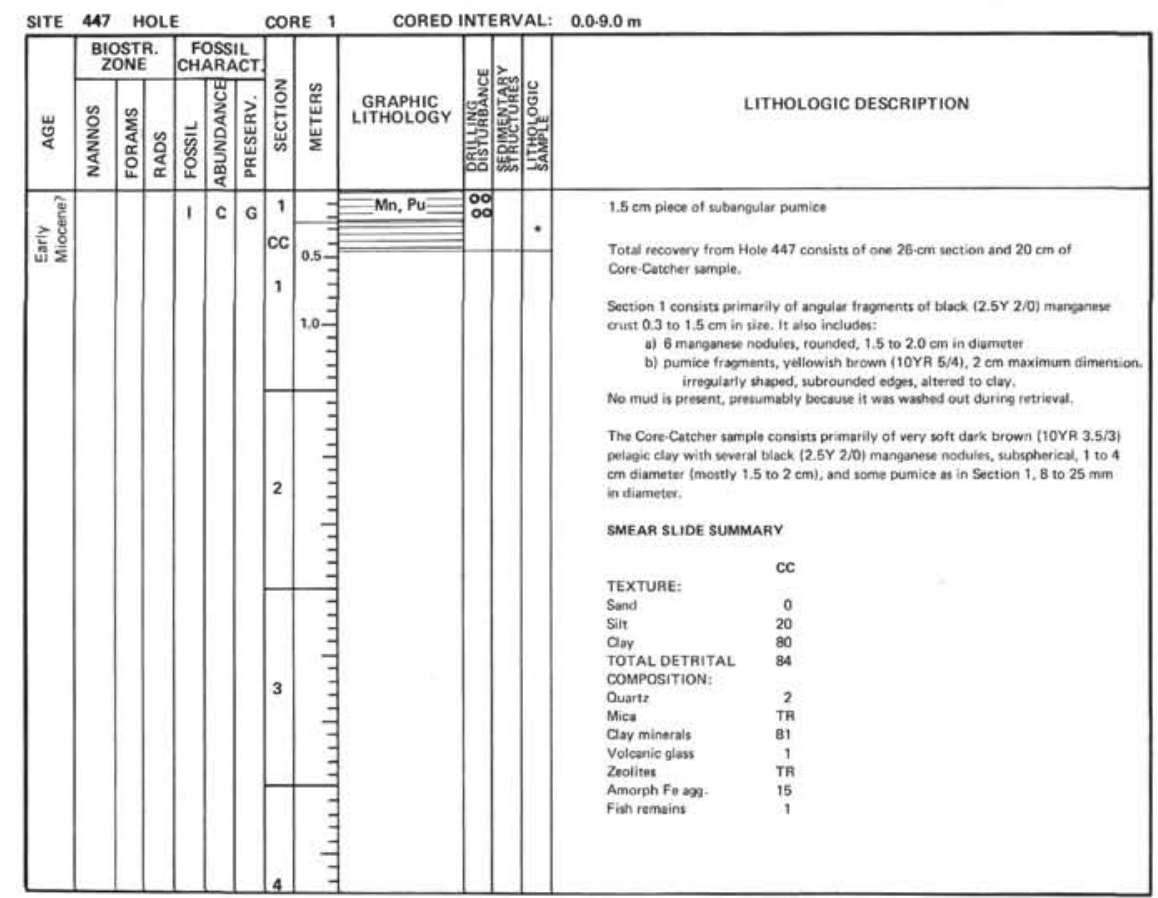

Information on core description sheets, for ALL sites, represents field notes taken aboard ship under time pressure. Some of this information has been refined in accord with postcruise findings, but production schedules prohibit definitive correlation of these sheets with subsequent findings. Thus the reader should be alerted to the occasional ambiguity or discrepancy. 

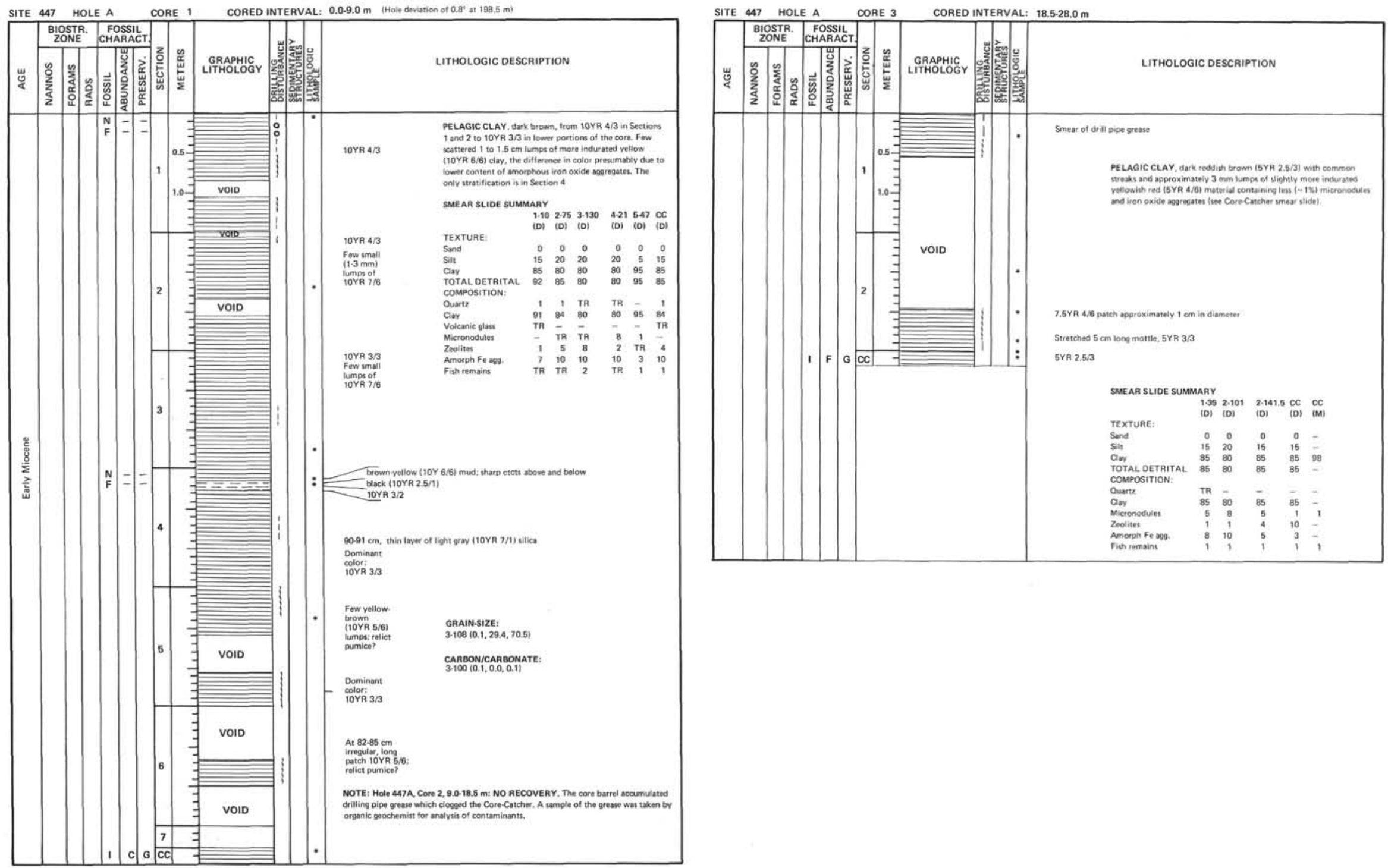


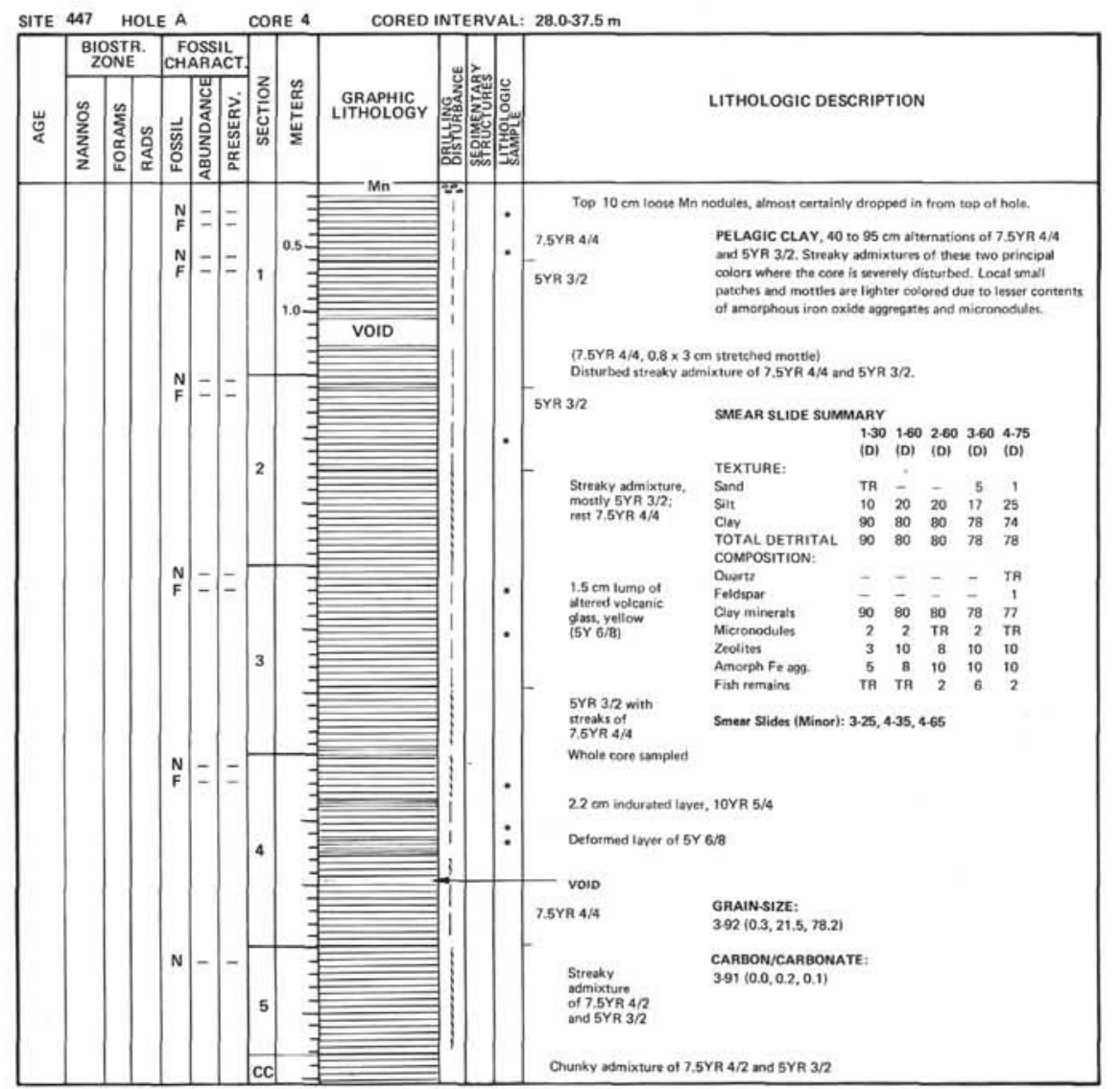

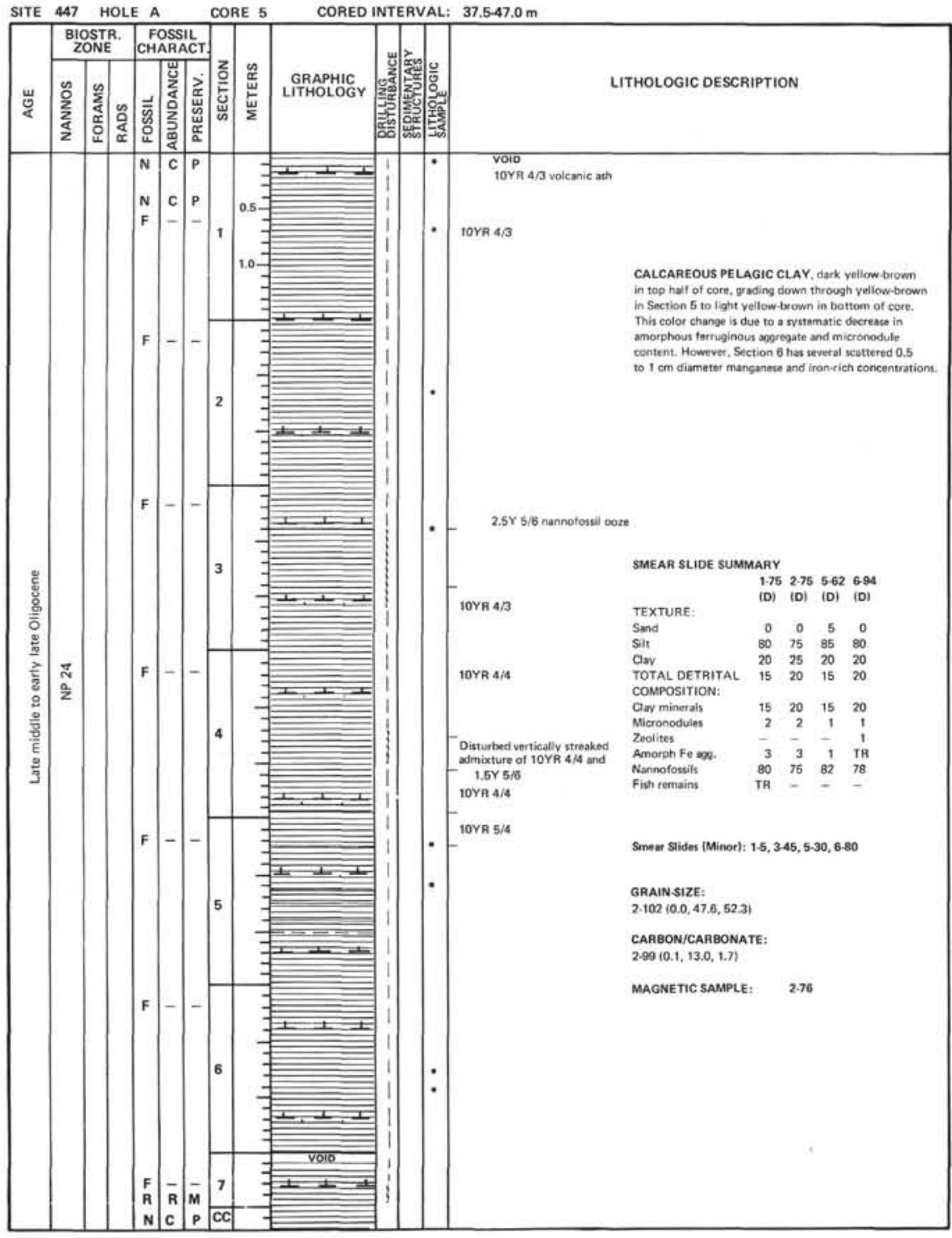




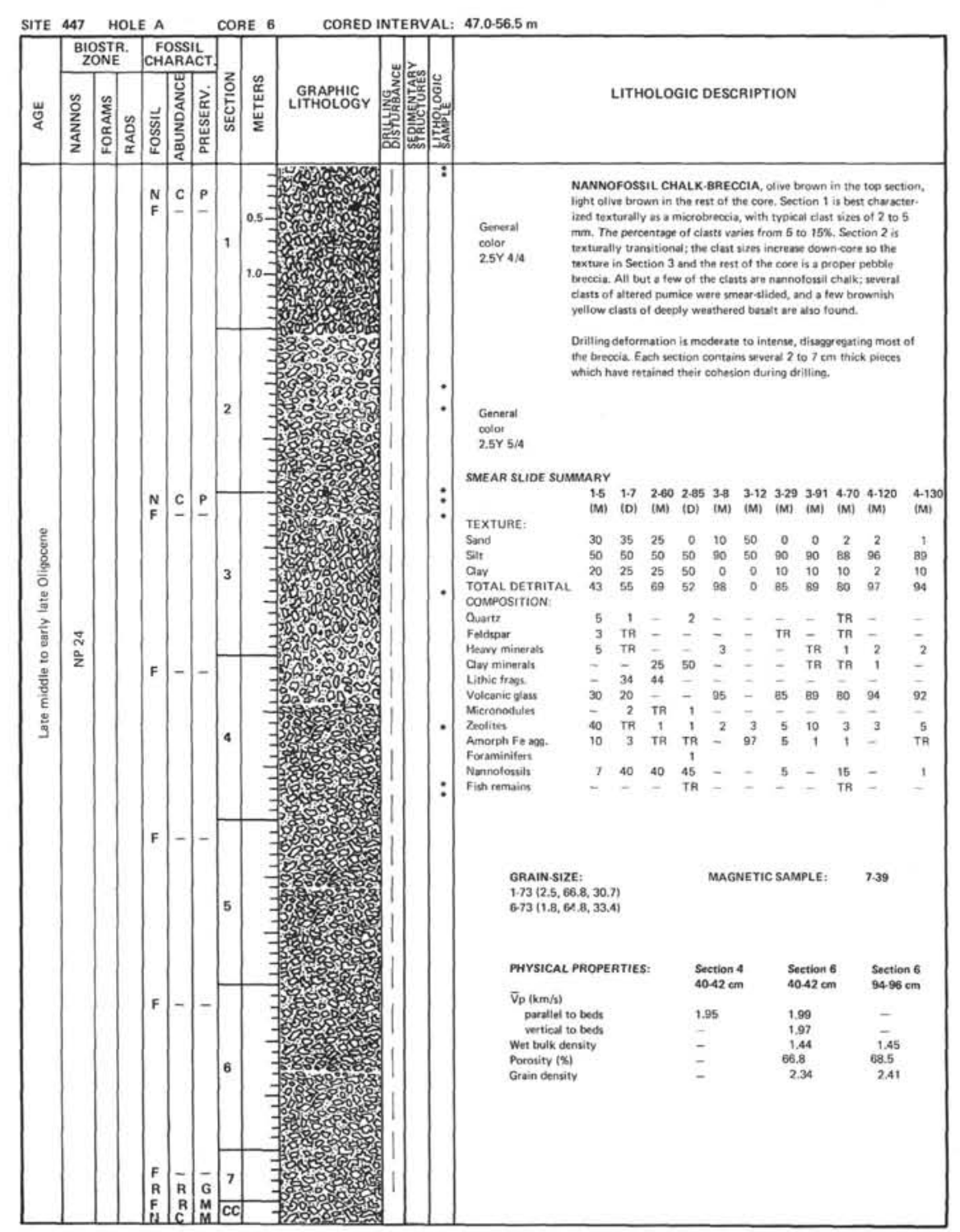

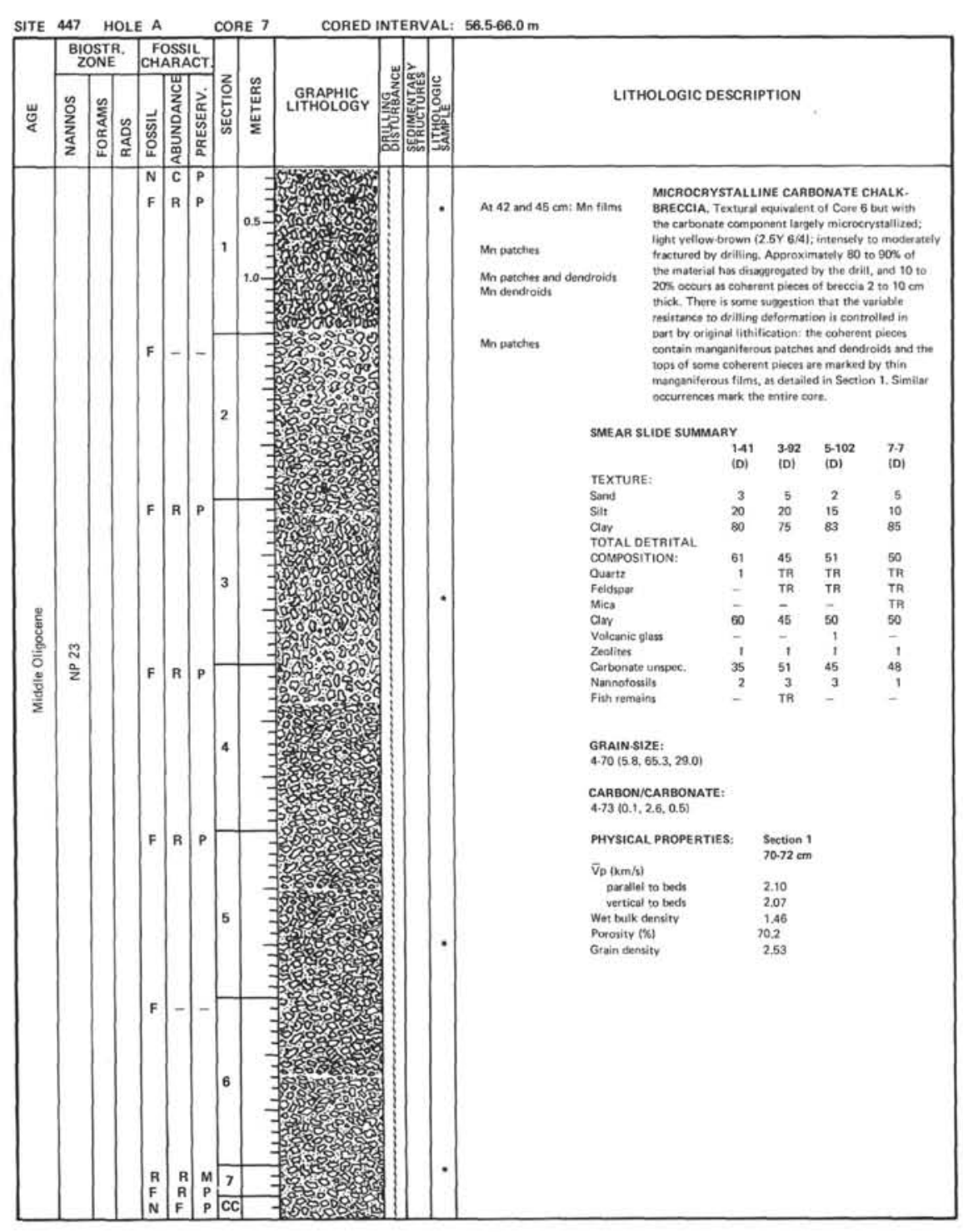




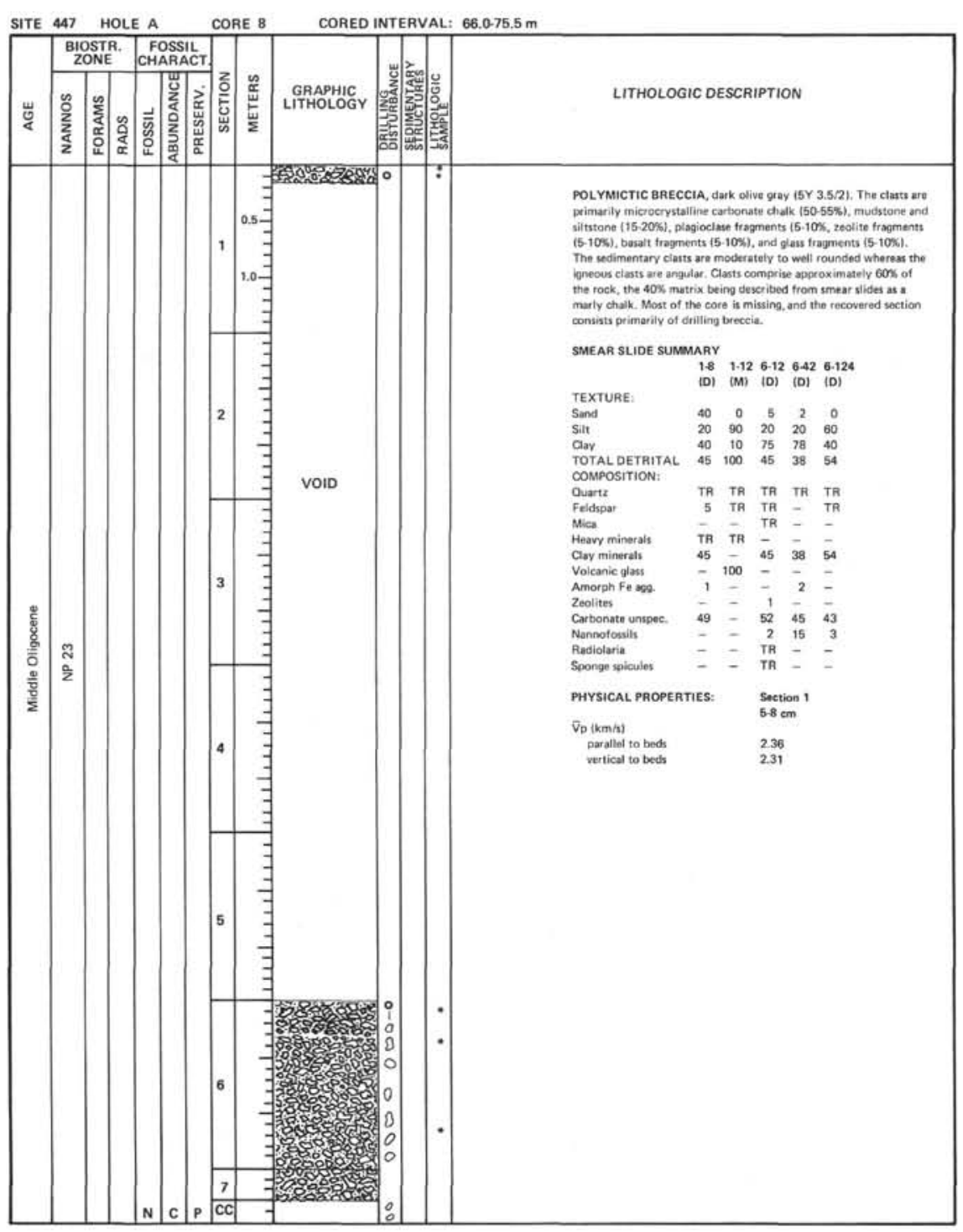

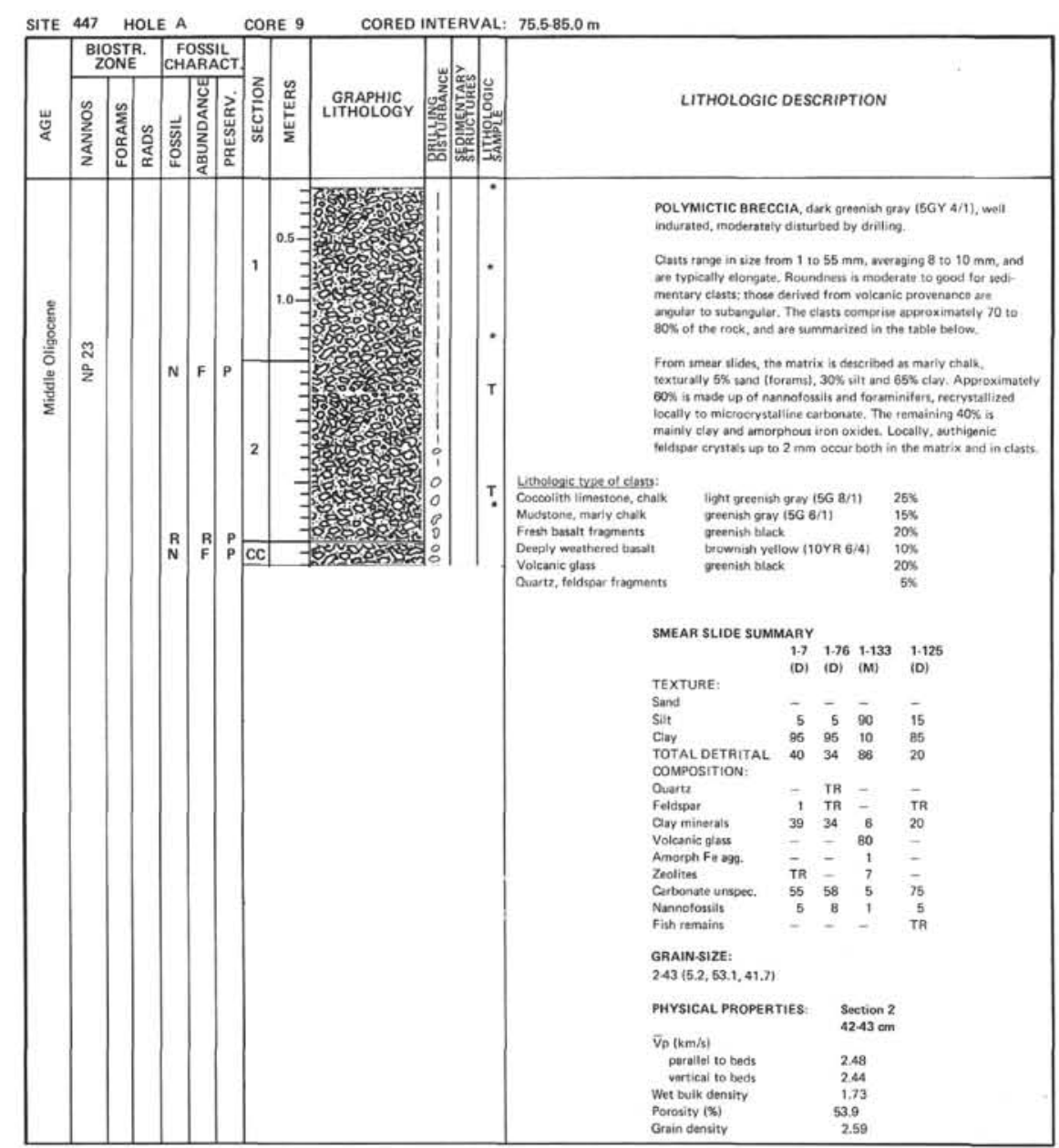




\begin{tabular}{|l|l|l|l|l|l|l|l|l|}
\hline SITE 447 & HOLE A & & \\
\hline
\end{tabular}

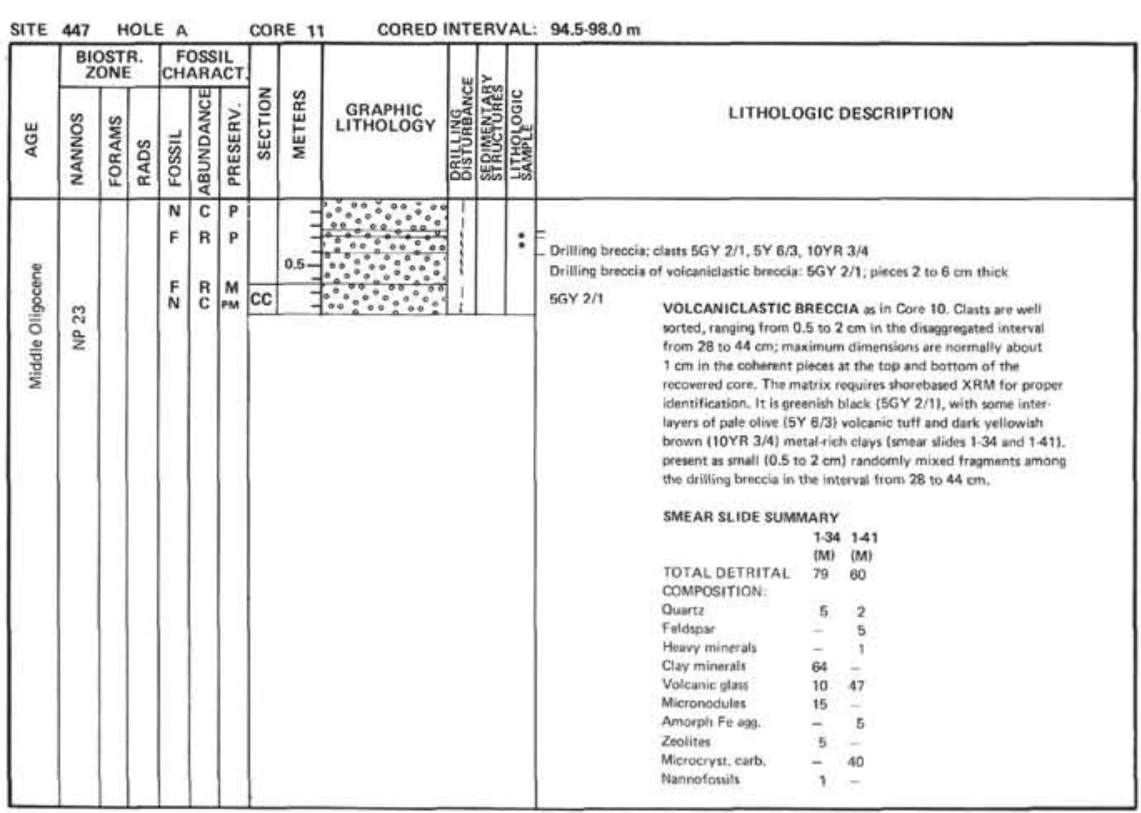




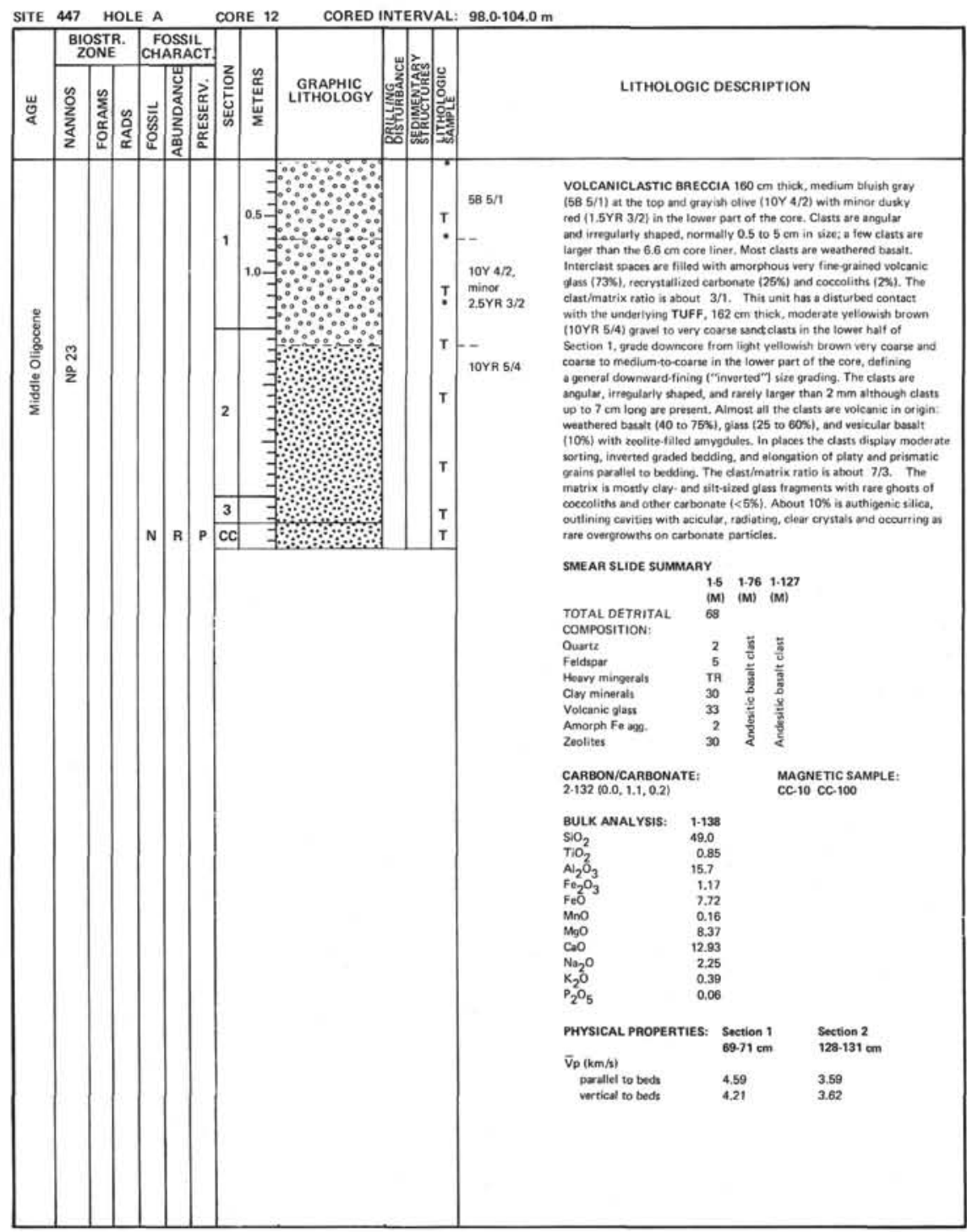

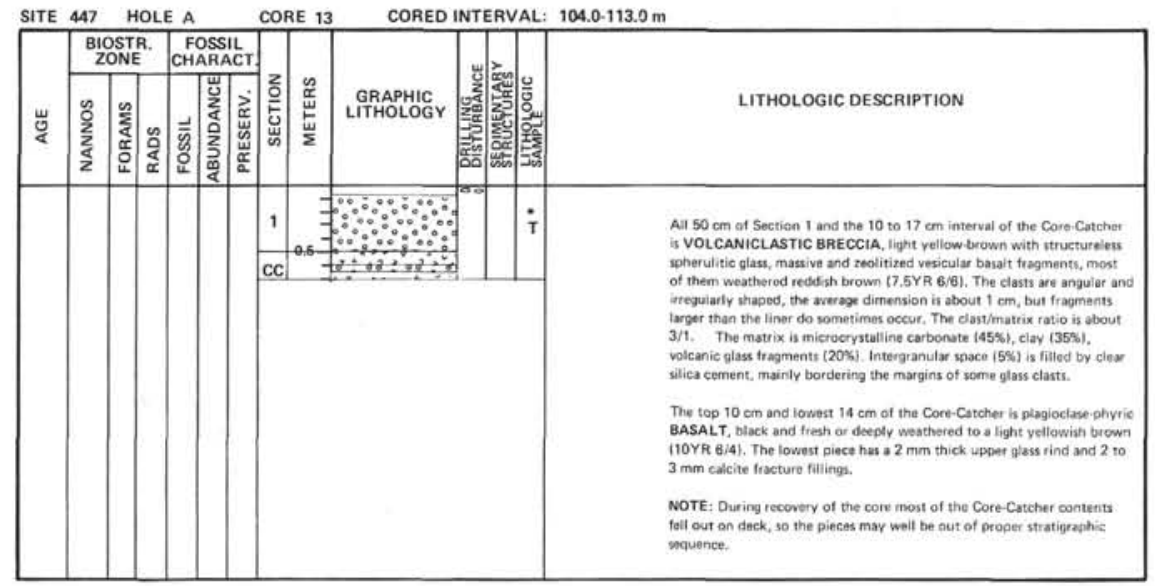



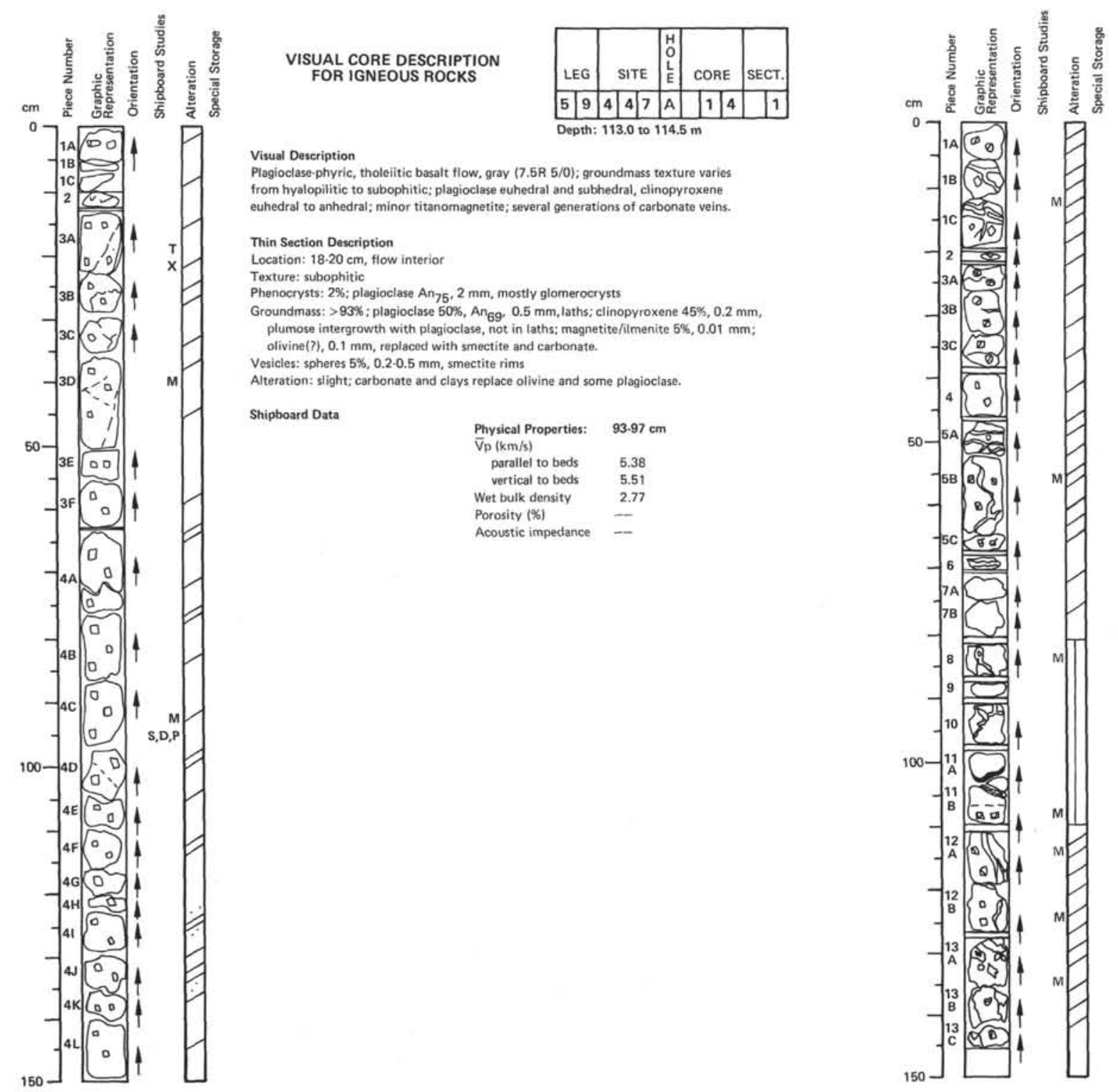 VISUAL CORE DESCRIPTION
FOR IGNEOUS ROCKS

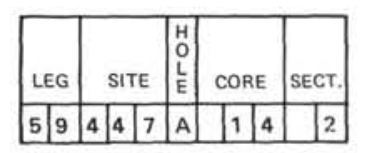

Visual Description

列 athered. Glassy chilied margin, $80.103 \mathrm{~cm}$. Mainly holocrystaline, ine-grained, $(1.0-1.5 \mathrm{~mm})$ of plagioclase and rare olivine (?). Numerous, $1 \cdot 10 \mathrm{~mm}$ wide dikes of same composition, along contacts of which the host rock is slightly altered. 

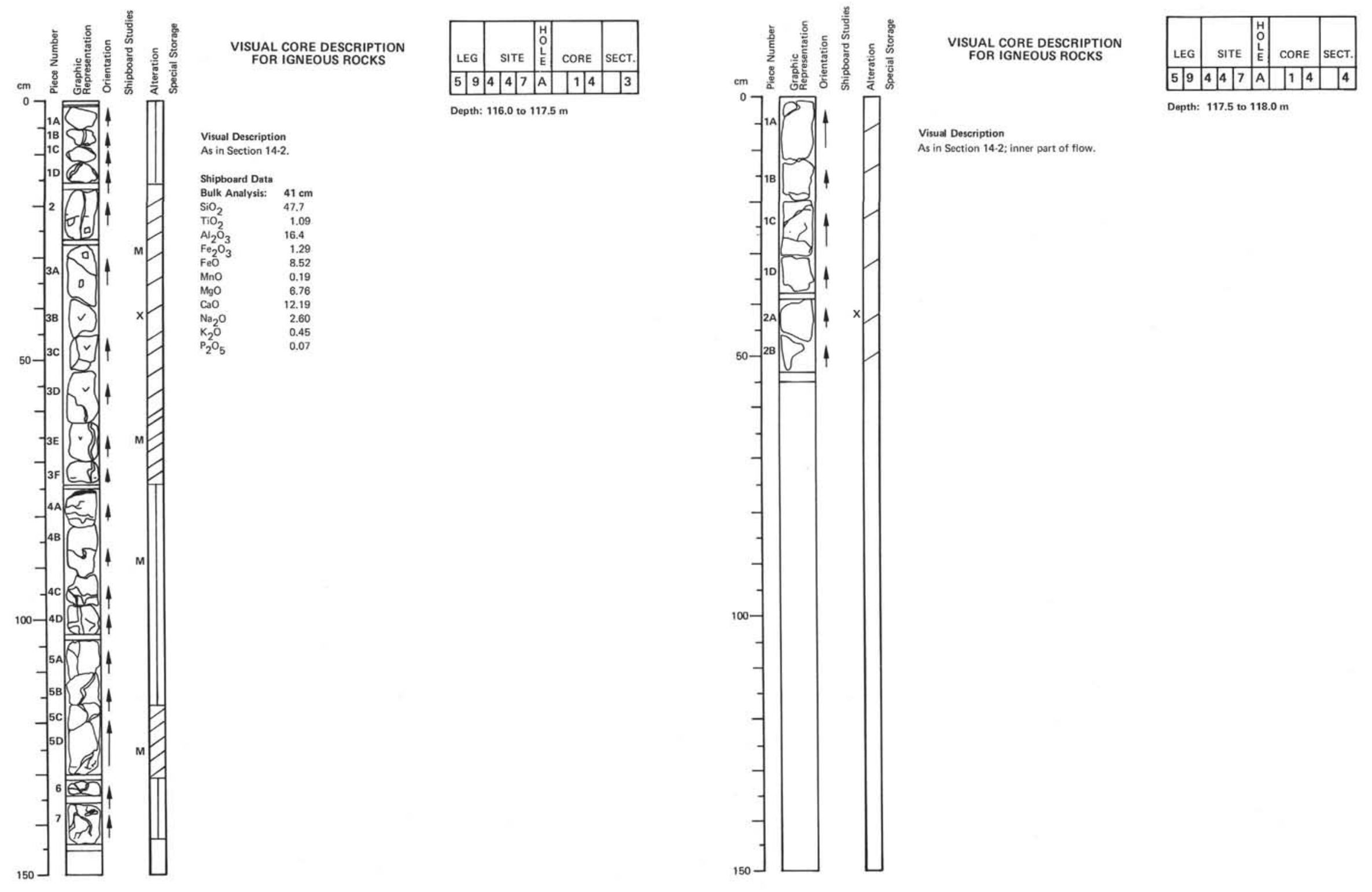


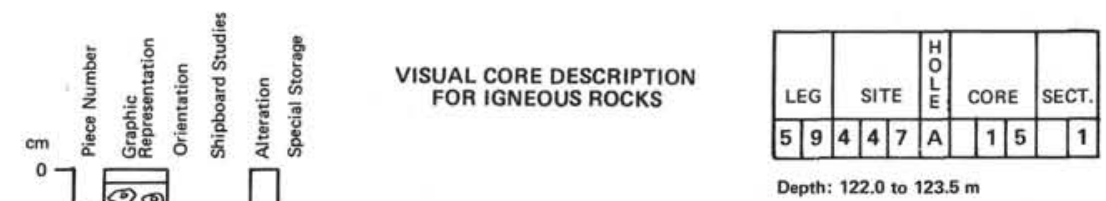

0-100 cm: as in Sections 14-3, 14-4; glassy base.

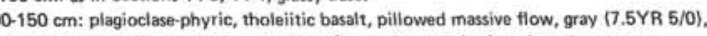
(a)

\section{Thin Section Description}

Location: $26.29 \mathrm{~cm}$, flow interior

Texture: subophitic

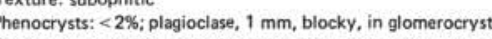

plagioclase laths; olivine $<3 \%, 0.1 \mathrm{~mm}$, replaced with clays

Vesicles: $3 \%, 0.1 \mathrm{~mm}$, with present

Alteration: $-5 \%$ of rock; carbonate (rare) and clays replace olivine and clinopyroxene.

Hematite present in olivine and magnetite.

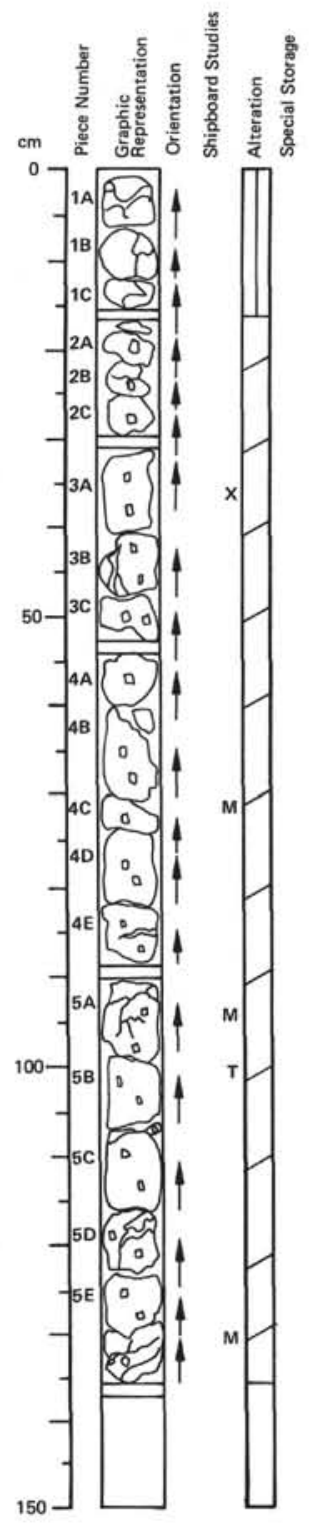

VISUAL CORE DESCRIPTION FOR IGNEOUS ROCKS

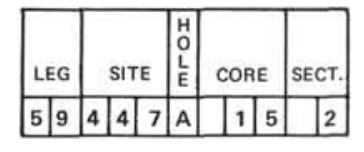

Visual Description

Plagioclase-phyric, tholefitic basalt, pillowed massive flow as in Section 15-1.

Thin Section Description

$98.100 \mathrm{~cm}$, flow interior

(ure: subophitic

Groundmass: > $97 \%$; plagioclase $50 \%, \mathrm{An}_{78}, 1.0 \mathrm{~mm}$, elongate laths; clinopyroxene $45 \%$;

magnetite and ilmenite $<5 \%$

filled with smectite and red cubes (2hematite alteration of pyrite

10\%, carbonate replacing clinopyroxene and some plagioclase; clays replacing

Shipboard Data

Bulk Analysis: $35 \mathrm{~cm} \quad$ Physical Properties: $126.129 \mathrm{~cm}$

$\mathrm{SiO}_{2}$

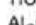

$\mathrm{Al}_{2} \mathrm{O}_{3} \quad 16.3$

\begin{tabular}{ll}
$\mathrm{FeO}_{2} \mathrm{O}_{3}$ & 1.27 \\
\hline & 8.41
\end{tabular}

$\begin{array}{ll}\mathrm{MnO} & 0.19 \\ \mathrm{MgO} & 6.71\end{array}$

$\begin{array}{rr}\mathrm{MgO} & 6.71 \\ \mathrm{CaO} & 11.51\end{array}$

$\begin{array}{ll}\mathrm{Na}_{2} \mathrm{O} & 2.75 \\ \mathrm{~K}_{2} \mathrm{O} & 0.50 \\ \mathrm{P}_{2} \mathrm{O}_{2} & 0.08\end{array}$

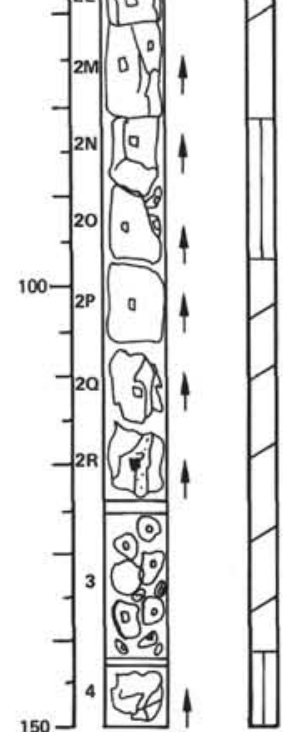



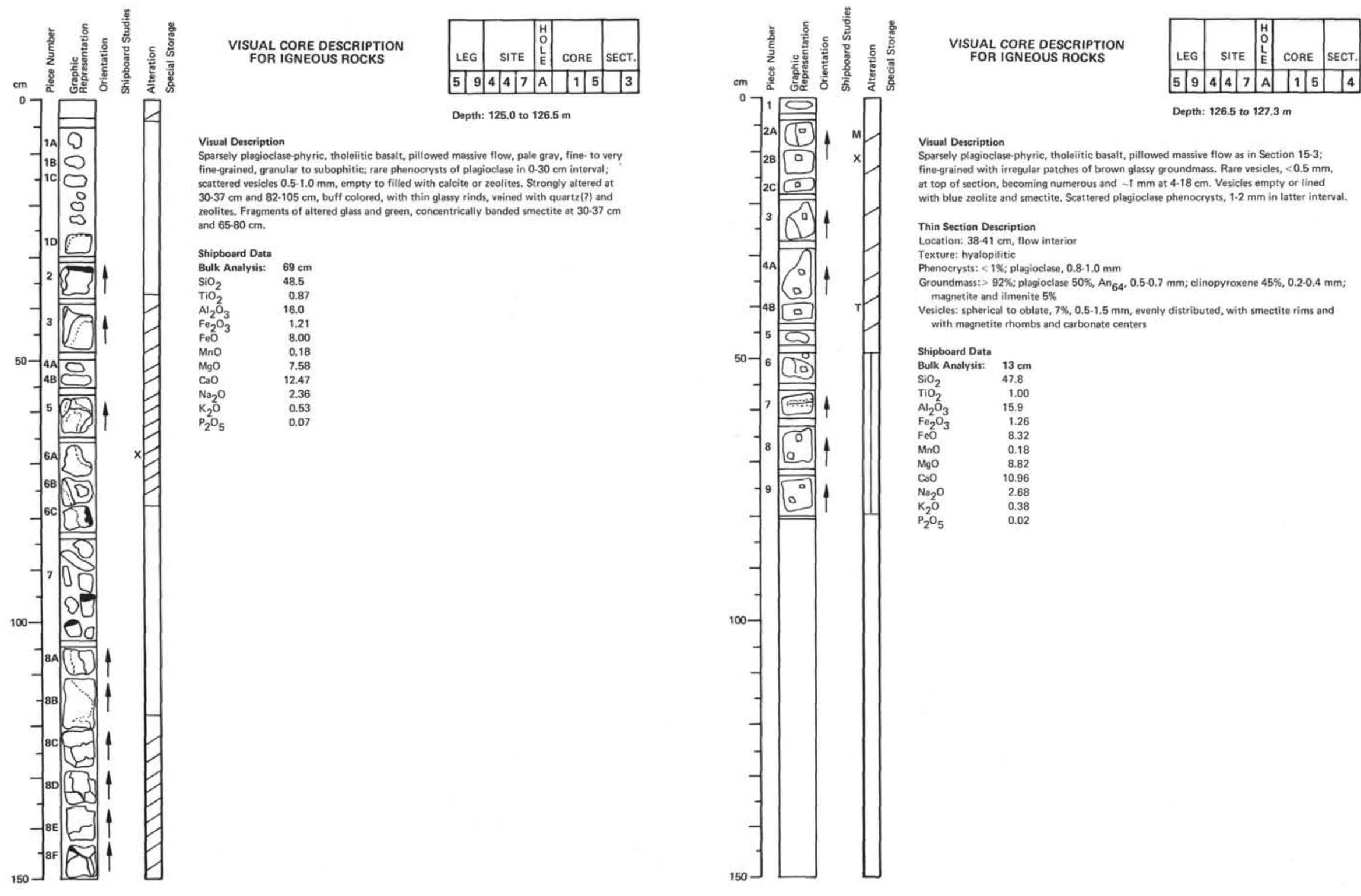

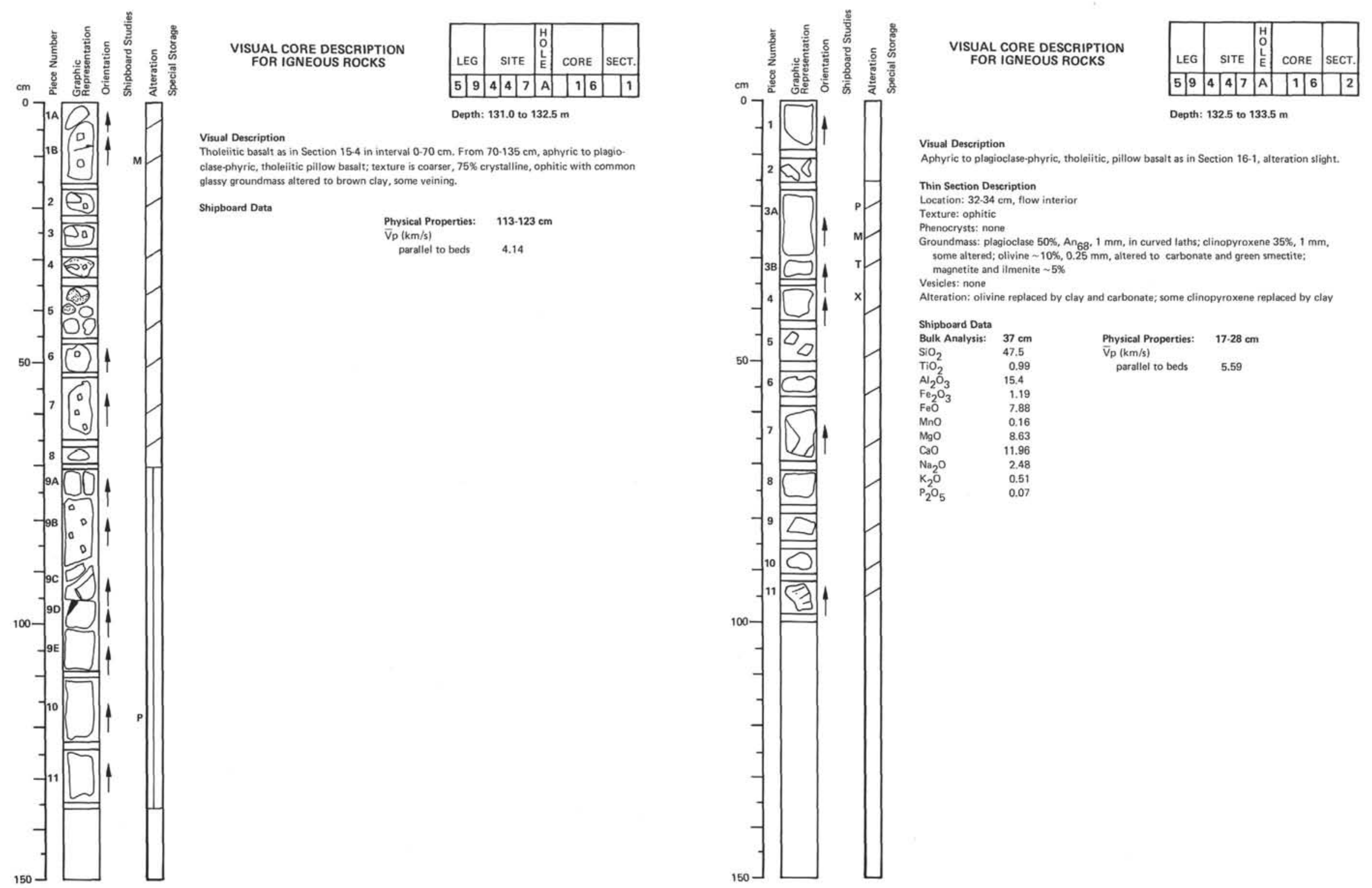

Visual Description
Tholelitic basalt as in Section 15.4 in interval 0-70 cm. From $70.135 \mathrm{~cm}$, aphyric to plagioTholeitic basalt as in Section 15.4 in interval $0.70 \mathrm{~cm}$. From $70.135 \mathrm{~cm}$, aphyric to plagio-
clase-phyric, tholeitic pillow basalt; texture is coarser, $75 \%$ crystalline, ophitic with common clase-phyric, tholeiltic pillow basalt; texture is coarser, $75 x$ a
glassy groundmass altered to brown clay, some veining.

Shipboard Data

$$
\begin{array}{ll}
\begin{array}{c}
\text { Physical Properties: } \\
\text { V } p \text { (km/s) } \\
\text { parallel to beds }
\end{array} & \quad 113.123 \mathrm{~cm} \\
& 4.14
\end{array}
$$

Visual Description

Aphyric to plagioclase-phyric, tholeiitic, pillow basalt as in Section 16-1, alteration slight.

Thin Section Description

Location: $32 \cdot 34 \mathrm{~cm}$, flow interior

Texture: ophitic
Phenocrysts: none

Groundmass: plagioclase 50\%, An $1 \mathrm{~mm}$, in curved laths: clinopyroxene $35 \%, 1 \mathrm{~mm}$ some altered; olivine $\sim 10 \%, 0.25 \mathrm{~mm}$, altered to carbonate and green smectite; magnetite and ilmenite $\sim 5 \%$ Aesicles. none

$\begin{array}{lll}\text { Shipboard Data } & & \\ \text { Bulk Analysis: } 37 \mathrm{~cm} & \text { Physical Properties: } & 17.28 \mathrm{~cm}\end{array}$

$\begin{array}{lccc}\mathrm{SiO}_{2} & 47.5 & \overline{\mathrm{V}} \mathrm{p}(\mathrm{km} / \mathrm{s}) & \\ \mathrm{TiO}_{2} & 0.99 & \text { parallel to beds } & 5.59\end{array}$

$\mathrm{Al}_{2} \mathrm{O}_{3} \quad 15.4$

$\mathrm{FeO}_{2} \mathrm{O}_{3} \quad 7.88$

$\begin{array}{ll}\mathrm{MnO} & 0.16 \\ \mathrm{MgO} & 8.63\end{array}$

$\mathrm{CaO} \quad 11.96$

$\begin{array}{ll}\mathrm{Na}_{2} \mathrm{O} & 2.48 \\ \mathrm{~K}_{2} \mathrm{O} & 0.51 \\ \mathrm{P}_{2} \mathrm{O} & 0.07\end{array}$

0.51 

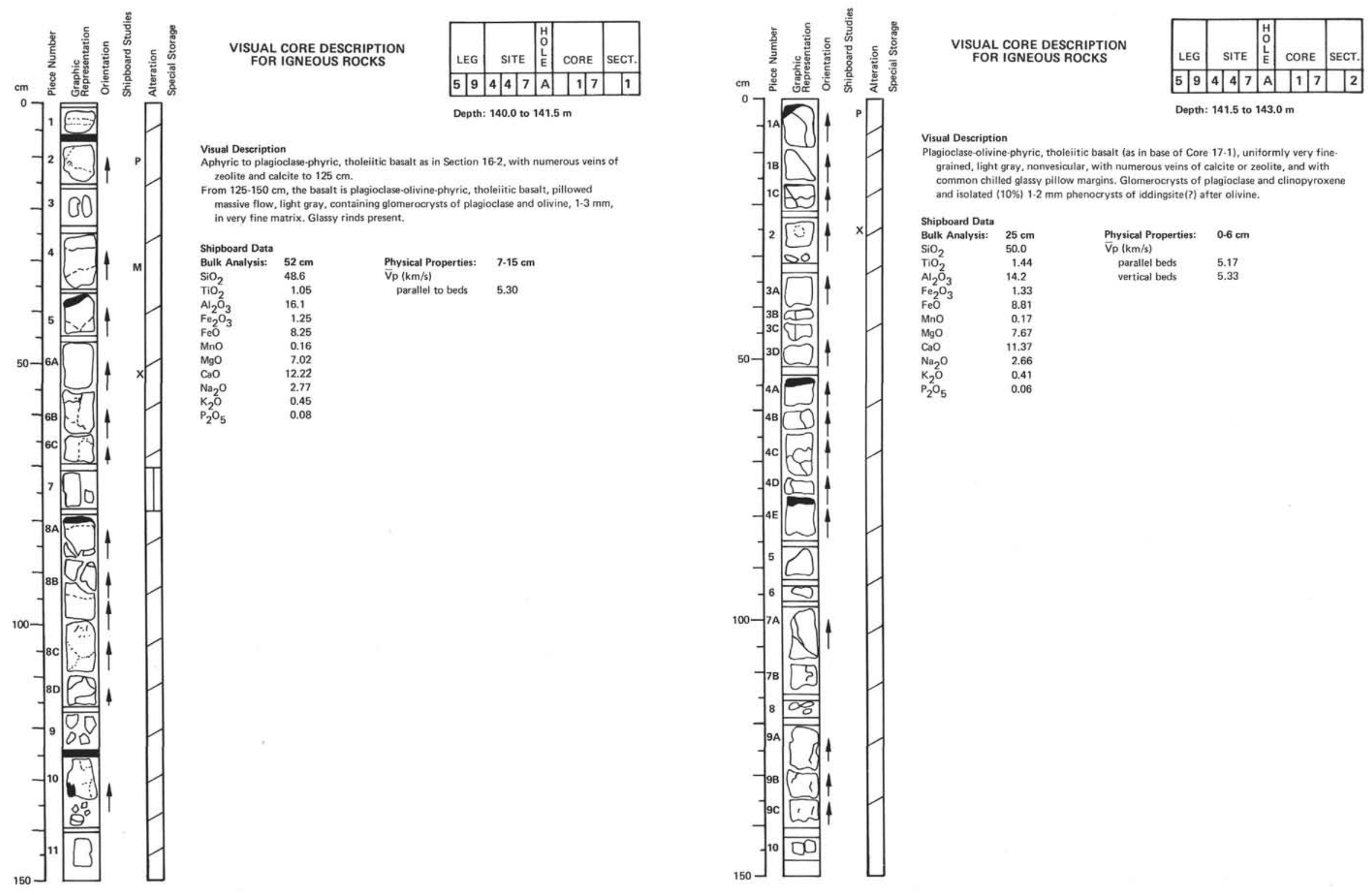


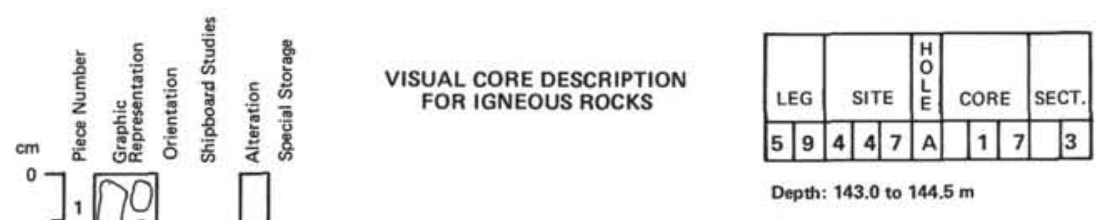

Visual Description
Plagioclase-clinopyroxene-phyric basalt as in Section $17-2$ becoming less porphyritic toWards base of section,
Thin Section Description

Thin Section Description

Lecation: Tob $10 \mathrm{c}$

Phenocrysts: 15\%; plagioclase 60\%, An $80.1 \mathrm{~mm}$, in glomerocrysts with clinopyroxene, and in blocky crystals; clinopyroxene $40 \%, 1 \mathrm{~mm}$

Groundmass: > $84 \%$; plagioclase $10 \%, 0.4 \mathrm{~mm}$, lath microcrysts; olivine $2 \%, 0.1 \mathrm{~mm}$ skeletal microcrysts; plumose intergrowths of very fine plagioclase and clinopyroxene. 80\%; glass 8\%

Vesides: $<1 \%$, spherical, 0.05

\section{Shipboard Data}

$105 \mathrm{~cm}$
50.4
1.42
14.3

Physical Proper

$128.134 \mathrm{~cm}$

$50-$

14.3
1.23
8.13

Paralle

5.3

$\begin{array}{ll}\mathrm{Fe}_{2} \mathrm{O}_{3} & 1.23 \\ \mathrm{FeO} & 8.13\end{array}$

$\begin{array}{lll}\mathrm{MnO} & 0.17 \\ \mathrm{MgO} & 8.08\end{array}$

$\begin{array}{rr}\mathrm{MgO} & 8.08 \\ \mathrm{CaO} & 11.86\end{array}$

$\mathrm{Na}_{2} \mathrm{O} \quad 2.68$

$\begin{array}{ll}\mathrm{K}_{2} \mathrm{O} & 0.57 \\ \mathrm{P}_{2} \mathrm{O}_{5} & 0.10\end{array}$

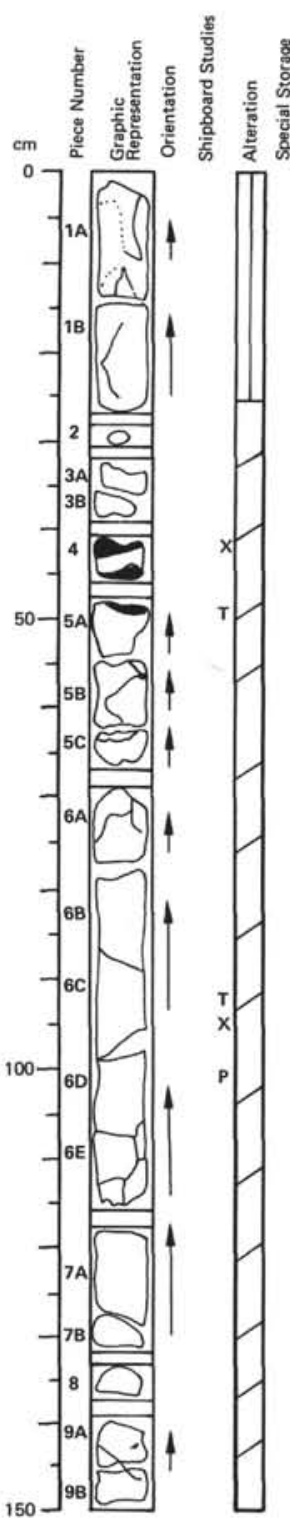
VISUAL CORE DESCRIPTION
FOR IGNEOUS ROCKS

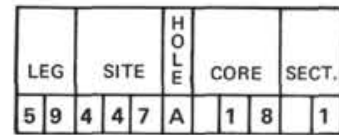

Depth: 149.0 to $150.5 \mathrm{~m}$

\section{Visual Description}

Plagioclase-clinopyroxene-olivine-phyric, tholeiitic basalt (as in Section 17-3); fine-grained crysts holocrystalline, pale gray; scattered phenocrysts of plagioclase, in places glomero. common, $1-2 \mathrm{~mm}$, filled with green smectite and/or zeolite. Occasional glassy rinds.

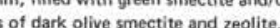

Thin Section Description

Location: $47-49 \mathrm{~cm}$, next to glassy margin

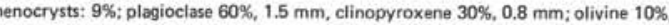
mostly variolitic 85\% (a)

Thin Section Description

Location: $82.94 \mathrm{~cm}$, flow interio

Phenocrysts: 10\%; plagioclase $35 \%, \mathrm{An}_{85}, 1.5 \mathrm{~mm}$, glomerocrysts with clinopyroxene

$0.5 \mathrm{~mm}$ plumose in graphic intergrowths with clinopyroxene 35\%, $0.2 \mathrm{~mm}$; magnetite and ilmenite 5\%; glass 10\%, interstitisi.

Shipboard Dato Physical Properties: $\quad 99-107 \mathrm{~cm}$ parallel to beds $\quad 5.60$ 

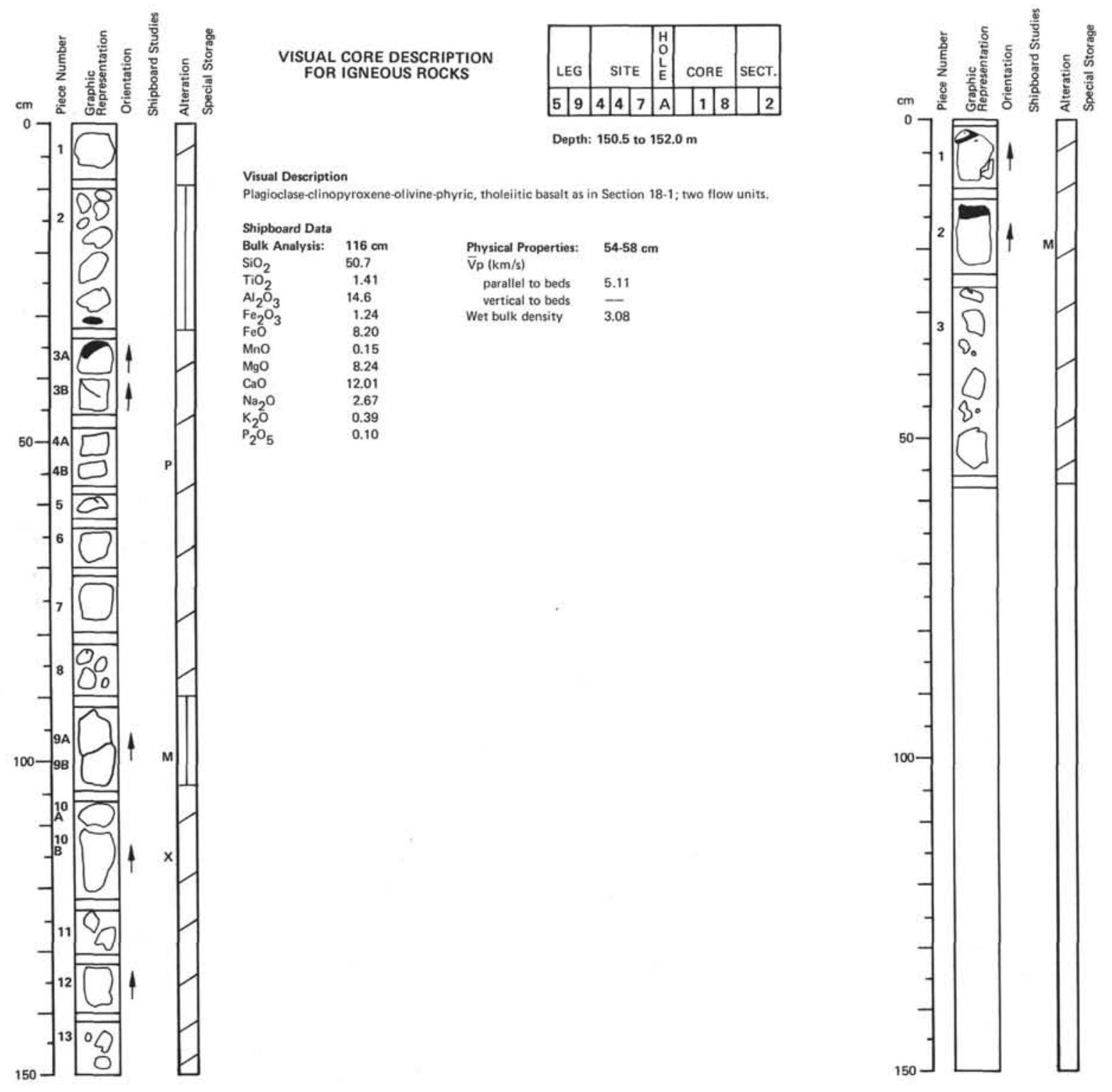
VISUAL CORE DESCRIPTION
FOR IGNEOUS ROCKS

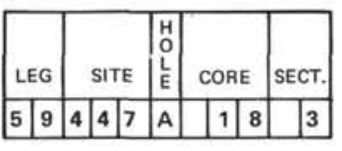

Visual Description
Plagioclase-clinopyroxene-olivine-phyric, tholeitic basalt flow as in Sections 18-1 and 18-2.

Depth: 152.0 to $153.5 \mathrm{~m}$ 

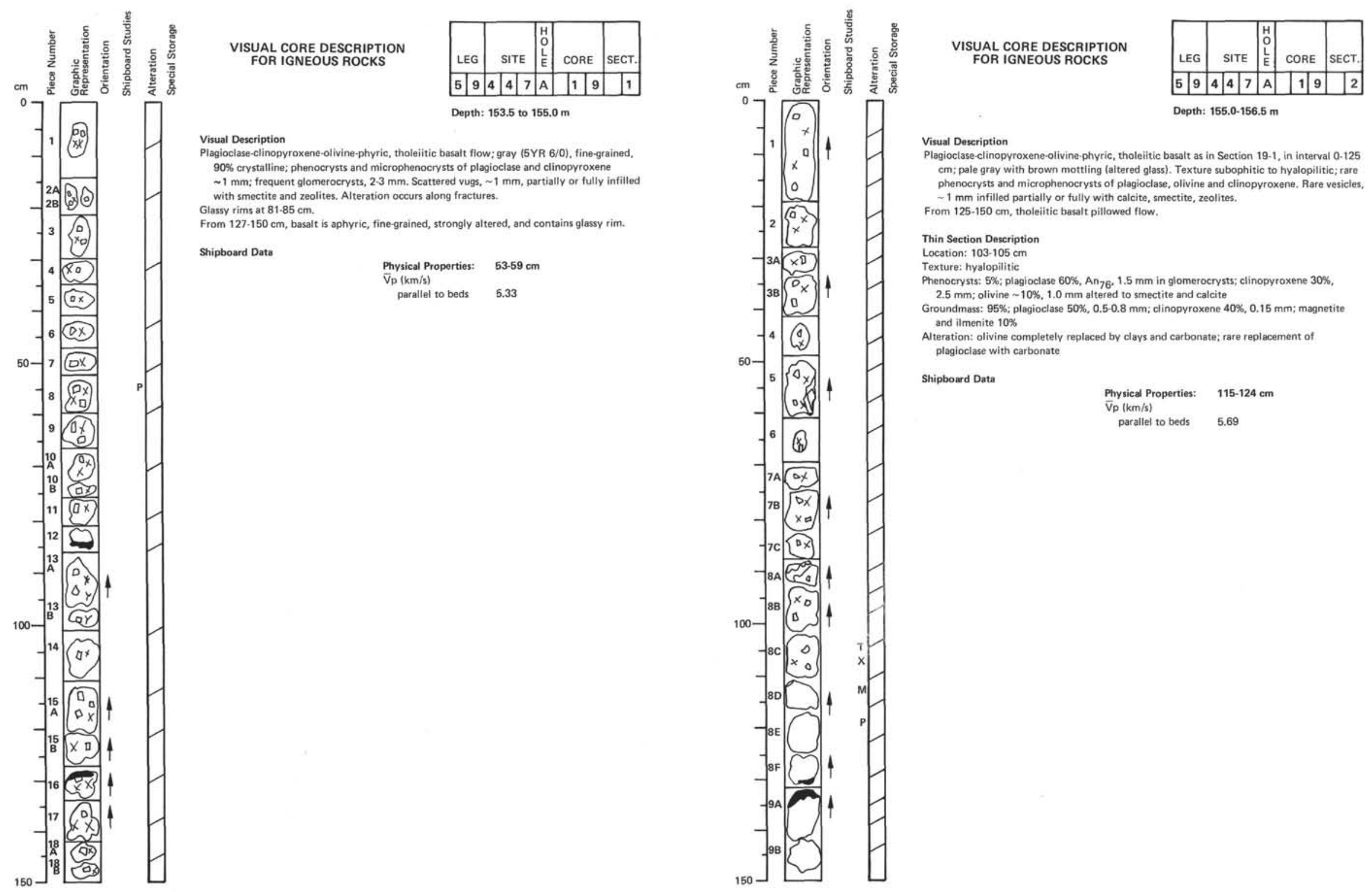

Visual Description

Pagioclase-clinopyroxene-olivine-phyric, tholeititic bassalt as in Section 19-1, in interval 0.125 $\mathrm{cm}$; pale gray with brown mottling (altered glass). Texture subophitic to hyalopilitic; rare $-1 \mathrm{~mm}$ infilled partilly or tully with alcite, smectite, zeolines. From $125.150 \mathrm{~cm}$, tholeitic hassalt pillowed flow.

Thin Section Description Location: $103 \cdot 105 \mathrm{~cm}$

Phenocrysts: 5\%; plagioclase 60\%, An $76,1.5 \mathrm{~mm}$ in glomerocrysts; clinopyroxene $30 \%$, $2.5 \mathrm{~mm}$; olivine $-10 \%, 1.0 \mathrm{~mm}$ altered to smectite and calcite Groundmass: 95\%; plagioclase $50 \%, 0.5-0.8 \mathrm{~mm}$; clinopyroxene $40 \%, 0.15 \mathrm{~mm}$; magnetite

and ilmenite $10 \%$
Alteration: olivine completely replaced by clays and carbonate; rare replacement of Shipboard Data Physical Properties: $\quad 115-124 \mathrm{~cm}$ $\bar{V}_{p}(\mathrm{~km} / \mathrm{s})$ parallet to beds $\quad 5.69$ 

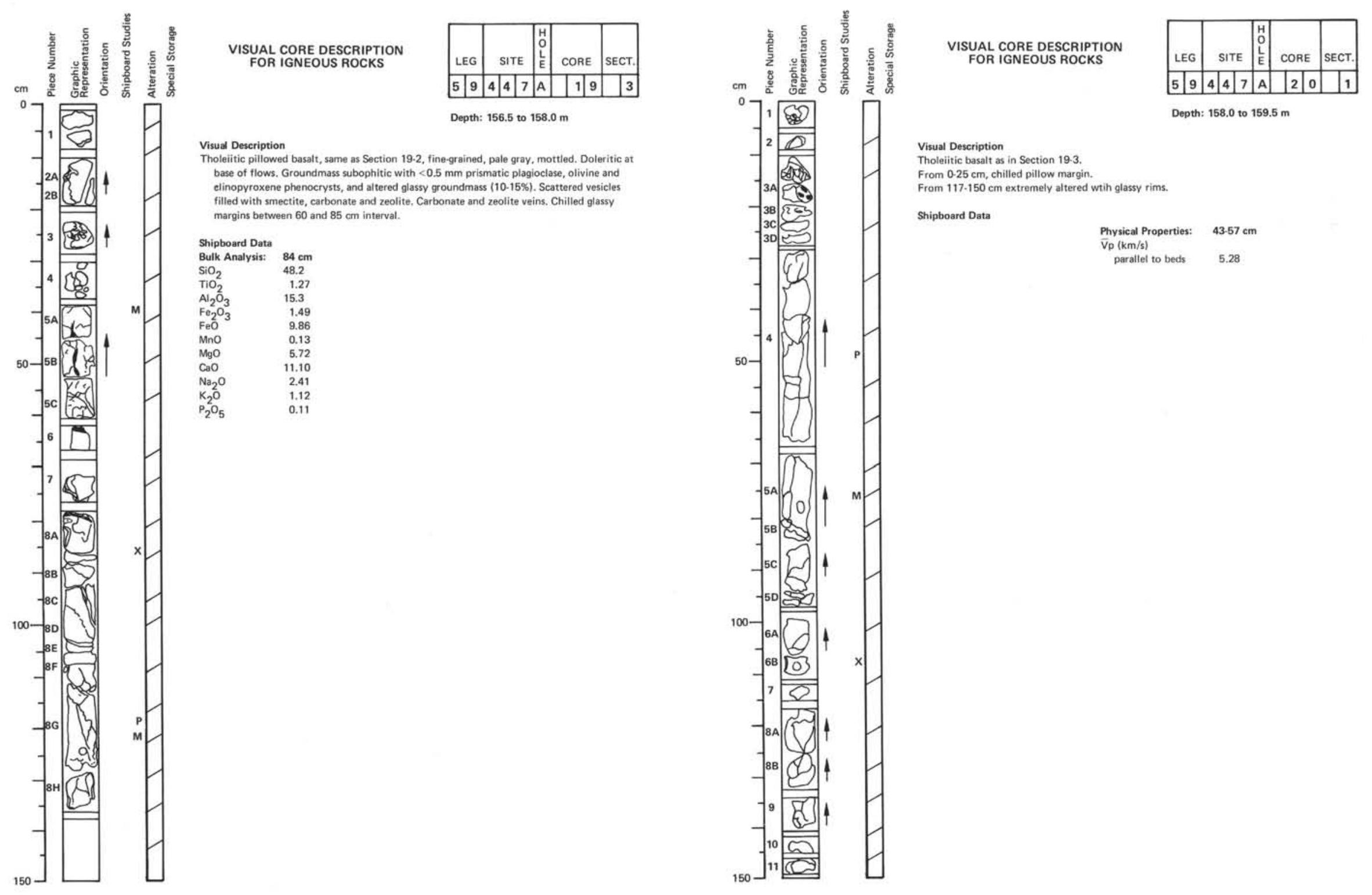

Tholeiitic basalt as in Section 19-3.

From $0.25 \mathrm{~cm}$, chilled pillow margin.
From $117.150 \mathrm{~cm}$ extremely altered wtih glassy rims.

Shipboard Data

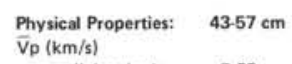

$\mathrm{V}_{p}(\mathrm{~km} / \mathrm{s})$
parallel to beds $\quad 5.28$ 

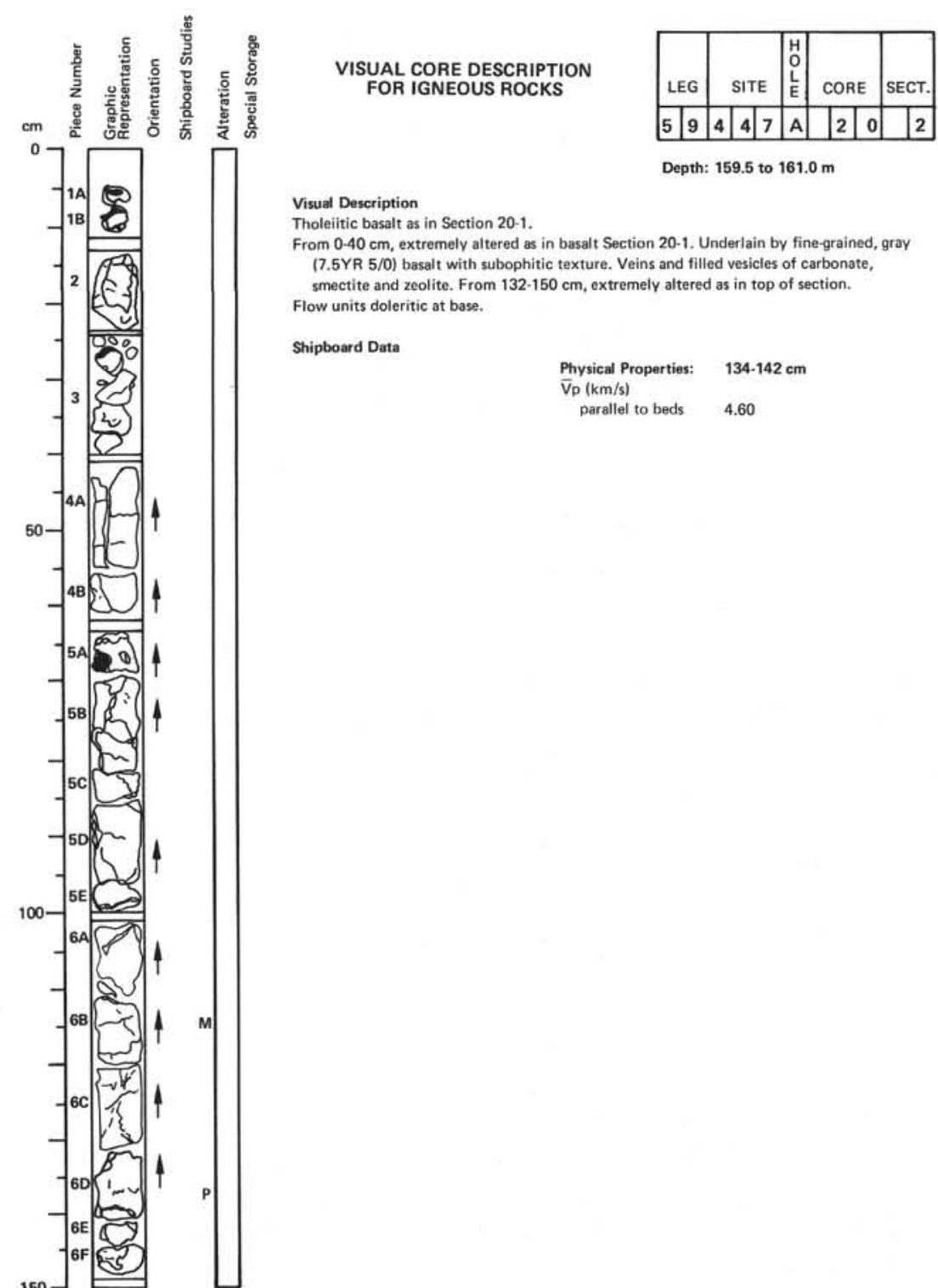

red as in basalt Section 20-1. Underlain by fine-grained, gray From $0.40 \mathrm{~cm}$, extremely altered as in bestic smectite and zeolite. From $132.150 \mathrm{~cm}$, extrems Flow units doleritic at base.

Shipboard Data

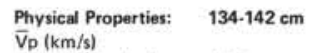

$V_{p}(\mathrm{~km} / \mathrm{s})$ 4.60

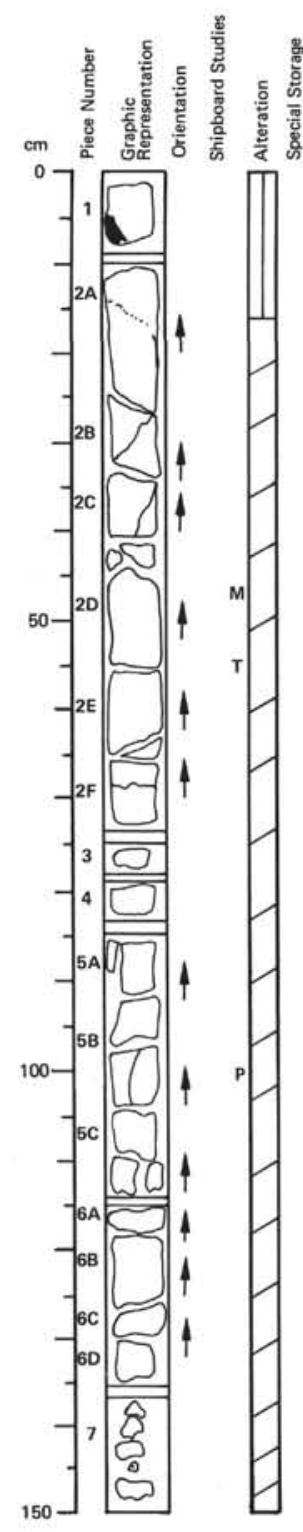

VISUAL CORE DESCRIPTION FOR IGNEOUS ROCKS

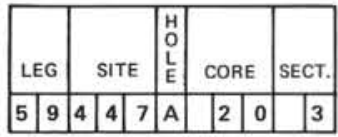

Depth: 161.0 to $1625 \mathrm{~m}$

Visual Descriptio

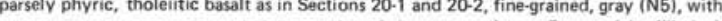

Thin Section Descriptio

How interior

Phenocrysts: $<5 \%$; plagioclase $90 \%, 1.5 \mathrm{~mm}$ in glomerocrysts; olivine, $0.6 \mathrm{~mm}$ as pseudo. morphs or smectite; clinopyroxene, $0.4 \mathrm{~mm}$, rare

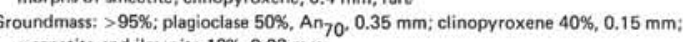

olivine phenocrysts altered to clays and carbonate

Shipboard Data

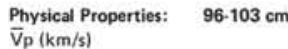

$\bar{V}_{p}(k m / s)$
parallel $96.103 \mathrm{~cm}$ parallel to beds 


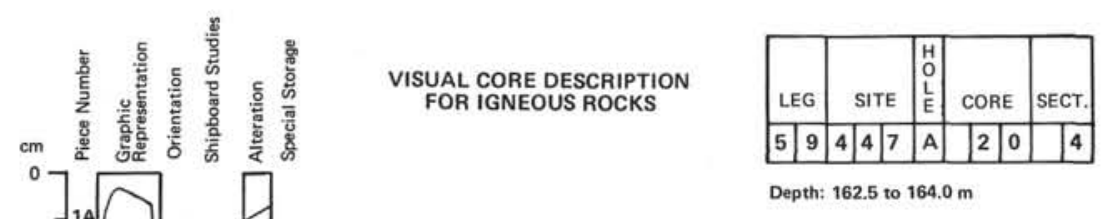

Visual Description

Sparsely phyrie tholeitic baseatt as in Sections 20-1, 20.2, and 20.3

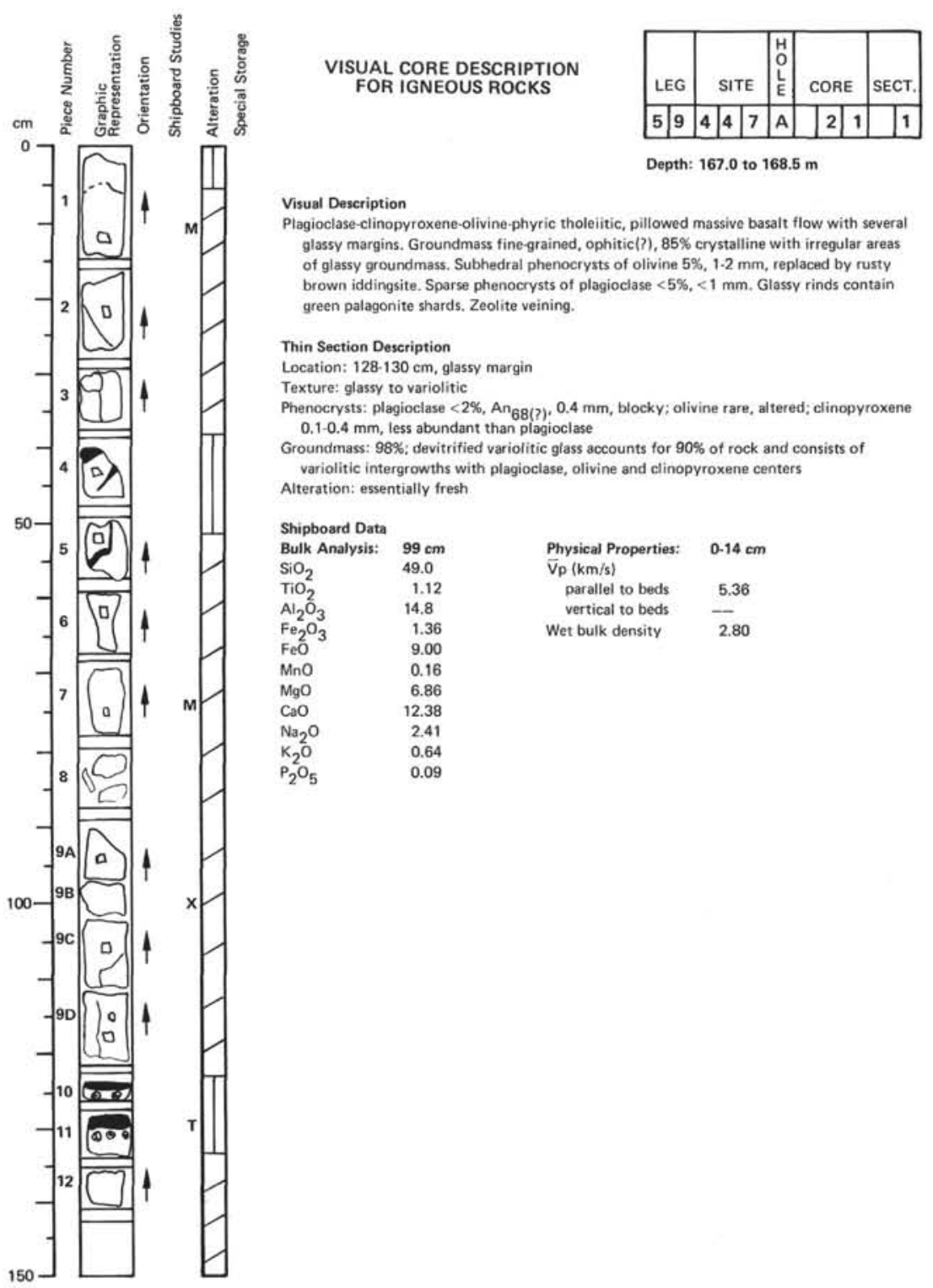



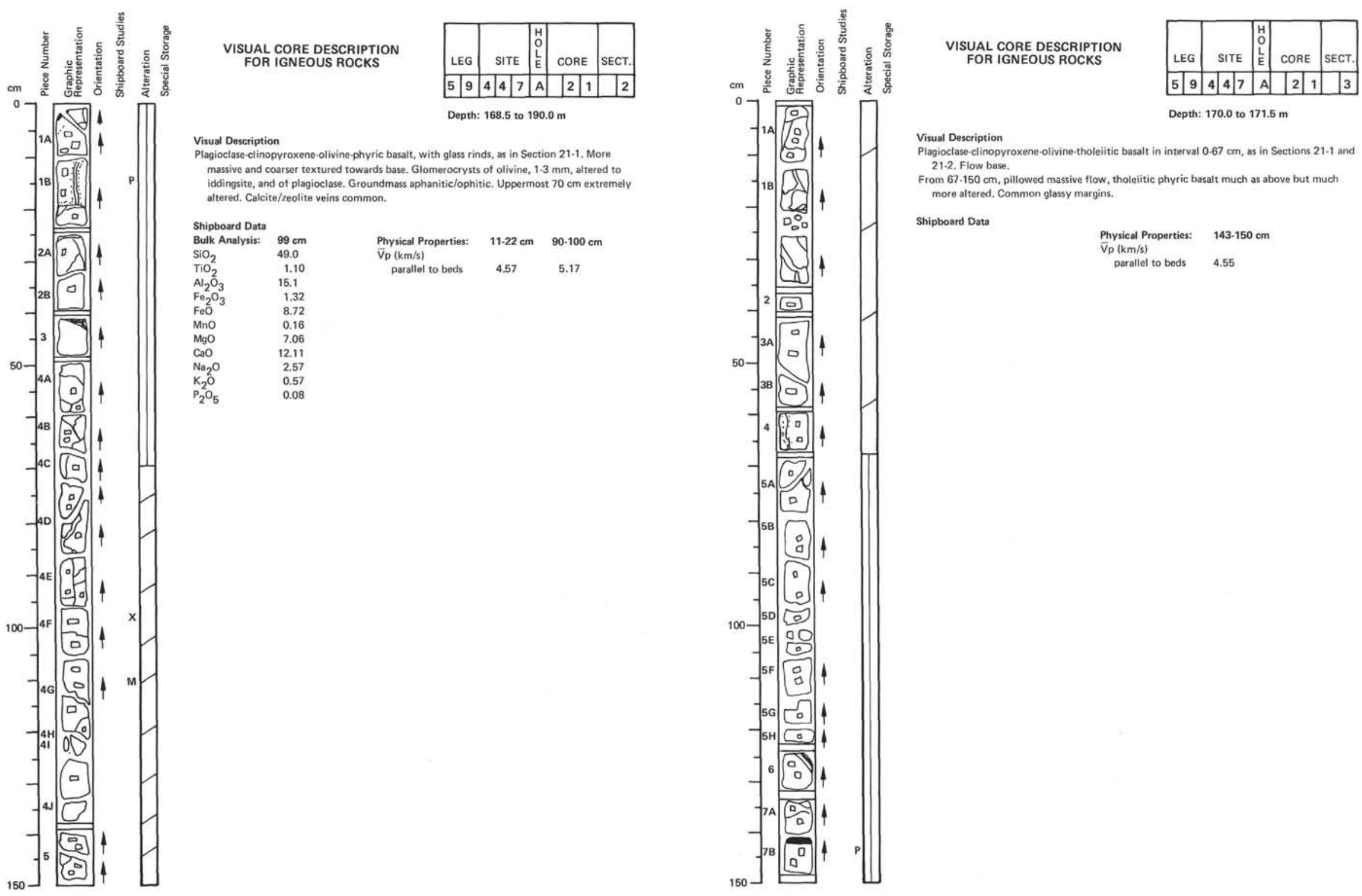

Visual Description

Plagioclase-clinopyroxene-olvine-tholeitic basalt in interval $0-67 \mathrm{~cm}$, as in Sections $21-1$ and 21-2, Flow base.

pillowed massive flow, tholeitic phyric basalt much as above but much d. Common glassy margins.

Shipboard Data

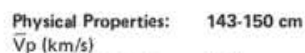

$\overline{\mathrm{V}} \mathrm{p}(\mathrm{km} / \mathrm{s})$

$143.150 \mathrm{~cm}$

parallel to beds $\quad 4.55$ 

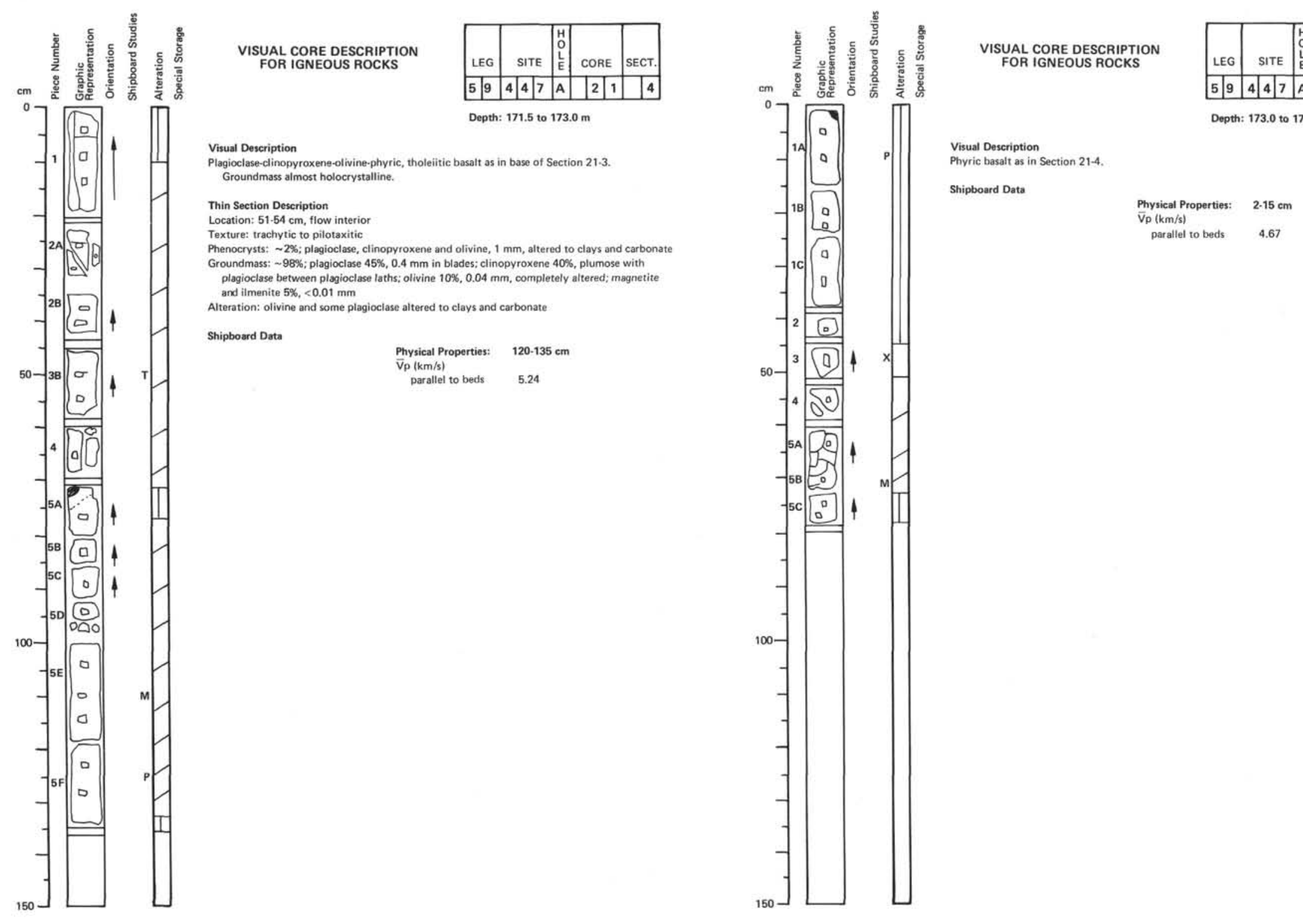


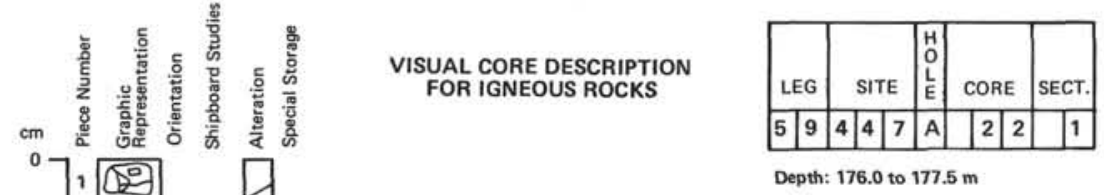

Visual Description

215. Aphanitic to very fine ophitic $80 \%$ crystalline with phenocrysts of altered olivine $<5 \%$, euhedral $1.2 \mathrm{~mm}$, in glomerocrysts. Abundant glassy rinds.

\section{Shipboard Dato
Bulk Analysis:}

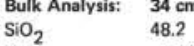

$34 \mathrm{~cm}$
48.2
1.14

$\nabla_{p}(\mathrm{~km} / \mathrm{s})$

parallel to becs
vertical to bed

$30.44 \mathrm{~cm}$

$\mathrm{Al}_{2} \mathrm{O}_{3}$

1.7
1.38
9.14

$\begin{array}{rr}\mathrm{MnO} & 0.16 \\ \mathrm{MgO} & 6.17 \\ \mathrm{CaO} & 12.85\end{array}$

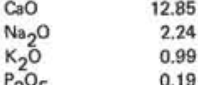

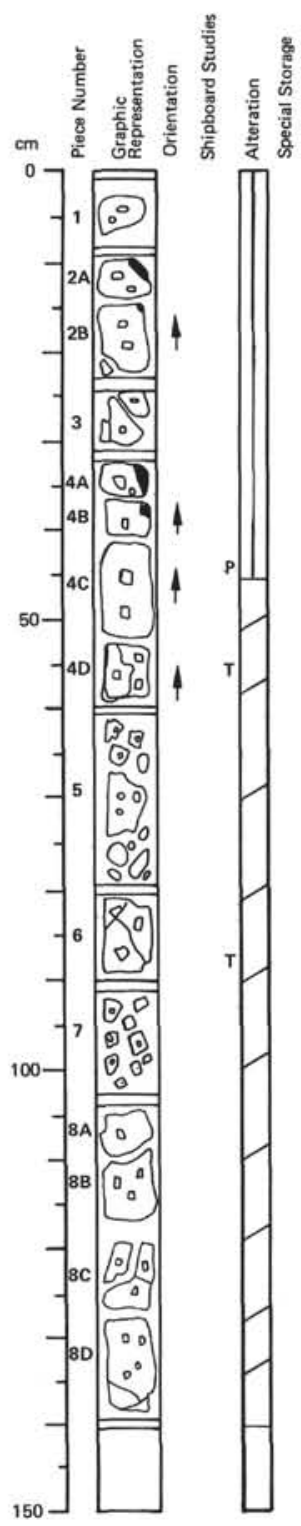

VISUAL CORE DESCRIPTION

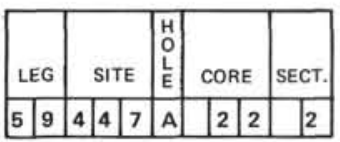

Depth: 177.5 to 179.0

\section{Visual Description}

Section 22.1, Phenocrysts

pear toward base of section.

Thin Section Description

Location: $56.58 \mathrm{~cm}$, flow interio

Texture: subvariolitic

An $0.5 \mathrm{~mm}$; clinopyroxene, rare; olivine, altered

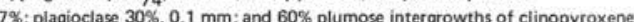
and plagioclase; magnetite and ilmenite $\sim 7 \%, 0.005 \mathrm{~mm}$

Alteration: plagioclase altered to carbonate; green smectite in scattered patches in groundmass: some iron oxides

Thin Section Description

Letion. $87.50 \mathrm{~cm}$, how interior

Phenocrysts: $5 \%$; plas

, $0.2 \cdot 0.4 \mathrm{~mm}$, more abundant than olivine, $0.6 \mathrm{~mm}$,

Groundmass: $95 \%$; plagioclase $50 \%,<0.2 \mathrm{~mm}$; clinopyroxene $45 \%$; $<0.02 \mathrm{~mm}$ Alteration: olivine altered to yellow and green smectites

Shipboard Date

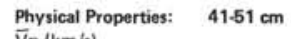

parallel to beds $\quad 4.7$ 

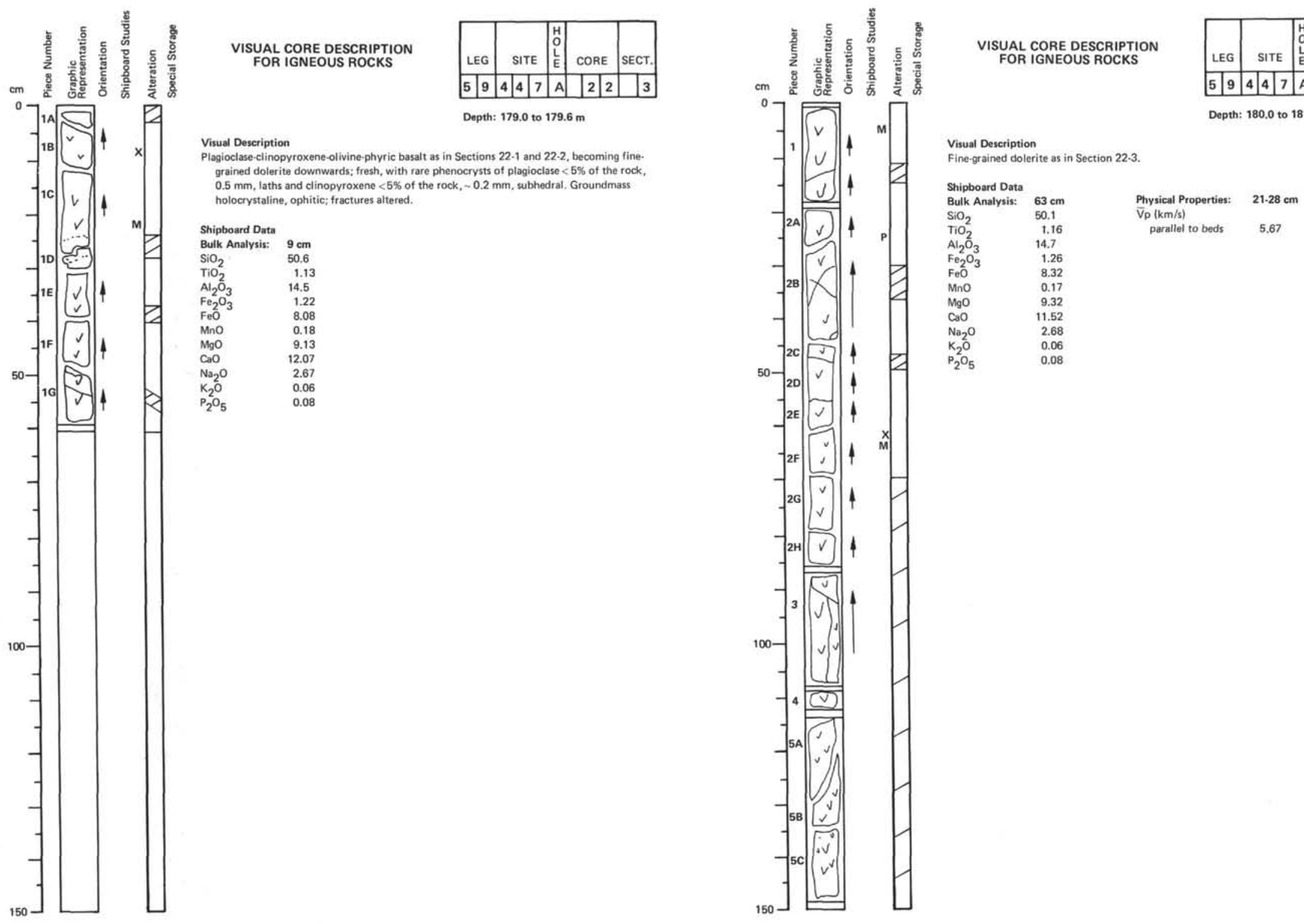

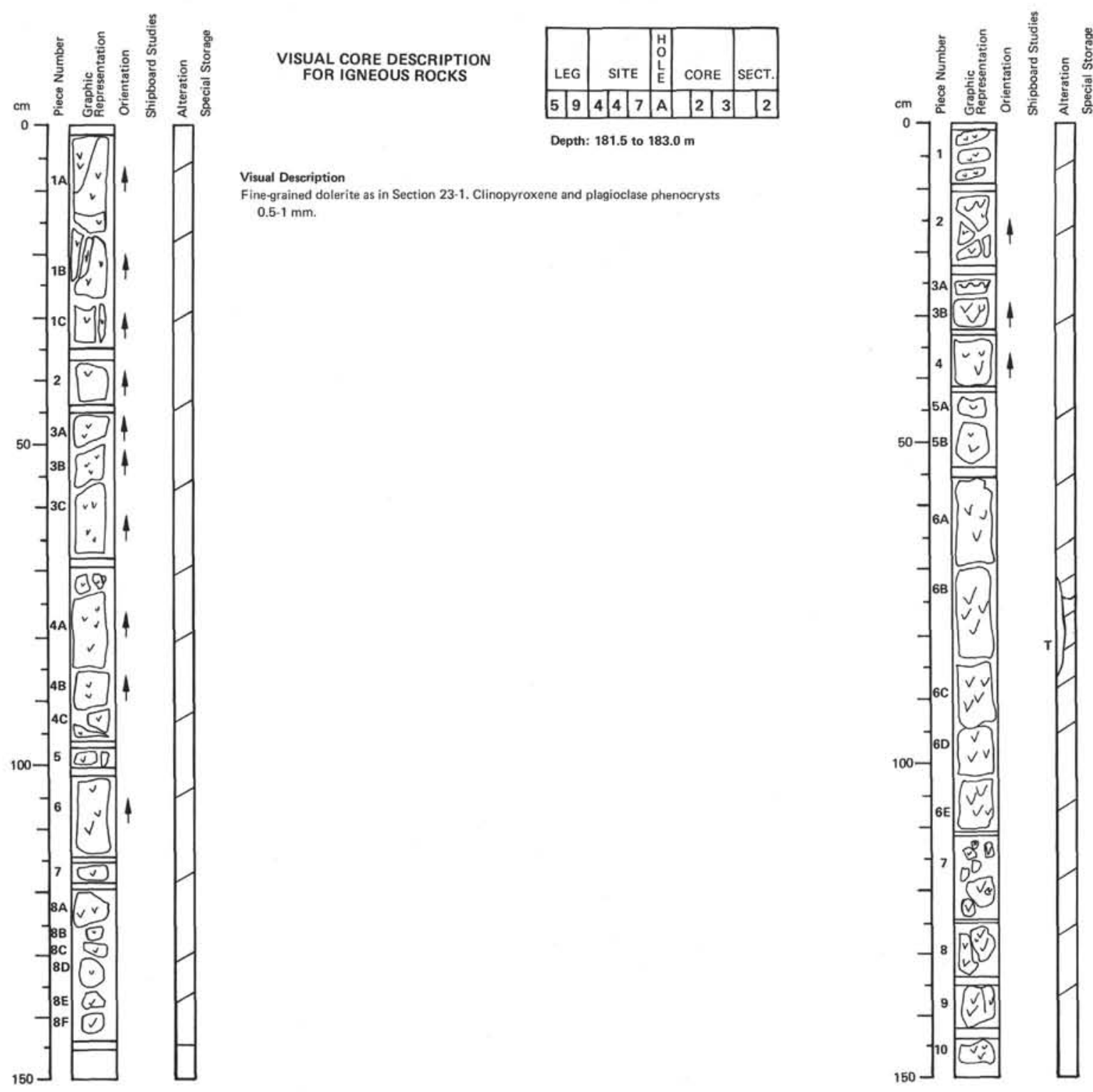 VISUAL CORE DESCRIPTION
FOR IGNEOUS ROCKS

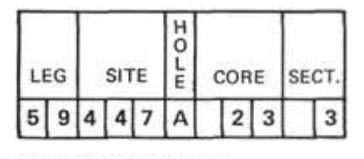

Visual Description

Fine grainestion that increase in quantity toward base.

Thin Section Description

Location: $81.83 \mathrm{~cm}$, flow interio

Phenocrysts: $5 \%$, plagioclase, $\mathrm{An}_{64^{+}}(p), 2 \mathrm{~mm}$; clinopyroxene, $1 \mathrm{~mm}$

pyross: $95 \%$, plagioclase $50 \%, A_{6} 67,<1 \mathrm{~mm}$, in plumose intergrowths with clino.

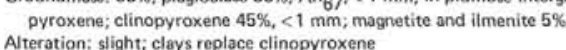



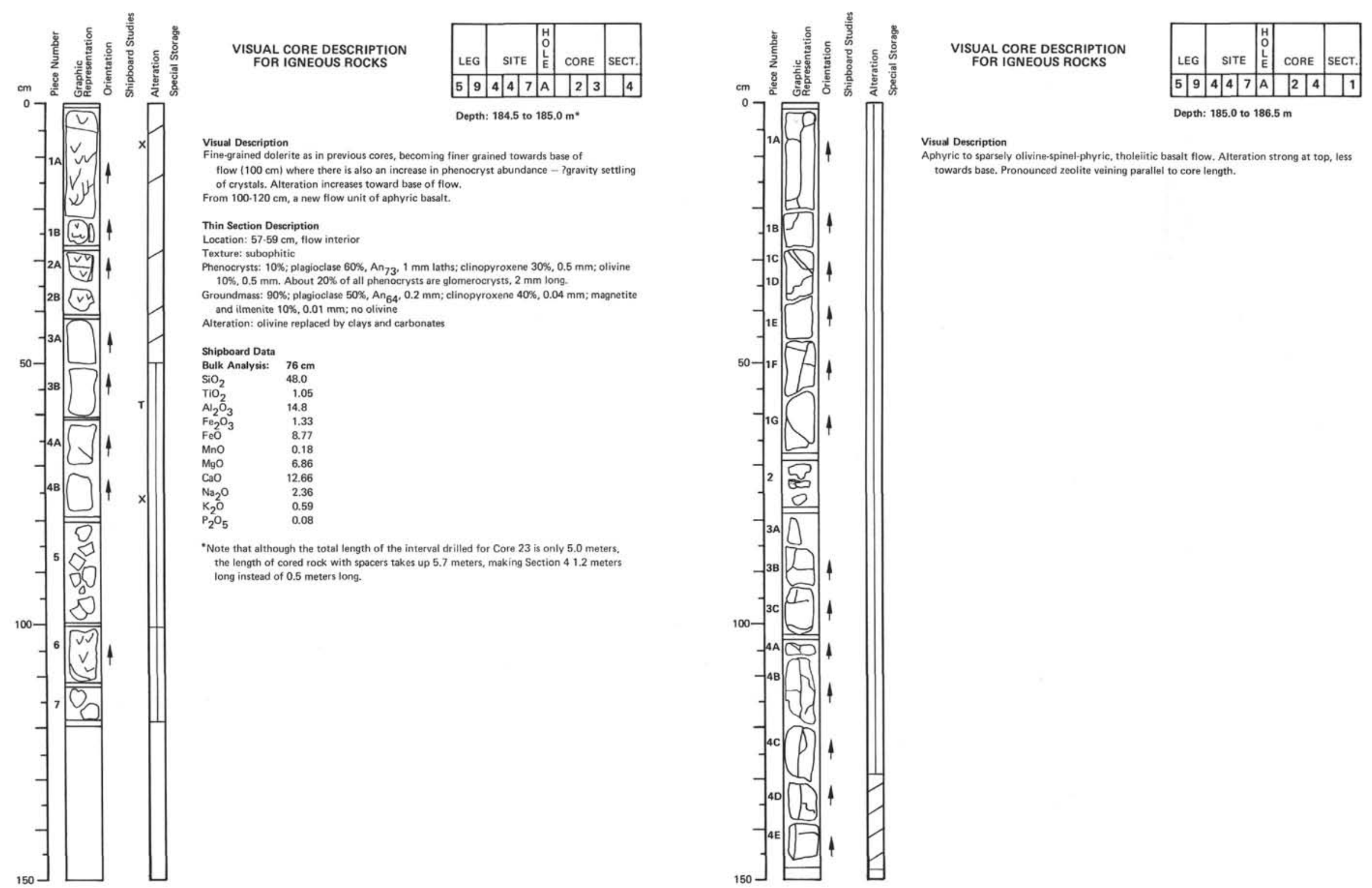

Visual Description

flow $(100 \mathrm{~cm})$ where there is also an increase in phenocryst abundance - ? gravity settling (n)

Thin Section Description

Location: $57.59 \mathrm{~cm}$, flow interio

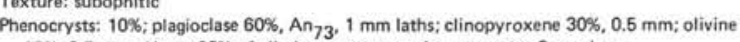

Groundmass: $90 \%$; plagioclase $50 \%, \mathrm{An}_{64}, 0.2 \mathrm{~mm}$; clinopyroxene $40 \%, 0.04 \mathrm{~mm}$; magnetite and ilmenite $10 \%, 0.01 \mathrm{~mm}$; no olivine

tion: olivine replaced by clays and carbonates

Shipboard Data

Bulk Analysis: $76 \mathrm{~cm}$

$\mathrm{SiO}_{2} \quad 48.0$

$\mathrm{Al}_{2} \mathrm{O}_{3} \quad 14.8$

$\mathrm{Fe}_{2} \mathrm{O}_{3} \quad 1.33$

$\mathrm{MnO} \quad 0.18$

$\begin{array}{rr}\mathrm{MgO} & 6.86 \\ \mathrm{CaO} & 12.66\end{array}$

$\begin{array}{ll}\mathrm{Na}_{2} \mathrm{O} & 2.36 \\ \mathrm{~K}_{2} \mathrm{O} & 0.59\end{array}$

"Note that although the total length of the interval drilled for Core 23 is only 5.0 meters long instead of 0.5 meters long

Visual Description

. Alteration strong at top, less A 

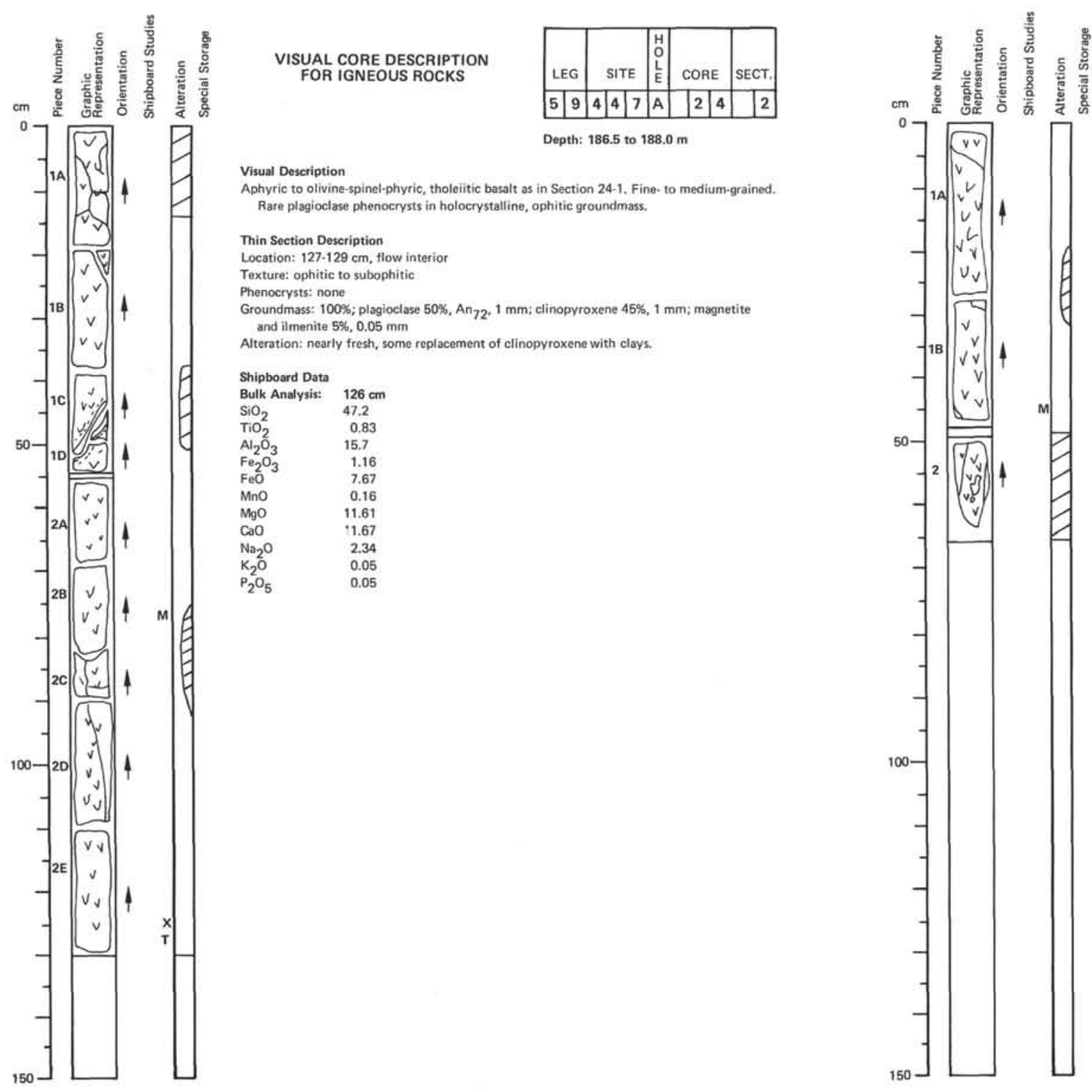
VISUAL CORE DESCRIPTION FOR IGNEOUS ROCKS

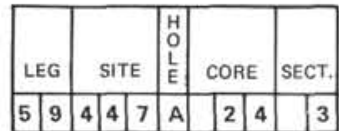
Depth: 188.0 to $188.6 \mathrm{~m}$

Visual Description

Aphyric thole eiitic basalt flow as in Section 24.2

Shipboard Data

Physical Properties: $\quad 42-45 \mathrm{~cm}$

parallel to beds
vertical to beds

$\mathrm{SiO}$

47.2

15.7

0.16

11.67

$\begin{array}{ll}\mathrm{a}_{2} \mathrm{O} & 2.3 \mathrm{O} \\ \mathrm{K}_{2} \mathrm{O} & 0.05\end{array}$

180$$
150
$$ 


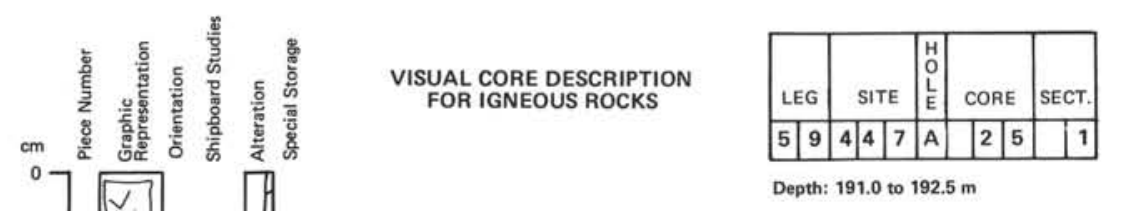

Aphyric to sparsely olvine-spinel-phyric tholeititic basalt as in Sections 24-1, 24-2, and 24-3. Rare plagioclase laths. Rock very fresh and unveined.

Shipboard Data
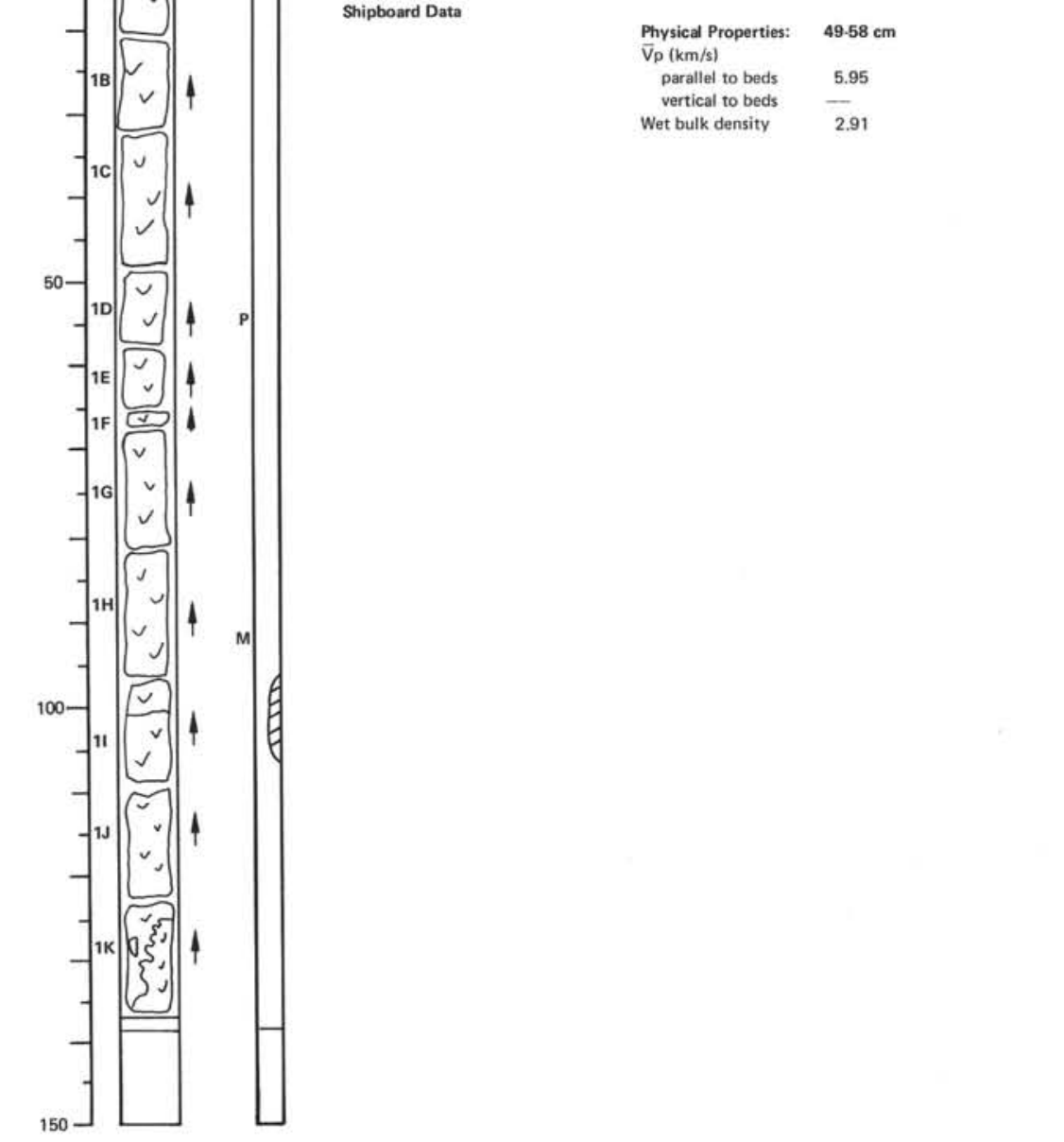

VISUAL CORE DESCRIPTION
FOR IGNEOUS ROCKS

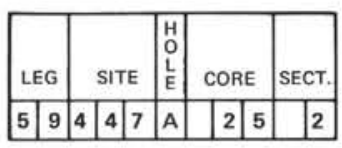

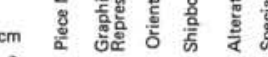

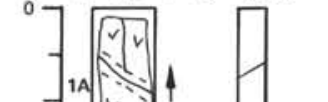

\begin{tabular}{|l|l|l|l|l|l|l|l|l|}
\hline 5 & 9 & 4 & 4 & 7 & A & 2 & 5 & \\
\hline
\end{tabular}

Depth: 192.5 to $194.0 \mathrm{~m}$

Visual Description

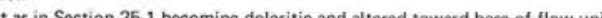
$(125 \mathrm{~cm})$ wher towards base. glassy margin.

Shipboard Data

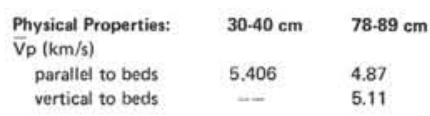




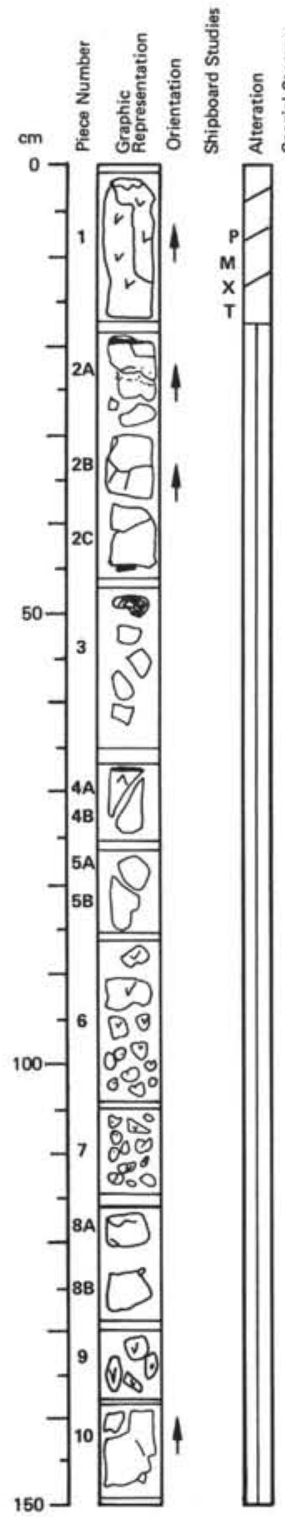

VISUAL CORE DESCRIPTION FOR IGNEOUS ROCKS

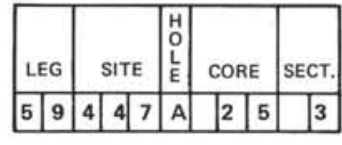

Visual Description

Copyroxene-phyric tholeitic basalt pillowed massive flows

From $0.17 \mathrm{~cm}$, fine-grained sparsely olivine-phyric basalt. Below $17 \mathrm{~cm}$, a pillowed sequence of extremely altered, fine-grained to glassy basalt with fresh, black, glassy rims. Contains ocrysts of euhedral to subhedral olivine $<1 \%$ of the rock, $\sim 1 \mathrm{~mm}$, altered and rare laths of plagioclase are present.

Thin Section Description

ow interior

clinopyroxene $55 \%$, finely plumase with plagioclase; magnetite and ilmenite $5 \%, 0.02 \cdot 0.05 \mathrm{~mm}$

Vesicles: $2 x, 0.05 \mathrm{~mm}$, irregular, illed with brown smectite laths are altered.

Shipboard Dat:

$\begin{array}{ll}\text { Bulk Analysis: } & 10 \mathrm{~cm} \\ \mathrm{SiO}_{2} & 47.5 \\ \mathrm{H}_{2} & 0.91\end{array}$

$10 \mathrm{~cm}$
47.5
0.91

Physical Propertie

$7.10 \mathrm{~cm}$

$\mathrm{THO}^{2}$

0.91
16.9

$\mathrm{Vp}(\mathrm{km} / \mathrm{s})$

$\begin{array}{ll}\mathrm{Al}_{2} \mathrm{O}_{3} & 16.9 \\ \mathrm{Fe}_{2} \mathrm{O}_{3} & 1.22 \\ & \end{array}$

vertical to beds $\quad 5.21$

$\begin{array}{ll}\mathrm{FeO} & 8.02 \\ \mathrm{MnO} & 0.19\end{array}$

$\begin{array}{lr}\mathrm{MnO} & 0.19 \\ \mathrm{MgO} & 1.47 \\ \mathrm{CaO} & 12.252\end{array}$

\begin{tabular}{ll}
$\mathrm{CaO}_{\mathrm{C}}$ & $1.2 \mathrm{O}$ \\
$\mathrm{N}_{\mathrm{N}_{2} \mathrm{O}}$ & $\mathbf{2 . 2 0}$ \\
$\mathrm{P}_{2} \mathrm{O}$ & 2.52 \\
\hline
\end{tabular}

$\begin{array}{ll}\mathrm{K}_{2} \mathrm{O} & 0.58 \\ \mathrm{P}_{2} \mathrm{O}_{5} & 0.05\end{array}$

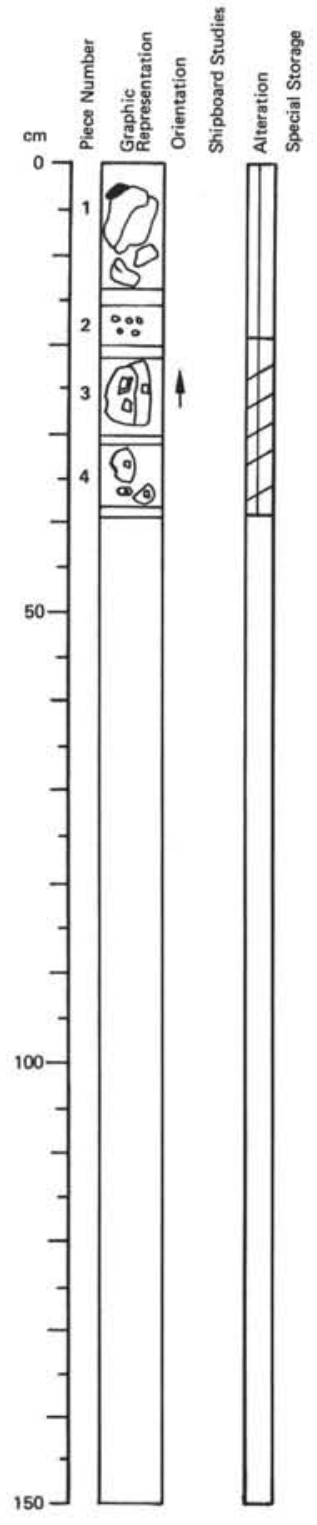

VISUAL CORE DESCRIPTION

FOR IGNEOUS ROCKS

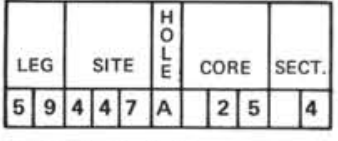

Visual Descriptio 


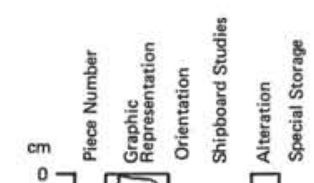

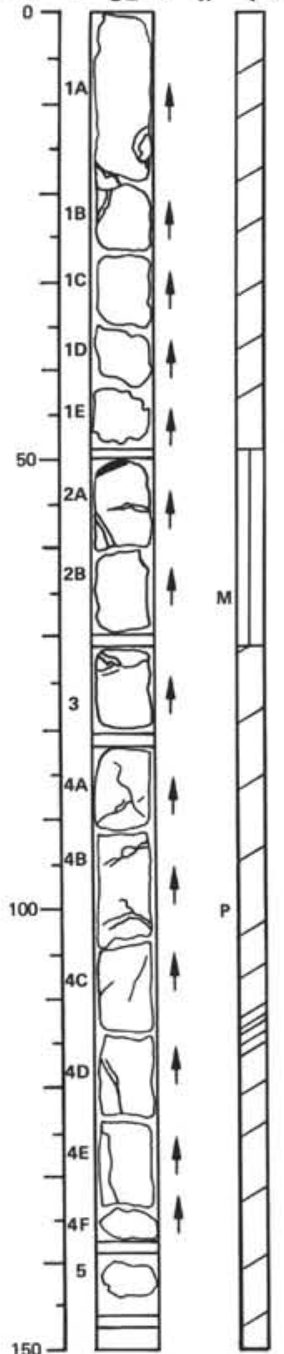

VISUAL CORE DESCRIPTION

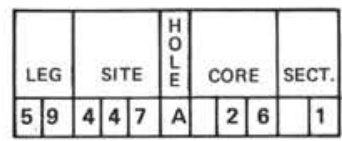

Visual Description

25.

From $50.70 \mathrm{~cm}$ extremely attered with thin $(0.7 \mathrm{~mm})$ rim of glass completely altered to

smectite.

Physical Propertios:

$92.104 \mathrm{~cm}$

4.12
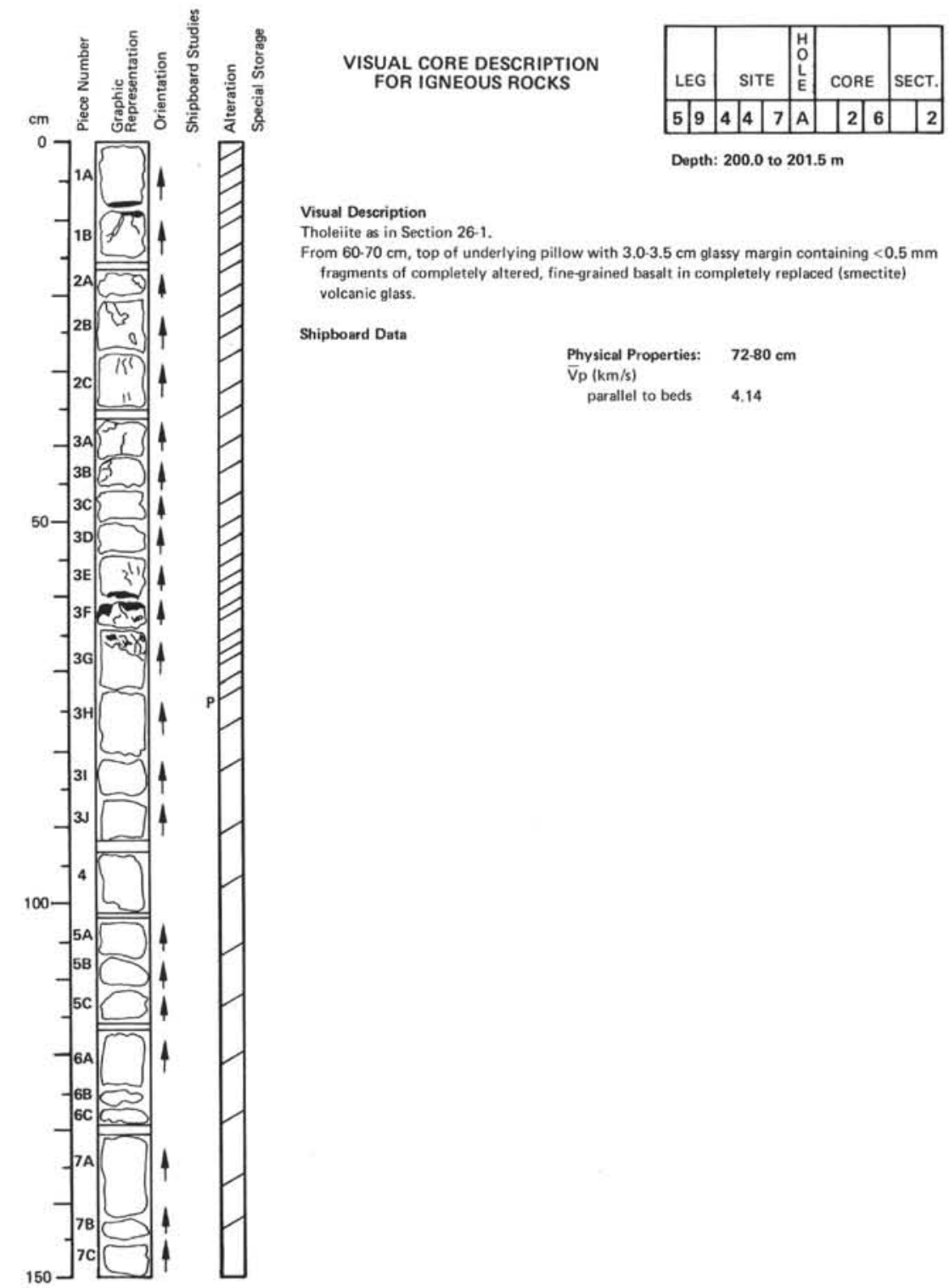

Visual Description

rain containing $<0.5 \mathrm{~mm}$ (smectite) volcanic glass

Shipboard Data

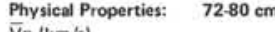

40 


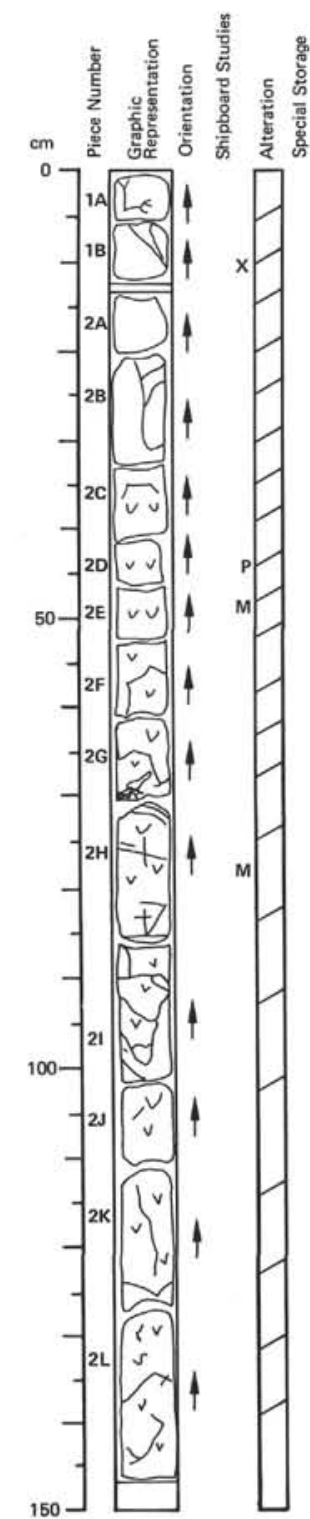

VISUAL CORE DESCRIPTION FOR IGNEOUS ROCKS

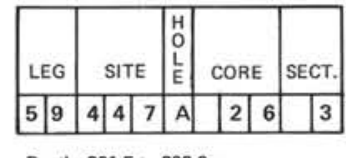

Visual Description

26-1 and 26-2; gray (7.5YR 6/0) with pale brown altered patches: zed; veined $\{0.3 .0 .5 \mathrm{~mm}$ ) with carbonates and zeofites. (terval 2C through $2 E$ is to subophitic with intergranular altered glass. Shipboard Data

$$
\begin{aligned}
& \text { Physical Properties: } \quad 42-47 \mathrm{~cm} \\
& \bar{V}_{p}(\mathrm{~km} / \mathrm{s})
\end{aligned}
$$$$
\begin{aligned}
& \text { parallel to beds } \\
& \text { vertical to beds }
\end{aligned}
$$$$
4.51
$$

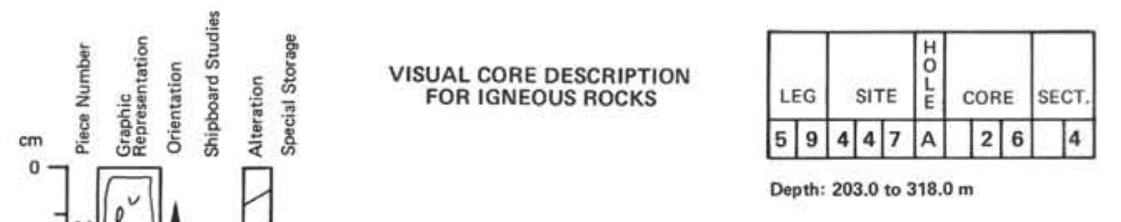

Visual Description

$26-1,26-2,2$ and 26.3 , trom $0.60 \mathrm{~cm}$ . Segments $3 A$ through 38 are aphyric with olassy rim, $1.3 \mathrm{~cm}$, totally replaced with green, zonal smectite and veined with carbonates and zeolites, $<0.5 \mathrm{~mm}$. Shipboard Data Physical Propes
$\bar{V} p(\mathrm{~km} / \mathrm{s})$
paralls parallel to beds
Ded 23-37 c $89.93 \mathrm{~cm}$ 

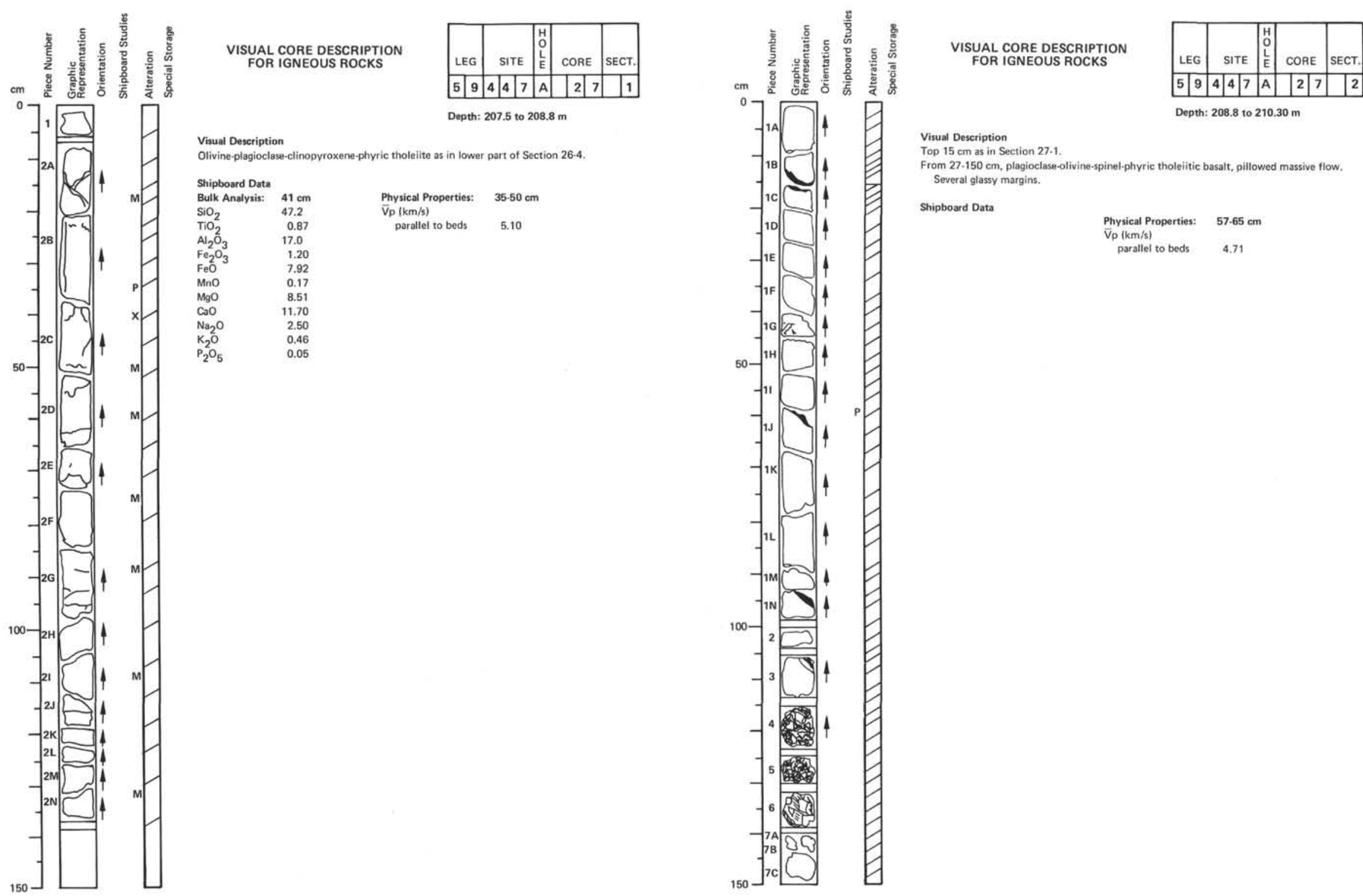

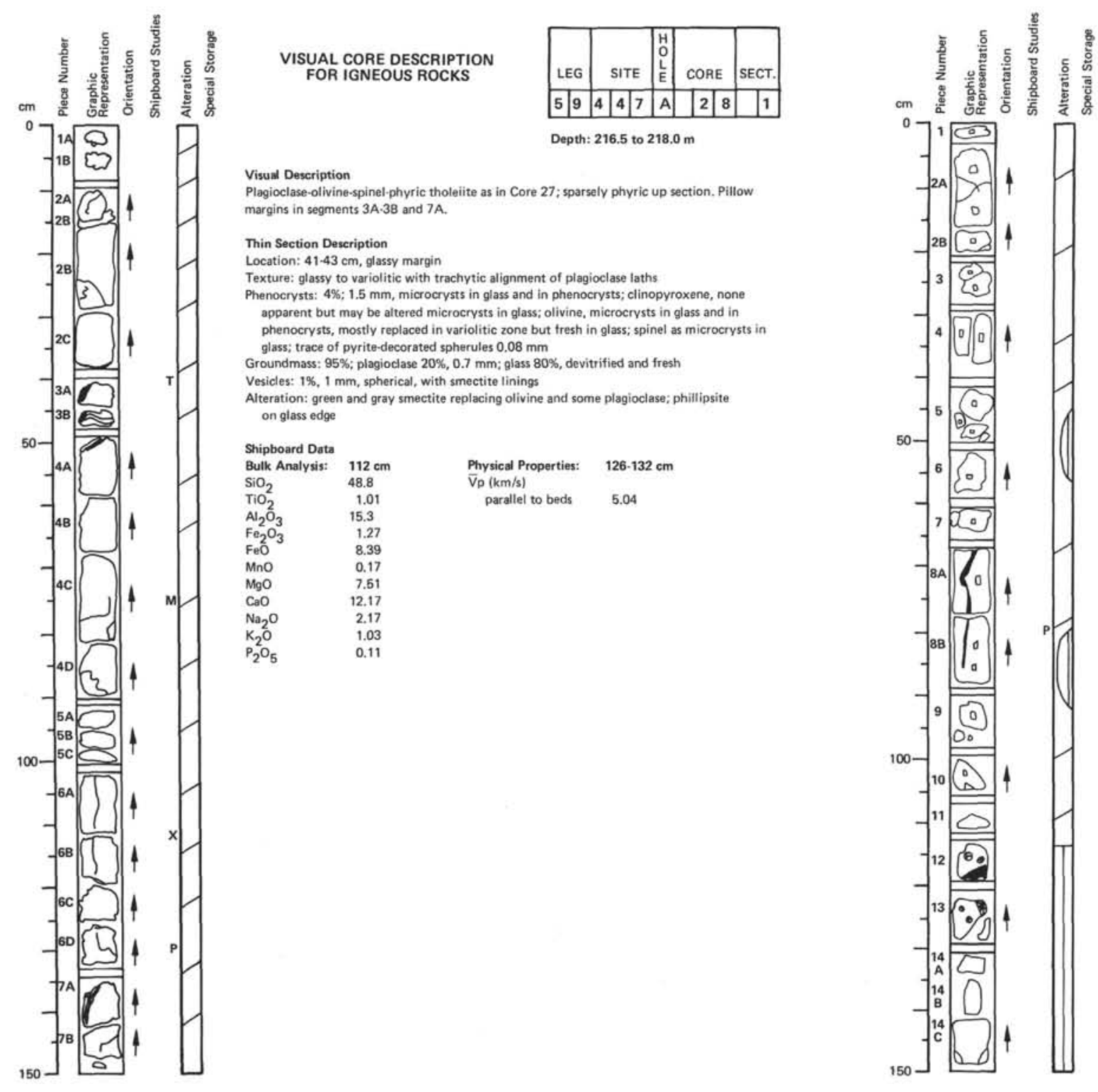
VISUAL CORE DESCRIPTION
FOR IGNEOUS ROCKS

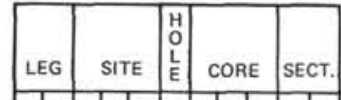 \begin{tabular}{|l|l|l|l|l|l|l|l|}
\hline 5 & 9 & 4 & 4 & 7 & $A$ & 2 & 8 \\
\hline
\end{tabular}
Depth: 218.0 to $219.5 \mathrm{~m}$

Visual Description

Vric tholeftic basalt as in Section 28.1. Groundmass $~-80 \%$, holocrystalline, aphanitic to finely ophitic, variolitic near glassy margins. Scattered vesicles $<1 \mathrm{~mm}$, partiy filled with green smectite. Olivine phenocrysts entirely altered to iddingsite, up to $2 \mathrm{~mm}, 5.10 \%$ of Shipboard Dats

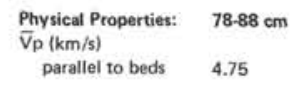



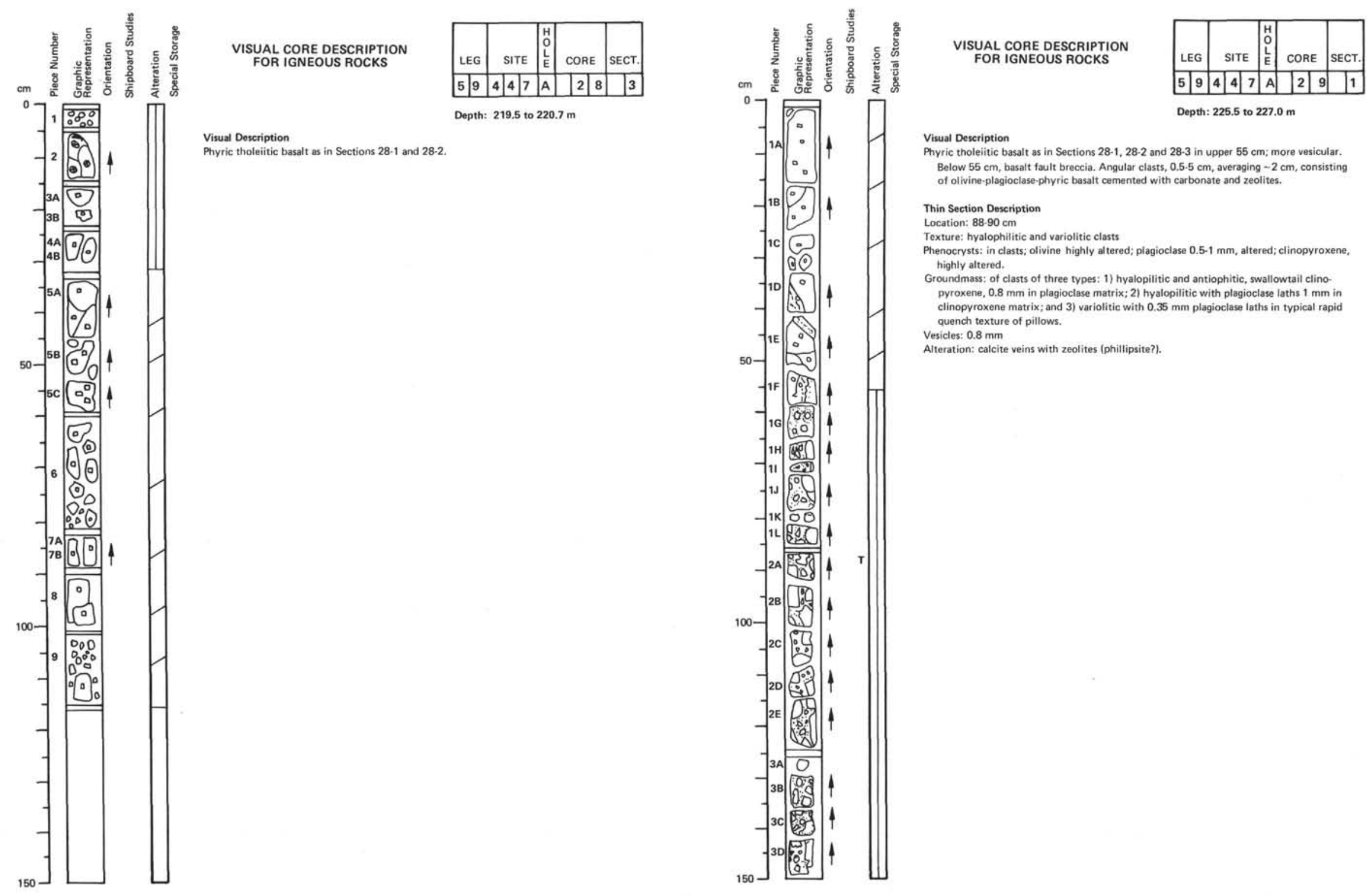

Visual Description

basalt as in Sections 28-1, 28.2 and 28.3 in upper $55 \mathrm{~cm}$ more vesicular. Below $55 \mathrm{~cm}$, basalt fault breccia. Angular clasts, $0.5 .5 \mathrm{~cm}$, averaging $2 \mathrm{~cm}$, consisting se-phyric basalt cemento

Thin Section Description

Location: $88.90 \mathrm{~cm}$

Phenocrysts: in clasts: oflivine highty clasts highly altered.

Groundmass: of clasts of three types: 1) hyalopilitic and antiophitic, swallowtail clino. pyroxene, $0.8 \mathrm{~mm}$ in plagioclase matrix;2) hyalopilitic with plagioclase laths $1 \mathrm{~mm}$ i Clinopyroxene matrix; and 3 ) variolitic with $0.36 \mathrm{~mm}$ plagioclase laths in typical rapid

Alteration: calcite veins with zeolites (phillipsite?). 


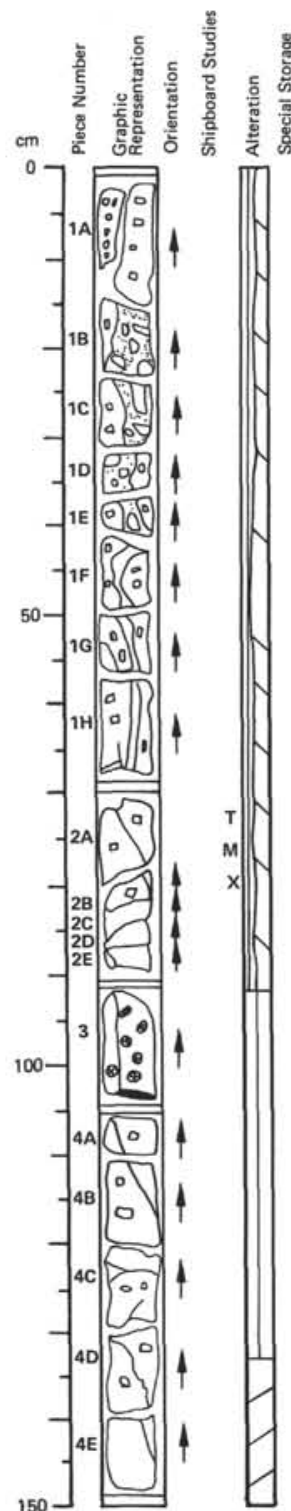
VISUAL CORE DESCRIPTION
FOR IGNEOUS ROCKS

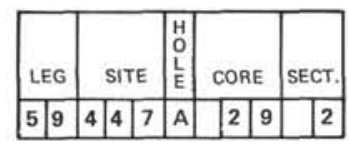

Depth: 227.0 to $228.5 \mathrm{~m}$

Virual Description

Basalt tault treccia in upper $50 \mathrm{~cm}$ as in Section 29.1.

From 50-105 cm: plagioclase-olivine-spinel-phyric tholeiitic basalt as in Section 28-3.

Frocomes variolitic towards glassy base.

\section{Thin Section Description}

Location: $71.73 \mathrm{~cm}$, flow interior

Phenocrysts: 4.5\%; olivine 50.60\%, 1.0.1.5 mm, euhedral pseudomorphs; plagioclase $40.50 \%$ $-1.2 \mathrm{~mm}$, subhedral, completely altered

Groundmass: > 90\%; plagioclase 50\%, $\mathrm{An}_{67},<1 \mathrm{~mm}$, elongate laths; clinopyroxene $30 \%, 0.1$

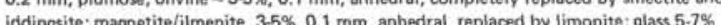
Vesicles: $3-5 \%, 0.4-0.5 \mathrm{~mm}$, spheroidal, filled with smectite, zeolites, carbonates

Alteration: carbonate veins 2-3\%; clays and zeolites altering glass and olivine

Shipboard Data

$\begin{array}{lccl}\text { Shipboard Data } & & \text { Physical Properties: } & 74.76 \mathrm{~cm} \\ \text { Bulk Analysis: } & 80 \mathrm{~cm} & \begin{array}{c}\text { Phy } \\ \mathrm{V}_{\mathrm{p}}(\mathrm{km} / \mathrm{s})\end{array} \\ \mathrm{SiO}_{2} & 49.2 & \text { paral to beds } & 5.15 \\ \mathrm{TiO}_{2} & 0.94 & \text { vertical to beds } & 5.28 \\ \mathrm{Al}_{2} \mathrm{O}_{3} & 15.7 & & \\ \mathrm{Fe}_{2} \mathrm{O}_{3} & 1.19 & & \\ \mathrm{FeO} & 7.88 & & \\ \mathrm{MnO} & 0.17 & & \\ \mathrm{MgO} & 8.55 & & \\ \mathrm{CaO} & 12.44 & & \\ \mathrm{Na}_{2} \mathrm{O} & 2.31 & & \\ \mathrm{~K}_{2} \mathrm{O} & 0.44 & & \\ \mathrm{P}_{2} \mathrm{O}_{5} & 0.08 & & \end{array}$

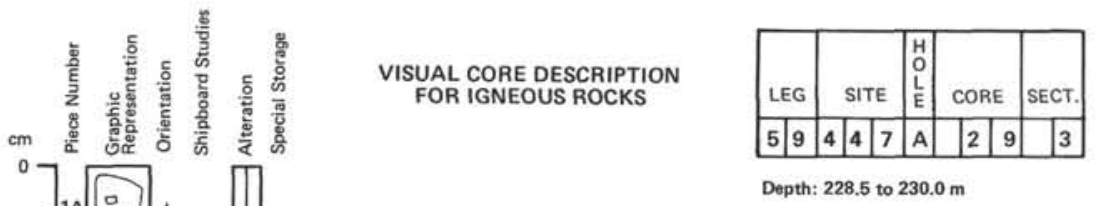

Visual Description

0.20 125 plagioclass-olivine-spinel-phyric tholeite flow as in basal $45 \mathrm{~cm}$ of Section $29 \cdot 2$. grained aphanitic groundmass, variolitic near chilled contacts. Pyroxene phenocrysts dark green, subhedral, $<10 \%$ of the rock, $1.2 \mathrm{~mm}$ concentrated near top of unit, Pisgioclase $1.2 \mathrm{~mm}$, rare. Olivine, altered to iddingsite, concentrated in basal $10.20 \mathrm{~cm}$ of unit. 125-150 cm: plagioclass-olivine-phyric basalt with variolitic texture.

Thin Section Descriptio

Location: $32.33 \mathrm{~cm}$

some glomerocrysts)

Phenocrysts: 15\%; olivine, $1.2 \mathrm{~mm}$ highly resorbed, replaced by zeolites and Grouectite, plagioclass, $0.5 \mathrm{~mm}$, blocky: clinopyroxene, $0.35 \mathrm{~mm}$, spinel, trace

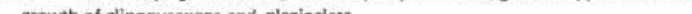

$\begin{array}{lrc}\text { Shipboard Data } & & \\ \text { Bulk Analysis: } & 15 \mathrm{~cm} & 51 \mathrm{~cm} \\ \mathrm{SiO}_{2} & 48.9 & 48.6 \\ \mathrm{TiO}_{2} & 0.92 & 0.95 \\ \mathrm{Al}_{2} \mathrm{O}_{3} & 15.1 & 15.6 \\ \mathrm{Fe}_{2} \mathrm{O}_{3} & 1.23 & 1.23 \\ \mathrm{FeO} & 8.11 & 8.13 \\ \mathrm{MnO} & 0.17 & 0.16 \\ \mathrm{MgO} & 8.08 & 6.57 \\ \mathrm{CaO} & 13.13 & 12.69 \\ \mathrm{Na}_{2} \mathrm{O} & 2.27 & 2.21 \\ \mathrm{~K}_{2} \mathrm{O} & 0.57 & 1.14 \\ \mathrm{P}_{2} \mathrm{O}_{5} & 0.09 & 0.10\end{array}$

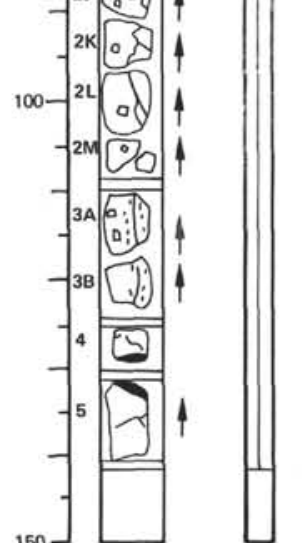



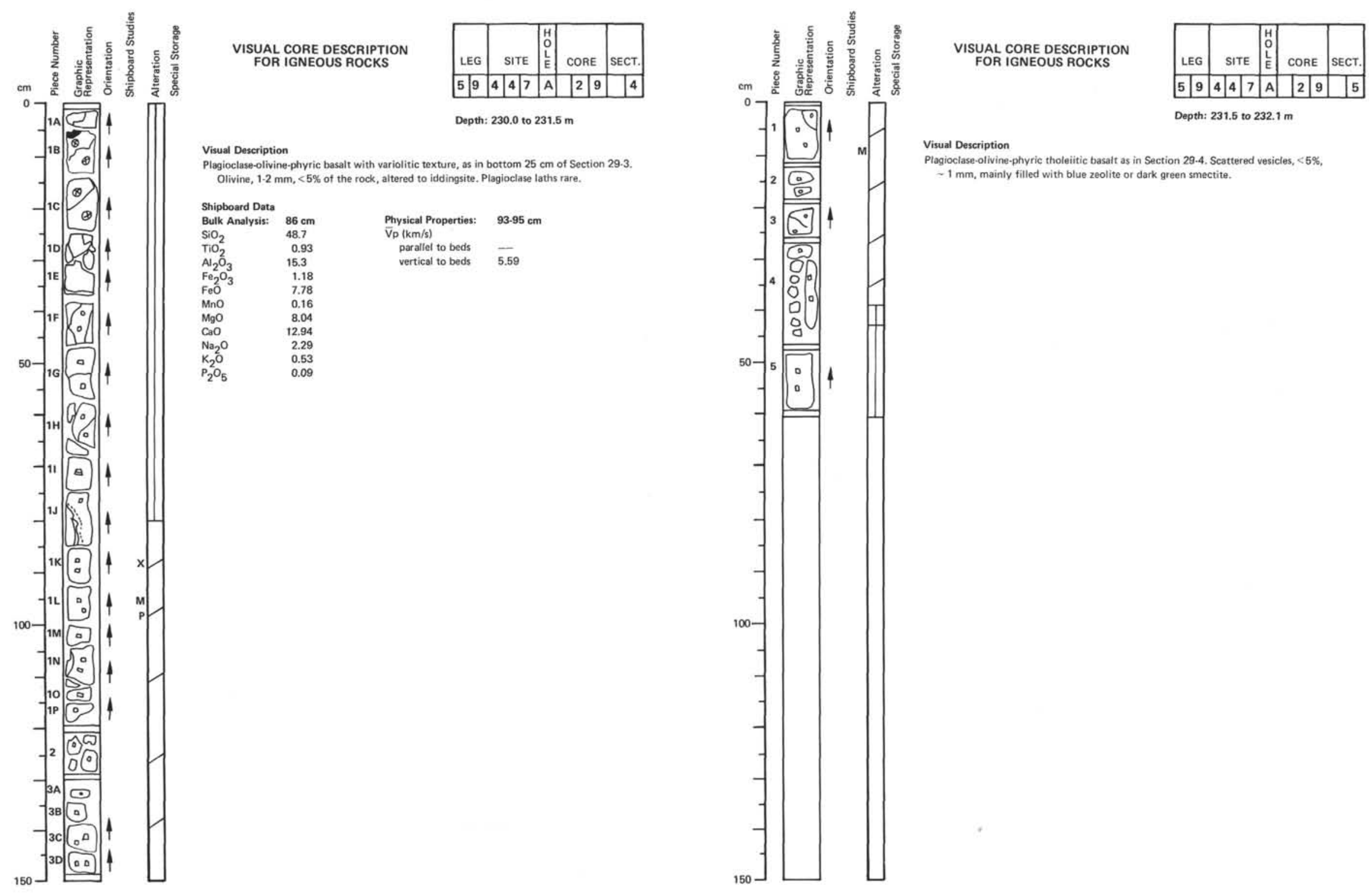

Visual Description

Plagioclase-olivine-phyric tholeitic basalt as in Section 29.4. Scattered vesicles, $<5 \%$, $\sim 1 \mathrm{~mm}$, mainly filled with blue zeolite or dark green smectite. 

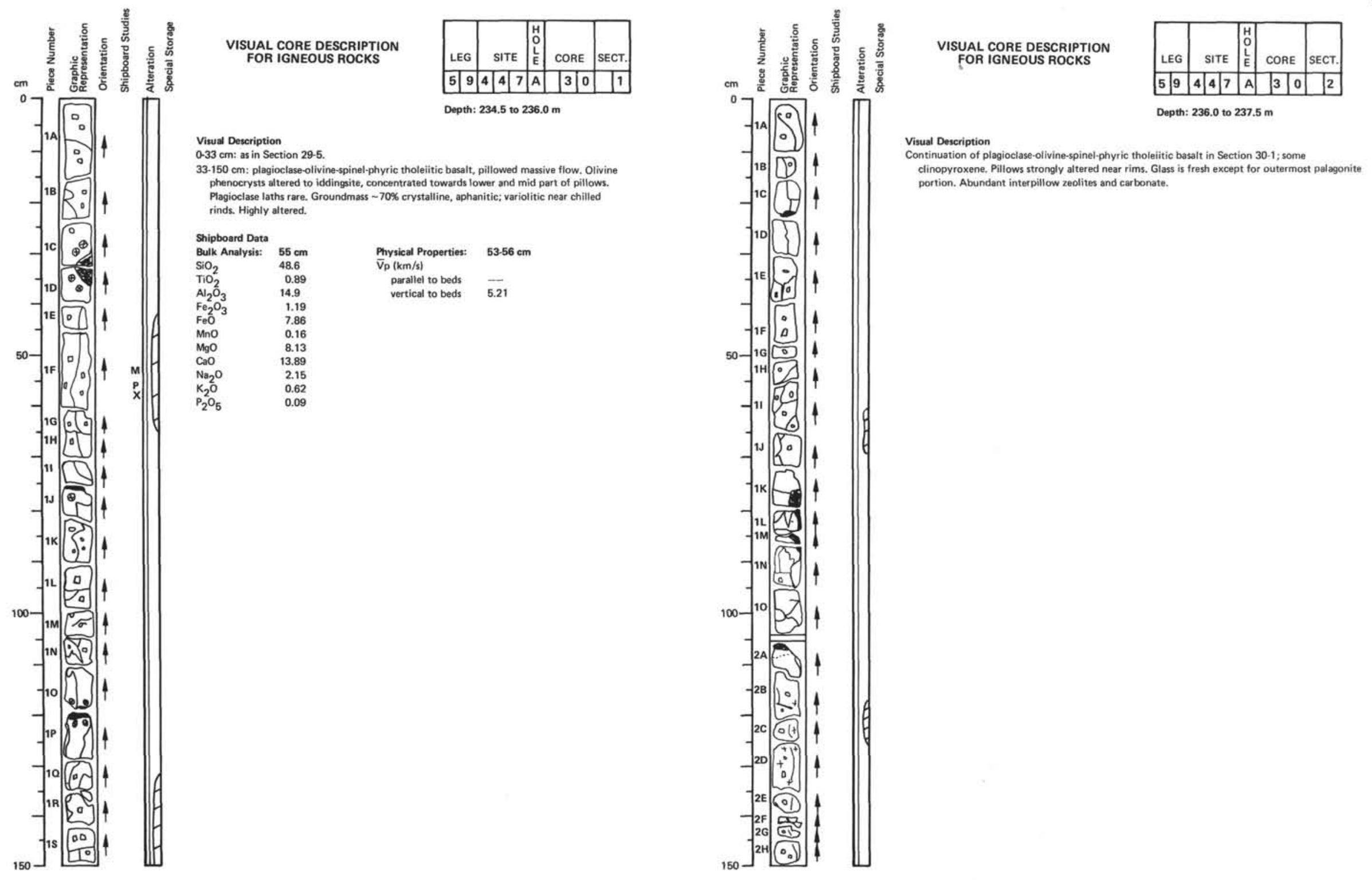

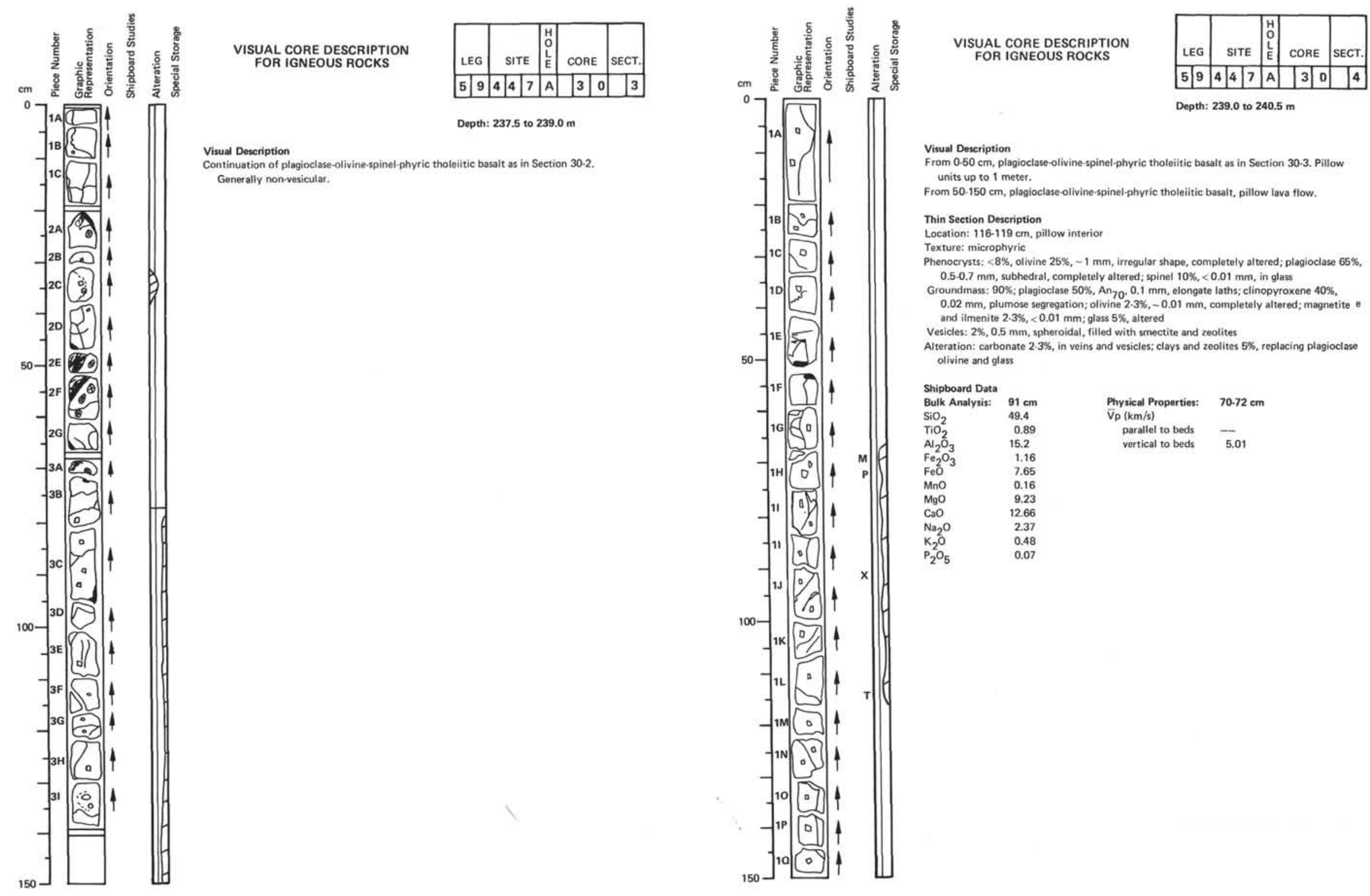

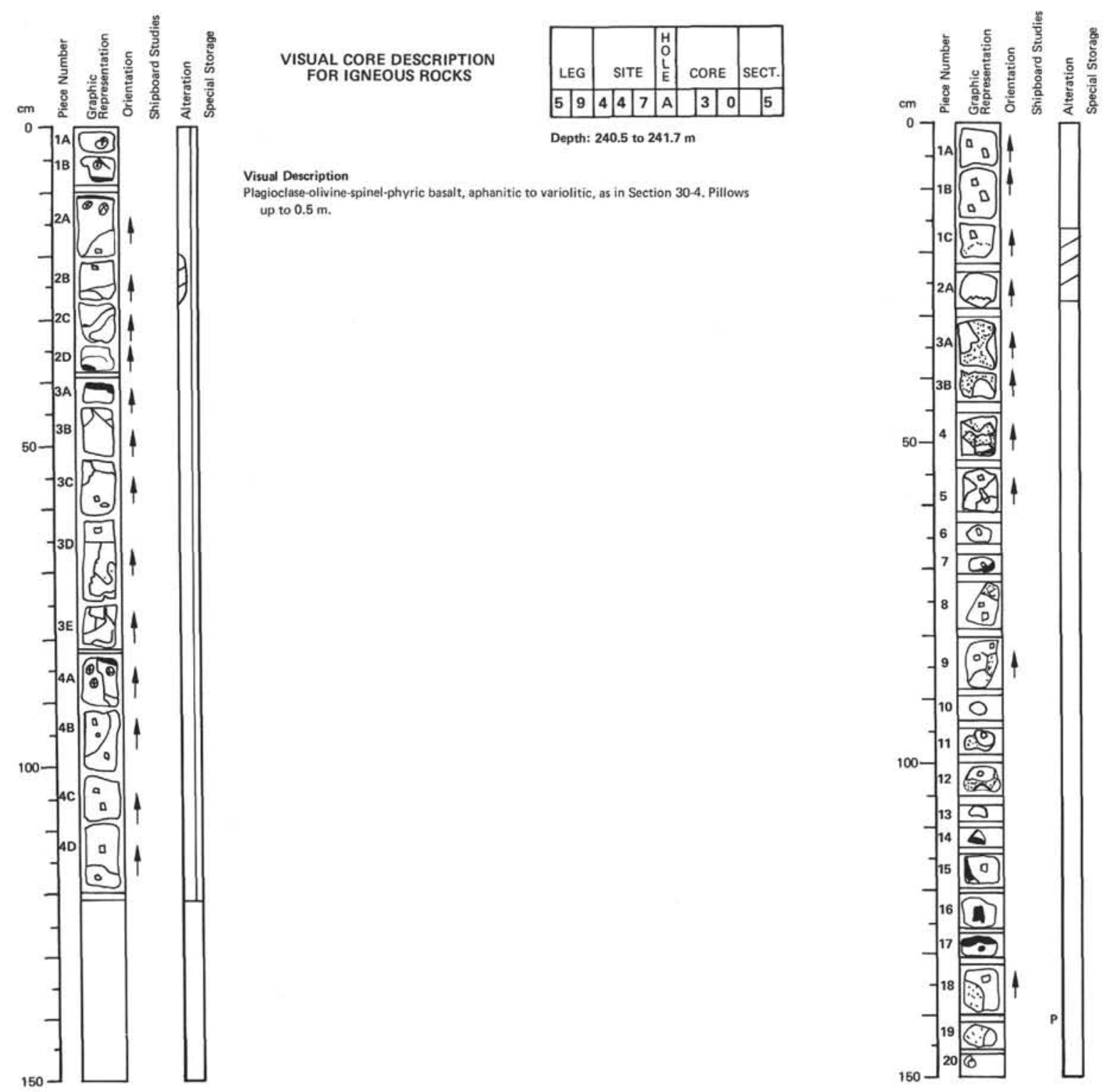

VISUAL CORE DESCRIPTION FOR IGNEOUS ROCKS

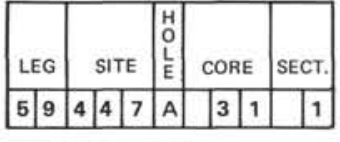

Visual Description

spinel-phyric basalt as in Section 30.5 . phric, aphanitic basalt set in a matrix of calcite, quartz and zeolites. Autobrecciation(?). 


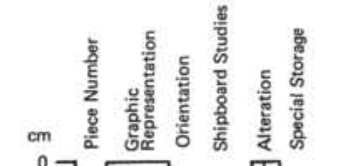

${ }^{\circ}$

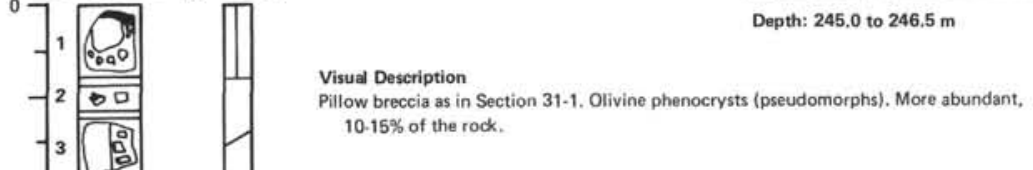

$10.15 \%$ of the rodk.

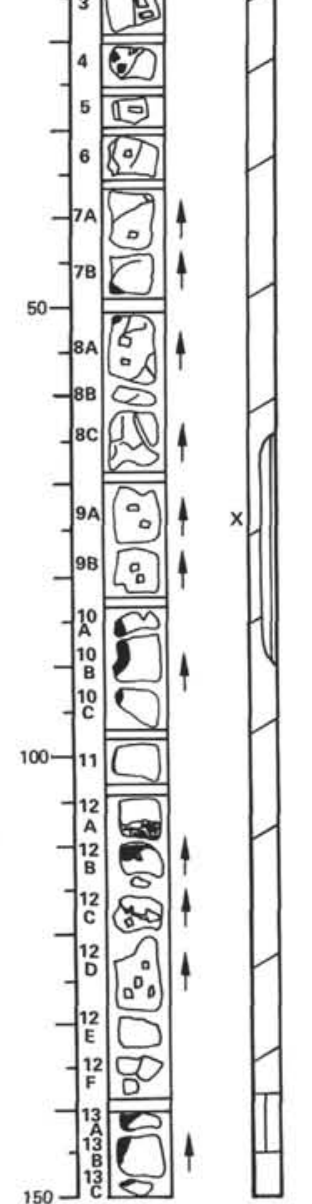

VISUAL CORE DESCRIPTION
FOR IGNEOUS ROCKS

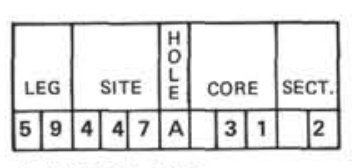

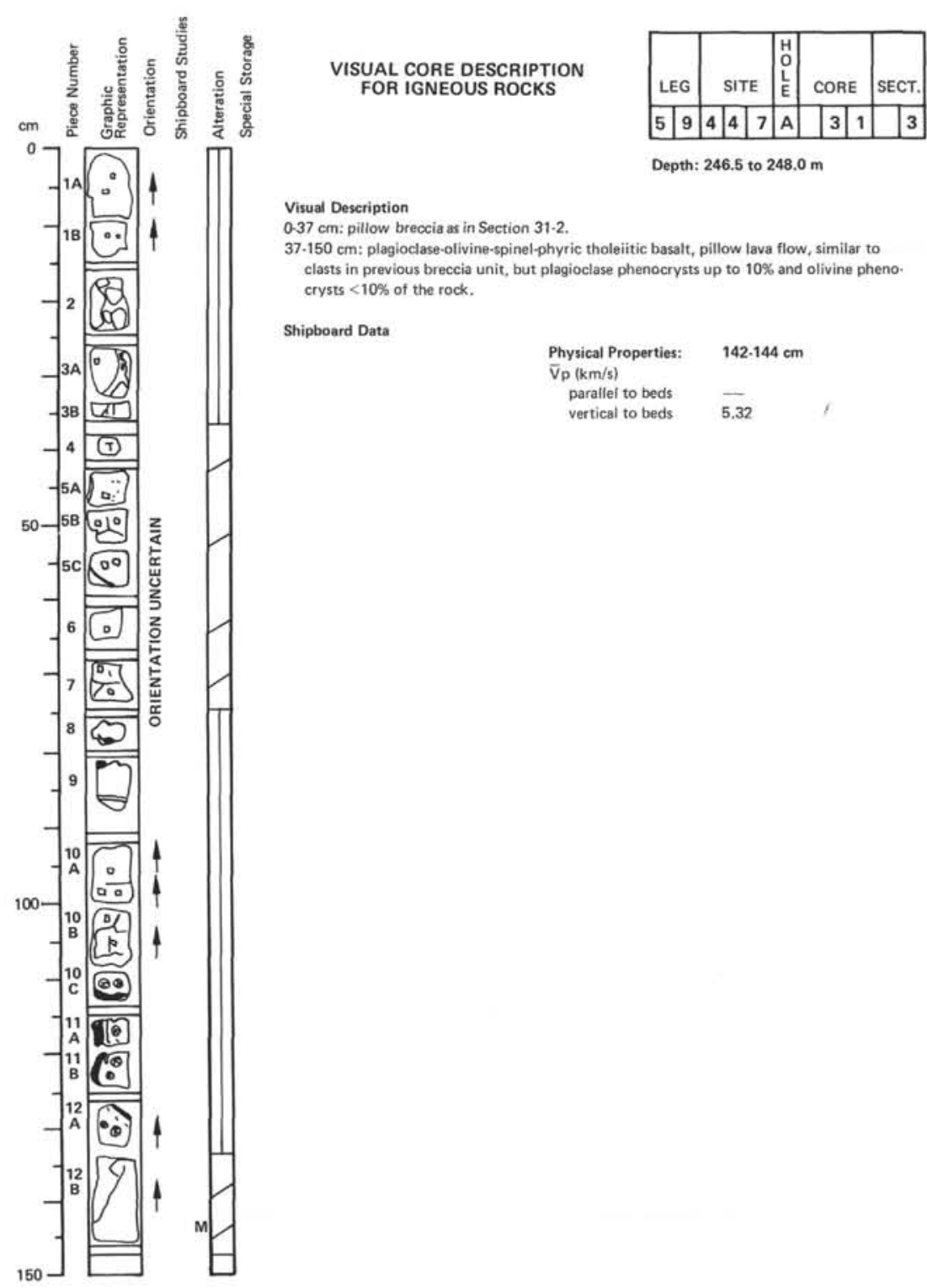



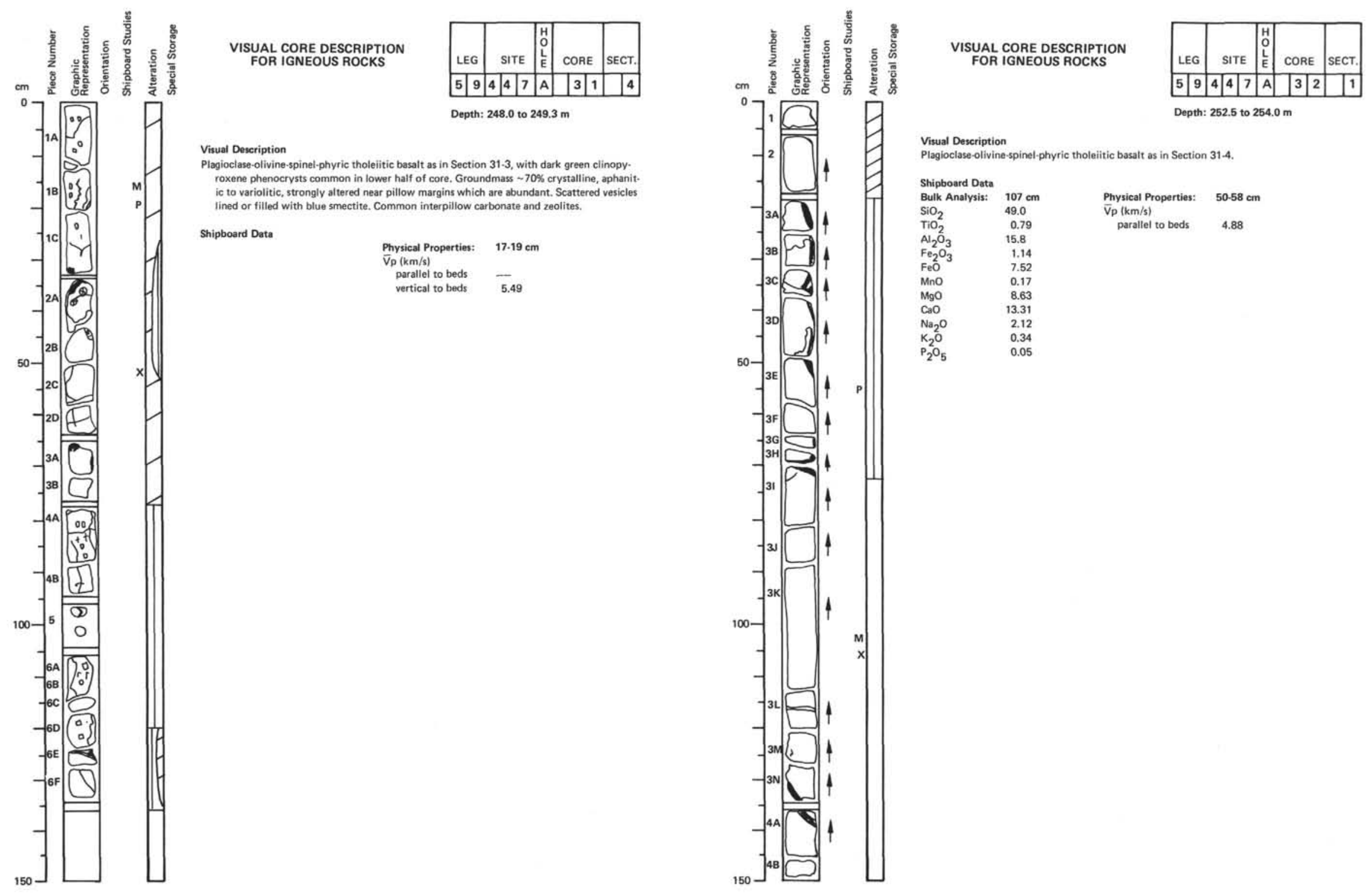

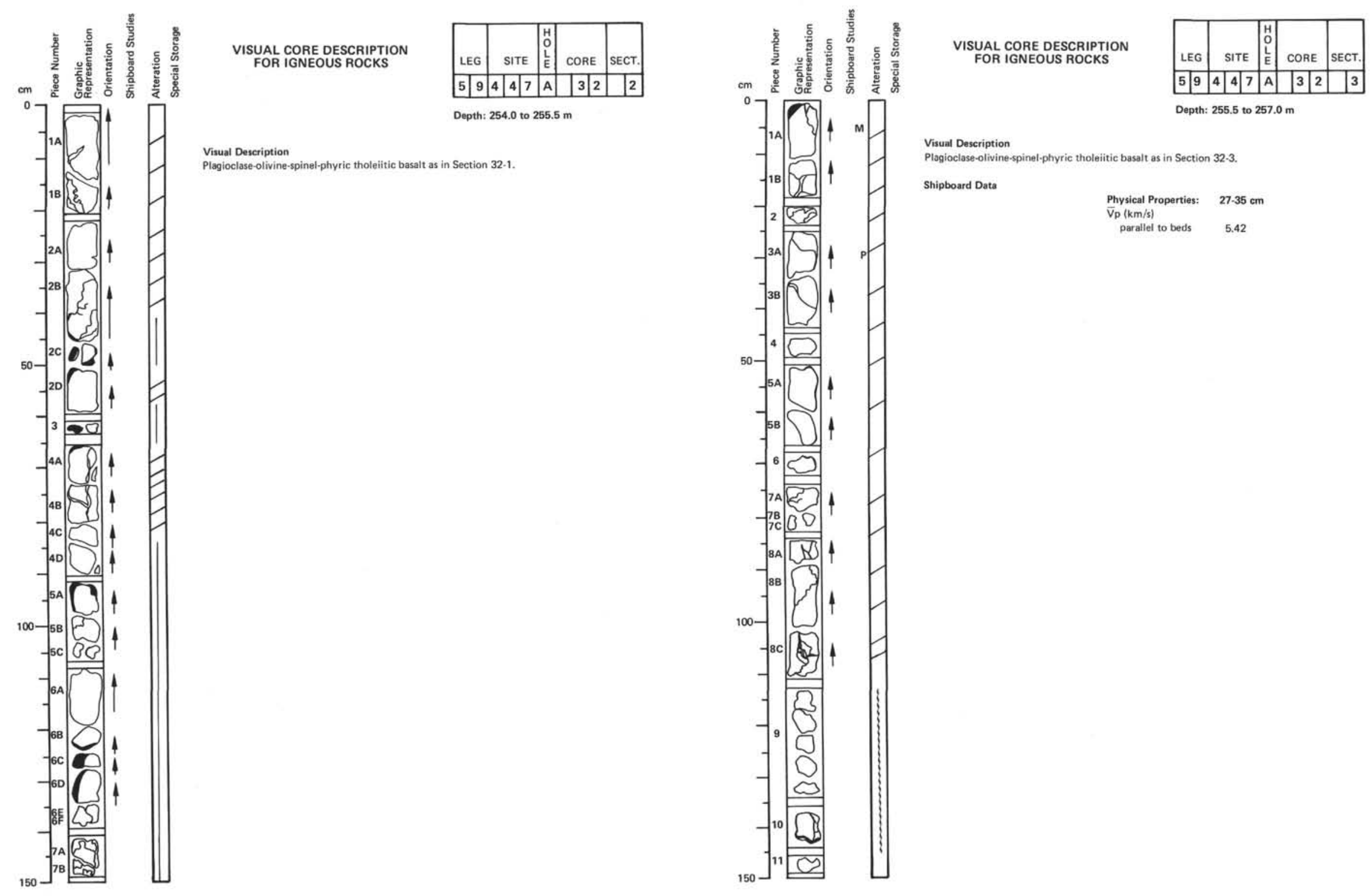

Visual Description

Plagioclose-olivine-spinel-phyric tholeititic basalt as in Section 32-3.

Shipboard Data

Physical Properties: $\quad 27.35 \mathrm{~cm}$

5.42 


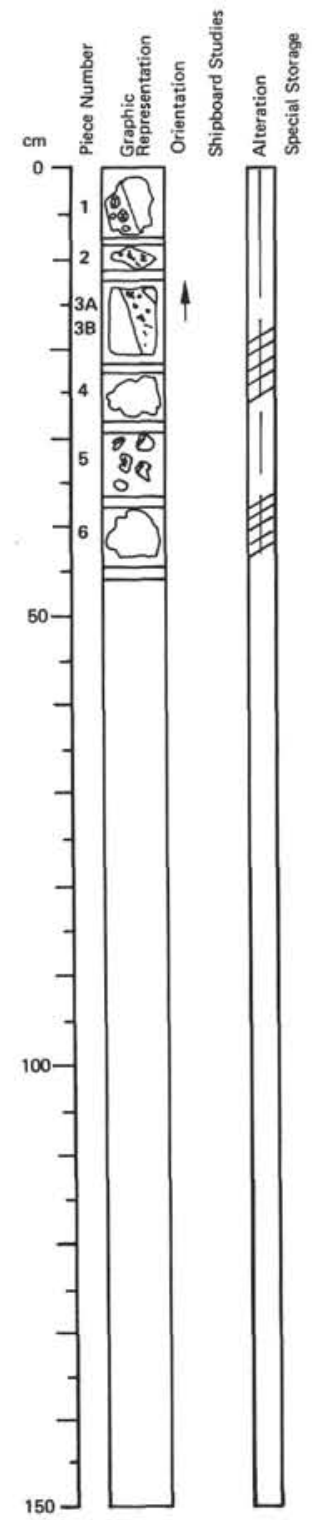

VISUAL CORE DESCRIPTION FOR IGNEOUS ROCKS

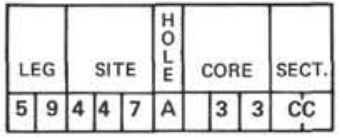

Depth: 261.5 to $261.9 \mathrm{~cm}$

Visual Description

Plagioclase-Olivine-spinel-phyric tholeitic basalt as in Section 32-3. Glassy margins brec ciated.

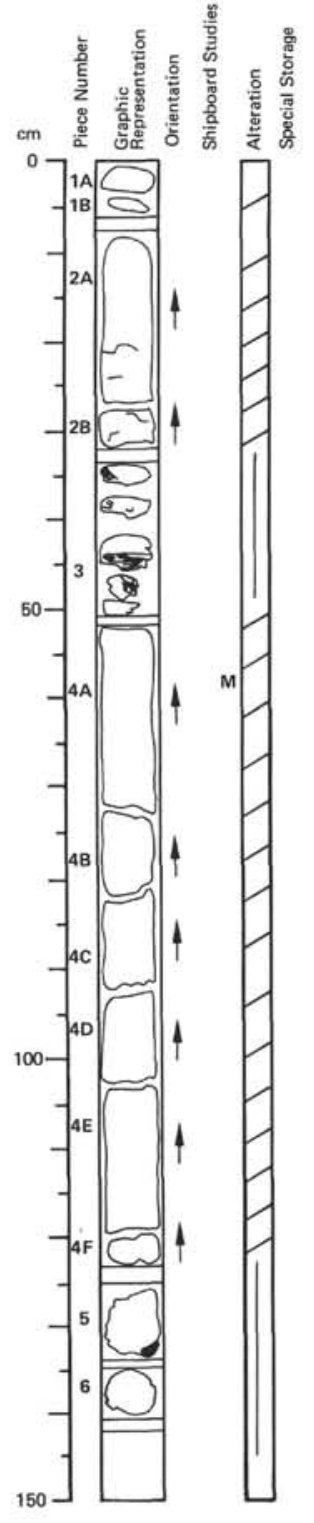

VISUAL CORE DESCRIPTION

FOR IGNEOUS ROCKS

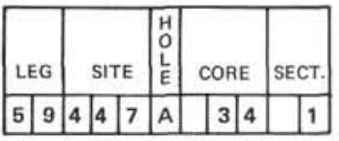

Depth: 270.5 to $272.0 \mathrm{~m}$

Visual Description

政

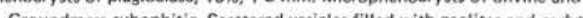
also present in thin, $0.5 \mathrm{~mm}$ veins. Patches of rock highly altered 

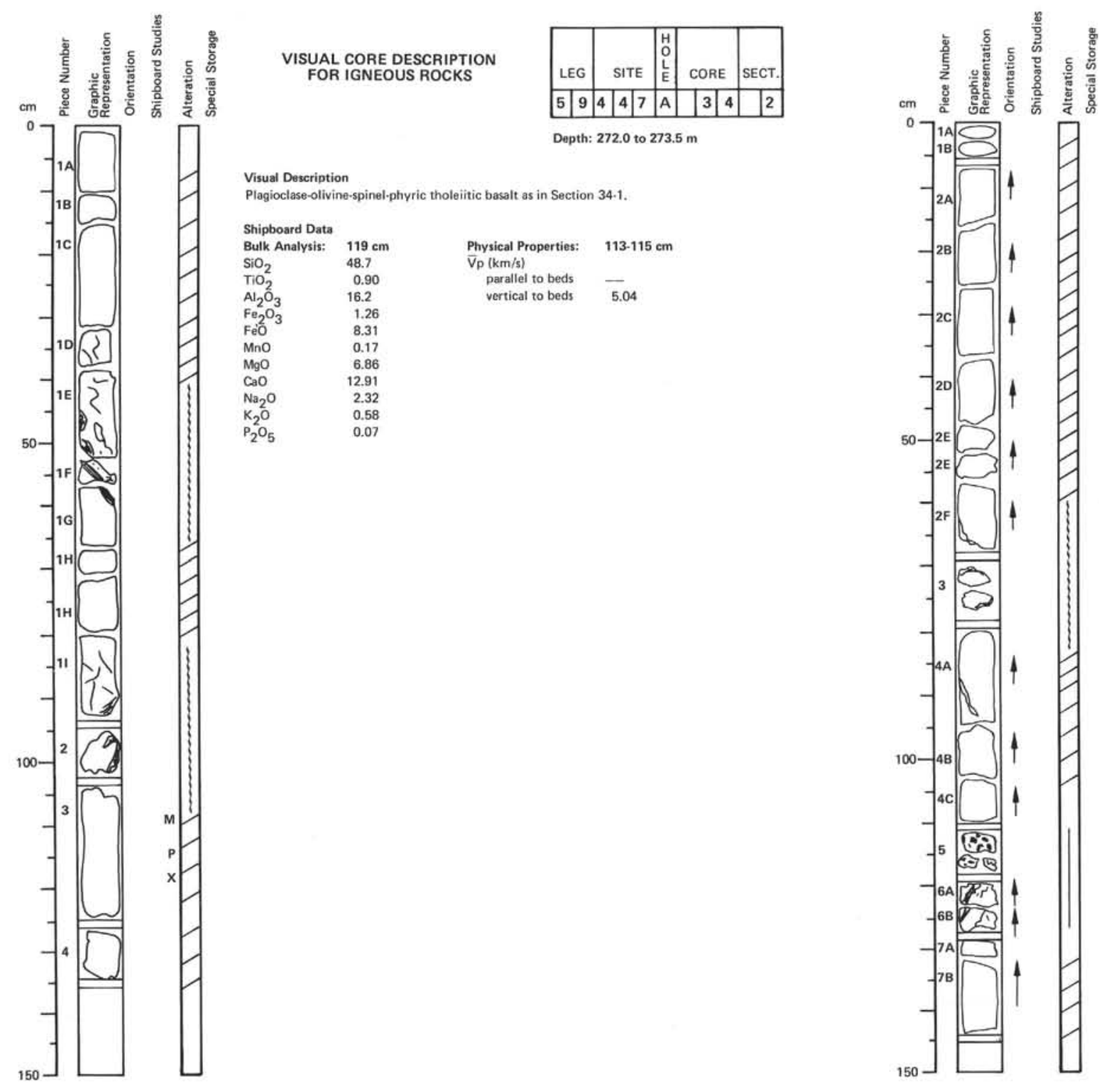

VISUAL CORE DESCRIPTION
FOR IGNEOUS ROCKS

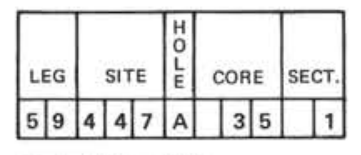

Visual Description

Plagioclasse-olivine-spinel-phyric tholeitic basolt as in Section 34-2. Inner parts of

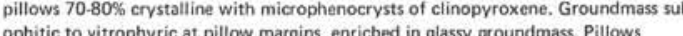
aterne vist ans alternately enriched in olivine and plagioclase phenocrysts. 

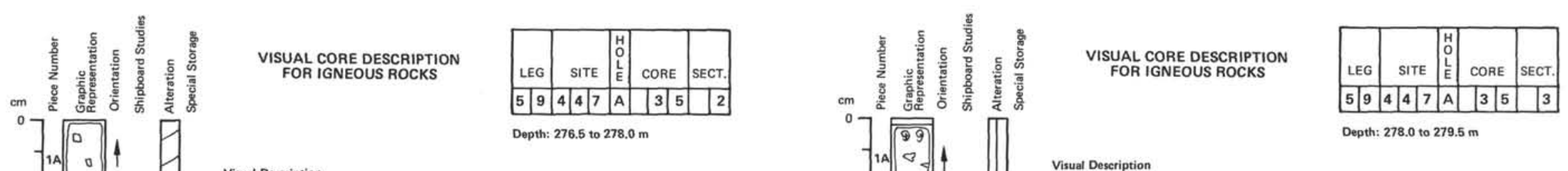

Visual Description
Plagioclase-olivine-spinel-phyric tholeitic basalt as in Section 35-1. Plagioclase phenocrysts

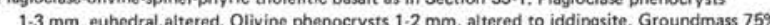

Thin Section Description

Location: $66-68 \mathrm{~cm}$, pillow interior

roundmass

. $10 \%$, An $76: 1.3 \mathrm{~mm}$, euhedral, highly altered; olivine $50 \%$.

$0.02 \mathrm{~mm}$, platminese segregations; ofivine $15 \%, 0.1-0.2 \mathrm{~mm}$, irregular, completely

Vesides, mognethe/limenite $5 \%,<0.01$; glass $2-3 \%$, altered completely.

Alteration: carbonate veins $5 \%$; clays, zeolites replacing olivine, plagioclase glass

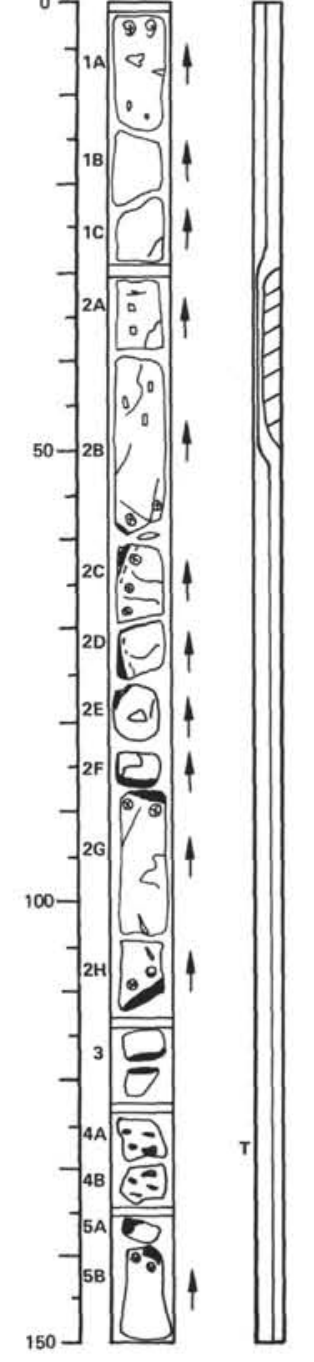

(in Section 35-2. Slight brecciation $90-150 \mathrm{~cm}$. Pieces 4A, B, altered glass breccia. 

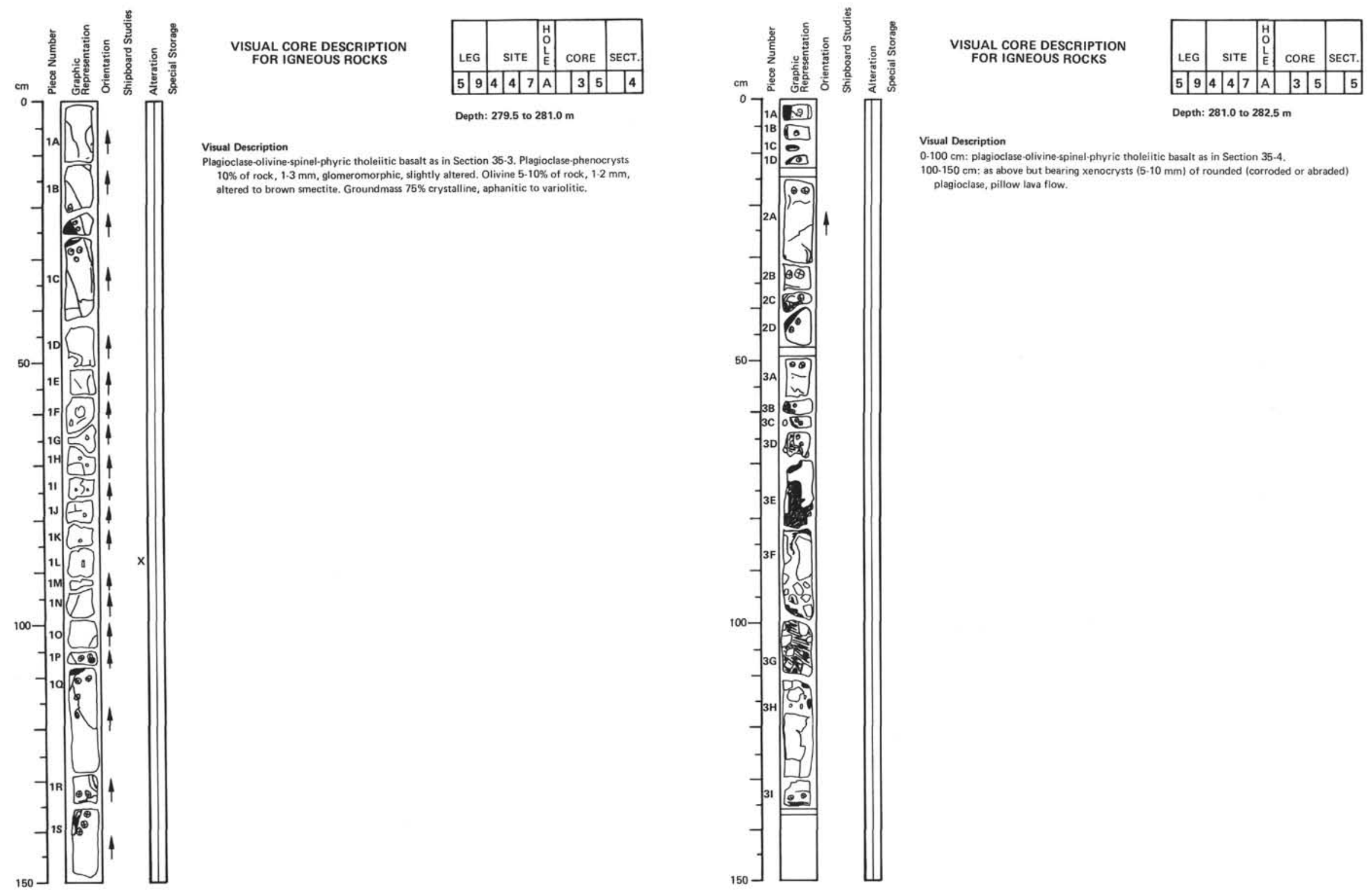


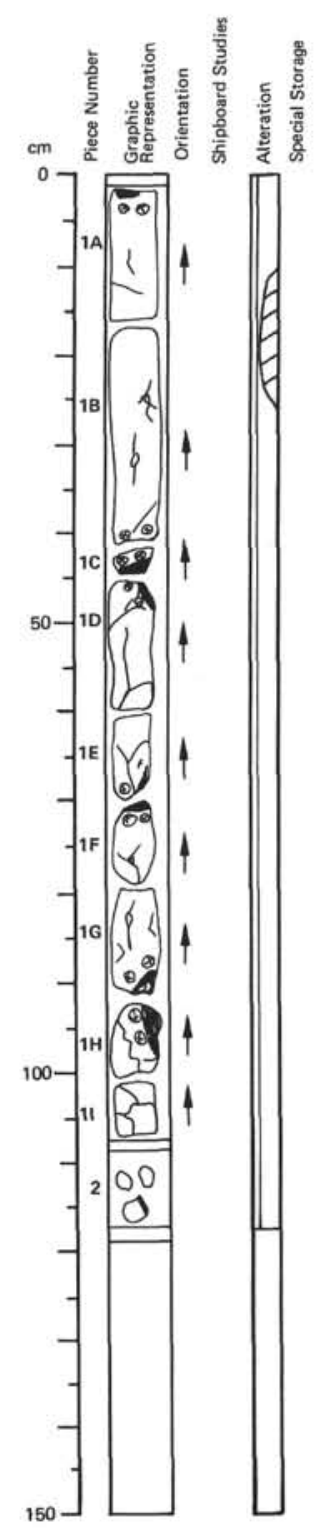

VISUAL CORE DESCRIPTION FOR IGNEOUS ROCKS

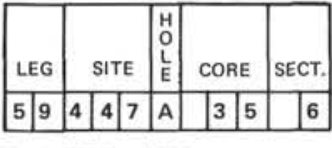

Visual Description

tholeititic basalt, bearing plagioclase xenocrysts as in lower part of Section 35-5.

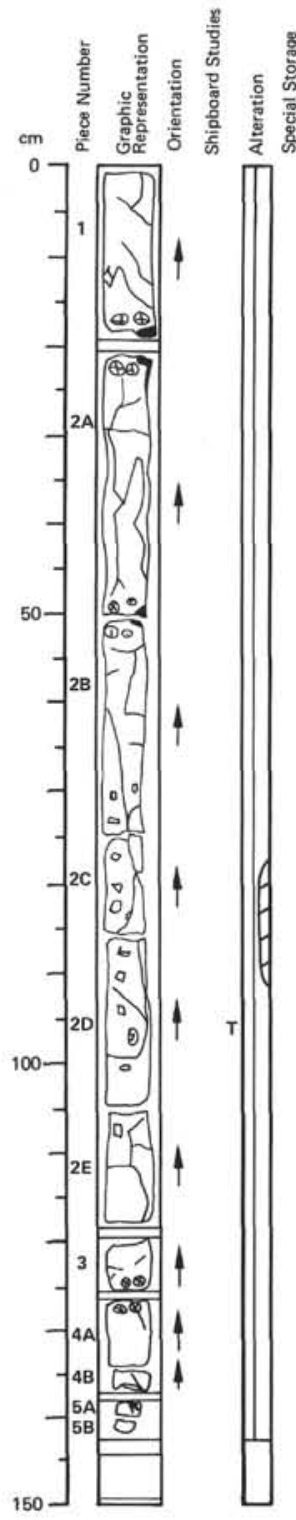

VISUAL CORE DESCRIPTION FOR IGNEOUS ROCKS

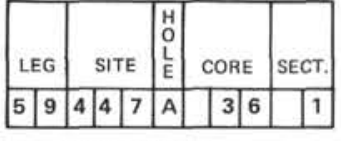

Visual Description

ing plegiocse (in interyal $20.120 \mathrm{~cm}$ they are up to $1 \mathrm{~cm}$ diameterl. Thin Section Deserimion

Location: $95-97 \mathrm{~cm}$

Texture: porphyritic with sut

Phenocrysts: 6.8\%; plagioclase $80.00 \%, 1.2 \mathrm{~mm}$, orhet r. $10.20 \%, 1.2 \mathrm{~mm}$, anhedrai, pseudomorphs, spinel, rare, $0.2 \mathrm{~mm}$, euhedral, as inclusic (1)

(a) $50 \%, 08 \mathrm{~mm}$, elongate laths; clinopyroxene $40 \%$ tions, magnetite/ilmenite $4 \%,<0.01 \mathrm{~mm}$; glass 6 

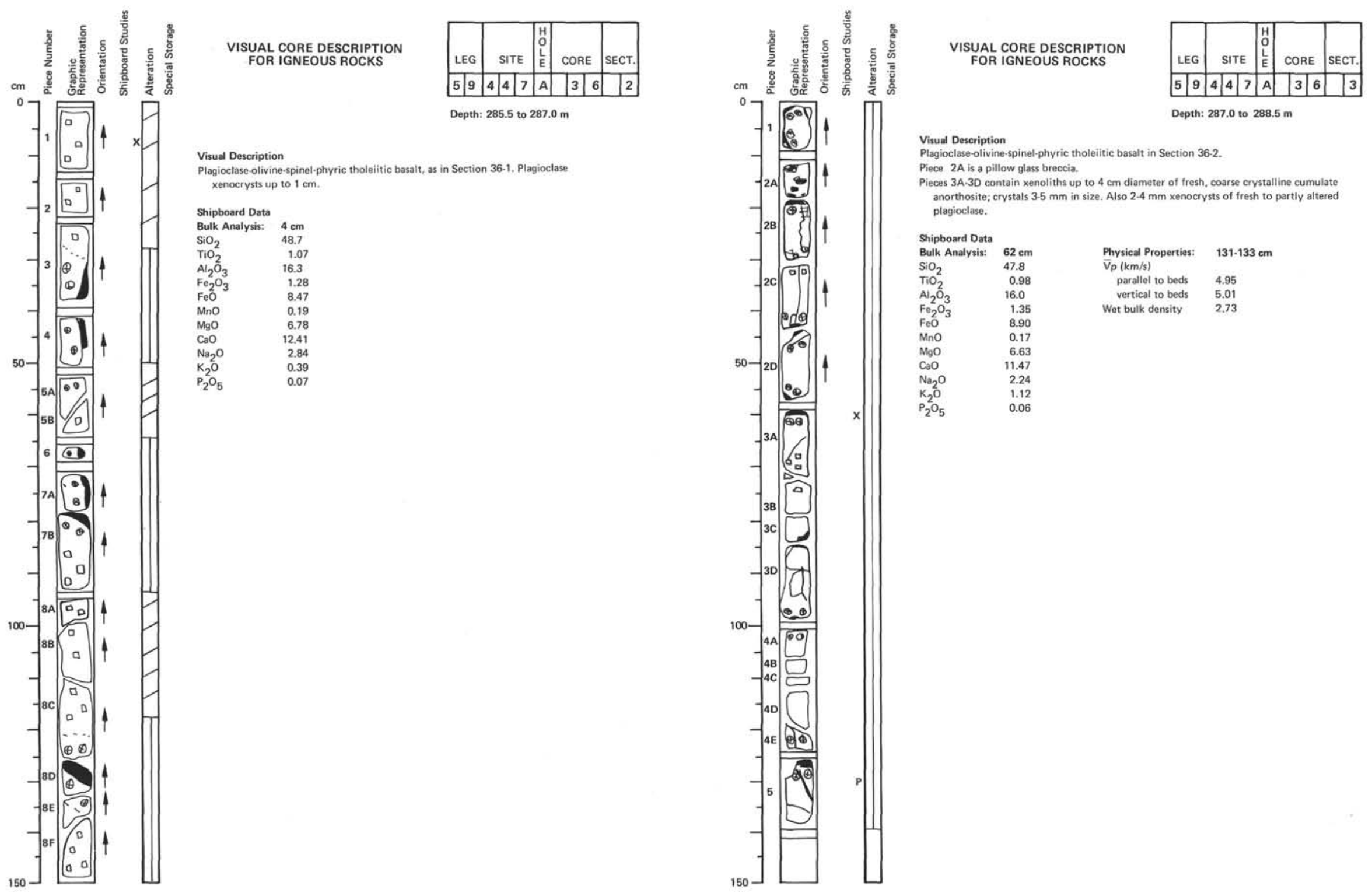

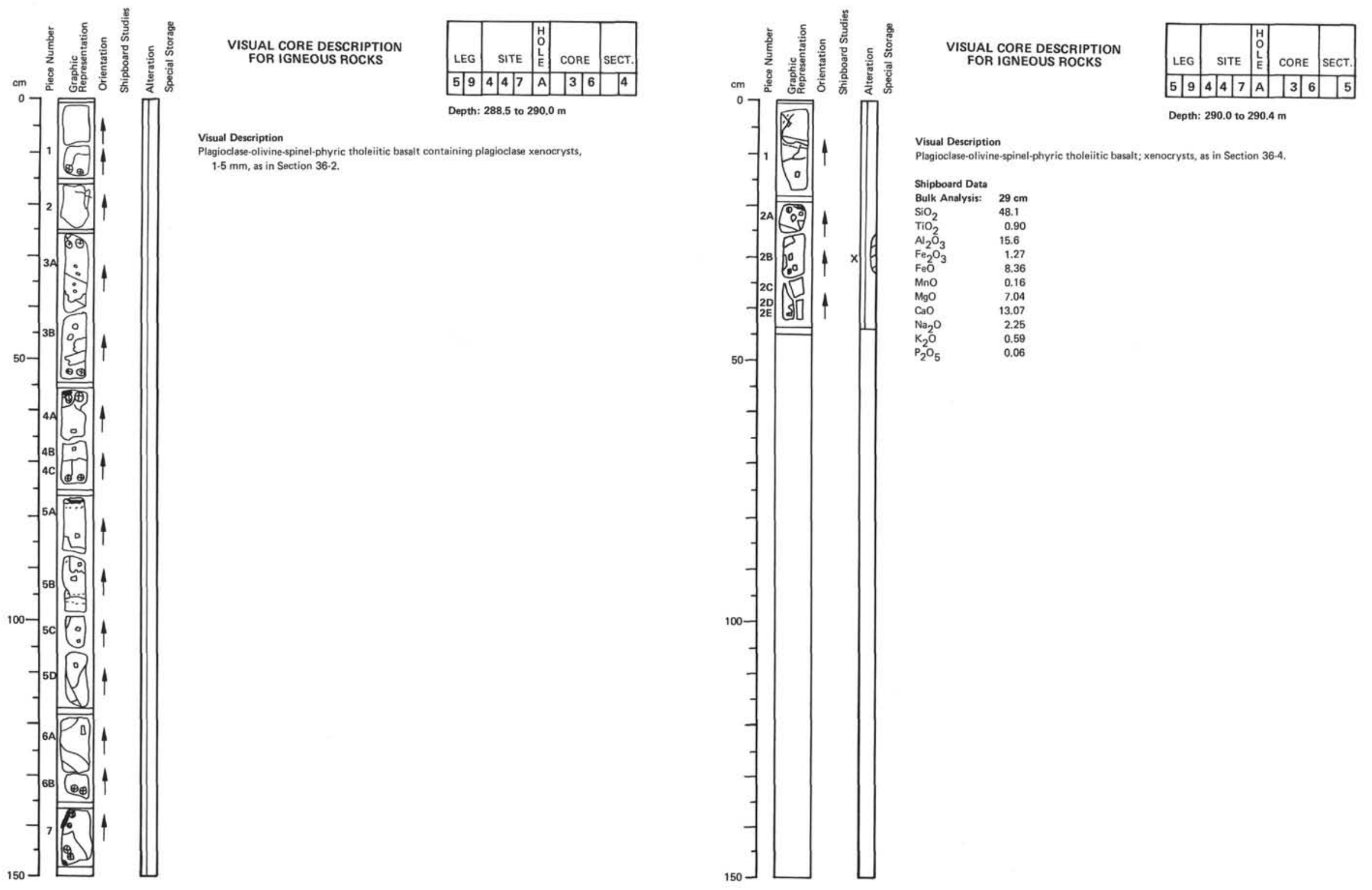


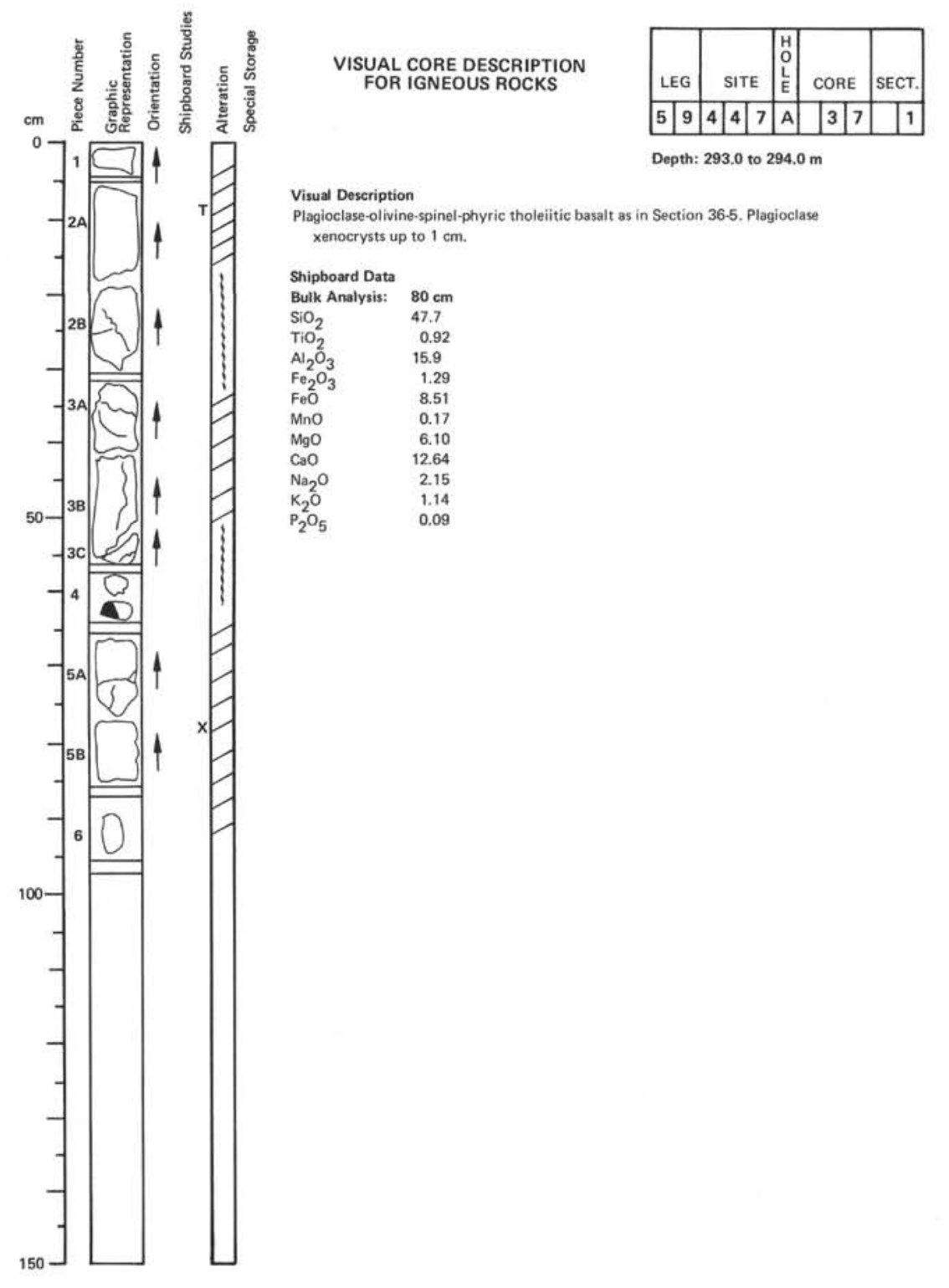




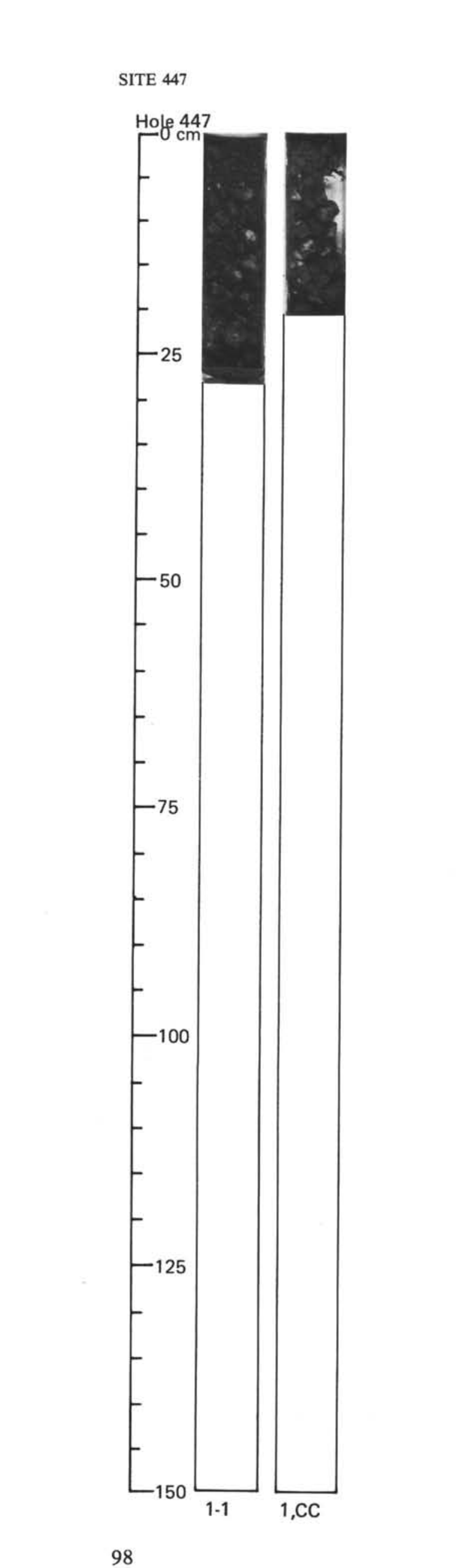


Hole 447A

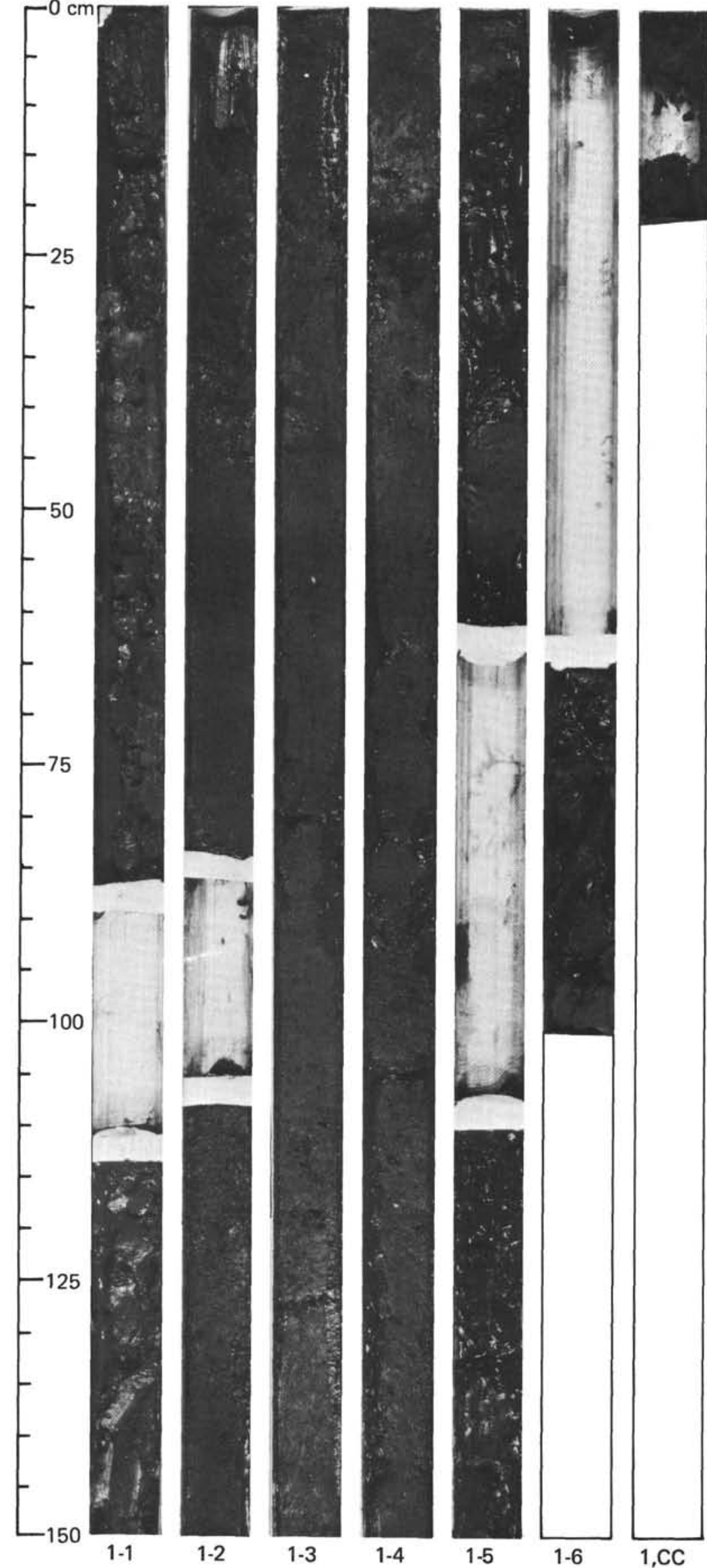

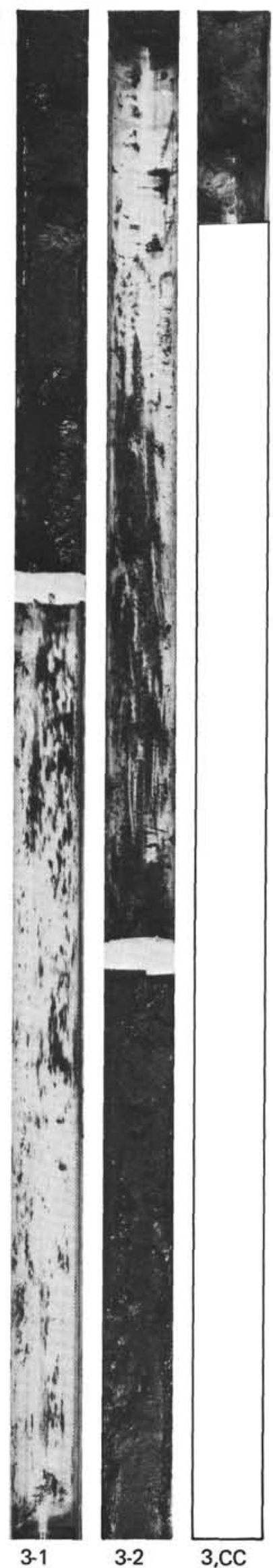

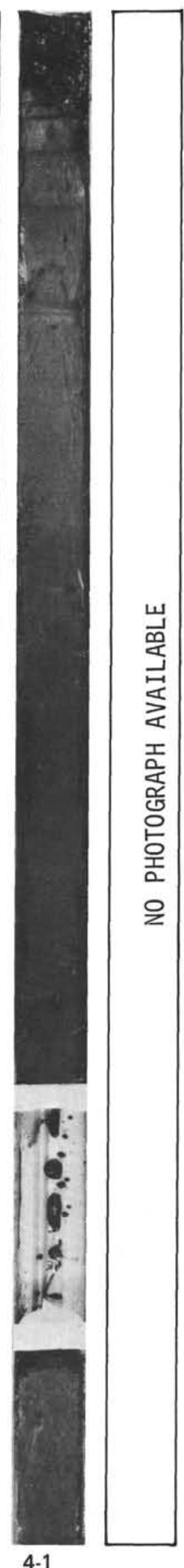


SITE 447

Hole 447 A

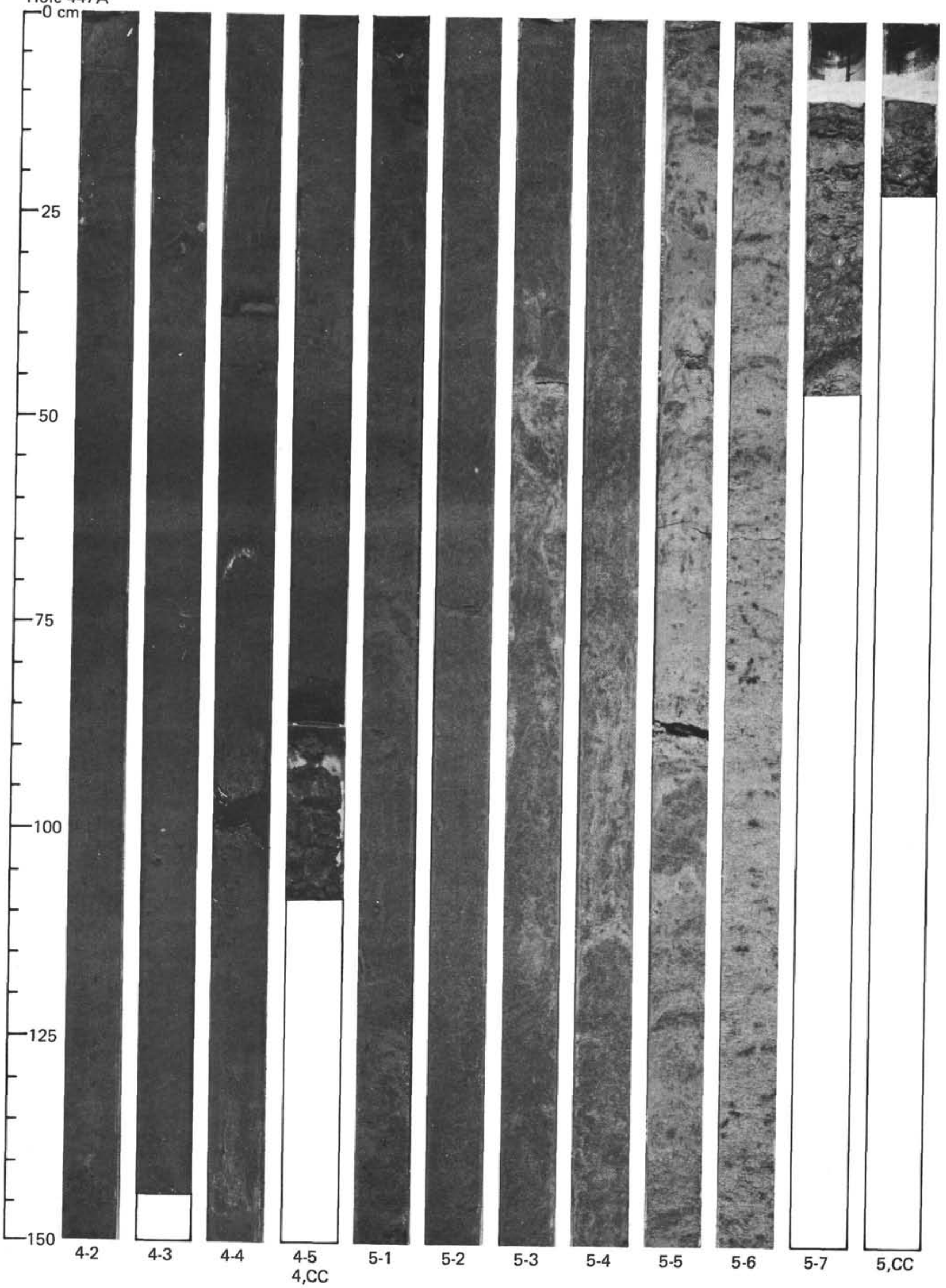


Hole 447A

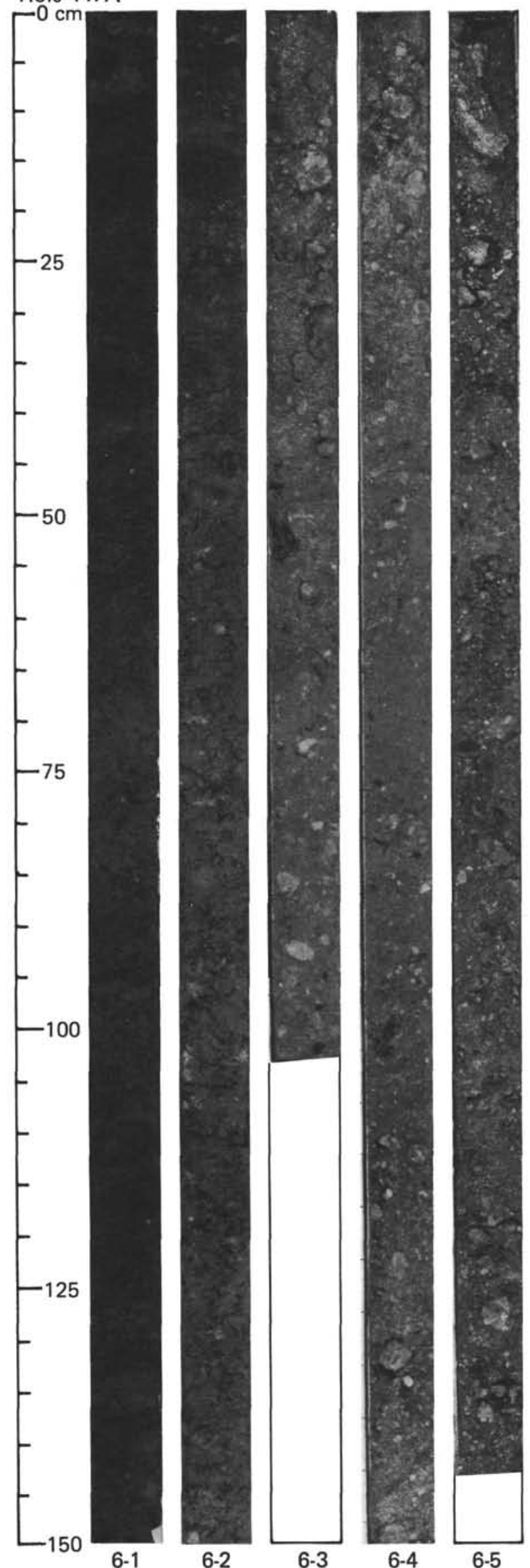

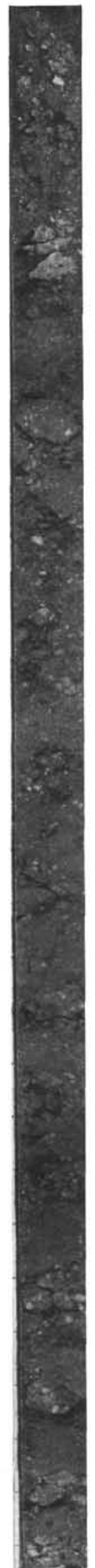

6-6
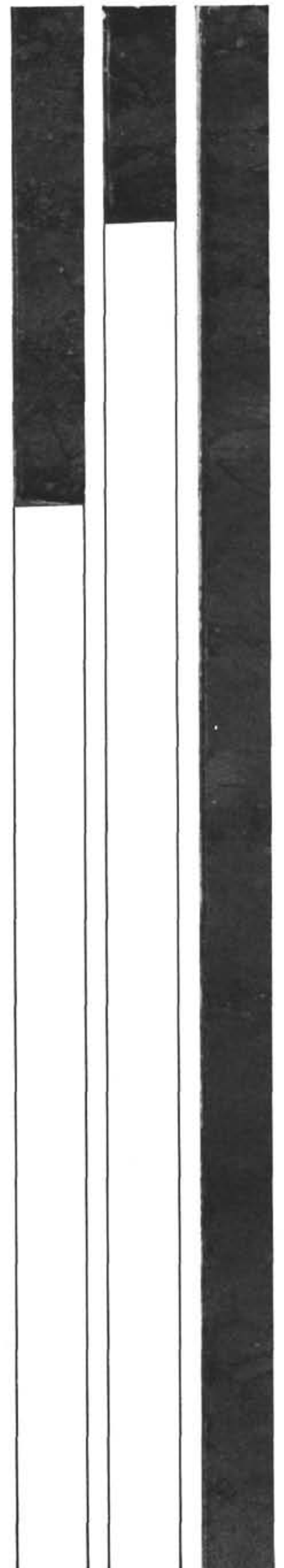

$6, \mathrm{CC}$

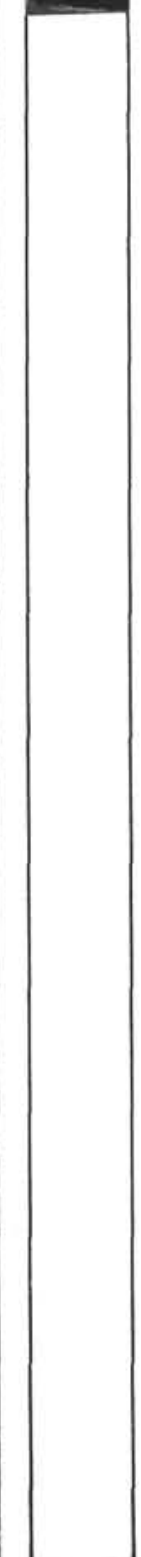

6-7

7-1

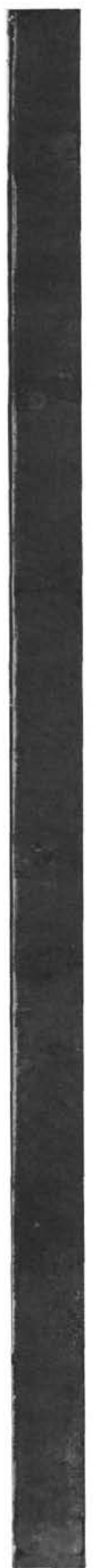

7-2
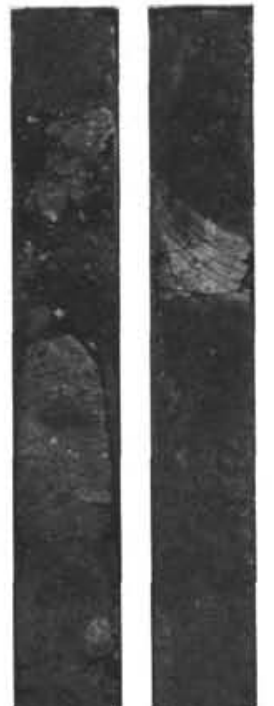

7-3 
SITE 447

Hole 447A

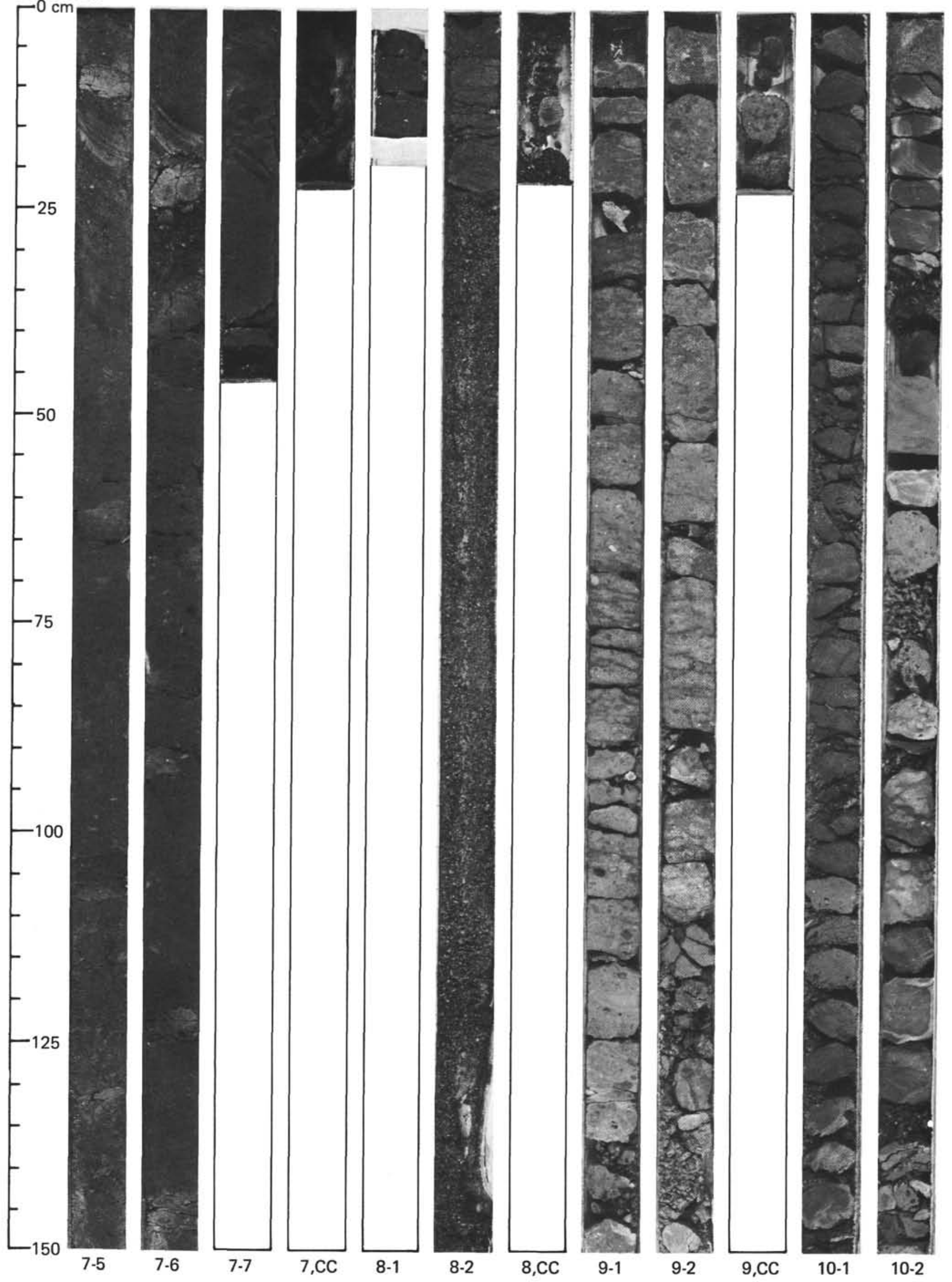


Hole 447A

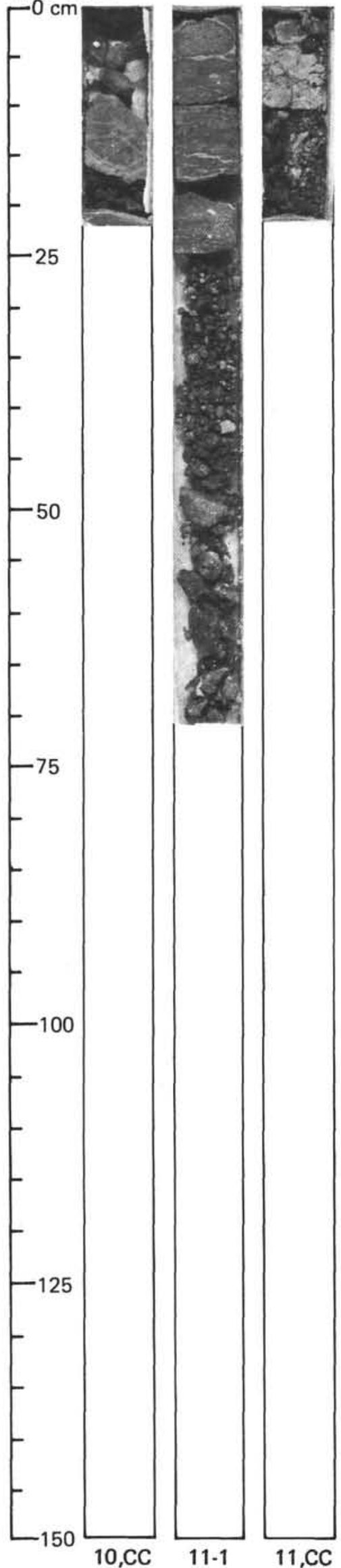

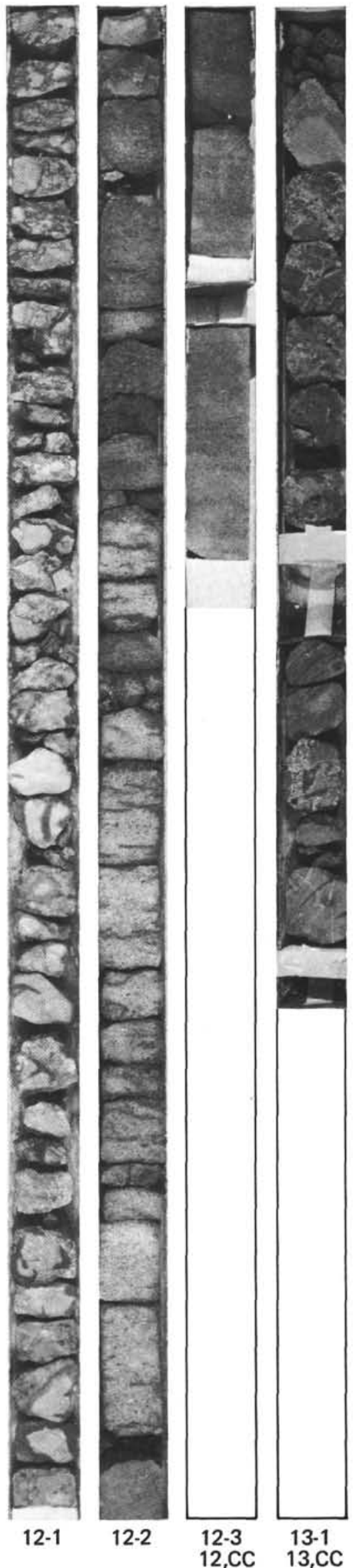
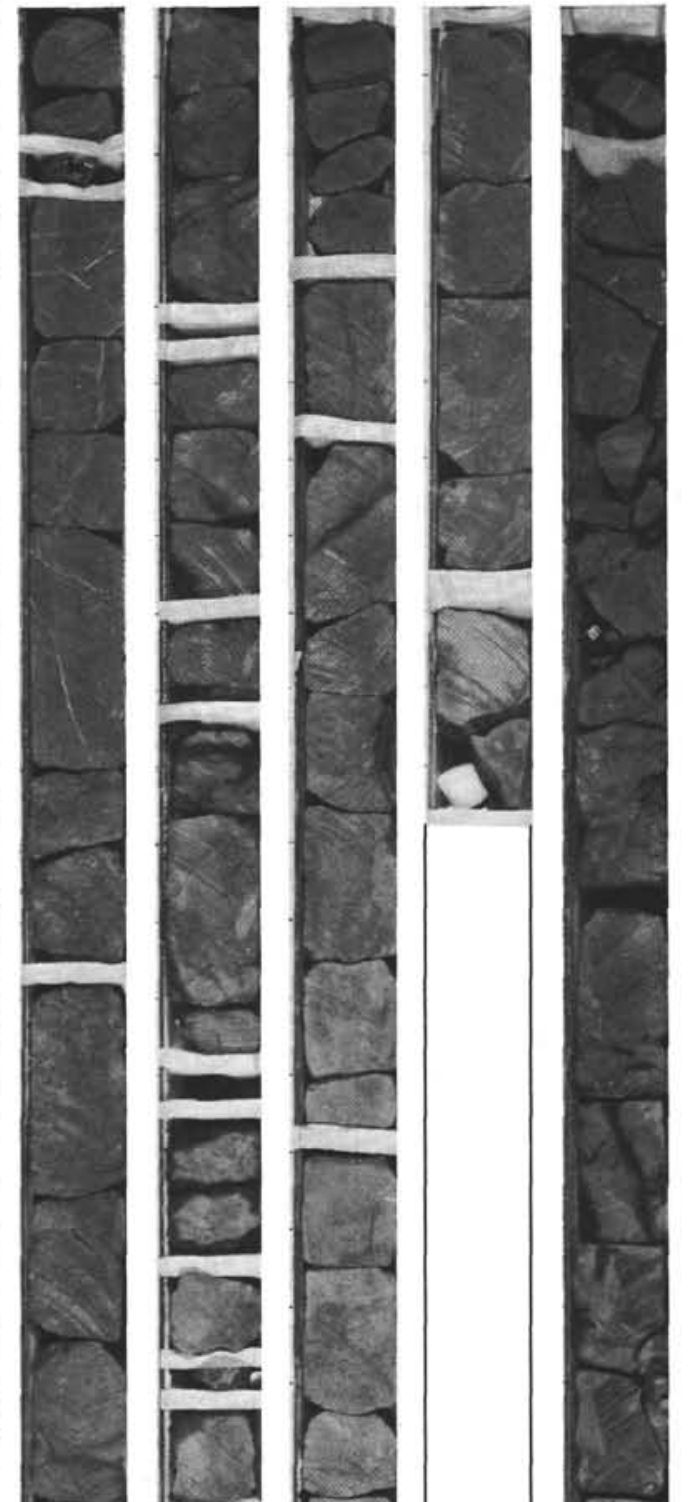

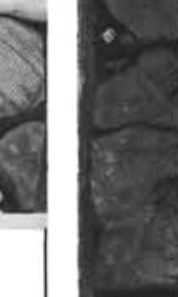

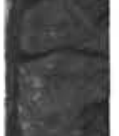




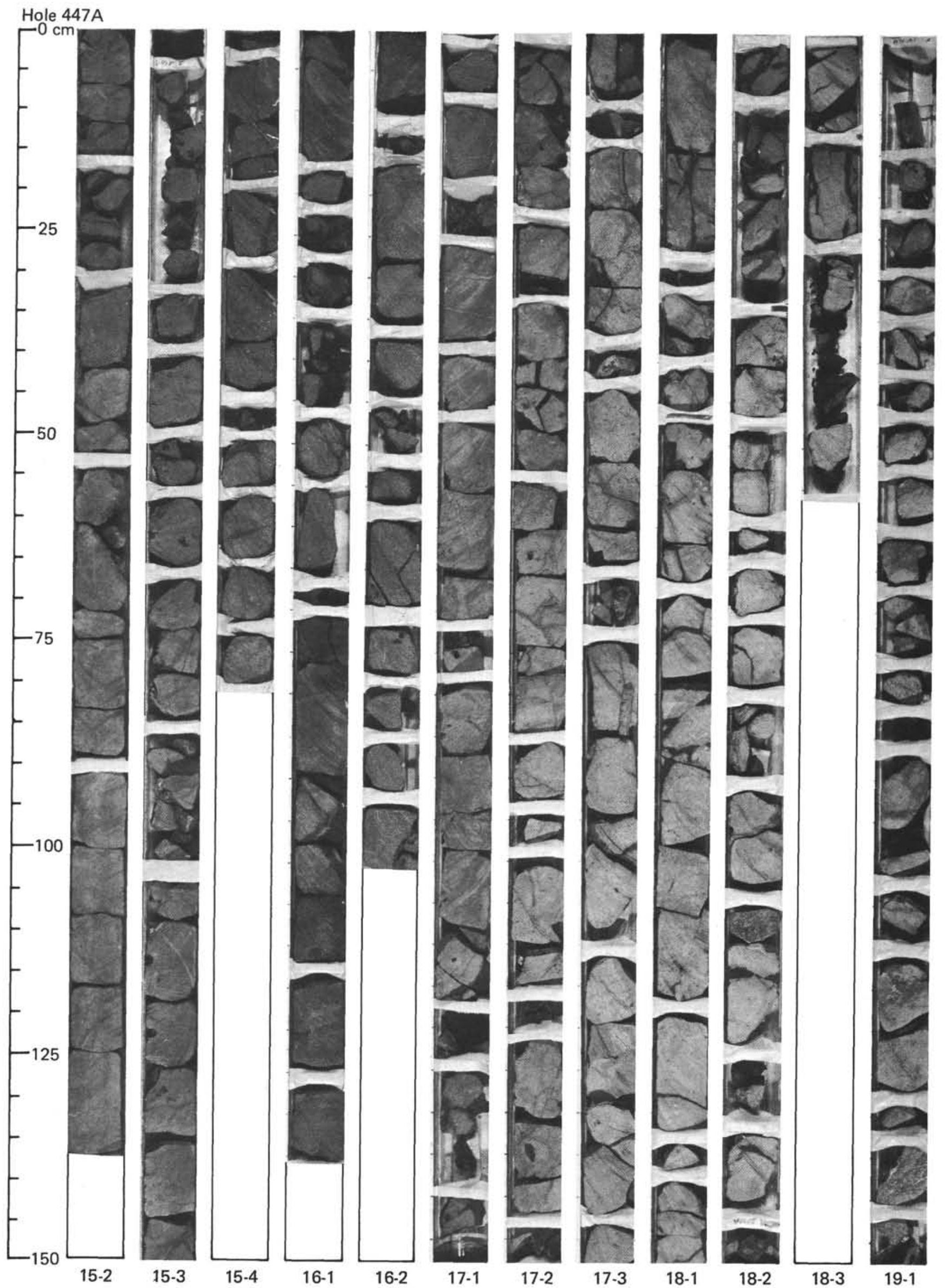


Hole 447A

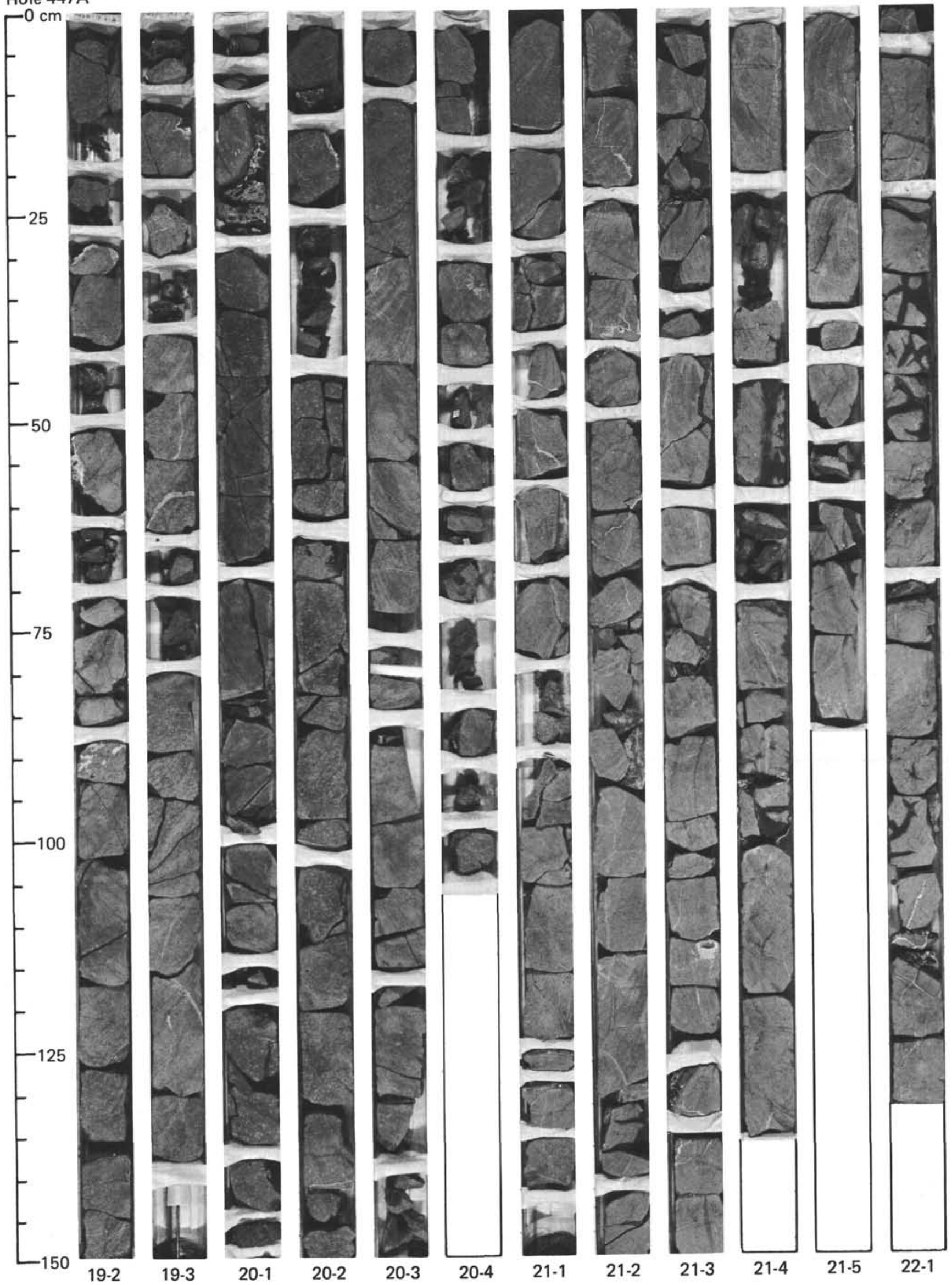


Hole 447A

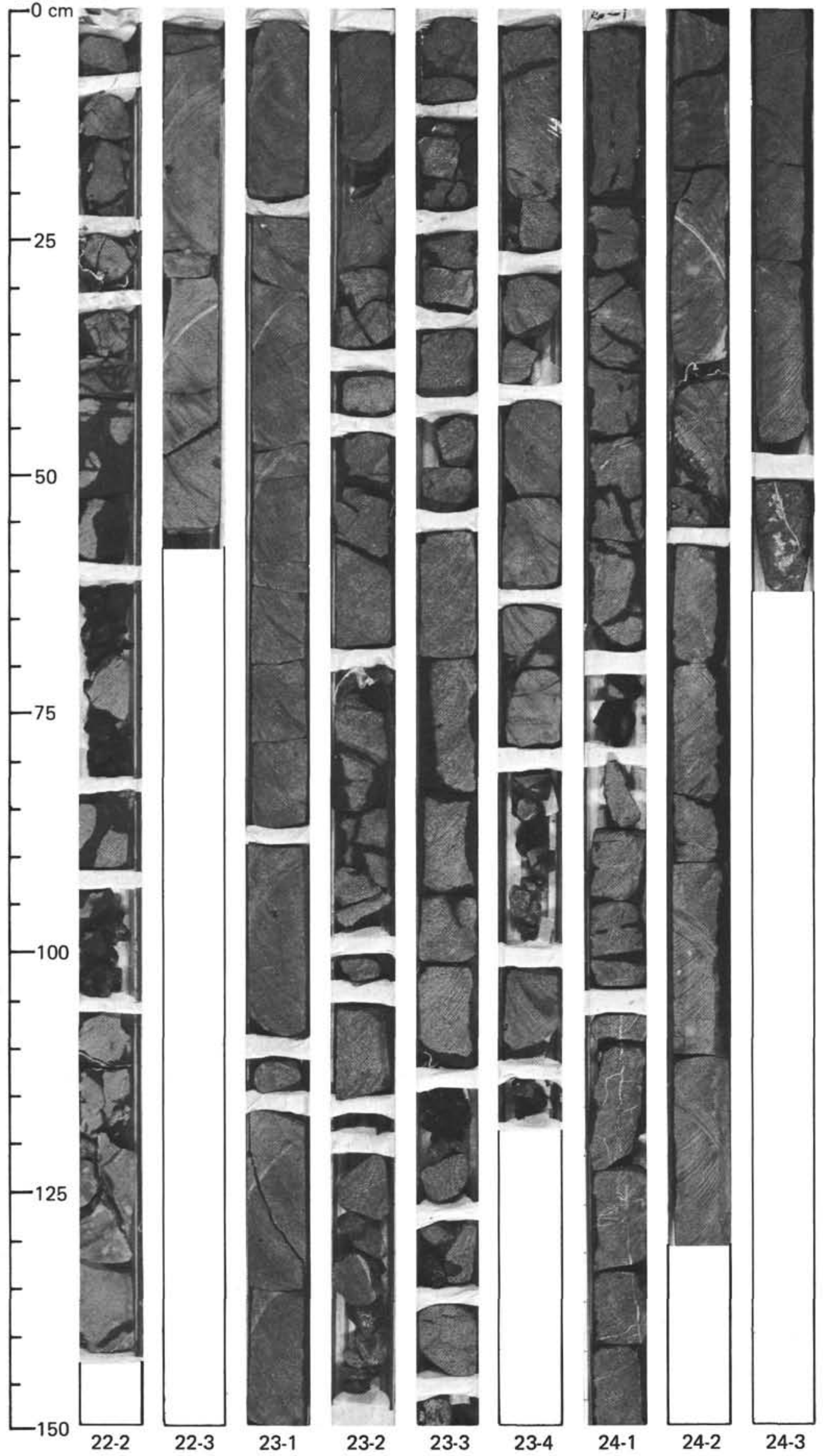

23-1

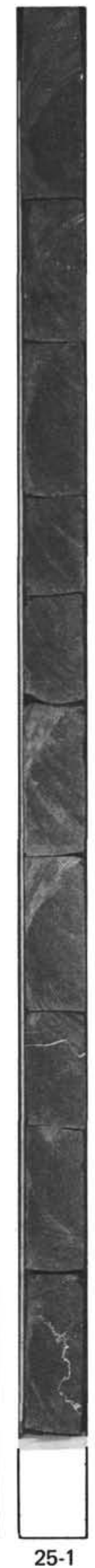

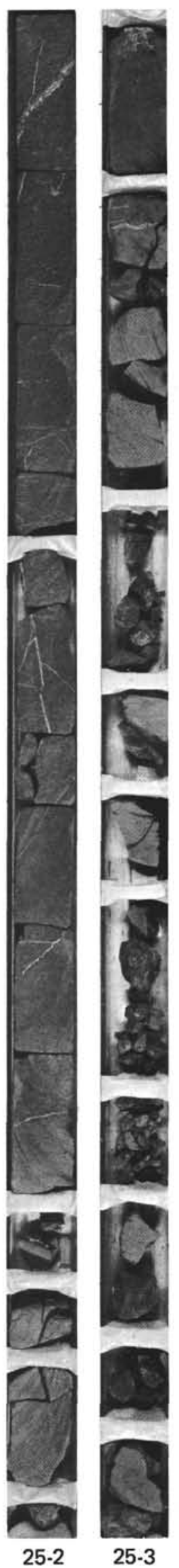


Hole 447A

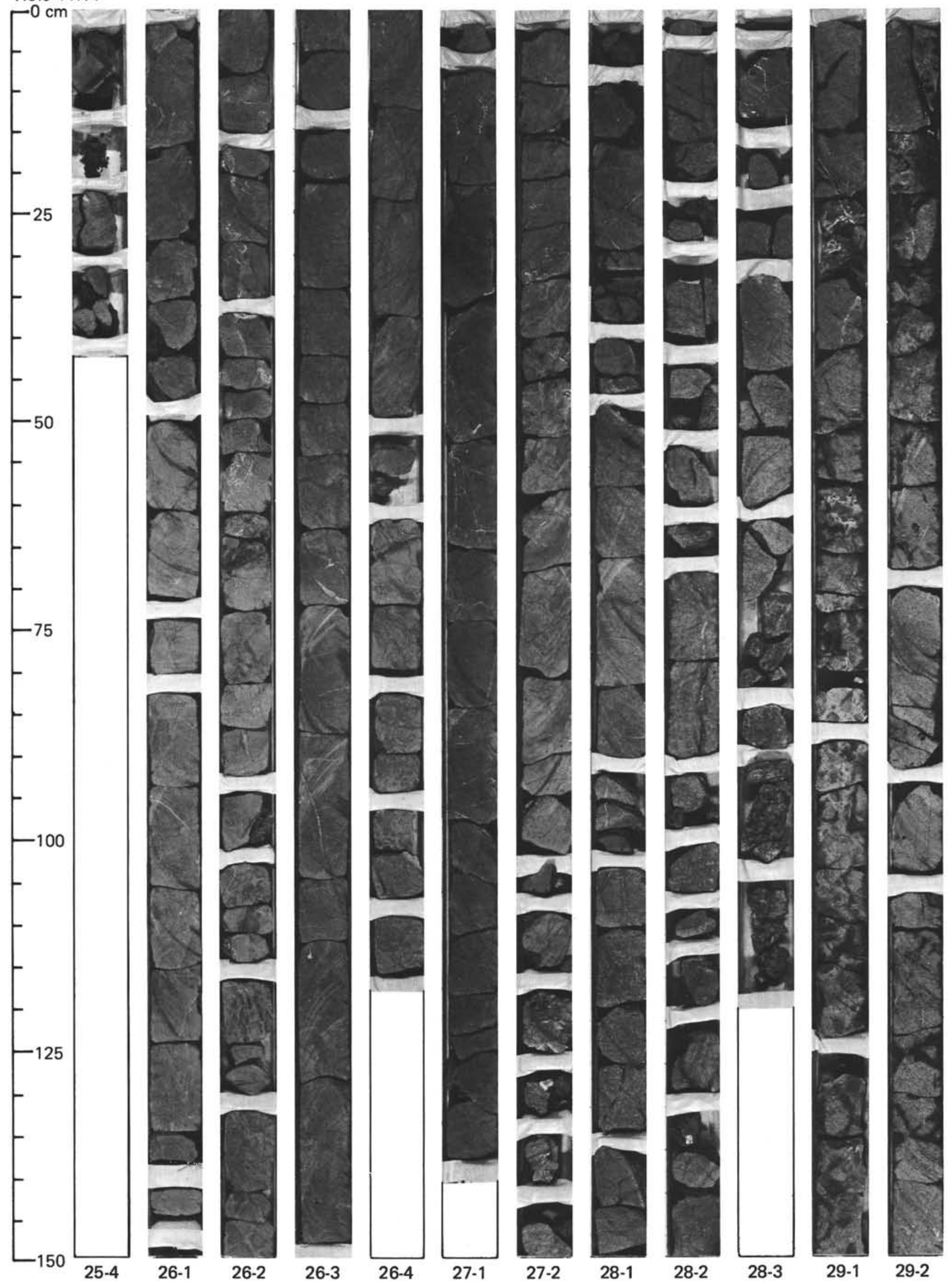


Hole 447A

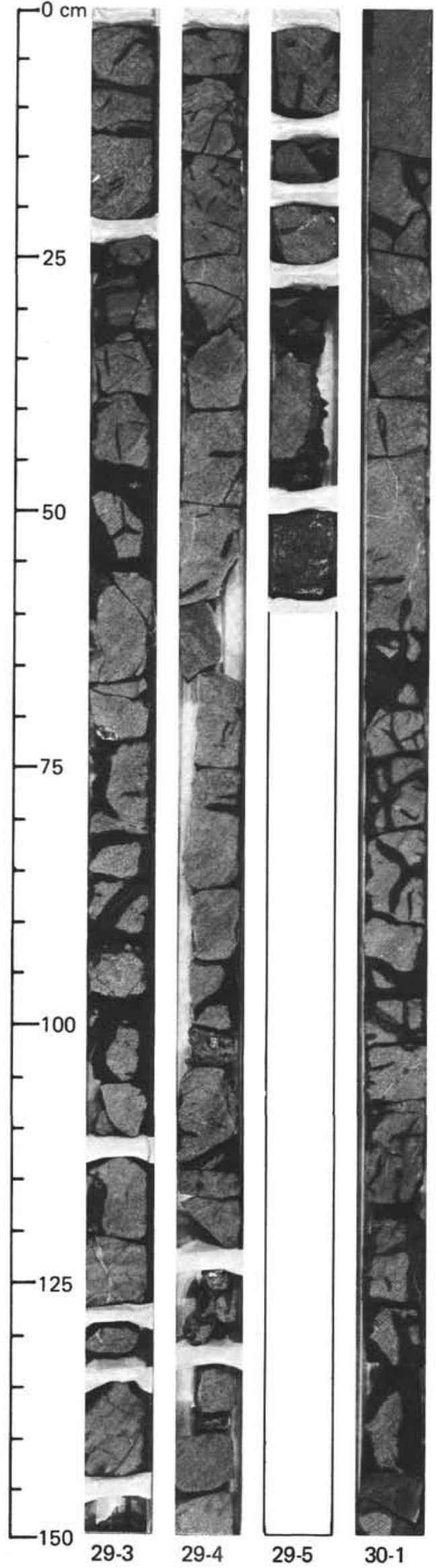

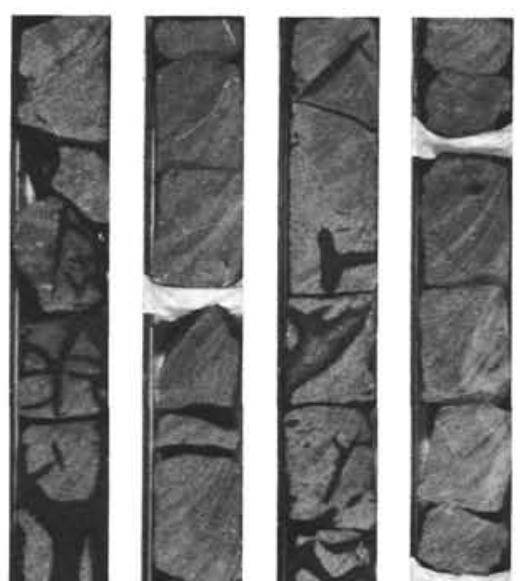
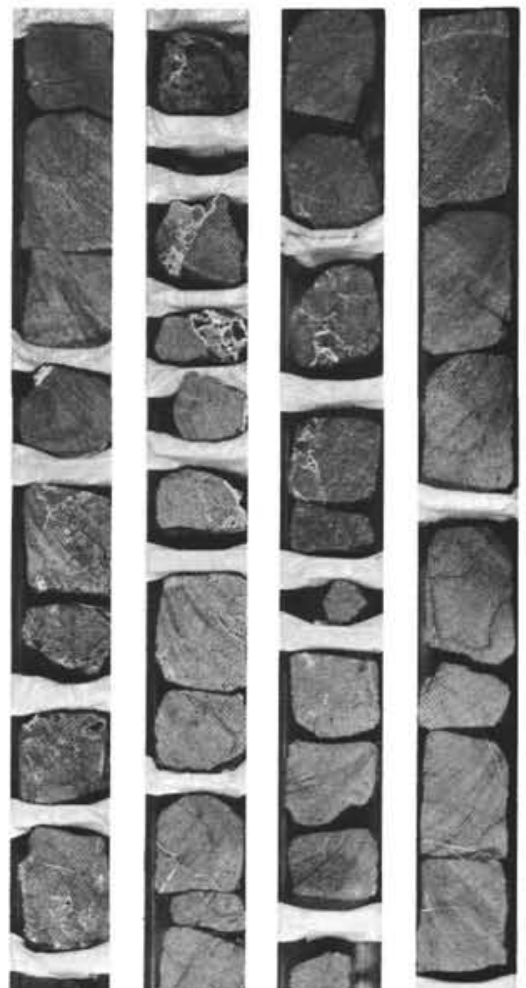

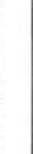
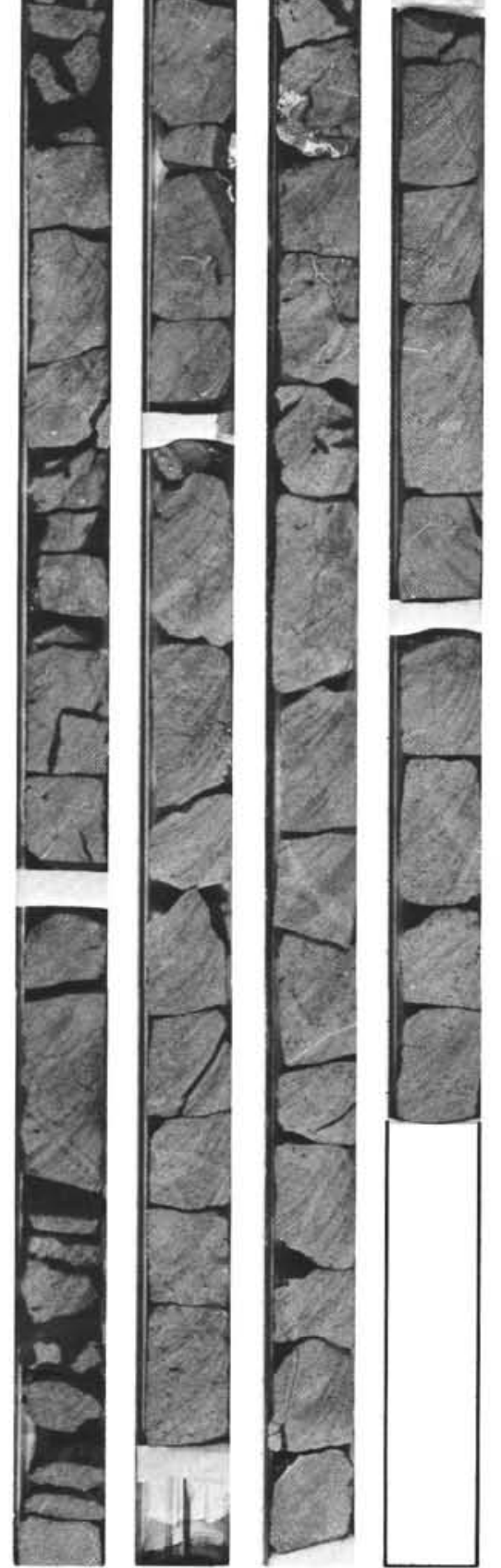

30-2

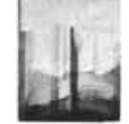

30-3

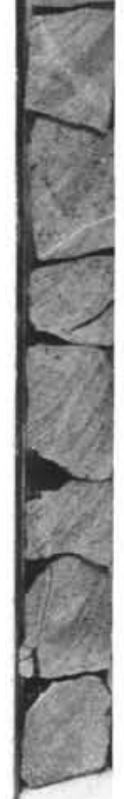

$30-4$
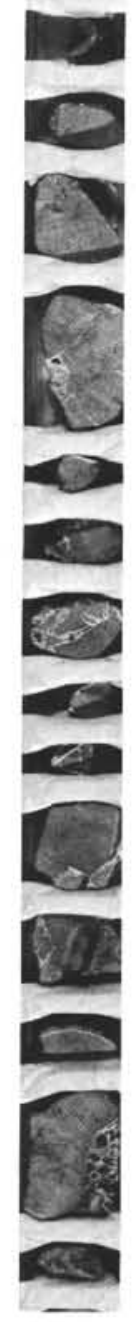

31-1
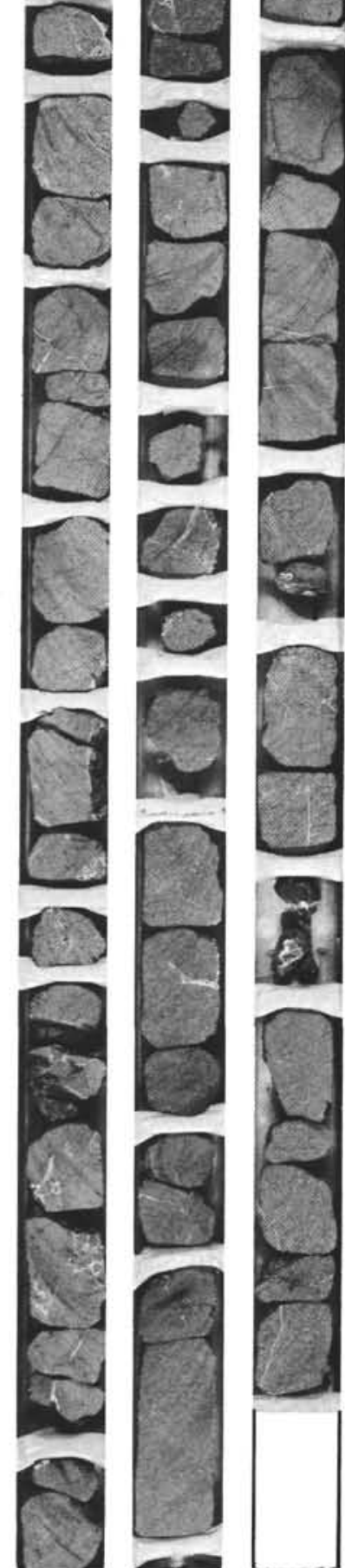

31-2

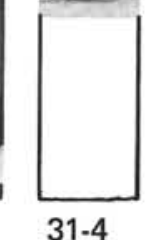


Hole 447A

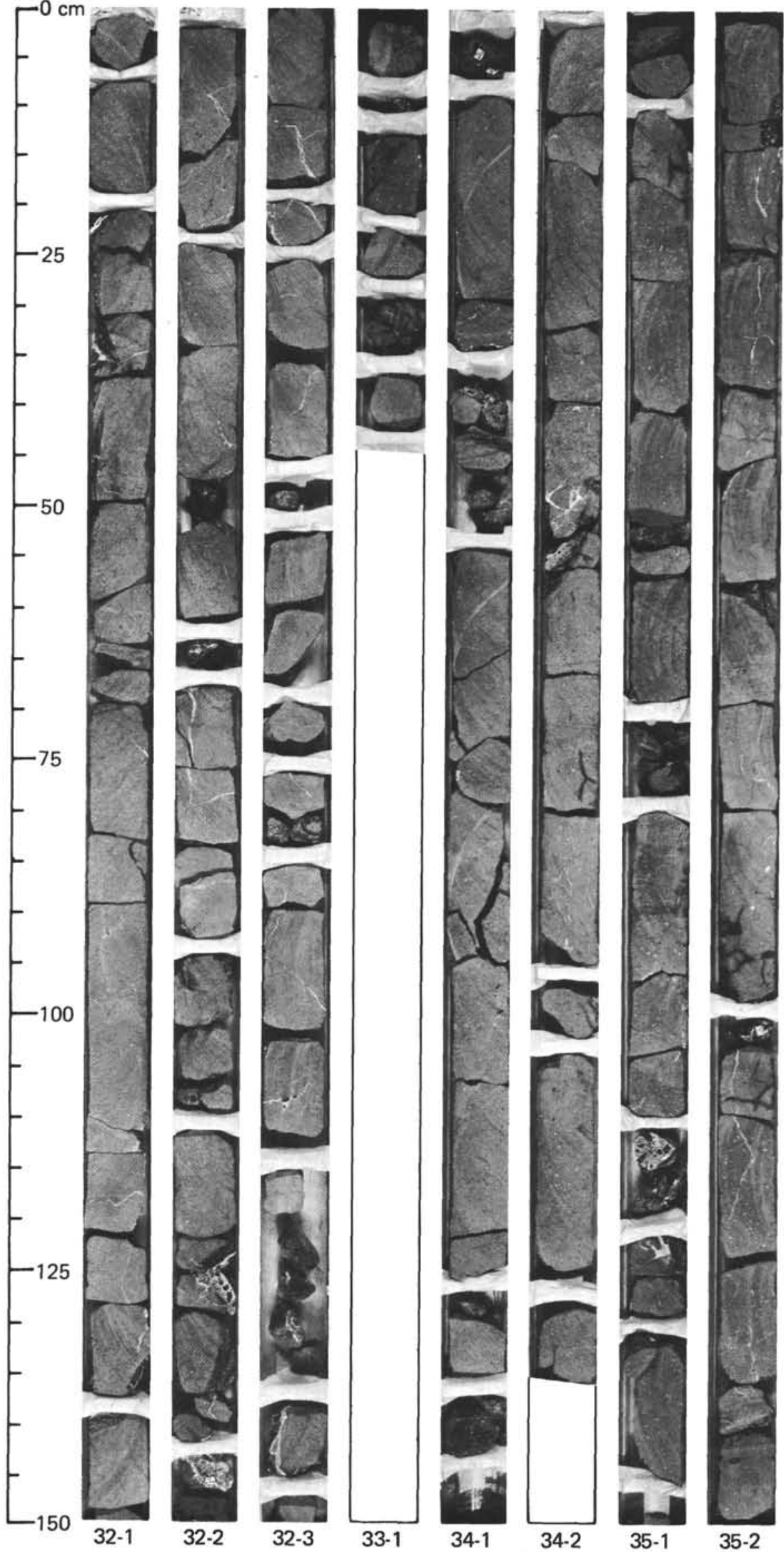

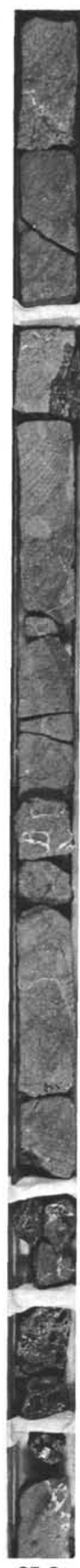

35-3

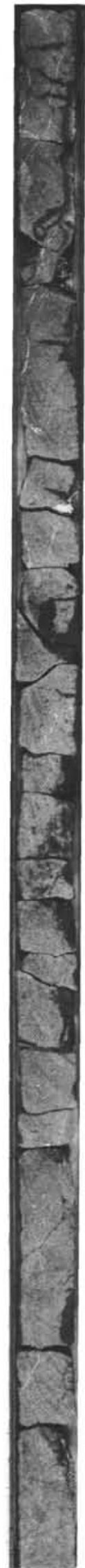

35-4
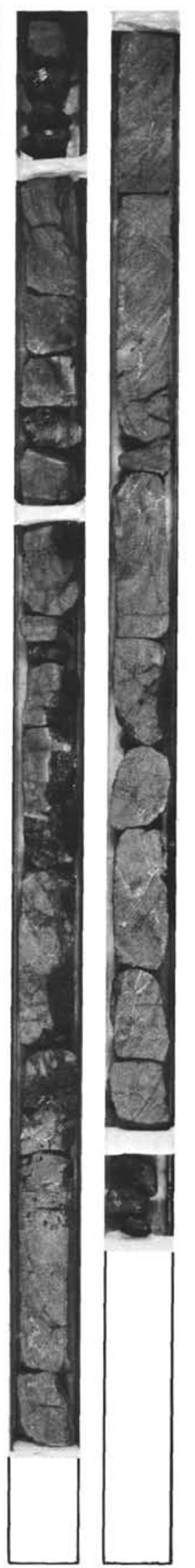

35-5
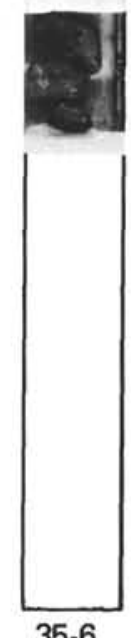
SITE 447

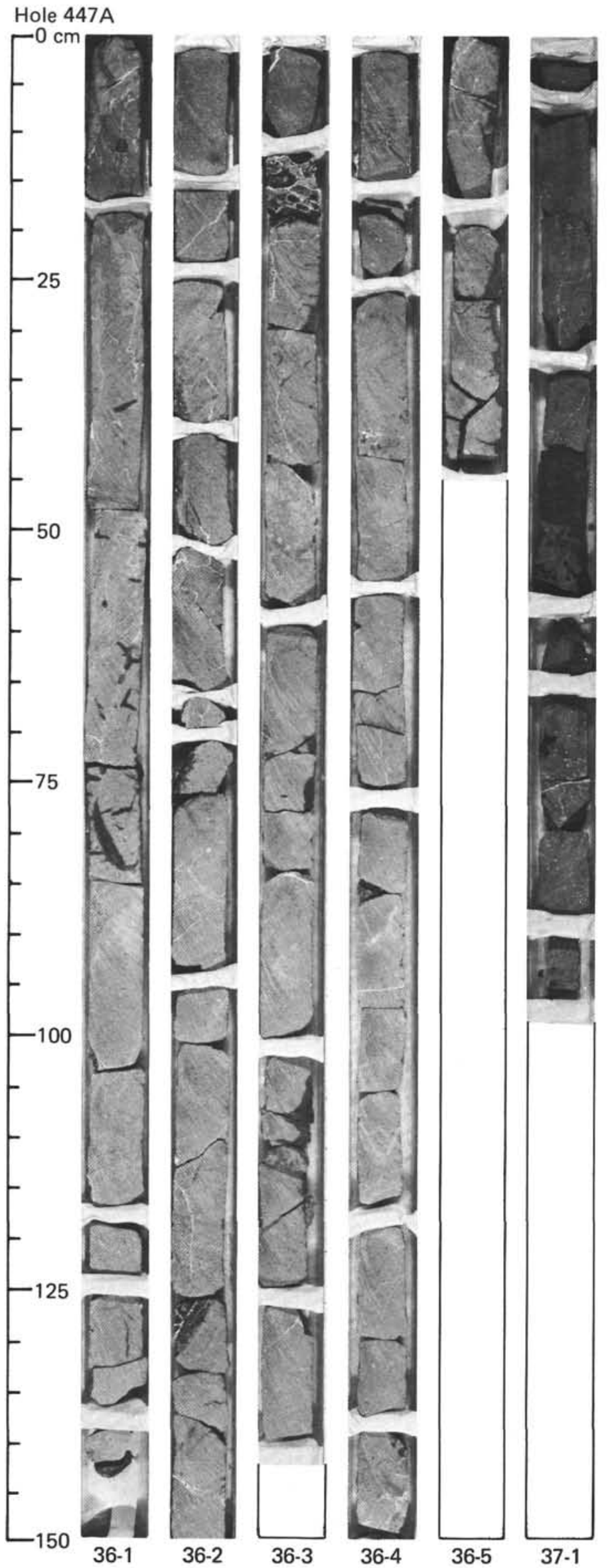

